UNIVERSIDADE DE SÃO PAULO

ESCOLA DE COMUNICAÇÕES E ARTES

PROGRAMA DE PÓS-GRADUAÇÃO EM CIÊNCIAS DA COMUNICAÇÃO

CARLOS AUGUSTO TAVARES JUNIOR

Rio 2016: o Jornalismo Esportivo e o Comitê Olímpico do Brasil 
CARLOS AUGUSTO TAVARES JUNIOR

\section{Rio 2016: o Jornalismo Esportivo e o Comitê Olímpico do Brasil}

\section{Versão original}

Tese apresentada ao Programa de Pós-Graduação em Ciências da Comunicação da Universidade de São Paulo para obtenção do título de Doutor em Comunicação.

Área de Concentração: Estudo dos Meios e da Produção Midiática

Orientador: Prof. Dr. Luciano Victor Barros Maluly

Coorientador: Prof. Dr. Wilton Garcia

São Paulo

2019 


\section{Autorizo a reprodução e divulgação total ou parcial deste trabalho, por qualquer meio convencional ou eletrônico, para fins de estudo e pesquisa, desde que citada a fonte.}

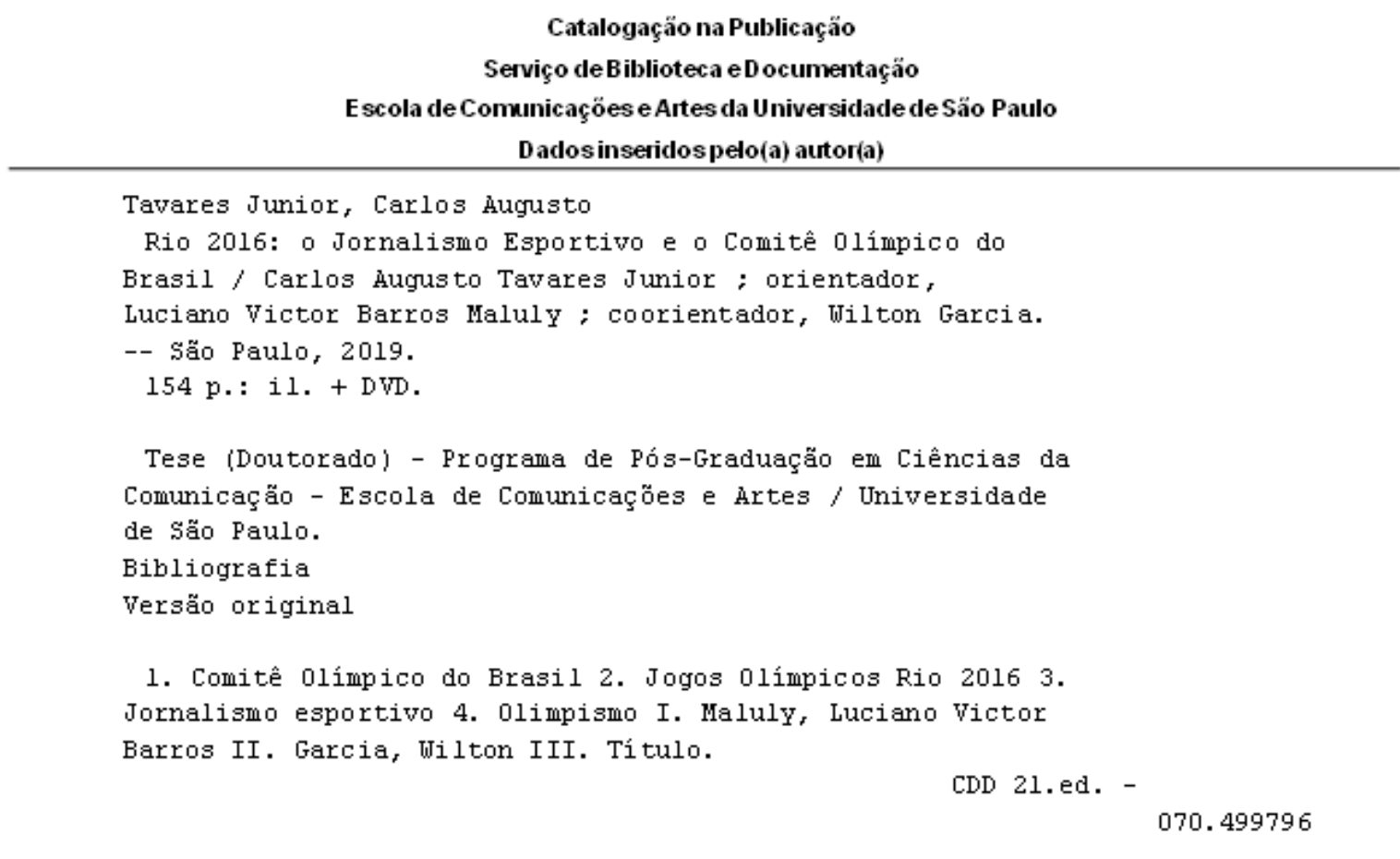

Elaborado por Sarah Lorenzon Ferreira - CRB-8/6888

Este trabalho foi realizado com apoio da Coordenação de Aperfeiçoamento de Pessoal de Nível Superior (CAPES) - Código de Financiamento 001. 
TAVARES JUNIOR, Carlos Augusto. Rio 2016: o Jornalismo Esportivo e o Comitê Olímpico do Brasil. 2019. 154 f. Tese (Doutorado em Ciências da Comunicação - Programa de Pós-Graduação em Ciências da Comunicação). São Paulo: Universidade de São Paulo, 2019.

Aprovado em:

Banca Examinadora

Prof. Dr.

Instituição:

Julgamento:

Prof. Dr.

Instituição:

Julgamento:

Prof. Dr.

Instituição:

Julgamento:

Prof. Dr.

Instituição:

Julgamento:

Prof. Dr.

Instituição:

Julgamento: 


\section{Dedicatória}

Aos meus orientadores, Prof. Dr. Luciano Victor Barros Maluly e Prof. Dr. Wilton Garcia, pelo aprendizado adquirido no desenvolvimento desta pesquisa.

Às pessoas que contribuíram diretamente com a escrita da tese: os entrevistados nas três etapas de pesquisa: Prof. Dr. Ronaldo George Helal, Prof. Dr. Manuel Carlos Chaparro, Prof. Dr. Ary Rocco Júnior, Prof. Dr. José Carlos Marques, Prof. Dr. Anderson Gurgel, Prof. João Jair Sartorelo, Eva Regina Freitas, Arthur Mário Medeiros Ramalho, Prof. Dr. Pascoal Tambucci, Prof. Dr. Carlos Toural Bran, Daniel Vieira da Silva, Carlos Flórido, Carlos Miguel Machado, Pedro Jorge da Cunha, Fernando Eurico, António Varela, João Malha, Geraldo Armando Cardoso Neto, José Ricardo Campos Leite, Fábio França, Fernando Saraiva, Victor Ramalho, Rafael Bullara, Nathália Ely Silveira, Marcus Von Groll, Vitor Prates e Prof. Dr. Sérgio Settani Giglio.

Aos professores da Universidade Federal do Mato Grosso do Sul: Prof. ${ }^{a}$ Dr$^{\mathrm{a}}$. Daniela Cristiane Ota, Prof. Dr. Marcos Paulo da Silva e Prof. ${ }^{a}$ Dr $^{\text {a }}$. Gracy Mara França que, além de supervisionarem a pesquisa, proporcionaram um valioso contato com pesquisadores e jornalistas sul-mato-grossenses e foram importantes estímulos à pesquisa vinculada à docência.

Ao Prof. Dr. Manuel Pinto, pelo aprendizado e supervisão durante o breve período de estudos na Universidade do Minho, em Portugal, entre setembro e dezembro de 2017.

Aos profissionais que me ajudaram no início de minha formação como radialista e por meio deles dedico minha chegada a esta etapa como pesquisador: José Maria Saes Rosa, Carlos Eduardo Gaiad, Rubens Franco de Camargo, Alícia Nascimento Aguiar, Maria Lúcia Potascheff, Edmilson Messias (Bill), Fábio Gimenez Paschoal e João Theodoro de Oliveira.

Principalmente aos membros do Departamento de Comunicação do Comitê Olímpico do Brasil, por possibilitarem uma aproximação técnica e teórico-metodológica com a produção do website estudado nesta tese: Cláudio Motta, Christian Dawes e Adriano Winckler. 


\section{Agradecimentos}

A meus familiares: Carlos Augusto Tavares e Maria Suely Messias Tavares, pais que acreditaram em mim e apoiaram meus sonhos.

À minha avó materna Mathilde Bruno Messias e aos meus tios que me apoiaram em vários momentos: João Messias Neto, Rosária Inês Messias Machado e Wilma Regina Tavares Galati.

Ao Prof. Dr. Enio Moraes Júnior, pela revisão desta tese e pelo importante legado deixado por sua pesquisa de doutorado, defendida no PPGCOM-USP em 2011, que inspirou a metodologia de análise de entrevistas.

Aos incríveis amigos que conheci durante os estágios discentes realizados em Campo Grande e em Braga: Maria Donizeti de Sena, Maria Irene Silva Rocha e Manuel Vilela Silva.

Aos docentes da Escola de Comunicações e Artes da Universidade de São Paulo: Prof. Dr. Dennis de Oliveira, pelos conselhos pontuais sobre pesquisa científica; Prof. $^{\text {a }}$ Dr $^{\mathrm{a}}$. Cremilda Medina e Prof. ${ }^{a}$ Dr $^{\mathrm{a}}$. Clarissa Gagliardi, pelas informações valiosas nas disciplinas ministradas.

Aos membros da banca de qualificação deste trabalho que, por meio de valiosos e pontuais apontamentos, possibilitaram que o estudo viesse a ser desenvolvido com mais atenção e afinco.

Em memória de Romilda Dall’Acqua, avó paterna que completaria 100 anos em 2019. 
Você não tem nada no esporte que não tenha a emoção do conflito. Então, o importante é levar para o esporte o jornalismo, com todas as suas exigências éticas, técnicas e culturais.

Manuel Carlos Chaparro 


\section{Resumo}

TAVARES JUNIOR, Carlos Augusto. Rio 2016: o Jornalismo Esportivo e o Comitê Olímpico do Brasil. 2019. 154f. Tese (Doutorado) - Escola de Comunicações e Artes, Universidade de São Paulo, São Paulo, 2019.

Esta tese analisa o website do Comitê Olímpico do Brasil (COB), tendo como base a discussão em torno do jornalismo esportivo, desde a perspectiva teórico-conceitual à produção e a usabilidade diante das mediações tecnológicas. A página do $\mathrm{COB}$ apresenta um potencial diferenciado para a produção de notícias, ao abrigar características com pouca recorrência nos noticiários brasileiros, focados nos esportes de alto rendimento, na competição e na popularidade das modalidades e de atletas. Surge um desafio nessa cobertura: ampliar a visibilidade das modalidades na mídia e a necessidade de priorizar os valores esportivos como a excelência, o respeito e a amizade. Esse potencial vai além da cobertura das principais competições, como os campeonatos mundiais e os Jogos, ocorridos no Rio de Janeiro, em 2016. Assim, esta pesquisa tem como principal objetivo responder à seguinte pergunta: o site do COB, ao proporcionar que usuários-interatores acessem as informações dos principais acontecimentos das modalidades olímpicas, teria sido utilizado como fonte para a criação de pautas a serem desenvolvidas pelos jornalistas especializados em esportes? Com a finalidade de abordar a discussão do modo de uso / funcionalidade do conteúdo eletrônico jornalístico do Comitê Olímpico do Brasil, este trabalho se debruça sobre a coleta e a análise de entrevistas com pesquisadores, jornalistas e profissionais da mídia.

Palavras-chave: Comitê Olímpico do Brasil. Jogos Olímpicos Rio 2016. Jornalismo esportivo. Olimpismo. 


\begin{abstract}
TAVARES JUNIOR, Carlos Augusto. Rio 2016: Sports Journalism and the Brazilian Olympic Committee. 154p. Doctoral Thesis - School of Communications and Arts, University of São Paulo, São Paulo, 2019.

This thesis has the purpose to analyse the website of the Brazilian Olympic Committee (COB), based at the discussion around sports journalism, from the theoretical concept from varying mediations to production and usability. The $\mathrm{COB}$ web page brings a different potential for news production, hosting features with little recurrence in Brazilian newscasts, focused on highperformance sports, competition and the popularity of modalities and athletes. Thus, a challenge arises in this coverage, which is to increase the visibility of Olympic sports in the media and the need to prioritize sports and Olympic values such as excellence, respect and friendship. This potential goes beyond the main competitions coverage, such as the world championships and the Olympic Games, which took place at Rio de Janeiro in 2016. Thus, this research has as main objective to answer the following question: The COB website, by providing that userinteractors access information on the main events of the Olympic modalities would have been used as a source on the development of guidelines to be developed by journalists specialized in sports? With the purpose of discussing the use / functionality of the journalistic web contents from the Brazilian Olympic Committee, this thesis also focuses on the collection and analysis of interviews with researchers, journalists and media professionals.
\end{abstract}

Keywords: Brazilian Olympic Committee. Rio 2016 Olympic Games. Sports Newsmaking. Olimpism. 


\section{LISTA DE SIGLAS}

ABT: Academia Brasileira de Treinadores

CCPJ: Comissão da Carteira Profissional de Jornalista

COB: Comitê Olímpico do Brasil

COM: Comitê Organizador dos Jogos Olímpicos e Paralímpicos Rio 2016

COP: Comité Olímpico de Portugal

COI: Comitê Olímpico Internacional (abreviatura comum na mídia brasileira)

CPU: Unidade central de processamento (Central Processing Unit)

DVD: Digital Versatile Disk

FIFA: Fédération Internationale de Football Association

IOC: Comitê Olímpico Internacional (abreviatura internacional)

Libras: Linguagem Brasileira de Sinais

OBS: Olympic Broadcast System (Sistema Olímpico de Radiodifusão)

RHB: Right Host Broadcasting (Direito de transmissão de emissora licenciada)

RTP: Rádio e Televisão de Portugal

RUM: Rádio Universitária do Minho

UERJ: Universidade do Estado do Rio de Janeiro

UFMS: Universidade Federal do Mato Grosso do Sul

UFJF: Universidade Federal de Juiz de Fora

UFJR: Universidade Federal do Rio de Janeiro

USC: Universidade Santiago de Compostela

USP: Universidade de São Paulo

UMINHO: Universidade do Minho

UOL: Universo Online

WEB: World Wide Web 


\section{LISTA DE FIGURAS}

Figura 1 - Site do COB: visão geral (zoom expandido) da primeira página 15

Figura 2 - Página do COB a partir de navegador desatualizado 58

Figura 3 - "Sobre o COB" 59

Figura 4 - Vídeo institucional "Cidade Olímpica" 62

Figura 5 - "Cidade Olímpica": playlists

Figura 6 - "Cidade Olímpica": vídeos marcados com Gostei 63

Figura 7 - "COB": cabeçalho da página 63

Figura 8 - Anúncio do conteúdo em Libras. 64

Figura 9 - Átrio de conteúdos 67

Figura 10 - Mural com atletas de destaque olímpico no COB 67

Figura 11 - Acervo bibliotecário voltado aos esportes olímpicos 68

Figura 12 - Corredor de acesso 68

Figura 13 - Salas de reuniões 68

Figura 14 - Jornalistas do Comitê Olímpico do Brasil. 69

Figura 15 - Página 'não oficial' do COB no Facebook 


\section{LISTA DE QUADROS}

Quadro 1 - Conceitos de jornalismo esportivo

Quadro 2 - A pauta olímpica 46

Quadro 3 - Conteúdo multimídia do site do Comitê Olímpico do Brasil 64

Quadro 4 - Interfaces da pauta esportiva com outras áreas 66

Quadro 5 - Paixão e emoção: síntese 121

Quadro 6 - Premissa e hipótese: síntese 124

Quadro 7 - Mídia convencional x mídia alternativa e especializada: síntese 144 


\section{SUMÁRIO}

1. INTRODUÇÃ̃O

2. JORNALISMO ESPORTIVO E A PAUTA OLÍMPICA NO BRASIL 23

2.1. O que é jornalismo esportivo?.

2.1.1. Em busca de um conceito de jornalismo esportivo. 34

2.2. O desenvolvimento da pauta olímpica no Brasil 36

3. MÍDIAS DIGITAIS E O SITE DO COMITÊ OLÍMPICO DO BRASIL . 48

3.1. Comunicação digital: dinâmicas e espaços............................................................ 54

3.2. Esportes e Jogos Olímpicos: site do COB .............................................................. 57

3.3. O site do Comitê Olímpico do Brasil in loco: visita técnica ....................................67

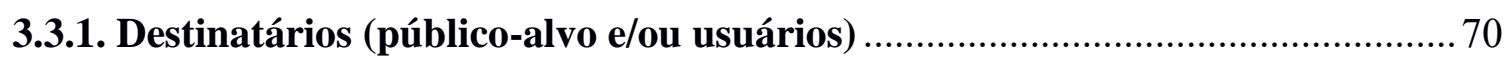

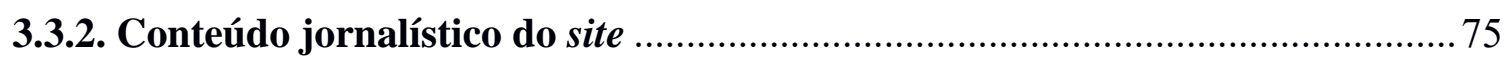

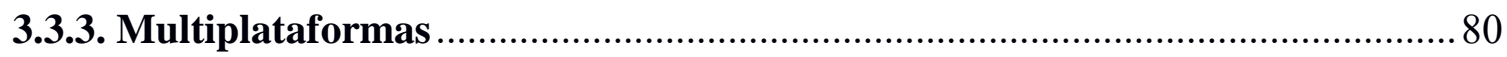

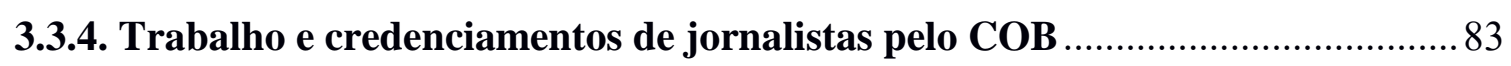

4. A COBERTURA OLÍMPICA: CONSULTA AOS JORNALISTAS .......................... 92

4.1. Fontes de informação jornalística: dos contatos ao ciberespaço ........................... 92

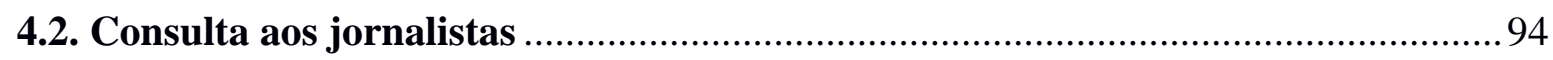

4.2.1. A cobertura jornalística dos Jogos Olímpicos no Rio de Janeiro em 2016 ..... 99

4.2.2. A utilização do site do COB como fonte de informação ................................ 109

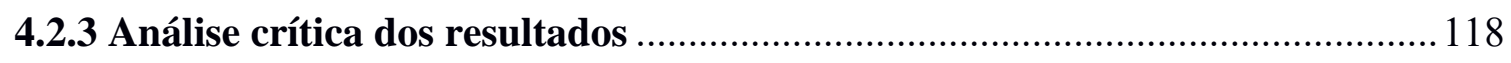

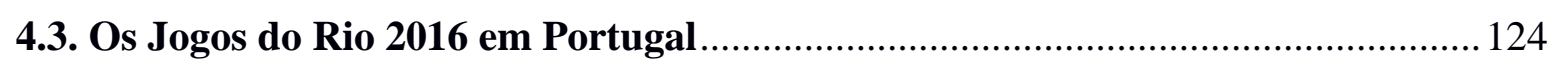

4.3.1. A cobertura dos Jogos Olímpicos no Rio de Janeiro em 2016 por jornalistas

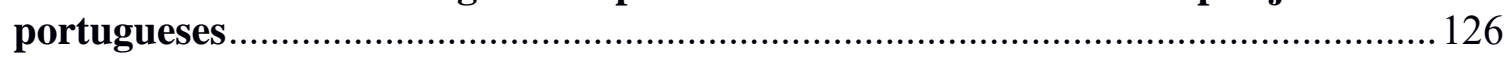

4.3.2. Utilização do site do COB como fonte no jornalismo português .................... 135

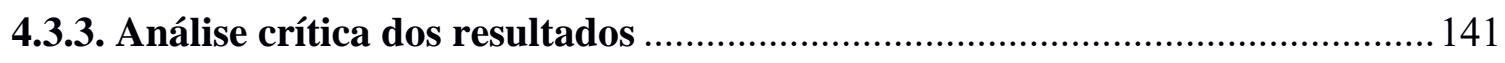

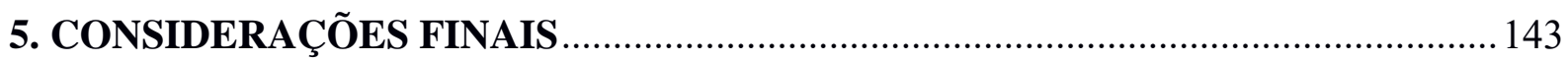

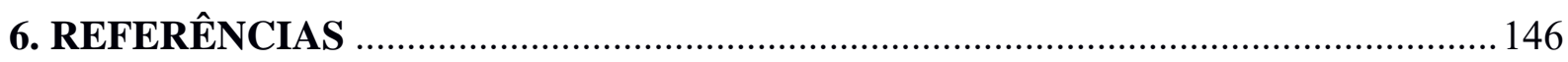




\section{INTRODUÇÃO}

O jornalismo esportivo apresenta diversas vertentes e desdobramentos. Por isso, são estabelecidas diferentes abordagens para o seu estudo, levando em conta aspectos epistemológicos, filosóficos e linguísticos. Assim, torna-se necessário referenciar que, nesta área do jornalismo, as pautas (LAGE, 2014) e, posteriormente, as explicações para os assuntos mais complexos convergem para o viés esportivo por meio de construções simples e acessíveis.

$\mathrm{Na}$ editoria dos esportes, o relato jornalístico e o feedback do público também resultam do entendimento da notícia. Diante dessa premissa e apenas como ponto de referência da principal discussão desta tese, parece essencial ampliar o conceito de editoria de esporte do jornalista Luiz Amaral (1982, p.89) ao sublinhar que a:

(...) editoria de esporte é o local da redação leve, suave, fácil, viva, em que cabem o humor, o pitoresco, o fato engraçado, as expressões consagradas pelo espírito popular e os modismos empregados em doses racionais.

A realização de eventos e competições internacionais no Brasil, como a Copa do Mundo da Fédération Internationale de Football Association (FIFA), em 2014, e os Jogos Olímpicos de Verão ${ }^{1}$, no Rio de Janeiro, em 2016, proporcionou oportunidade para a aproximação entre as pautas esportiva e olímpica. Assim, ocorreram discussão de temas que não teriam a mesma dimensão se o local do evento não fosse o Brasil, como os gastos com jogos e a construção de infraestrutura, cujos temas normalmente estariam associados a outras editorias, especialmente a internacional. Desse modo, as editorias que passaram a tratar da cobertura esportiva também forneceram indícios para o pressuposto de uma comunicação que envolvesse assuntos mais complexos do cotidiano brasileiro, como se qualquer problema se resolvesse por meio da abordagem esportiva.

Nessa empreitada, as notícias acerca dos Jogos Olímpicos do Rio 2016 ofereceram a possibilidade de ampliar e envolvimento do público com as diversas modalidades ${ }^{2}$ pouco

\footnotetext{
${ }^{1}$ O Brasil foi o primeiro país da América do Sul a sediar uma edição dos Jogos Olímpicos de Verão, realizados de 03 a 29 de agosto de 2016, no Rio de Janeiro. O evento também se tornou conhecido e referido na mídia por meio da marca Rio 2016.

${ }^{2}$ As modalidades disputadas no Rio 2016 foram: atletismo, badminton, basquete, boxe, canoagem slalom, canoagem, ciclismo BMX, ciclismo mountain bike, ciclismo de estrada, ciclismo de pista, esgrima, futebol, ginástica artística, ginástica rítmica, ginástica de trampolim, golfe, handebol, hipismo adestramento, hipismo concurso, hipismo saltos, hóquei sobre grama, judô, levantamento de peso, luta livre, luta greco-romana, maratona aquática, nado sincronizado, natação, pentatlo moderno, polo aquático, remo, rugby 7s, saltos ornamentais, tae-kwon-do, tênis de mesa, tênis, tiro com arco, tiro esportivo, triatlo, vela e vôlei de praia.
} 
conhecidas. Por exemplo, vela, judô, tae-kwon-do e atletismo terminaram ganhando espaço diante de esportes que, tradicionalmente, no Brasil, têm mais visibilidade, como basquete, vôlei, natação e, obviamente, futebol.

No contexto dos Jogos Olímpicos que aconteceram no Brasil, destacam-se também fatores que integraram a cobertura jornalística como as "janelas'³ e a concepção de olimpismo. O professor Manoel José Gomes Tubino (2007, p.05) explica como se dá essa construção:

O olimpismo, na percepção do Comitê Olímpico Internacional (COI), de acordo com a carta olímpica, é entendido como a base filosófica que envolve o movimento olímpico e exalta as qualidades do corpo, a vontade e o espírito, associando-se ao esporte, à educação e à cultura. O olimpismo é considerado a própria filosofia do esporte, contribuindo para um estilo de vida das pessoas, pela alegria do esforço físico, valor educativo do bom exemplo e respeito pelos princípios éticos universais.

Há um consenso mundial que o olimpismo é a manifestação suprema do esporte, pois representa a ética esportiva e constitui-se em sua maior expressão. (Itálico nosso)

No projeto olímpico, incluem-se valores esportivos - como a moral e a ética das modalidades, exemplificada pelo fair play - e a história dos atletas que passam a protagonizar sagas e lutas de superação. A eventual conquista de uma medalha, segundo Tubino (2007, p.11), representa "uma condecoração para pessoas físicas que elevaram o ideal olímpico".

Nesse contexto, emergiu um caldeirão efervescente com assuntos de planejamento de infraestrutura que envolveu especialidades de distintas áreas do jornalismo, como as editorias de política, economia e comportamento (lazer, turismo e moda). De certo modo, em alusão às explicações de Tubino (2007, p.12), considera-se tais interfaces inerentes ao Programa Cultural Olímpico, relacionado com as áreas de "Turismo, Educação, Memória, História, Arquitetura, Literatura, Música".

Esta pesquisa tem como principal objetivo analisar e discutir o website ${ }^{4}$ do Comitê Olímpico do Brasil (COB), que abriga diversos conteúdos jornalísticos, como os que aparecerem na tela principal: notícias (reportagens), vídeos e fotos. No site, além da separação dos tópicos, há uma diferenciação específica para o teor da notícia. Assim, a home

\footnotetext{
${ }^{3}$ Períodos de vazios informativos referentes à preparação e lacunas entre competições, férias ou outros.

${ }^{4} \mathrm{O}$ termo utilizado em inglês para página da rede originalmente possui a grafia website. Entretanto, a menção com mais recorrência no Brasil e também em Portugal (por meio da viagem de estudos realizada entre outubro a dezembro de 2017) utiliza predominantemente a escrita em inglês site (pronunciada "saite"). A utilização da variação sítio da web teve a finalidade de evitar a redundância em parágrafos.
} 
exibe uma entrada para três minissítios intrincados com cores diferentes nos rótulos, alusivos à bandeira brasileira: $C O B$, em azul, para o conteúdo institucional; Time Brasil, em verde, voltado para os esportes olímpicos; e Jogos Escolares, em amarelo, específico para a revelação de novos atletas e categorias de base (imagem a seguir):

Figura 1 - Site do COB: visão geral (zoom expandido) da primeira página
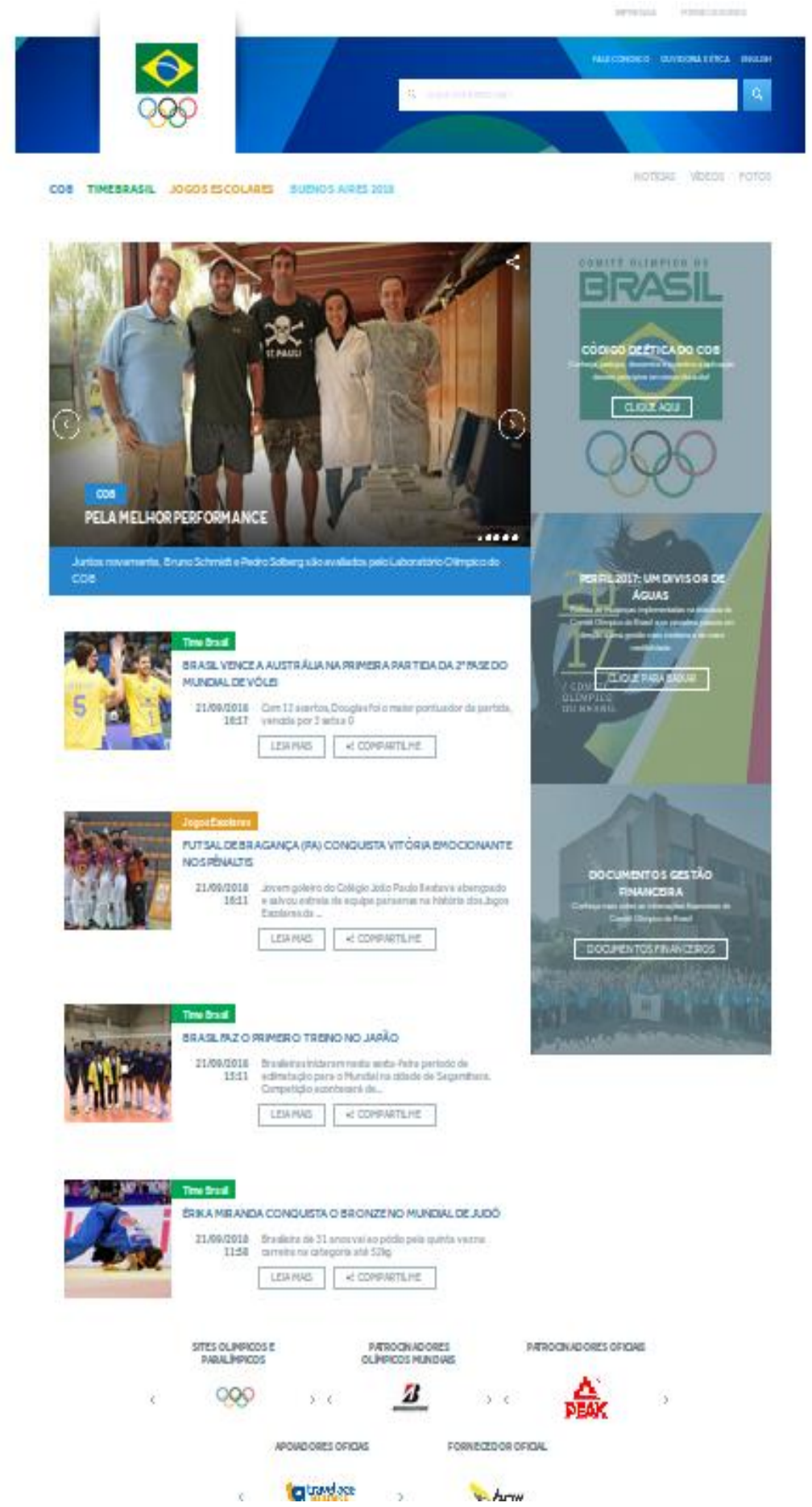

Fonte: http://www.cob.org.br. Acesso em: 22 nov. 2016 
A disponibilização da produção do noticiário esportivo e olímpico pode ser vista na grande mídia conforme a recorrência de pautas e, sobretudo, das categorias com visibilidade na cobertura. Entretanto, algo impacta esse trabalho: a abordagem primordial do futebol, em detrimento de outras modalidades esportivas compreendidas na edição de 2016 dos Jogos Olímpicos. A partir dessa constatação, o papel de mediação do COB se estabelece desde a elaboração da pauta, passando pelo desenvolvimento de reportagens e, possivelmente, como fonte de abastecimento da mídia na cobertura de esportes com pouca visibilidade e familiaridade junto aos espectadores.

Professor e pesquisador da Universidade Federal da Bahia (UFBA), Elias Machado (2003) afirma que o jornalismo recorre ao ciberespaço como espaço de reunião das fontes pelos jornalistas profissionais da mídia convergente. Ao mesmo tempo que o meio digital provê ferramentas interativas entre os usuários, a linguagem das interfaces confere recursos complementares para reunir informações jornalísticas, com a possibilidade de que sites forneçam materiais apropriados para a difusão de notícias a partir de instituições organizadoras - nesse caso, do Comitê Olímpico do Brasil. Por isso, buscou-se analisar o jornalismo esportivo tendo como objeto de análise o $\mathrm{COB}$, nos seguintes âmbitos:

- Produção de conteúdo noticioso em diferentes possibilidades de internet (gravações caseiras, arquivos e material disponibilizado em portais de compartilhamento de mídia, como YouTube e Soundcloud, entre outros), fotografias, vídeo e áudio;

- Articulação das pautas desde quando elas se transformam em notícia até chegarem aos meios, incluindo as plataformas cibernéticas como complementação da notícia: canais de interatividade, ilustrações explicativas de utilização das interfaces midiáticas (em blogs e redes sociais como Twitter e Facebook) e sítios de comunidades dedicadas às modalidades com menos visibilidade na grande mídia (tiro com arco, salto ornamental e handebol, entre outros).

Em um primeiro momento, esse tipo de contexto sugere proximidade com a ideia de mediação (MARTÍN-BARBERO, 2010), interligando sujeitos-conectores por conta da existência de espaços abertos a produções alternativas e populares e de perfis diferenciados da comunicação. Nesse caso, destaca-se o uso de material de divulgação de eventos esportivos, apesar de ser produzido a partir de notícias que possuem outro perfil de 
comunicação, não direcionado ao público do jornalismo, nem constituindo publicidade de torneios internacionais.

Na cobertura esportiva, alguns impactos não devem ser subestimados, como a produção de vídeos virais e de conteúdo humorístico, a exemplo do escárnio a equipes e seleções esportivas rivais. Essas práticas coexistem com a geração de programas de curta duração com teor opinativo em espaços de compartilhamento de material, como o YouTube, quando um usuário se lança como atração e passa a construir sua própria opinião.

Isso chama a atenção quando assuntos eliminados da pauta esportiva convencional passam a ser abordados diretamente, ao exemplificarem problemas de complexidade, como discordar de uma nota "8.3" atribuída por um juiz para um salto ornamental sem aparente desequilíbrio do atleta. Deste modo, o nível dos comentários das transmissões de esportes olímpicos tende a externar uma opinião de teor técnico, ainda que a prática de repetir a argumentação como estratégia de persuadir e contestar possíveis dúvidas contraste com o esclarecimento sobre critérios e regras.

Esta tese desenvolve uma abordagem do jornalismo esportivo no contexto da comunicação cibernética, quando a ocorrência de compartilhamento e produção de material noticioso também parte de usuários que interagem e geram conteúdo a ser disponibilizado no ciberespaço. Dessa maneira, a interatividade e a expressão de opiniões também podem colaborar e fomentar a produção de conteúdo.

Para investigar os múltiplos processos de interação no rádio, a teoria cibernética especifica espaços de convivência (RÜDIGER, 2007, p.46) a partir de plataformas digitais. Entretanto, apenas com a efetiva adoção do recurso multimídia nos computadores, na segunda metade da década de 1990 e, posteriormente, a contratação de serviços de comunicação, as redes informáticas passaram a possibilitar a base da virtualização (LÉVY, 1999) da interação social a partir do que se pratica hoje. Esse processo também ocorre em ambientes diferenciados a partir de metaversos ${ }^{5}$ característicos, cuja finalidade conduzida pelos usuários faz parte das obras coletivas, a partir do conceito de Jeff Howe (2009).

Além da comunicação interindividual, a internet propiciou a prática da experiência da criação de produtos pelas multidões, como o software livre, aperfeiçoado por comunidades que interagem entre si.

Para o jornalismo, de forma geral, o desenvolvimento das tecnologias de

\footnotetext{
${ }^{5}$ Presente no contexto dos meios digitais, o termo metaverso diz respeito à possibilidade de recriar e replicar a realidade.
} 
comunicação e dos espaços cibernéticos implicou muitas mudanças. Uma delas, extremamente pertinente a esta tese, diz respeito à perda dos privilégios da mídia tradicional ou grande imprensa. Com isso, nas últimas décadas, outras formas de comunicar e informar passaram a se desenvolver e a se consolidar. As nomenclaturas são várias - mídia alternativa, independente ou especializada - mas todas elas se referem a formas de comunicação que já existiam, mas ganharam novo fôlego com o potencial trazido pelas tecnologias.

Os blogueiros ${ }^{6}$ que conquistam visibilidade em redes sociais não se confundem com os tradicionais showman do rádio ou televisão. Uma vez que a profusão de canais segmentados contempla campos distintos de informação, a existência de jornalistas bloggers envolvidos na produção de conteúdo alternativo contribuiu para que essa atuação ganhasse espaço e crescesse em canais digitais, concorrendo com celebridades e grandes canais da mídia.

Entretanto, o filósofo e músico alemão Gerd Leonhard (2010, p.02) esclarece que "na internet nada é de graça", mas custeado de alguma maneira por empresas ou anunciantes que passam a disponibilizar plataformas interativas de produção e criação coletiva, como por exemplo a empresa Google com os serviços G-sites e G-apps.

Nessa dinâmica, o compartilhamento em rede estabelece formas de reunir sujeitos quando as produções não dependem necessariamente dos meios. Porém, constata-se uma consequente inversão da mediação quando canais eletrônicos (rádio e televisão) no ciberespaço passam a oferecer alternativas de entretenimento no ambiente da convergência (JENKINS, 2009). A exemplo disso, o canal por assinatura SporTV traz para os assinantes um videogame com ênfase na gestão de um clube de futebol, o Cartola FC?

Autores como Henry Jenkins (2009), Jesús Martín-Barbero (2010) e Everett Rogers (2003), além de Wilton Garcia (2011), Elias Machado (2003) e Pollyana Ferrari (2010b), forneceram subsídios para discutir as mudanças que a sociedade e a comunicação têm sofrido com a presença de dispositivos eletrônicos na contemporaneidade.

Artur da Távola (1985) e Roberto Damatta (1985; 1994) ajudaram a entender a convivência na sociedade da informação, em que o esporte faz parte da cobertura jornalística diária. O jornalismo, por sua vez, foi retratado nesta tese com base em José Carlos Marques (2007), Manuel Pinto (2000), Nilson Lage (2014), Mário Erbolato (1981) e Luiz Amaral (1982).

\footnotetext{
${ }^{6}$ Brasileirismo adaptado da palavra inglesa bloggers (usuários de blogs).

${ }^{7}$ Site SPORTV (canal pago). Disponível em: 〈http://sportv.globo.com/site/cartola-fc〉. Acesso em: 22 mai. 2015.
} 
Esta pesquisa aborda a produção jornalística do esporte na mídia com ênfase na cobertura do Comitê Olímpico do Brasil durante os Jogos Olímpicos de Verão, que ocorreram no Rio de Janeiro, em 2016. Por meio de uma análise prévia do site do COB, demonstra-se a existência de pressupostos da convergência midiática ao abranger a produção transversal da cobertura jornalística esportiva com o auxílio de fontes jornalísticas.

As páginas de internet propiciam que, além da apresentação textual, outro tipo de material multimídia coexista nesse universo de modo peculiar, no mesmo local ou endereço web. Considerando-se o tratamento da produção de notícias, as fontes (LAGE, 2014, p.49) contam com acréscimos a partir da vinculação de imagem, áudio e vídeo que tratam e complementam o assunto abordado com outras formas de testemunhar os fatos e as notícias.

$\mathrm{Na}$ cobertura de eventos esportivos, são comuns dúvidas e especulações acerca do que ocorre. Por exemplo, as suspeitas sobre uso de indumentária química no organismo de atletas, como o doping, que provoca desequilíbrio em competições. Desse modo, um corredor franzino tem mais agilidade em torneios de velocidade ao mesmo tempo que, em uma maratona, outro fator contabiliza a vantagem além da velocidade, como a capacidade de percorrer distâncias longas em períodos curtos. De forma comparativa, a resistência de quem possui e adquiriu massa muscular favorece corredores vigorosos, que ficam exaustos em relação àqueles com mais rapidez de arranque.

Do ponto de vista da metodologia, esta tese teve como base a pesquisa qualitativa (MINAYO, 1994) para discutir seu objeto: o site do COB. Para isso, foram realizadas entrevistas a partir dos parâmetros observados pelo professor da Universidade de La Sabana, na Colômbia, César Augusto Bernal Torres (2010, p.63):

$\mathrm{Na}$ coletividade, definem-se as ações a serem realizadas e a maneira de fazê-lo; do mesmo modo, as técnicas e ferramentas para obter informações na análise e solução do problema são definidas. Para isso, são utilizadas técnicas como reuniões, registros de diários de campo que são desenvolvidos durante o processo de estudo, sociodramas, entrevistas, observação participante estruturada, experiências autobiográficas, histórias de vida etc. (Tradução nossa) ${ }^{8}$

\footnotetext{
${ }^{8}$ No original, em espanhol: "Desde la colectividad se definen las acciones por llevar a cabo y la manera de hacerlo; asimismo, se definen las técnicas y herramientas para la obtención de información en el análisis y la solución del problema. Para ello, se utilizan técnicas como reuniones, registros de diarios de campo que van elaborándose durante el proceso del estudio, sociodramas, entrevistas, observación participante estructurada, experiencias autobiográficas, historias de vida, etcétera". (Itálicos nossos)
} 
As entrevistas foram realizadas com pessoas selecionadas ${ }^{9}$ de acordo com seu perfil profissional, acadêmico ou por conta do trabalho que realizaram na cobertura das Olimpíadas de 2016 e acabaram por contribuir decisivamente na elaboração das análises desenvolvidas neste trabalho.

O capítulo a seguir, Jornalismo esportivo: a pauta olímpica no Brasil, discute duas questões: o que é jornalismo esportivo e como está sendo desenvolvida a pauta olímpica no Brasil. As perguntas foram respondidas pelos seguintes entrevistados: Prof. Dr. Ronaldo George Helal, Prof. Dr. Manuel Carlos Chaparro, Prof. Dr. José Carlos Marques, Prof. Dr. Márcio de Oliveira Guerra, Prof. Dr. Ary Rocco Júnior, Prof. Dr. Anderson Gurgel, Prof. Dr. Felipe Tavares Paes Lopes, Prof. João Jair Sartorelo e pelos jornalistas Arthur Mário Medeiros Ramalho e Eva Regina de Freitas. Em caráter comparativo, as mesmas perguntas, com foco na mídia espanhola, foram direcionadas ao Prof. Dr. Carlos Toural Bran.

Mais adiante, o capítulo Mídias digitais e o site do Comitê Olímpico do Brasil busca levantar conceitos sobre o ciberespaço, tema que tangencia o locus da página online do COB, bem como discute a funcionalidade que transcende o meio eletrônico e que se relaciona diretamente com as especificidades regionais e locais, como o contexto do Brasil e as questões que se desenrolam a partir da cidade-sede dos Jogos Olímpicos de 2016, o Rio de Janeiro. Essa etapa também contempla a visitação técnica às dependências do Comitê Olímpico do Brasil, onde se dá a produção do site analisado, com entrevista com os jornalistas que atuam na instituição: Cláudio Motta, Christian Dawes e Adriano Winckler.

O último e principal capítulo, intitulado A cobertura olímpica no Brasil: consulta aos jornalistas, procurou saber de profissionais que registraram o evento como foi a cobertura dos Jogos Olímpicos do Rio de Janeiro em 2016 e se eles utilizaram algum material da página do $\mathrm{COB}$ durante seu trabalho. Em caso positivo, perguntou-se se lembrariam quais foram os conteúdos usados. Em caso negativo, qual fonte da web teriam consultado.

No âmbito do jornalismo brasileiro, as perguntas foram respondidas pelos profissionais: José Ricardo Campos Leite (portal UOL e canal FOX Sports), Fábio França (Rede Bandnews FM), Fernando Saraiva (Canal SporTV), Victor Sá Ramalho Antonio (Portal do Rugby), Geraldo Armando Cardoso Neto (EPTV Ribeirão Preto), Rafael Bullara (jornal Lance!), Vitor Prates (Blog do Vitor Prates), Nathália Ely Siqueira (site Travinha),

\footnotetext{
${ }^{9}$ Esta questão encontra-se melhor explicada, caso a caso, na apresentação de cada um dos entrevistados, ao longo deste trabalho.
} 
Marcus Von Groll (site Travinha) e Sérgio Settani Giglio (portal Ludopédio).

Em uma abordagem nos parâmetros dos estudos comparados, procurou-se estabelecer uma associação entre as questões deste último capítulo no contexto da cobertura olímpica realizada por jornalistas de Portugal. Assim, foram entrevistados os jornalistas portugueses Daniel Vieira da Silva (Rádio Universitária do Minho), Carlos Miguel Machado (jornal Correio do Minho), Carlos Flórido (jornal e site O Jogo), Fernando Eurico (rádio Antena 1 e canal RTP) e Pedro Jorge da Cunha (site Maisfutebol).

No processo de entrevistas que permeou o desenvolvimento dos capítulos deste trabalho, tomou-se como diretriz a abordagem direta dos temas a partir do enfoque subjetivo de cada entrevistado, conforme o pensamento da professora e pesquisadora da USP, Cremilda Medina (1986, p.05-06), considerando-se um possível diálogo entre entrevistador e entrevistado:

\begin{abstract}
Um leitor, ouvinte ou telespectador sente quando determinada entrevista passa a emoção, autenticidade, no discurso enunciado tanto pelo entrevistado quanto no encaminhamento das perguntas pelo entrevistador. Ocorre com limpidez, o fenômeno da identificação, ou seja, os três envolvidos (fonte de informação - repórter - receptor) se interligam numa única vivência. A experiência de vida, o conceito, a dúvida, ou o juízo de valor do entrevistado transformam-se numa pequena grande história que decola do indivíduo que narra para se consubstanciar em muitas interpretações. (Itálicos da autora)
\end{abstract}

As entrevistas que compõem o último capítulo consideraram a experiência prática dos jornalistas em relação às Olimpíadas do Rio de Janeiro e permitiram responder ao problema de pesquisa sobre a utilização do site do $\mathrm{COB}$ como fonte para a produção de notícias sobre o evento. A complexidade das respostas fez surgir a pergunta complementar sobre as particularidades da cobertura nos Jogos Olímpicos a partir do local e demais fontes da web que teriam auxiliado no trabalho jornalístico. Como hipótese principal, esta tese considerou que a web, de fato, forneceu ferramentas para a produção de notícias, entre estes espaços, a página online do COB.

Com forte investimento em entrevistas, o presente trabalho concentrou grande parte dos seus esforços na seleção e análise dos principais tópicos observados na fala dos entrevistados. Desta forma, tornou-se possível responder às questões, bem como comprovar a hipótese suscitada.

Ressalte-se ainda que os diálogos com os pesquisadores, professores e jornalistas foram importantes tanto na ponderação relativa a conceitos - jornalismo esportivo e pauta 
olímpica - como no que diz respeito ao próprio uso do site do COB como fonte de informação jornalística na elaboração de matérias durante as Olimpíadas.

As entrevistas foram realizadas in loco com captação em áudio registrada com o auxílio do aplicativo de gravação sonora TwistedWave. O processo de transcrição ocorreu de forma manual, com ajuda de softwares de áudio como Audacity e SoundForge. 


\section{JORNALISMO ESPORTIVO E A PAUTA OLÍMPICA NO BRASIL}

A denominação pauta aplica-se a duas coisas distintas:

a) $\mathrm{O}$ planejamento de uma edição ou parte da edição (nas redações estruturadas por editorias - de cidade, política, polícia, economia etc.), com a listagem dos fatos a serem cobertos no noticiário e dos assuntos a serem abordados em reportagens, além de eventuais indicações logísticas e técnicas: ângulo de interesse, dimensão pretendida da matéria, recursos disponíveis para o trabalho, sugestões de fontes etc.

b) Cada um dos itens desse planejamento, quando atribuído a um repórter. Ele dirá: "a minha pauta", quer a tenha recebido como tarefa, quer a tenha proposto (o que é comum, particularmente como freelancers).

(LAGE, 2014, p.34)

Este capítulo foi elaborado com base na realização e análise de entrevistas feitas com profissionais, pesquisadores e professores da área do jornalismo esportivo no Brasil, tendo como pretexto a edição dos Jogos Olímpicos de Verão de 2016, na cidade do Rio de Janeiro. Diante disso, torna-se importante apresentar uma discussão em torno da pauta esportiva e olímpica, considerando algumas características da contemporaneidade, como o impacto da tecnologia e da multimídia convergente e as especificidades da cobertura jornalística especializada em esportes. Neste contexto, o futebol predomina diante das demais modalidades, fato constatado por Mário Erbolato (1981, p.14), pesquisador que também foi professor de jornalismo da Pontifícia Universidade Católica de Campinas (PUC-Campinas):

Pode-se dizer que o futebol, fortalecido depois que o Brasil se tornou tricampeão mundial, é o esporte que mais entusiasma a maioria dos brasileiros. Mesmo os que normalmente pouco se interessam por determinado quadro começam a incentivá-lo e a desejar que obtenha a vitória se um clube participar com destaque de um campeonato.

A análise do site do Comitê Olímpico do Brasil (COB) incide, primeiramente, na adequação do perfil desse sítio como fonte de informação para jornalistas. Dessa maneira, se propõe um direcionamento focado na temática abordada com base na busca conceitual pelos termos 'jornalismo esportivo' e 'pauta olímpica'.

A pesquisa contemplou entrevistas com especialistas - professores universitários de comunicação social e de educação física, além de jornalistas - para a discussão de questões relacionadas à cobertura esportiva no Brasil:

- O que é jornalismo esportivo? 
- Como está sendo desenvolvida a pauta olímpica no Brasil?

A partir deste ponto, a pesquisa contemplou as respostas tangenciadas pela bibliografia e pelo material multimídia, no contexto da entrevista estruturada que, de acordo com Bernal Torres (2010, p. 256-257):

Entrevista estruturada: [...] essa entrevista também é chamada de entrevista diretiva; é realizada a partir de um esquema ou formato de questões previamente elaboradas, proposto na mesma ordem e nos mesmos termos para todas as pessoas entrevistadas. [...] As entrevistas requerem entrevistadores altamente treinados que, ao mesmo tempo, conheçam amplamente o objeto de estudo. (Tradução nossa) ${ }^{10}$

Para investigar o site do $\mathrm{COB}$, foram consideradas desde a adequação do perfil do endereço cibernético do Comitê como um meio de produção de conteúdo jornalístico - como será observado no capítulo destinado à visita técnica - até uma posterior análise dessa mídia como fonte de informação para jornalistas - como estará descrito no último capítulo.

Com o objetivo de valorização do conteúdo comunicacional local e regional, além de pesquisadores renomados, dois jornalistas sul-mato-grossenses foram incluídos na lista de entrevistados, ressaltando a prática da editoria de esporte em uma área distante do eixo São Paulo e Rio de Janeiro.

\subsection{O que é jornalismo esportivo?}

No Brasil a atuação da especialidade do jornalismo destinada aos esportes pode não demonstrar, a priori, reflexos decorrentes da pauta com as interfaces esportivas na produção midiática e de como o contexto esportivo, sobretudo, como os termos "ginga, drible e regras", acabaram assimilados no cotidiano nacional. Nesse sentido, o sociólogo italiano e pesquisador de temas brasileiros Domenico De Masi (2015, p.44) destaca:

O conceito de "brasilidade" refere-se ao encontro e às relações interpessoais. As relações abrangem indivíduos. O individualismo assume uma conotação negativa. Viver significa "ter relações sociais". "Saudade"

\footnotetext{
${ }^{10}$ No original, em espanhol: "En investigación hay diferentes tipos de entrevista; sin embargo, es usual clasificar las entrevistasen: estructurada, semiestructurada y no estructurada. [...] Entrevista estructurada: [...] a esta entrevista también se le denomina entrevista directiva; se realiza a partir de un esquema o formato de cuestiones previamente elaborado, el cual se plantea en el mismo orden y en los mismos términos a todas las personas entrevistadas. [...] Las entrevistas requieren entrevistadores muy entrenados y que, a la vez, conozcan ampliamente el tema objeto de estudio".
} 
significa a infeliz interrupção dessas relações. "Jeitinho brasileiro" significa harmonizar os conflitos, driblar os obstáculos, usar uma certa falta de escrúpulos, truques que vão além das regras. [...] É atitude frequente também a tendência a considerar fluidos os limites entre o sagrado e o profano, entre o formal e o informal, entre o público e o privado, entre a emoção e a regra.

Além dos desafios de realizar a primeira edição sul-americana dos Jogos Olímpicos de Verão, o Brasil apresenta um cenário cultural que permeia a produção noticiosa com muito destaque para uma modalidade - o futebol - diante de outras que aconteceram simultaneamente nos Jogos. Some-se a isso, a perspectiva de geração de conteúdo informativo, ou melhor, da produção do material midiático, negociado sob contratos de direitos de transmissão, a partir do detentor, nesse caso, o Comitê Olímpico Internacional (IOC), juntamente com o organizador Comitê Olímpico do Brasil (COB).

A expectativa mais previsível, contudo, apontaria para uma cobertura com alto grau de detalhamento das modalidades olímpicas, preenchendo as lacunas de uma monocultura esportiva do "país do futebol" (MILAN, 1998). A própria especialidade do jornalismo destinado aos esportes também reflete o cenário cultural brasileiro, como explica o professor e pesquisador da Universidade Estadual Paulista Júlio de Mesquita Filho (Unesp), José Carlos Marques (2015):

\footnotetext{
$\mathrm{Eu}$ queria começar dizendo que não me agrada essa definição de jornalismo esportivo porque essa qualificação parece que diz que o jornalismo pratica esporte... Eu prefiro [estabelecer] uma iluminação [teórica] mais apropriada, a meu ver, que o jornalismo sobre esporte, sobre o fato esportivo, é algo que me agrada. Como é que eu definiria? É o jornalismo que se debruça sobre acontecimentos esportivos, especialmente o esporte de alta competição, de alto rendimento, o esporte competitivo. $\mathrm{O}$ jornalismo esportivo quase sempre, quase [que única e exclusivamente] vai se debruçar sobre o fato esportivo ligado a esses eventos do futebol [esporte] profissional.
}

A complexidade do tema se torna perceptível não apenas nos caminhos e divergências teóricas: no próprio jornalismo esportivo, a percepção individual e subjetiva caracteriza tal premissa. Professor da Universidade Federal de Juiz de Fora (UFJF), Márcio de Oliveira Guerra (2015) apresenta subsídios do âmbito teórico-prático sobre essa questão no jornalismo profissional brasileiro:

Jornalismo esportivo é uma atividade, uma editoria dentro do jornalismo, que tem a sua história marcada, primeiro, por um preconceito envolvendo a atividade, como se fosse uma atividade menor e que, aos poucos, foi se 
consolidando como um espaço cada vez mais legítimo e importante da prática de todas as teorias de comunicação, com elemento, um componente diferencial, porque nós lidamos com a paixão e com a emoção. E, por conta disso, o jornalismo esportivo ganha um impacto e uma projeção muito maior no público do que qualquer outra editoria, porque você mexe com aqueles que torcem a favor e torcem contra e, por conta disso, isso acaba causando sempre um impacto maior. Então, eu acho que o jornalismo esportivo é, acima de tudo, o exercício profissional feito com paixão.

Para o professor e pesquisador da Universidade do Estado do Rio de Janeiro (UERJ), Ronaldo George Helal (2015), o contexto cultural e social também contribui na definição dessa prática no Brasil:

Jornalismo esportivo é jornalismo. Talvez o que poderia diferenciar de outras editorias de esporte é que o jornalismo esportivo, talvez junto com o jornalismo de cultura, seriam editorias em que uma certa dimensão pelo gosto do objeto que está sendo informado é mais permitido, o que não é permitido, por exemplo, na seção de política. Ainda assim, existe uma tendência muito forte, hoje em dia, de o jornalismo esportivo se distanciar cada vez mais do seu objeto e procurar fazer um certo jornalismo mais investigativo. Mas, desde Mário Filho ${ }^{11}$, já havia essa ideia, essa permissão, de o jornalismo esportivo demonstrar um pouco mais a sua paixão pela atividade. Hoje, eu acho que isso vem diminuindo.

Neste ponto, o pensamento de Helal reflete um aspecto específico: um consenso histórico que pontua detalhes e características de uma deontologia do jornalismo esportivo. Isto contempla o trabalho do pesquisador e então professor da Universidade Católica de Santos (UCS), Ouhydes João Augusto da Fonseca (1981, p.18), na dissertação de mestrado O cartola e o jornalista: a influência da política clubística no jornalismo esportivo de São Paulo, defendida por ele na Escola de Comunicação e Artes (ECA) da USP:

Em realidade, não há muitas fontes de consulta do jornalismo esportivo, talvez em razão do seu aparecimento tardio, de sua condição de filho bastardo do jornalismo. Assim, a história do jornalismo esportivo mundial ultrapassa pouco mais de cem anos.

Para a jornalista e apresentadora da Rádio e Televisão Educativa de Campo Grande ${ }^{12}$, Eva Regina Freitas (2015), jornalismo e esporte fazem parte da vivência e do gosto motivacional:

\footnotetext{
${ }^{11}$ Mário Filho (1908 -1966) foi um jornalista esportivo. Até hoje é considerado uma referência na área.

${ }^{12}$ No período de agosto a dezembro de 2015, foi desenvolvido um estágio discente por meio do Programa de Cooperação Acadêmica (PROCAD), que possibilitou a realização de uma pesquisa em Campo Grande (MS), com recursos do Programa de Pós-Graduação em Comunicação da Universidade Federal do Mato Grosso do Sul (UFMS).
} 
Quando optei pelo jornalismo, eu não tive dúvida: eu queria o jornalismo esportivo e, apesar de ser complicado, por ser mulher, quando eu comecei existia isso [estigma]: a pessoa já olhar de uma forma diferente, porque você quer fazer o esporte: "e essa menina no meio de todo mundo, será que entende mesmo?", então você sentia certo receio, mas pelo fato de ser mulher, precisa provar [o valor profissional], mas sempre digo uma coisa: [no jornalismo esportivo] a mulher não pode errar. Se o homem errar, tranquilo... Agora, quando a mulher errou, no outro dia vai ser o comentário geral. Então, eu acho que isso já pesa mais, é uma responsabilidade a mais, mas isso eu vejo como uma coisa boa: porque preciso me esforçar mais... Para fazer o esporte, tem que gostar... Não tem jeito! Então, você vai atrás de notícias, você quer saber, quer ficar bem informado, o que está acontecendo. Também há muitos jornalistas. Por exemplo, aqui em Campo Grande, não fazem esporte, fazem futebol... Eu me interesso por todas, ou melhor, são várias as modalidades esportivas. Gosto do futebol, sempre fui apaixonada pelo futebol, mas acima de tudo, sou apaixonada pelo esporte.

Além disso, faz-se importante uma ressalva às nuances culturais dos aspectos brasileiros percebidos no processo de construção noticiosa do jornalismo esportivo, como relata o professor da USP, Manuel Carlos Chaparro (2015):

Eu sou um pouco contra os rótulos: acho que não existe jornalismo esportivo, existe jornalismo aplicado ao esporte, porque o jornalismo é a linguagem social e cultural mais adequada para socializar os discursos onde há conflitos e o esporte é essencialmente um ambiente de conflitos. Você não tem nada no esporte que não tenha a emoção do conflito. Então, o importante é levar para o esporte o jornalismo, com todas as suas exigências éticas, técnicas e culturais. É isso que interessa ao esporte: usar e ter que usar uma linguagem confiável. E o jornalismo é, se for respeitado como linguagem, também no esporte, um ambiente, um espaço público dos conflitos. As coisas acontecem não [apenas] no estádio. Acontecem à medida que o jornalismo socializa os discursos do embate.

Assim, as notícias esportivas dos Jogos Olímpicos Rio 2016 poderiam oferecer uma boa possibilidade de ampliação e envolver modalidades diferentes, cujas práticas são desconhecidas ou sem recorrência. Erbolato (1981, p.15) define a seção esportiva da seguinte maneira:

A editoria de esportes tem importância pela diversidade dos assuntos que aborda, nos setores profissional e amadorístico. Para cada especialidade recomenda-se um jornalista que entenda do assunto e que explique e comente a possibilidade dos concorrentes e as consequências de uma 
vitória, derrota ou empate em algumas competições.

Professor e pesquisador da Universidade Presbiteriana Mackenzie, Anderson Gurgel (2015) exemplifica essa questão:

Essa é uma das perguntas mais complicadas quando estudamos comunicação e esporte no Brasil, porque há um confronto entre alguns teóricos que já estudam o assunto e o que temos cotidianamente na mídia. Se tivermos aquilo que vemos nos jornais, nas revistas, na TV - como sendo "jornalismo esportivo" - vamos achar que praticamente é futebol e um pouquinho de automobilismo, um pouquinho de vôlei, basquete... É quase isso e, de vez em quando, aparece um tal de Gabriel Medina, uma Daiane dos Santos. Então, temos um problema na maneira como a mídia esportiva mostra o esporte. A mídia, o jornalismo esportivo, como se apresenta o esporte - esse é o primeiro ponto. Por outro lado, a teoria que fala desse assunto vai nos dizer que jornalismo esportivo, a princípio, tem a ver com todo um campo que envolve questões do esporte que tem valornotícia, que sejam objetos jornalísticos, que interessam ao público, que o jornalismo fará seu papel, como uma instância que vai organizar e levar informações para esse público.

Gurgel (2015) também deixa claro que a prática de muitas atividades simultâneas pelo jornalista pode causar confusão no trabalho desenvolvido por esse profissional:

Quer dizer: temos a ideia de que qualquer tema dentro desse universo esportivo que interessa a um público pode ser objeto do jornalismo esportivo e, por outro lado, o jornalismo esportivo feito na mídia, que é sempre voltado para o alto rendimento, abordando o futebol e um pouquinho de outras coisas. Esse é o problema: eu sou o defensor da ideia de que precisamos repensar o conceito de jornalismo esportivo cada vez mais, promovendo, efetivamente, um jornalismo que fale do esporte de uma forma total: mostra o esporte profissional, obviamente [de alto rendimento], mas também mostra o amador, o universitário, o esporte que inclui, o esporte que trabalha com a terceira idade, com as crianças, o esporte na educação. É essa a militância que venho desenvolvendo.

Ao considerar a inclusão das atividades físicas como um dos seus focos, a cobertura jornalística esportiva passaria a lidar com notícias que não abordassem apenas o resultado das partidas em si, mas que incluíssem fatos decorrentes, como os atletas, os treinamentos e, de modo indireto, o ambiente do incentivo ao próprio esporte. O professor da Escola de Educação Física e Esporte (EEFE) da USP, Ary Rocco Júnior (2015), aborda esse aspecto:

Jornalismo esportivo é uma especialização do jornalismo que especificamente trata - ou deveria tratar - de todas aquelas pautas relacionadas ao universo do esporte: prática esportiva, fomento ao esporte, megaeventos esportivos, competições esportivas, o atleta, o treinador; ou 
seja, todo aquele universo que efetivamente é responsável pelas modalidades esportivas e pelas competições esportivas em nível local, nacional, internacional e fomento do esporte.

A complexidade da definição do que seria o jornalismo esportivo no contexto da realização das Olimpíadas no Rio de Janeiro tornou fundamental buscar uma definição atualizada sobre essa prática profissional no Brasil. Professor da Universidade Federal do Mato Grosso do Sul (UFMS), João Jair Sartorelo (2015) inclui nesse rol de aspectos da contemporaneidade, como o embate entre as questões do imediatismo e a constante atualização versus estratégias de planejamento, a participação subjetiva e a necessidade de que o jornalista tenha mais envolvimento com os esportes e com as práticas frequentes do cotidiano:

O desafio da mídia para cobrir um evento olímpico deve ter um caráter idôneo, não pode ser levado por emoções e deve ter um senso crítico: ele não pode simplesmente criticar por criticar, ele deve apresentar os motivos das críticas e também dos elogios. No momento, há uma confusão: existem pessoas que fazem uma análise diferenciada entre esporte, desporto e atividade física... O importante é o ser humano se movimentar, praticar qualquer tipo de atividade.

Em Campo Grande, não existe um planejamento [olímpico] para daqui a alguns anos. O que existem são pessoas que têm interesse em fazer alguma coisa planejada, mas quando obtêm algo, não tem apoio de nada. É o atleta autodidata ou pai do atleta ou é algum benfeitor que aparece para auxiliar essas pessoas, mas que não tem condições de levar um projeto grande para frente.

Professor e pesquisador da Universidade de Sorocaba (Uniso), Felipe Tavares Paes Lopes (2015) evidencia os tópicos de complexidade percebidos no âmbito sociocultural ao problematizar os aspectos da grande imprensa:

Jornalismo esportivo, do meu ponto de vista, é aquilo que, de uma forma geral, é dito sobre o esporte nos mais diversos veículos e meios de comunicação. Se pegarmos o que está na chamada grande imprensa, hoje em dia, jornalismo esportivo é basicamente futebol, porque basicamente é aquilo que tem visibilidade nos meios de comunicação. Outra questão é aquilo que, na minha opinião, deveria ser o jornalismo esportivo. Já que ele é futebol e basicamente se configura como espaço de entretenimento e lazer. Evidentemente, do meu ponto de vista, seria interessante ocorrer uma diversificação e, mais do que isso, [que] houvesse algo além da politização - porque a própria despolitização é uma forma de politização -, mas seria interessante configurar esse espaço, não só da leveza, do entretenimento, mas configurar esse espaço de tal modo para que ele seja utilizado para que possamos pensar os significados e as funções sociais do esporte na sociedade contemporânea. 
Com isso, emerge a dúvida que relaciona tanto o planejamento dos eventos esportivos como a prática esportiva para além da vivência cotidiana do espectador que assistiu aos Jogos do Rio 2016. O espetáculo pressupõe qualidades positivas, como, por exemplo, divulgar e promover atividades físicas, bem como o lado mercantilizado, decorrente de ações de marketing provenientes do contexto dos esportes de alto rendimento. O conceito de espetáculo discorrido pelo filósofo francês Guy Debord (1997, p.42) revela indícios acerca de receios relacionados à possibilidade de ocorrência de erros na realização de megaeventos:

Sob as oposições espetaculares, esconde-se a unidade da miséria. [...] conforme as necessidades do estágio particular da miséria que o espetáculo nega e mantém, ele existe sob forma concentrada ou sob forma difusa. Em ambos os casos, ele não passa de uma imagem de unificação feliz cercada de desolação e pavor; ocupa o centro tranquilo da desgraça.

A cobertura olímpica no Brasil também possibilitou a reflexão sobre as dificuldades de transmissão dos Jogos Olímpicos. Por exemplo, houve casos em que a explicação sobre o funcionamento de outras modalidades fez referência ao futebol, principalmente. Isso leva a pensar também na necessidade de atualização da formação profissional do jornalista da área de esportes diante das possibilidades da tecnologia e da mídia convergente. A jornalista sul-mato-grossense Eva Regina Freitas (2015) sinaliza esse tipo de experiência:

\footnotetext{
O que existe também são muitos jornalistas, por exemplo, aqui em Campo Grande, que não fazem o esporte, fazem o futebol. Eu me interesso por todas, ou melhor, são várias as modalidades esportivas. Gosto do futebol e sempre fui apaixonada pelo futebol, mas, acima de tudo, sou apaixonada pelo esporte. Eu gosto de acompanhar o máximo que eu puder, mas, é lógico: ninguém sabe tudo de tudo. Quando faço uma matéria sobre determinada modalidade e alguma coisa [prática esportiva] que está começando eu sempre vou perguntar. E sempre falo: "pergunte, não tenha vergonha de perguntar, porque ninguém nasceu sabendo". Então, em um esporte novo: "como funciona?", "como é que marca ponto?", "quais são os principais lances?" - é preciso perguntar. E se não sei, eu vou perguntar mesmo! Eu acho que assim você está vivendo o esporte, fazendo o que gosta, e isso é muito mais legal.
}

Para o radialista e jornalista Arthur Mário Medeiros Ramalho (2015), da rádio Cultura AM de Campo Grande, a seção esportiva, além de exigir que o profissional mantenha seu repertório atualizado, apresenta-se como uma grande escola profissional: 
Do meu ponto de vista, o jornalismo esportivo no rádio é um verdadeiro caça-talentos para o jornalismo brasileiro. Quantos jovens iniciaram no rádio esportivo, inicialmente pela paixão e curiosidade? [...] O jornalismo esportivo, além de ser essa grande escola, também é o espaço de muita realização humana. Eu viajei o mundo e tive oportunidade de acumular tanto conhecimento, tanta informação nova nas viagens, carimbando meu passaporte pelo mundo afora que, se eu estivesse em outra área da comunicação, certamente não teria tido essa oportunidade de conhecer várias e várias culturas: América do Sul, Europa, Ásia. Então, há essa outra característica e o jornalismo esportivo dá uma bagagem diferenciada.

Chaparro (2015) traz uma percepção semelhante ao se referir tanto ao campo profissional como ao aprendizado do jornalismo:

Eu já fiz jornalismo esportivo, sou torcedor do Benfica e foi uma boa experiência [minha] do jornalismo esportivo porque, ao contrário de algumas outras áreas onde o jornalismo é usado, o esporte é um ambiente de atos e falas intensamente emotivos. Você sempre está participando quando escreve ou quando faz alguma coisa na área do esporte... Você sempre está participando de um ambiente muito amplo e emocional por causa do conflito.

A prática do jornalismo no Brasil que sediou os Jogos Olímpicos de 2016 apresentou várias nuances, levando-se em consideração a multiprodução de conteúdo informativo em diversos canais cibernéticos. Disso também decorreu uma sensação de escassez e caos por conta de conteúdos multifacetados, disponibilizados não apenas na mídia tradicional, mas também em nichos alternativos pela web. Muitos blogs e redes sociais, por exemplo, cobriram o evento destacando estritamente ao futebol. Enquanto isso, outras modalidades olímpicas permaneceram desconhecidas, com a visibilidade ofuscada.

A fim de contemplar a questão no âmbito internacional, especialmente em países europeus cujos idiomas e produtos midiáticos têm familiaridade junto aos brasileiros, incluiu-se nessa seção o professor espanhol Carlos Toural Bran, doutor em Ciências da Comunicação pela Universidade Santiago de Compostela (USC), na Espanha, que também atua como vice-decano e membro do Grupo de Pesquisa Novos Media da instituição.

Toural Bran dedicou parte dos seus estudos ao basquete na mídia espanhola e hoje desenvolve pesquisas sobre o perfil da comunicação digital a partir de novos formatos jornalísticos, convergência, arquitetura da informação, redes sociais e divulgação científica. A informação veiculada no ciberespaço por meio da utilização das mídias digitais - ou cibermídia - foi constatada por Xosé López García; Toural Bran e Moisés Limia Fernández (2010, p.03) como: 
[...] o conhecimento em torno da informação jornalística da internet que se encontra em edições online de jornais esportivos com edição nacional. Isto é, pretendemos determinar se os cibermeios galegos assumem e promovem as reivindicações da web social com relação a participação e interatividade, promovendo desse modo, uma relação de igual para igual com o usuário/leitor, ou então, se uma há sustento para uma percepção antiquada da atividade jornalística. (Tradução nossa) ${ }^{13}$

Toural Bran (2017) faz considerações referentes à questão que permeia a prática do jornalismo esportivo:

Creio que o jornalismo esportivo, de maneira essencial, é uma especialização da informação no âmbito dos esportes. Quero dizer, é uma especialidade que trata o assunto dos esportes a nível nacional. E também, numa segunda fase, a nível particular, há basicamente um vínculo entre a mídia e os esportes: digamos que funciona como uma especialização ideal que aborda especificamente esses dois temas. O jornalismo esportivo, realmente, nas últimas décadas, obteve muita importância pelas diferentes implicações que o esporte tem na sociedade a nível político e, sobretudo, econômico e social - já que o jornalismo esportivo tem uma grande capacidade para a criação de uma visão, digamos, "crítica" sobre determinadas questões. Deste ponto de vista, o jornalismo esportivo tornou-se um elemento essencial para a construção desses devidos debates.

Professor da Universidade Paulista (Unip), diretor e professor do Centro de Práticas Esportivas (CEPE) da USP, o pesquisador Pascoal Luiz Tambucci (2016) considera:

O jornalismo esportivo tem a preocupação de trabalhar notícias do esporte e, quando falamos desse assunto, também da própria modalidade esportiva: o que é, por exemplo, o futebol, o que é o voleibol, o que é o judô? $\mathrm{O}$ que tem por trás dessas mais de 40 modalidades que, de certa forma, podem suscitar interesses tanto do cidadão comum como daquele que se especializa em uma das áreas, que pode ser a comunicação, pode ser a educação física, pode ser o esporte ou uma empresa que está preocupada em promover atividades de entretenimento? O jornalismo esportivo tem que abarcar muitas questões relacionadas ao esporte de uma maneira geral porque o esporte tem forte apelo.

Tambucci (2016) ainda elenca outras qualidades do jornalismo esportivo:

\footnotetext{
${ }^{13}$ No original, em espanhol: “[...] la información periodística en Internet se hallan las ediciones en red de los diarios deportivos impresos de tirada nacional. Esto es, pretendemos determinar si los cibermedios gallegos asumen y fomentan los postulados de la web social en cuanto a participación e interactividad, promoviendo de este modo una relación de igual a igual con el usuario/lector, o por el contrario, se aferran a una concepción decimonónica de la actividad periodística”.
} 
Hoje, diferente de duas ou três décadas atrás, o esporte está muito marcado na cultura brasileira: o cidadão comum tem muito mais chances de praticar uma atividade física ou um esporte predileto porque isso já está fazendo parte de nossa cultura. Não que no passado não fizesse, mas agora está muito mais flexível, aberto, se encontram incentivos em diferentes lugares. E o jornalismo esportivo não deve apenas focar o esporte de rendimento - que são essas modalidades que ficam em evidência na mídia e que revelam grandes atletas e também grandes marcas que se apropriam do atleta para vender seus produtos - mas também atender um esporte amador, educacional que atua na formação do cidadão comum.

A percepção dos desafios da cobertura esportiva na contemporaneidade assinala, de modo enfático, o lugar de manifestação cultural dos brasileiros (LEVER, 1983) nos âmbitos cultural, socioeconômico e de saúde pública. As diferentes percepções sobre o conceito e a prática do jornalismo esportivo no interior do Brasil destacam os seguintes aspectos: o gosto pelo noticiário esportivo (HELAL, 2015), a expressão de emoções (GUERRA, 2015) e conflitos (CHAPARRO, 2015) na égide factual (MARQUES, 2015), voltado aos acontecimentos ocorridos no esporte (ROCCO JÚNIOR, 2015) que, na mídia, atinge a esfera do lazer e do entretenimento (LOPES, 2015) e a dimensão do espetáculo por meio dos megaeventos (CAMPOS, 2015).

Entretanto, não há diferença contextual da educação física no Brasil em relação aos termos esporte, desporto e atividade física (SARTORELO, 2015). A mudança assinalada na contemporaneidade ocorre com a disponibilidade, o acesso e a oportunidade de os brasileiros praticarem esporte (TAMBUCCI, 2016).

Um diferencial a ser compreendido no bojo desse questionamento relaciona o interesse e a prática dos esportes com a profissionalização dos jornalistas. Em Campo Grande, por exemplo, a curiosidade e a paixão (RAMALHO, 2015) acabam por motivar o esclarecimento e a prestação de informações de acordo com as regras específicas das modalidades (FREITAS, 2015).

No contexto espanhol, Toural Bran (2017) assinala a utilização de técnicas jornalísticas no registro da história local dos atletas. Neste caso, da região autônoma da Galiza:

[...] merece destaque que há vários volumes de reportagens e outros tipos de conteúdo de falam da 'Galiza Olímpica', ou seja, que contam a história desses atletas galegos que participaram das Olimpíadas. Principalmente, gostaria de mencionar uma sobre um aluno meu que foi escrita e publicada, creio que em 2016: foi um livro escrito por Álvaro Alonso com o título $A$ 
Galiza Olímpica: 1996 - 2016 $6^{14}$, que recolhe histórias, entrevistas e reportagens centradas nos atletas olímpicos galegos desse período e que serviu de continuação para outro livro que falava dos galegos nas Olimpíadas nos anos anteriores.

Pelo exposto, a maioria dos entrevistados associa o jornalismo esportivo a uma área em que a demanda por informações se encontra arraigada culturalmente nos âmbitos subjetivo e coletivo, cujo impacto inclui, ainda, a diversidade e o caráter informal das notícias, com ênfase no elemento humano.

Merece atenção também a influência do marketing esportivo, articulado na teoria do espetáculo, quando Debord (2003, p.14) pondera que "o espetáculo é ao mesmo tempo, parte da sociedade, a própria sociedade e seu instrumento de unificação". Isto ficou evidente na realização dos Jogos Olímpicos como um megaevento que, no Brasil, impactou outros dois pilares do momentum esportivo: o patrocínio à formação de jovens atletas e as obras de melhoria urbana na cidade-sede, o Rio de Janeiro.

\subsubsection{Em busca de um conceito de jornalismo esportivo}

Com base nas informações coletadas nas entrevistas sobre o que é jornalismo esportivo, se obtém o seguinte quadro, destacando o tema no contexto dos Jogos Olímpicos do Rio 2016:

Quadro 1 - Conceitos de jornalismo esportivo

\begin{tabular}{|c|c|}
\hline & O QUE É JORNALISMO ESPORTIVO? \\
\hline $\begin{array}{l}\text { Prof. Dr. } \\
\text { Manuel Carlos Chaparro } \\
\text { (USP) }\end{array}$ & $\begin{array}{l}\text { Jornalismo é a linguagem social e cultural mais adequada para socializar } \\
\text { os discursos onde há conflitos. O esporte traz a emoção dos conflitos. }\end{array}$ \\
\hline $\begin{array}{l}\text { Prof. Dr. } \\
\text { Ronaldo George Helal } \\
\text { (UERJ) }\end{array}$ & $\begin{array}{l}\text { Jornalismo esportivo é jornalismo. A seção, talvez junto com o } \\
\text { jornalismo de cultura, seriam editorias em que uma certa dimensão pelo } \\
\text { gosto do objeto que está sendo informado é mais permitido, o que não é } \\
\text { permitido, por exemplo, na seção de Política. }\end{array}$ \\
\hline $\begin{array}{l}\text { Prof. Dr. } \\
\text { José Carlos Marques } \\
\text { (Unesp) }\end{array}$ & $\begin{array}{l}\text { Não me agrada essa definição de jornalismo esportivo porque essa } \\
\text { qualificação parece que diz que o jornalismo pratica esporte... O } \\
\text { jornalismo esportivo vai se debruçar sobre o fato esportivo ligado a esses } \\
\text { eventos do esporte profissional. }\end{array}$ \\
\hline $\begin{array}{l}\text { Arthur Mário Medeiros } \\
\text { Ramalho } \\
\text { (Rádio Cultura, Campo } \\
\text { Grande) }\end{array}$ & $\begin{array}{l}\text { A curiosidade motiva o aprendizado do jornalismo. Jornalismo esportivo } \\
\text { no rádio é um caça-talentos. Ouvir grandes emissoras em uma cidade do } \\
\text { interior e se sentir atraído para o jornalismo esportivo: às vezes a vaidade } \\
\text { falando, às vezes a paixão falando... Na verdade, é essa grande escola de } \\
\text { jornalismo. }\end{array}$ \\
\hline
\end{tabular}

${ }^{14}$ FILGUEIRA, Álvaro Alonso. Galicia Olimpica: 1996 - 2016. Santiago de Compostela: Teófilo Comunicación, 2016. 


\begin{tabular}{|c|c|}
\hline $\begin{array}{l}\text { Prof. Dr. } \\
\text { Anderson Gurgel } \\
\text { (Mackenzie) }\end{array}$ & $\begin{array}{l}\text { Essa é uma das perguntas mais complicadas quando estudamos } \\
\text { comunicação e esporte no Brasil porque há um confronto entre alguns } \\
\text { teóricos que já estudam o assunto e o que temos cotidianamente na mídia. } \\
\text { Defendo a ideia de que precisamos repensar o conceito de jornalismo } \\
\text { esportivo, que fale do esporte de uma forma total: mostra o esporte } \\
\text { profissional, mas também mostra o amador, o universitário, o esporte que } \\
\text { inclui, o esporte que trabalha com a terceira idade, com as crianças, o } \\
\text { esporte na educação. }\end{array}$ \\
\hline $\begin{array}{l}\text { Prof. Dr. } \\
\text { Ary Rocco Júnior } \\
\text { (USP) }\end{array}$ & $\begin{array}{l}\text { Jornalismo esportivo é uma especialização do jornalismo que } \\
\text { especificamente trata ou deveria tratar de todas aquelas pautas } \\
\text { relacionadas ao universo do esporte: prática esportiva, fomento ao } \\
\text { esporte, megaeventos esportivos, competições esportivas, o atleta, o } \\
\text { treinador; ou seja, todo aquele universo que efetivamente é responsável } \\
\text { pelas modalidades esportivas e pelas competições esportivas em nível } \\
\text { local, nacional, internacional e fomento do esporte. }\end{array}$ \\
\hline $\begin{array}{l}\text { Prof. Dr. } \\
\text { Felipe Tavares Paes Lopes } \\
\text { (Uniso) }\end{array}$ & $\begin{array}{l}\text { O que está na chamada grande imprensa é aquilo que tem visibilidade } \\
\text { nos meios de comunicação: espaço de entretenimento e lazer. Seria } \\
\text { interessante ocorrer uma diversificação e algo além da politização - seria } \\
\text { interessante configurar esse espaço, não só da leveza, do entretenimento, } \\
\text { de tal modo para que ele seja utilizado para que possamos pensar os } \\
\text { significados e as funções sociais do esporte na sociedade contemporânea. }\end{array}$ \\
\hline $\begin{array}{l}\text { Eva Regina Freitas } \\
\text { (Rádio e TV Educativa, } \\
\text { Campo Grande) }\end{array}$ & $\begin{array}{l}\text { Relacionado à prática e vivência do esporte. Apaixonada pelo esporte: } \\
\text { quando faço uma matéria sobre determinada modalidade e alguma coisa } \\
\text { [prática esportiva], eu sempre vou perguntar... "pergunte, não tenha } \\
\text { vergonha de perguntar, porque ninguém nasceu sabendo". Então, em um } \\
\text { esporte novo, "como funciona?", "como é que marca ponto?", "quais são } \\
\text { os principais lances?"; precisa perguntar... Se não sei, eu vou perguntar. } \\
\text { Assim você está vivendo o esporte, fazendo o que gosta, é muito mais } \\
\text { legal. }\end{array}$ \\
\hline $\begin{array}{l}\text { Prof. João Jair Sartorelo } \\
\text { (UFMS) }\end{array}$ & $\begin{array}{l}\text { Aquilo que atrai toda a mídia nacional: evento. O desafio da mídia para } \\
\text { cobrir um evento olímpico não pode ser levado por emoções e deve ter } \\
\text { um senso crítico: deve apresentar os motivos das críticas e também dos } \\
\text { elogios. O importante é o ser humano se movimentar, praticar qualquer } \\
\text { tipo de atividade. }\end{array}$ \\
\hline $\begin{array}{l}\text { Prof. Dr. } \\
\text { Pascoal Luiz Tambucci } \\
\text { (USP) }\end{array}$ & $\begin{array}{l}\text { O jornalismo esportivo tem que abarcar muitas questões porque o esporte } \\
\text { tem forte apelo. Hoje o esporte está muito marcado na cultura brasileira: } \\
\text { o cidadão comum tem muito mais chances de praticar uma atividade } \\
\text { física ou um esporte predileto com a intenção de melhorar a qualidade de } \\
\text { vida, da condição física ou até aumentar a disciplina no dia a dia. }\end{array}$ \\
\hline $\begin{array}{l}\text { Prof. Dr. Márcio Guerra } \\
\text { (UFJF) }\end{array}$ & $\begin{array}{l}\text { É uma atividade, uma editoria dentro do jornalismo que tem a sua história } \\
\text { marcada, primeiro, por um preconceito envolvendo a atividade, como se } \\
\text { fosse uma atividade menor e que, aos poucos, foi se consolidando como } \\
\text { um espaço cada vez mais legítimo e importante da prática de todas as } \\
\text { teorias de Comunicação, com elemento, um componente diferencial, que } \\
\text { nós lidamos com a paixão, lidamos com a emoção. }\end{array}$ \\
\hline $\begin{array}{l}\text { Prof. Dr. } \\
\text { Carlos Toural Bran } \\
\text { (USC) }\end{array}$ & $\begin{array}{l}\text { O jornalismo esportivo, realmente, nas últimas décadas, obteve muita } \\
\text { importância pelas diferentes implicações que o esporte tem na sociedade } \\
\text { a nível político e, sobretudo, econômico e social, já que o jornalismo } \\
\text { esportivo tem uma grande capacidade para a criação de uma visão, } \\
\text { digamos, "crítica" sobre determinadas questões. Deste ponto de vista, o } \\
\text { jornalismo esportivo tornou-se um elemento essencial para a construção } \\
\text { desses debates. }\end{array}$ \\
\hline
\end{tabular}

Fonte: elaboração própria 
A constatação sobre os Jogos Olímpicos do Rio 2016 apresentar um desafio à cobertura das modalidades olímpicas, sobretudo, das que não possuíam semelhança com o futebol e, por conta disso, eram desconhecidas do público brasileiro. Outro dilema se referiu ao elemento que transcende o próprio esporte: o ofuscamento dos valores olímpicos (TUBINO, 2007) e do congraçamento.

A partir das falas dos entrevistados, observou-se que a complexidade do conceito do jornalismo esportivo na contemporaneidade, no Brasil, se deparou com diferentes recortes e possibilidades. Muito além dos trabalhos surgidos com a natureza da deontologia jornalística (ERBOLATO, 1981; AMARAL, 1982), o jornalismo esportivo e olímpico no Brasil de 2016, que contou com uma oportunidade singular de sediar um evento de natureza mundial, demonstrou fragilidade diante da hegemonia do futebol em relação a outras práticas desportivas.

\subsection{O desenvolvimento da pauta olímpica no Brasil}

O jornalismo nos Jogos Olímpicos Rio 2016 implicou na cobertura esportiva compreendendo tanto a realização das qualificações como o resultado final. A partir do cenário mencionado anteriormente, quando o futebol se estabeleceu nos noticiários como espaço para expressar os conflitos da sociedade e dos sentimentos da cultura brasileira (DAMATTA, 1986), torna-se pertinente uma questão ligada à produção jornalística: como está sendo desenvolvida a pauta olímpica no Brasil?

Abordar o desenvolvimento da pauta olímpica no Brasil não significa apenas ir além do futebol, mas também pensar como o ambiente da disputa e da rivalidade convive com o respeito, a amizade e a excelência dos atletas, permitindo transmitir o momento esportivo além dos resultados e das medalhas. Helal (2015) considera que:

O problema no Brasil, que tem praticamente uma monocultura esportiva, é que quando chegam os Jogos Olímpicos, os jornalistas que se dizem 'esportivos' não sabem o que comentar, porque eles são jornalistas de futebol e então, as editorias de esporte contratam ex-jogadores [ex-atletas] desses esportes para comentar aquilo que o jornalista dito 'esportista' não consegue comentar. Praticamente, eu vejo isso: uma lacuna muito grande com relação a outro esporte que não seja futebol. Futebol, talvez depois vai ter basquete, o vôlei e daí você começa a contratar profissionais daqueles esportes para poder comentar, para poder dar uma dimensão melhor, um entendimento, para os espectadores, sobre aquele esporte. 
Helal (2015) aproxima-se, assim, da ideia proposta por Lage (2014) sobre linha editorial. Neste caso, revela-se a demanda gerada pelo futebol, mesmo que se trate de um evento que possui dezenas de modalidades com a participação de atletas brasileiros. Segundo Lage (2014, p.31):

Quando a linha editorial está introjetada [ela é uma espécie de regra tácita do jogo], o debate concentra-se em torno de detalhes da confecção. Indicam-se fontes, produzem-se orientações para a apresentação, ilustração e complementação das matérias, o que pode envolver a mobilização de vários profissionais, de sucursais, correspondentes ou agências.

Para Chaparro (2015), a pauta olímpica no Brasil apresenta poucos indícios de independência editorial:

\begin{abstract}
A pauta esportiva, tratando dos Jogos Olímpicos, como quase todas as pautas de hoje, é movimentada e estimulada pelos interessados nos Jogos Olímpicos: as fontes geram os conteúdos e a pauta dos Jogos Olímpicos, na minha opinião, precisa ser um pouco mais crítica, ser menos reprodutora, embora não se deva rejeitar o discurso das fontes, porque as fontes são sujeitos do processo, são autores do conteúdo, dos fatos, mas é preciso que [aquilo] que as fontes dizem ao fazer e o que as fontes fazem ao dizer seja colocado num contexto dos conflitos, dos questionamentos. O jornalismo tem a vocação que não pode ser rejeitada: produzir a discussão pública a partir dos fatos.
\end{abstract}

O depoimento de Chaparro (2015) encontra ressonância na discussão da integridade do jornalista proposta pelo professor emérito da Universidade de Columbia, John Hohenberg (1981, p. 82), onde merece destaque a necessidade de o jornalista atentar à intransponibilidade da realidade diante de qualquer tentativa de distorcê-la ou desvirtua-la. Mário Erbolato (1981, p.15) também faz uma ressalva que aponta um caminho que valoriza a qualidade do jornalismo:

A independência do jornal e do repórter precisa ser mantida a todo custo, principalmente quando há excursões esportivas. Nenhum favor [hospedagem, pagamento de passagem e outros] deverá ser aceito. Há coberturas, como a das Olimpíadas, que exigem equipes de jornalistas de preferência integradas por repórteres que não dominem só a língua do país em que se realiza a competição, mas também outras línguas estrangeiras.

$\mathrm{Na}$ opinião de Guerra (2015), a abordagem olímpica no Brasil poderia ocorrer, de maneira sutil, desde os meios de comunicação com bastante audiência até a pesquisa 
universitária, como nos trabalhos acadêmicos:

\begin{abstract}
Alguns bons trabalhos estão sendo feitos inicialmente, já criando um ambiente para as Olimpíadas. Percebo, por exemplo, a emissora oficial, que é a Rede Globo, fazendo já nos seus telejornais vários retrospectos históricos, trabalhando com atletas, familiarizando o público com algumas modalidades esportivas. Eu mesmo, em Juiz de Fora, tenho um grupo de pesquisa onde estamos fazendo um trabalho com alunos: nós montamos um site onde nós temos a oportunidade de oferecer ferramentas aos jornalistas e estudantes de comunicação que estejam interessados na cobertura das Olimpíadas para conhecer a linguagem de esportes que nós normalmente não estamos habituados a acompanhar. Eu acho que, nesse momento, o jornalismo esportivo está fazendo, inclusive, uma pauta interessante que é de educar o público brasileiro para uma competição.
\end{abstract}

A especialização da mídia brasileira em uma modalidade - o futebol - e o tratamento das Olimpíadas como espetáculo (DEBORD, 1997) realçam características da realização de megaeventos. Entretanto, a realização dos Jogos no Brasil poderia ter como diferencial um tipo de ruptura com as expectativas tradicionais por ser um país emergente, latino-americano e o primeiro a sediar um espetáculo desse porte em área sul-americana.

Por conta de uma visibilidade desigual das modalidades olímpicas na mídia, Marques (2015) fez as seguintes constatações:

Eu diria que, sob alguns aspectos, [a pauta olímpica] não está sendo desenvolvida. Mas o esforço que eu tenho notado é o da emissora que detém os direitos da transmissão, a TV Globo, estar realizando várias reportagens didáticas para mostrar como são algumas modalidades esportivas, quais são as regras, quais são as características daquelas modalidades. Obviamente, porque ela está preocupada em poder "didatizar" o seu público, tendo em vista as competições que vão acontecer, no ano que vem, no Rio de Janeiro.

A cobertura das disputas mostra-se como uma noção revista, conceitualmente associada à maneira circunscrita pelo historiador holandês Johan Huizinga (2012), na primeira metade do século XX, ao encontrar na editoria de esportes do século XXI algumas reminiscências e respaldos da competitividade, em oposição aos ideais olímpicos da excelência, do respeito e da amizade. Entre as referências dispostas pelo trabalho de Huizinga (2012, p.55), destacam-se contribuições de natureza teórico-filosófica da 'teoria do jogo' introjetadas na cultura:

E a partir do momento em que um jogo é um espetáculo belo, seu valor cultural se torna evidente. Mas este valor estético não é indispensável para a cultura: os valores físicos, intelectuais, morais ou espirituais também são 
capazes de elevar o jogo até o nível cultural. Quanto maior é a sua capacidade de elevar o tom, a intensidade da vida do indivíduo ou do grupo, mais rapidamente passará a fazer parte da civilização.

Para Rocco Júnior (2015), aspectos paradoxais e inerentes à Olimpíada acabam incluídos na pauta olímpica no Brasil devido à sazonalidade (ou 'janela' olímpica). Enquanto o evento se aproximava, aumentavam as chances de a cobertura esportiva incluir a pauta olímpica no Brasil:

[...] a pauta do esporte, paradoxalmente, está muito mais voltada para a infraestrutura e discussão de legado... E a gente tem deixado de lado um pouco a [pauta de] preparação das equipes esportivas, a preparação das diversas equipes do Brasil para a competição. Eu diria que, nesse momento, a pauta esportiva está num segundo plano e no primeiro plano está a questão do legado e as questões políticas e sociais. Imagino que, com a aproximação dos Jogos Olímpicos e com as obras, os ginásios e as instalações começando a ficar de pé, essa pauta deva se deslocar um pouco mais da questão do legado para a questão da preparação das equipes brasileiras, das diferentes modalidades para a disputa dos jogos.

$\mathrm{Na}$ cobertura dos Jogos Olímpicos, aspectos organizacionais do evento como a construção de infraestrutura, planejamento e legado foram ocupando um espaço importante na mídia. Por sua vez, aquilo que ficava alheio ao contexto tinha chance de ser inferido na forma de complexos comportamentais (MASI, 2015), em tom jocoso (DAMATTA, 1986), com a percepção do brasileiro de que "vai dar errado". Segundo o professor Sartorelo (2015):

A mídia é levada por emoções: tem pessoas que se empolgam, tem pessoas que não se manifestam e eu acho que está tudo errado. "Mas se vai dar errado e não deixar legado nenhum?" [...] Acontece que todo evento esportivo sempre deixa um legado: seja bom ou ruim, mas deixa um legado. Hoje há um trabalho da grande imprensa para os Jogos Olímpicos de 2016: há uma preocupação muito grande com a segurança, com as condições dos locais dos Jogos e com a qualidade dos serviços prestados [...]. Em termos de gestão e execução, tudo que não é planejado acaba em fracasso. Isso implica que a preparação deve ser feita com muito tempo de antecedência, anterior ao evento, não em cima ou próximo dele, para que não tenhamos decepções no momento da competição.

Enquanto elemento cultural do Brasil destacado em 2016 apresenta características da preocupação do brasileiro em comparação com outras edições dos Jogos Olímpicos. Uma 
percepção sutil entre otimismo e pessimismo, assinalada pelo sociólogo Domenico De Masi

(2015, p. 222) remete à percepção cultural relacionada um complexo de inquietação:

O Brasil terá ainda, no futuro, uma população cilcotímica, oscilando entre a euforia - com a crença de ser o melhor país do mundo - e a depressão e o pessimismo, ou seja, entre o complexo de pit bull e o complexo de viralata. Essa mentalidade permanecerá como fruto da realidade de avanços e retrocessos: ditaduras e democracias, crescimento econômico e depressões, estabilidade monetária e inflação. O país será dado a polaridades, a comportamentos coletivos pendulares e, assim, manterá um espírito nacional dependente do instante histórico [...]. Dessa maneira, os críticos das mazelas do país serão atacados (como aconteceu na preparação para a Copa de 2014), mas [...] a autoestima do país, além disso, dependerá cada vez menos das conquistas do futebol ou da economia, concentrandose naquilo que se refletirá em qualidade de vida para as pessoas.

A questão do legado da cobertura do jornalismo esportivo das Olimpíadas do Rio de Janeiro 2016 também se tornou parte do debate entre pesquisadores de comunicação. Gurgel (2015) revela:

Há um desafio muito grande quando falamos sobre como pensar o jornalismo esportivo - amplo, total - que possa mostrar o esporte de maneira mais abrangente, que passa promover a cultura olímpica de outro modo e não focado somente em uma visão de resultado porque o Brasil, por muito tempo, foi o 'país do futebol', havia resultados e, consequentemente, só interessam os esportes em que o Brasil aparece bem e aí não se promove uma cultura na qual, às vezes, você tem que começar um processo. Se não há uma tradição em determinado esporte, é preciso um tempo, é necessário participar, ter contato com os atletas melhores que você. E para um país que valoriza excessivamente a vitória, isso é muito difícil. Há uma série de questões do conceito de olimpíada que precisam ser melhor trabalhadas para que o jornalismo esportivo brasileiro faça, realmente, um jornalismo olímpico de qualidade.

A ocorrência de novas possibilidades associadas a alguns aspectos da mídia digital, principalmente à seção considerada social que envolve blogs, Twitter e Facebook, apresentou situações inéditas no cotidiano brasileiro, como o registro da presença do público em postagens nas redes sociais ${ }^{15}$. Ou seja: publicação de material que enfatizava a presença do espectador na Olimpíada do Rio de Janeiro 2016 em registro audiovisual multimidiático. Como exemplo, não se pode fazer uma fotografia de primeira pessoa (selfie) na arquibancada, de frente para o evento, mas apenas em meio a outras pessoas que o assistem.

\footnotetext{
${ }^{15}$ Documento que descreve em detalhes as diretrizes recomendadas para as mídias sociais, publicado pelo IOC, em 2015. Traduzido e disponibilizado posteriormente no site do COB. Disponível em: <https://www.cob.org.br/Handlers/RecuperaDocumento.ashx?codigo=4539>. Acesso em: 26 jun. 2016.
} 
Mestre em Comunicação e Cultura, Daniela de Paula (2015, p.37) reflete sobre isso: "cotidiano e selfie são categorias que aparecem com frequência nas imagens compartilhadas pelos usuários-interatores".

Ramalho (2015) aborda a transmissão dos Jogos Olímpicos tanto pelo viés local, de Campo Grande, como por um modelo de credenciamento que resulta em um jornalismo desigual quando os 'não credenciados' ficam impedidos trabalhar:

Nos anos 90, nós, do jornalismo do interior, do rádio esportivo, enfim, tínhamos uma facilidade muito maior na cobertura dos eventos internacionais. Eu cobri, nos anos 90, duas Copas do Mundo, em parceria com a emissora local, de Campo Grande, com a equipe do Sistema Globo de Rádio, a equipe do Osmar Santos, cuja cobertura tinha produtos: boletins, jornada esportiva... Mas de lá, também, do evento, utilizando o canal da própria [rádio] Globo ou via LP [linha privada]: telefone - não era telefone celular ainda! Havia a possibilidade de cobertura, no mínimo, dois ou três jornalistas de rádio aqui de Campo Grande: eu, Rui Pimentel, Pereira Guedes, Pierre Adri. Fazíamos cobertura de eventos internacionais: Copa do Mundo, Jogos Olímpicos, enfim, Copa América de Futebol. Houve uma transformação e uma dificuldade imensa. Está muito mais difícil hoje, para o rádio do interior do País, em função dos direitos, dos custos e das dificuldades. A cobertura dos Jogos Olímpicos, por exemplo, eu cobri as Olimpíadas de Londres 'não credenciado' oficialmente porque eu perdi o prazo. Para essas Olimpíadas aqui no Brasil, o meu credenciamento foi negado. Então, nós vamos para a cobertura buscar uma parceria com uma grande emissora, com uma rede nacional e tentar uma cobertura paralela, 'não credenciada', por exemplo, para focar os nossos atletas de Mato Grosso do Sul em diversas modalidades esportivas [...]. Agora, cada vez mais, com esse país continental, com o tamanho que é o Brasil que as coisas, "esportivamente" estejam acontecendo somente a nível de São Paulo e Rio. Esse é um grave problema do nosso País: quem manda é São Paulo e Rio. O interior do país nem sempre, com algumas exceções, do Nordeste, do Sul, enfim [...]. Não só nessa pauta esportiva, mas de um modo geral. Nós somos reféns das grandes redes e da centralização das comunicações de São Paulo e Rio [...]. Ficamos um tanto preocupados. Gostaríamos de estar lá, credenciados oficialmente; vamos ter que fazer uma 'cobertura pirata', como o meu mestre e guru Josino Theodoro [da Silva] ${ }^{16}$ dizia. Quando não estamos credenciados, vamos, na base da pirataria, tentar suprir as informações para os nossos ouvintes.

Nessa perspectiva, faz-se importante a consideração da manifestação das emoções para além da apuração dos fatos, cujo impacto no desenvolvimento das pautas das especificidades olímpicas no Brasil suscita uma aproximação com o regional. Hohenberg (1981, p.280) afirma que a produção noticiosa não se restringe a locais com menos ou mais liberdade, pois a notícia ocorre em diferentes situações. Dessa forma, ele recomenda os

\footnotetext{
${ }^{16}$ Josino Theodoro da Silva (1930-2013) foi um jornalista com importante atuação no Mato Grosso do Sul.
} 
seguintes cuidados na produção noticiosa:

A ação de julgar entre a verdade e a falsidade tem sido uma questão ingrata e quase que impossível [...]. Poucos repórteres têm a liberdade de movimentos e o luxo de dispor de semanas e generosa quantia para apurar os fatos. Apurações básicas podem ser feitas, entretanto, por qualquer repórter empenhado em se esforçar em tais investigações.

A perspectiva de geração de conteúdo informativo, ou melhor, da produção do material midiático - negociado sob contratos de direitos de transmissão a partir do detentor (nesse caso, o COI, juntamente com o COB) - e a dinâmica dos compartilhamentos acabam entrando em conflito com padrões em que se observam:

- Normatização para a oferta de serviços de ponta disponíveis em economias desenvolvidas em escala adaptada;

- Serviços de telefonia móvel no padrão $4 \mathrm{G}$ em frequência diferente, o que tornou dispositivos disponíveis no exterior incompatíveis com aparelhos produzidos no Brasil;

- Regulamentação do aplicativo de telefones móveis, como o Uber, antes da realização dos Jogos Olímpicos de 2016, cuja discussão deixou de contemplar questões intrínsecas da defasagem de tecnologias ofertadas no Brasil, com alto preço dos serviços nacionais e modelos econômicos por meio de novas plataformas ${ }^{17}$.

Freitas (2015) considera que os acontecimentos do esporte olímpico contribuem para a promoção de aspectos regionais: atletas, cidades próximas e a prática de modalidades em outros locais, além da cobertura de categorias de base:

Quem faz o jornalismo esportivo já começa a falar em Olimpíada muito antes: a próxima [de 2016] vai ser no Brasil e já começamos a pensar em como vai ser. Eu gosto muito das categorias de base: gosto muito de saber como os nossos atletas estão. Aqui em Mato Grosso do Sul temos um judô forte, uma das coisas que eu gosto de dizer, porque tudo começou na base, um trabalho que começou há muitos anos. Isso é bacana de você acompanhar como está a nossa base não só no judô, em várias modalidades, de saber como está. Eu acho que você começa um bom trabalho por aí, ainda mais com uma Olimpíada vindo para o Brasil. Daí, tentamos buscar não só o lado do atleta, mas "como é que está a expectativa?", "quem vai assistir?", "como é que fica?". Isso incentiva

17 Site G1: "Justiça do Rio decide que serviço do Uber não pode ser proibido. Disponível em: $<$ http://g1.globo.com/rio-de-janeiro/noticia/2016/04/justica-do-rio-decide-que-servico-do-uber-nao-pode-serproibido.html>. Acesso em: 28 set. 2016. 
muito o esporte e percebemos que toda vez quando, principalmente, o Brasil consegue bons resultados. Então você vai lá [entre] as crianças, adolescentes e [isso] incentiva bastante a prática esportiva e sabemos que não [há] só os atletas de alto rendimento, mas também tem o esporte como lazer e sabemos os benefícios que isso traz para a saúde. Então, é muito importante esse incentivo ao esporte. Começamos a trabalhar a Olimpíada assim, eu acho, vendo como ela movimenta todo o País: é no Rio, mas vai respingar uma coisa para cá, por exemplo, alguém vem para o Rio, mas vai querer conhecer Bonito, vai querer conhecer o Pantanal... Então alguma coisa vai movimentar também e são inúmeros os benefícios: é o incentivo ao esporte, à economia do País. Percebendo esses benefícios, fico muito feliz, orgulhosa de ver crianças, de ver bons resultados nas categorias de base. Sou apaixonada pelas categorias de base porque é o futuro do nosso esporte que está em jogo.

Gurgel (2015), por sua vez, menciona aspectos dos desafios da cobertura no Brasil, destacando a pauta olímpica como:

Bastante claudicante, vamos dizer assim, usando uma palavra apropriada. Vem sendo desenvolvida de uma maneira que mostra a nossa dificuldade, enquanto um país que vai ser sede de uma Olimpíada, mas que não é potência olímpica. Temos uma cultura futebolística e a causa da Olimpíada não se mostra de igual força. Assim, tem esse problema que, agora que o evento se aproxima, vai aparecer mais, só que enquanto tinha uma Copa do Mundo [em 2014] no cenário, a Olimpíada praticamente não existia. Mas, efetivamente, em primeiro lugar, há uma contaminação do futebol: o filtro do futebol para olhar para outras coisas, para comparação, para tentar entender os esportes. O brasileiro tem uma tendência natural para o futebol e, praticamente, todos os outros esportes são olhados a partir desta janela, daí alguns são mais estranhos, mais exóticos, outros são mais ‘familiarizáveis' ou próximos por causa disso.

Para Lopes (2015), o desenvolvimento da pauta olímpica no Brasil ocorre da seguinte maneira:

[A pauta olímpica] não é meu objeto de estudo, mas como um leitor que gosta de ler esportes, me parece que a mídia, de forma geral, vem retratando as Olimpíadas como retrata os outros campos sociais, como a Política. Ou seja, ela retrata de forma espetacularizada, sem trazer reflexões mais aprofundadas acerca, por exemplo, do próprio papel e significado das Olimpíadas. Isso, me parece que não é colocado em pauta, que não é discutido nos meios de comunicação, pelo menos na chamada grande imprensa. Basicamente, me parece que é isso.

Tambucci (2016) leva em consideração os seguintes fatores internos e externos à tipificação do local: 
Eu vou tentar dar uma ideia daquilo que eu vejo, como se percebe ao se comparar o Brasil com outros países que tiveram oportunidade de sediar uma etapa dos Jogos Olímpicos, considerado como um dos eventos mais importantes do mundo pela mobilização que se dá em relação aos cinco continentes, aos diferentes países, ao que propicia em relação à economia, à cultura de um país... Porque a oportunidade de sediar faz com que o país se mostre e, ao mesmo tempo, permite que outras culturas venham ao Brasil, para partilhar características daqueles que vieram para apreciar a cultura brasileira, vieram assistir ao vivo a edição dos Jogos Olímpicos. Existem muitas contribuições que uma edição de Jogos Olímpicos traz para um determinado país. Muitas vezes, como já disse o renomado Moragas ${ }^{18}$, um professor consagrado na Europa e que também é jornalista: os Jogos Olímpicos, para muitos países, são a única oportunidade de se mostrar para o mundo em função da grande abrangência, da cobertura que se dá. Então, muitos países, por meio de suas cidades, se candidatam porque é uma oportunidade de mostrar a sua cultura, seu povo, suas características e muitas outras questões. Para fazer uma análise daquilo que o Brasil está fazendo, é preciso considerar o que foi feito por outros países: alguns fizeram trabalhos que são marcantes, de forma positiva e, claro, sempre tem coisas negativas - e o Brasil também vai passar por isso. Algumas coisas são extremamente positivas e outras são negativas, mas isso faz parte do dia a dia de qualquer tipo de empreendimento, de qualquer tipo de evento, de qualquer tipo de situação do dia a dia e no Brasil sempre haverá essa questão.

Eu sempre me lembro de um grande exemplo, que foi a edição dos Jogos de Barcelona [em 1992], que é considerada uma das mais importantes e uma das mais marcantes das edições da era moderna, desde 1896, porque a mobilização feita na Espanha, principalmente em Barcelona, foi tão grande que, na realidade, o povo queria a edição dos Jogos Olímpicos - e isso não se vê aqui no Brasil. Deve-se respeitar, por exemplo, o tamanho do Brasil em relação à Espanha, a tradição do Brasil, com relação a eventos de grande repercussão. Hoje, um dos eventos mais importantes talvez seja a Fórmula 1, que dá uma visibilidade muito grande para o País, mas o nosso Brasil ainda não tem uma tradição de fazer grandes eventos internacionais, como os países da Europa. Fazer uma comparação não é fácil, mas vale a pena dizer que "o povo de Barcelona queria a realização dos Jogos" e aqui, essa percepção pela mídia, pelos comunicadores, a partir daqueles que trabalham no sentido de promover os Jogos no Brasil, ainda não está tão marcada neste momento do final do mês de março [de 2016] até se concretizar na realização marcada para agosto. Então, se percebe que em outros lugares, de acordo com a proximidade do evento, a sociedade já estava mobilizada no sentido de aproveitar e falar sobre o evento, de ficar na expectativa da realização desse evento, de discutir da mesma maneira que se fala nos bares sobre uma partida de futebol. A ideia era que isso também estivesse acontecendo em relação às diferentes modalidades representada por atletas brasileiros - e nós temos muitos campeões, temos muitos valores, muita gente importante. Essa questão da receptividade do evento em si, ainda está a desejar, mas entendemos que com o tempo, isso irá se consolidar em função da própria característica do Brasil, pelas dimensões que ele tem. Os Jogos estão sendo noticiados, mas com muito pouca informação sobre infraestrutura, aspectos culturais do Brasil, que já poderiam ser trabalhados para vender uma imagem que, talvez, mostre

\footnotetext{
${ }^{18}$ Miguel de Moragas Spà (1943-) é um sociólogo e catedrático emérito da Universidade Autônoma de
} Barcelona. 
mais os valores da cultura brasileira, a exemplo de outros países, isso permitiria que pessoas que tivessem expectativas de vir ao Brasil para assistir aos Jogos, as informações sobre as cidades brasileiras com características marcantes, talvez isso incentivasse mais ainda a divulgação de forma internacional, mais abrangente pelos continentes, em outros países e, evidentemente, notícias mais positivas.

Toural Bran (2017) menciona como se desenvolveu a pauta olímpica no âmbito da mídia da comunidade autônoma da Galiza e espanhola:

Sobre desenvolvimento da pauta olímpica abordada pelo jornalismo esportivo, no caso da Galiza, existem determinadas especialidades esportivas que aqui se encontram relacionadas a grandes atletas e, respectivamente, com as modalidades. Temos a canoagem e David Cal e outras especialidades, digamos àquelas que somos potência.

Considerando-se a fala de Toural Bran (2017), entende-se que a mídia galega e espanhola apresentou coincidências com o noticiário esportivo brasileiro: destaque para modalidades e atletas tomados como favoritos à medalha e a derradeira percepção da 'janela' olímpica, quando as informações das categorias de base e o treinamento de atletas perde espaço para notícias sobre campeonatos de futebol local e europeu.

Considera-se, em particular, os elementos da cultura brasileira ao apresentar resquícios dessa premissa cujo impacto incide na necessidade de o jornalista esportivo ampliar sua atuação junto a outras modalidades olímpicas, especialmente quando a ocorrência e a produção noticiosa em função do local, nesse caso, o Rio de Janeiro.

Outro ponto que chama a atenção: como o desenvolvimento da pauta olímpica no Brasil entra em conflito com dois mundos opostos e que convivem no noticiário - o primeiro encontra-se atrelado aos lemas e ideais olímpicos - excelência, amizade e respeito - e o outro, incutido nos torneios esportivos de âmbitos que variam do local ao global, com respaldo na 'teoria do jogo' (HUIZINGA, 2012) e na cultura do 'jeitinho brasileiro' (DAMATTA, 1986).

No Brasil, a questão se reveste de complexidade por conta da transmissão de eventos esportivos: os torneios e as competições apresentam uma frequência previsível entre os semestres, cuja alternância se adapta ao cronograma dos esportes apresentados na mídia. $\mathrm{Na}$ contramão, a intermitência das Olimpíadas (a cada quatro anos) e o ciclo itinerante internacional relevam por que essa cobertura se distancia da comunicação mais presente no cotidiano. 
Segundo os entrevistados, a pauta olímpica relativa aos Jogos do Rio de Janeiro em 2016 estava sendo desenvolvida por meio de uma monocultura esportiva baseada no futebol (HELAL, 2015); de alguns esforços da emissora de televisão detentora dos direitos de transmissão dos Jogos (Rede Globo) para mostrar alguns esportes (MARQUES, 2015); por uma cobertura alternativa e paralela pelas emissoras do interior do Brasil (RAMALHO, 2015) e por acadêmicos (GUERRA, 2015); conduzida por um paradoxo entre o legado e a preparação das equipes e atletas (ROCCO JÚNIOR, 2015) retratada sem discussão, similar às outras editorias como a de política (LOPES, 2015), guiada pelas emoções e preocupada com a segurança, condições e qualidade dos locais das competições (SARTORELO, 2015), com picos de informação no exterior (TOURAL BRAN, 2017). Dessa forma, a cobertura precisa reproduzir a cultura olímpica (GURGEL, 2015) e, por ser mais crítica e menos reprodutora (CHAPARRO, 2015), torna-se essencial ao jornalista vivenciar o esporte (FREITAS, 2015). Por fim, a cobertura olímpica fica marcada pelo trabalho realizado, seja por aspectos positivos ou negativos (TAMBUCCI, 2016).

A partir das entrevistas sobre como está sendo desenvolvida a pauta olímpica no Brasil, emerge o seguinte quadro:

Quadro 2 - A pauta olímpica COMO ESTÁ SENDO DESENVOLVIDA A PAUTA OLÍMPICA NO BRASIL?

\begin{tabular}{|l|l|}
\hline $\begin{array}{l}\text { Prof. Dr. } \\
\text { Manuel Carlos Chaparro } \\
\text { (USP) }\end{array}$ & $\begin{array}{l}\text { Pauta movimentada pelos interessados nos Jogos Olímpicos: as fontes } \\
\text { geram os conteúdos e a pauta. Em minha opinião, precisa ser um pouco } \\
\text { mais crítica e menos reprodutora. }\end{array}$ \\
\hline $\begin{array}{l}\text { Prof. Dr. } \\
\text { Ronaldo George Helal } \\
\text { (UERJ) }\end{array}$ & $\begin{array}{l}\text { Monocultura esportiva. Quando chegam os Jogos Olímpicos, os } \\
\text { jornalistas que se dizem "esportivos" não sabem o que comentar porque } \\
\text { eles são jornalistas de futebol. Uma lacuna muito grande com relação a } \\
\text { outro esporte que não seja futebol. }\end{array}$ \\
\hline $\begin{array}{l}\text { Prof. Dr. } \\
\text { José Carlos Marques } \\
\text { (UNESP) }\end{array}$ & $\begin{array}{l}\text { Em muitos aspectos, não está sendo desenvolvida. Esforços da emissora } \\
\text { que detém os direitos de transmissão dos Jogos (Rede Globo), que realiza } \\
\text { matérias didáticas para mostrar como são algumas modalidades } \\
\text { esportivas, quais são as regras e características. }\end{array}$ \\
\hline $\begin{array}{l}\text { Arthur Mário Medeiros } \\
\text { Ramalho } \\
\text { (Rádio Cultura, Campo } \\
\text { Grande) }\end{array}$ & $\begin{array}{l}\text { No jornalismo do interior, há dificuldade de cobertura dos eventos } \\
\text { internacionais devido aos direitos de transmissão. Na cobertura, buscar } \\
\text { uma parceria com uma grande emissora e uma cobertura paralela (não } \\
\text { oficial) com os atletas do Mato Grosso do Sul em diversas modalidades } \\
\text { esportivas. Necessidade da cobertura alternativa para tentar suprir as } \\
\text { informações para os ouvintes. }\end{array}$ \\
\hline $\begin{array}{l}\text { Prof. Dr. } \\
\text { Anderson Gurgel } \\
\text { (Mackenzie) }\end{array}$ & $\begin{array}{l}\text { Desenvolvimento claudicante, que mostra uma dificuldade: um país que } \\
\text { sedia uma Olimpíada, mas não é potência olímpica. Temos uma cultura } \\
\text { futebolística e a causa da olimpíada não se mostra de igual força. Há uma } \\
\text { contaminação do futebol (filtro e tendência natural para o futebol). Há } \\
\text { um desafio muito grande, que possa mostrar o esporte de maneira mais } \\
\text { abrangente para promover a cultura olímpica, que necessita do começo } \\
\text { de um processo: atletas, tradição em outras modalidades olímpicas. } \\
\text { Questões do conceito de Olimpíada que precisam ser mais bem }\end{array}$ \\
\hline
\end{tabular}




\begin{tabular}{|c|c|}
\hline & $\begin{array}{l}\text { trabalhadas (excelência versus valorização das vitórias) para que o } \\
\text { jornalismo esportivo brasileiro faça um jornalismo olímpico de } \\
\text { qualidade. }\end{array}$ \\
\hline $\begin{array}{l}\text { Prof. Dr. } \\
\text { Ary Rocco Júnior } \\
\text { (USP) }\end{array}$ & $\begin{array}{l}\text { No momento (2015), a pauta, paradoxalmente, está restrita à questão do } \\
\text { legado dos Jogos e tem deixado de lado a preparação das equipes e atletas } \\
\text { do Brasil. Com a aproximação dos Jogos Olímpicos e a conclusão de } \\
\text { obras, a pauta se desloca da questão do legado para a preparação dos } \\
\text { atletas. }\end{array}$ \\
\hline $\begin{array}{l}\text { Prof. Dr. } \\
\text { Felipe Tavares Paes Lopes } \\
\text { (Uniso) }\end{array}$ & $\begin{array}{l}\text { A mídia vem retratando as Olimpíadas da mesma forma que retrata os } \\
\text { outros campos sociais, como a política. Parece que não é colocado em } \\
\text { pauta, não é discutido na chamada grande imprensa. }\end{array}$ \\
\hline $\begin{array}{l}\text { Eva Regina Freitas } \\
\text { (Rádio e TV Educativa, } \\
\text { Campo Grande) }\end{array}$ & $\begin{array}{l}\text { Vivência do esporte: quem faz jornalismo esportivo já começa a falar em } \\
\text { Olimpíada muito antes. Acompanhar categorias de base, onde o futuro } \\
\text { do esporte está em jogo. Tentamos buscar não só o lado do atleta, mas } \\
\text { também como a expectativa. Respingos do Rio de Janeiro: turistas vêm } \\
\text { para o Rio e acabam visitando Bonito e o Pantanal sul-mato-grossense. }\end{array}$ \\
\hline $\begin{array}{l}\text { Prof. João Jair Sartorelo } \\
\text { (UFMS) }\end{array}$ & $\begin{array}{l}\text { A mídia se leva pelas emoções. Na questão do legado, todo evento } \\
\text { esportivo sempre deixa legado, seja bom ou ruim. Existe a preocupação } \\
\text { com a segurança, sobre as condições dos locais dos Jogos e a qualidade } \\
\text { dos serviços prestados. }\end{array}$ \\
\hline $\begin{array}{l}\text { Prof. Dr. } \\
\text { Pascoal Luiz Tambucci } \\
\text { (USP) }\end{array}$ & $\begin{array}{l}\text { O que está e foi feito será marcado (negativa ou positivamente) pelos } \\
\text { trabalhos durante o evento. É complicado comparar o Brasil com outros } \\
\text { países da Europa. Devemos respeitar o tamanho do Brasil em relação a } \\
\text { outros países, que realiza outros eventos de repercussão, como Fórmula } \\
1 \text {. }\end{array}$ \\
\hline $\begin{array}{l}\text { Prof. Dr. Márcio Guerra } \\
\text { (UFJF) }\end{array}$ & $\begin{array}{l}\text { Alguns bons trabalhos estão sendo feitos inicialmente (2015). A emissora } \\
\text { oficial, a Rede Globo, faz nos telejornais vários retrospectos históricos, } \\
\text { trabalhando com atletas e familiarizando o público com algumas } \\
\text { modalidades esportivas. Em Juiz de Fora, estamos fazendo um trabalho } \\
\text { com os alunos: montamos um site onde oferecemos ferramentas a } \\
\text { jornalistas e estudantes de comunicação interessados na cobertura das } \\
\text { Olimpíadas. }\end{array}$ \\
\hline $\begin{array}{l}\text { Prof. Dr. } \\
\text { Carlos Toural Bran } \\
\text { (USC) }\end{array}$ & $\begin{array}{l}\text { Em relação à mídia e aos esportes olímpicos, creio que na Galiza não } \\
\text { houve um movimento permanente e constante ao redor do olimpismo. } \\
\text { Basicamente, o que se deu foram picos de informativos relacionados com } \\
\text { as prévias das Olimpíadas e o desenvolvimento dos Jogos. Também } \\
\text { acontece com a informação posterior, mas muito voltada às Olimpíadas. } \\
\text { Porém, após o ciclo olímpico, não se mantém uma produção de conteúdo } \\
\text { informativo em relação a esses esportes. }\end{array}$ \\
\hline
\end{tabular}

Fonte: elaboração própria

Nas entrevistas, a pauta olímpica foi apontada como um desafio para a cobertura jornalística esportiva devido às características culturais brasileiras, onde se destacam, por um lado, a ausência de contato com boa parte das modalidades olímpicas e, por outro, uma quase monocultura esportiva centrada no futebol.

O capítulo a seguir busca elucidar esta questão a partir do Comitê Olímpico do Brasil, por meio de um estudo de seu website e das entrevistas com jornalistas que atuam no COB e também cobriram os Jogos do Rio de Janeiro em 2016. 


\section{MÍDIAS DIGITAIS E O SITE DO COMITÊ OLÍMPICO DO BRASIL}

Este capítulo tece considerações sobre as mídias digitais tendo em vista compreender o funcionamento e os objetivos do site do Comitê Olímpico do Brasil. O ato de acessar e produzir informações na internet atingiu distintos protagonismos nas pesquisas acadêmicas. Entre as abordagens sobre a utilização de padrões numéricos, coloca-se em discussão a transmissão e a recepção de dados codificados por procedimentos algébricos, ou seja, como equações e sequenciamentos matriciais vertem as informações de textos, imagens, sons e diálogos em dados numéricos. Esses dígitos constituem numerais que formam o registro sequencial da informação que, para ser acessada, precisa ser codificada e decodificada (HALL, 2003) em padrões específicos.

De forma recorrente, nos estudos de Comunicação, assinala-se a adoção do termo analógico como o sinônimo de processamento de informações que não são convertidas em números. Professor da Universidade Federal do Rio Grande do Sul, Francisco Ricardo Rüdiger (2007, p.79) destaca que esse tema possui aspectos positivos e negativos. O processo de comunicação mostra-se subdividido entre ranhuras das redes e sucessivas interações que ocorrem pela respectiva sequência: sujeitos e dispositivos que realizam a conversão de números em informações (ou homem-máquina) e entre os equipamentos na rede.

Rüdiger (2007, p.16) exemplifica limiares que tangenciam a perspectiva filosófica inspirada na técnica:

Chamando de pensamento tecnológico a essa forma de enfrentar o assunto, pode-se resumir seu entendimento a respeito, dizendo que, para ele, a tecnologia exerce uma grande influência, a principal, no destino da humanidade e que o progresso da técnica tem um cunho em última instância independente relativamente a outros fatores intervenientes na vida em sociedade.

A convicção de que a atividade técnica determina o curso de nossa existência não é, porém, uniforme no plano das opiniões acerca do seu significado.

Em consideração a essa observação e às várias vertentes das abordagens das práticas culturais no ciberespaço, faz-se necessário um recorte em torno das vertentes abordadas neste capítulo: a convivência, utilização e enraizamento social de serviços digitais pela web. A partir dessa convivência com as tecnologias, existem articulações referentes às 
possibilidades latentes de as ferramentas cibernéticas levarem em consideração os ensaios desenvolvidos pelo professor e filósofo Pierre Lévy (1999), com desdobramentos articulados às práticas jornalísticas a partir dos trabalhos do professor da UFBA, Elias Machado (2003), e da professora da Pontifícia Universidade Católica de São Paulo (PUCSP), Pollyana Ferrari (2010b).

O comportamento de consumo digital e da adoção de constantes atualizações tem como base o livro Diffusion Of Innovations, do professor da Universidade do Novo México, Everett Rogers (2003), que expõe pressupostos referentes às inovações no cenário permeado pelas constantes atualizações de equipamentos e aplicações, um tema recorrente no quesito acesso ao ciberespaço.

As mídias digitais têm um aspecto em comum com os meios eletrônicos: o registro que visa retratar com semelhança a realidade (escrita e audiovisual). Em suma: a captação de voz, imagens e textos por meio das interfaces de microfones, câmeras e teclados de escrita. Enquanto se tangencia o mesmo objetivo, há uma diferenciação que não difere ou afasta a digitalização, pois a mídia rotulada como analógica traz apenas uma única característica básica: suportes em processos de codificação e decodificação (HALL, 2003, p.359-360):

\footnotetext{
Você tem de saber, analiticamente, por que o consumo e a produção são diferentes, a fim de falar sobre como eles se articulam. Você tem de reconhecer a diferença em cada ponto. Se gasto algum tempo falando sobre os momentos da codificação e da decodificação, isso não me impede de ver as relações entre eles. Chamo de codificação e decodificação duas práticas diferentes, mas relacionadas, que conectam o que pode ser analiticamente identificado como dois momentos isolados.
}

A fim de não desembocar na generalidade de vantagens e desvantagens no embate digital versus analógico, a abordagem sobre mídia digital se debruça, especificamente, sobre o acesso ao ciberespaço (internet e redes de dados) e sobre a forma como canais de interação entre usuários (sites, blogs, chats, e-mail e redes sociais) se processam no âmbito da interação intersubjetiva. No caso deste trabalho, interessam as redes de comunicação entre produtores de conteúdo e jornalistas no ciberespaço.

Em decorrência da percepção de uma dicotomia envolvida em uma perspectiva digital, além dos números, existe uma razão organizacional que remonta a estágios das revoluções industriais a ponto de ressaltar demandas em dinâmicas de consumo, conforme a explicação de Ferrari (2016, p.21): 
Outras mudanças organizacionais, tais como sistema de entrega just-intime (que reduziram o processo industrial, em meio à crise do Fordismo) vão mostrar que, nesta década, iniciou-se a ruptura com o analógico, com o mundo concreto do século XX, um período do qual não nos orgulhamos; com suas duas guerras mundiais, ameaças nucleares impostas pela Guerra Fria; as terríveis experiências de Hiroshima e Nagasaki, golpes de estado por parte de governos militares e um começo de globalização que veríamos na TV a partir da década de 1990; quando o mundo assistiu aos ataques norte-americanos no Golfo como se fossem telas de videogames de ação.

Paralelamente a isso, o jornalismo contemporâneo pressupõe o convívio com uma rotina de rápida atualização da formação profissional do jornalista que atua na área de esportes diante das possibilidades da tecnologia e da mídia convergente (JENKINS, 2009), com ressalvas ao modo de mediar e ser mediado pelos dispositivos tecnológicos de acesso ao ciberespaço. Afinal, os processos de comunicação tipificados com o uso de ferramentas cibernéticas impactaram também a prática da produção de notícia.

O potencial do uso de ferramentas web no jornalismo influi diretamente na atuação do site do COB. Além disso, o espaço conta com conteúdo informativo do IOC, que dispõe de uma produção especializada por meio do OBS (Olympic Broadcasting System). Este canal detém a exclusividade das notícias que são negociadas sob contratos de direitos de transmissão, conforme a descrição que consta no sítio dessa empresa ${ }^{19}$ :

O Olympic Broadcasting Services (OBS) foi criado pelo Comitê Olímpico Internacional (IOC) em 2001 a fim de atuar na organização do Host Broadcaster em todos os Jogos Olímpicos, Olimpíadas de Inverno e Jogos Olímpicos da Juventude.

O Host Broadcaster é responsável pela entrega de imagens e sons dos Jogos Olímpicos a bilhões de espectadores por todo o mundo. Ele produz e transmite por rádio e televisão, ao vivo, os acontecimentos de forma imparcial sobre todos os esportes de todos os lugares. Este abastecimento é chamado de Sinal Internacional ou Alimentador Mundial.

Neste papel, o OBS é responsável pela realização de uma abordagem consistente das transmissões olímpicas ao mesmo tempo em que otimiza os recursos para melhorar continuamente a eficiência da operação do Host Broadcaster.

O OBS então atua para assegurar que todas as obrigações contratuais do IOC estejam presentes nos Direitos de Transmissão das Emissoras Licenciadas (RHBs) ocorram de ponta a ponta com a produção televisiva dos Jogos Olímpicos.

\footnotetext{
${ }^{19}$ Disponível em: https://www.obs.tv. Acesso em: 28 ago. 2016.
} 
A discussão sobre atuação institucional do IOC dispõe de mecanismos de padronização da notícia olímpica dos canais credenciados. Sendo assim, tornou-se uma opção desempenhar o papel de usuário passivo, que não se expressa, ao contrário do que observa o professor e pesquisador da Universidade de Sorocaba (Uniso) e da Faculdade de Tecnologia de São Paulo (Fatec), Wilton Garcia (2011, p.55) ao falar do usuário-interator:

Hoje, o sujeito passa a ser considerado como usuário-interator, sobretudo na internet, cuja situação parcela, compartilha, coopera e conecta. Essa experimentação interpela, interfere e se confirma por meio de um diagrama transversal que utiliza um amplo descrever de características complementares.

Com base nas características postas por Garcia (2011), pode-se afirmar que esse usuário-interator não fica restrito a papéis formais, como público/audiência e produtor/gerador de conteúdo. Essa possibilidade de produzir conteúdo ao mesmo tempo em que acessa sites e redes sociais reflete um pouco também da tortuosidade no caminho a ser percorrido no estudo das interfaces esportivas.

De modo geral, o trabalho dos jornalistas com o auxílio de ferramentas provenientes dos computadores também sofreu impacto dos aprimoramentos referentes a recursos que normalmente demarcam mudanças sutis na forma como a comunicação cibernética se realiza na difusão de informações. Nesse caso, especificamente, a World Wide Web ou, em tradução livre: a ampla teia mundial.

Inserido nesta teia, o jornalismo olímpico do site do $\mathrm{COB}$ considera as modalidades olímpicas com pouca cobertura na mídia que, neste espaço, passam a contar com notícias a ponto de fomentar sua visibilidade na imprensa tradicional em sítios de confederações e em veículos da mídia independente. Dessa maneira, um usuário-interator (GARCIA, 2011) também encontra na internet um repertório informativo que contribui para auxiliar no desenvolvimento do esporte e de atividades físicas e motoras.

Ferrari (2010b, p.93) assinala características tanto do espaço digital como do trabalho de jornalistas:

A distinção fundamental que está em jogo é a de que a comunicação tem a ver com conteúdos e com a circulação [...] Nestes termos, a informação não diz respeito à transmissão de conteúdos. Destacamos a importância de olharmos para o futuro do jornalismo - que passa por uma transformação conceitual e organizacional, assumindo uma identidade $100 \%$ informativa. Os profissionais não escrevem mais para o jornal. São bits que trafegam informação e não mais átomos. E nesse contexto, nos perguntamos quem 
é esse ciberleitor?

O ciberespaço passa a ter um entendimento mais simplificado, de acordo com uma teoria da adoção rápida a serviço/equipamento. Formulada em 1962 pelo sociólogo norteamericano Everett Rogers (2003), o estudo relaciona a maneira como novidades difundidas têm adesão ou rejeição. No âmbito do consumo, se forma uma perspectiva de mudança social, como, por exemplo, a energia elétrica e as possíveis causas, como benefícios e problemas que esta traria.

A produção de notícias em sites, principalmente com a utilização de serviços de publicação online, inspirou o professor da Universidade de Beira Interior, em Portugal, João Canavilhas (2006, p.03), a considerar as características da agilidade e da disponibilização de informações por meio digital:

Embora o número de utilizadores em todo o mundo tenha atingido uma dimensão interessante, o ritmo de crescimento da banda larga condiciona o tipo de conteúdo oferecido pelo jornalismo que se faz na web. Naturalmente, as publicações apostaram nas notícias baseadas em texto escrito já que o download das páginas é relativamente rápido mesmo para acessos de baixa velocidade. É por isso que o texto continua a ser o elemento mais usado no jornalismo que se faz na web, mas este não é o único motivo para que tal se verifique.

Para estabelecer uma aproximação entre consumo de internet, jornalismo, interação dos usuários e acesso às notícias pela $w e b$ - a partir de um perfil de consumo digital - há ainda outro pilar da utilização do ciberespaço além da difusão de informações. Como esclarece Machado (2003, p.88):

A expansão do ciberespaço como uma esfera pública depende da forma como as organizações jornalísticas incorporam os usuários em seus sistemas de produção. Até agora, os usuários são vistos como consumidores de notícias. Na redação como espaço para a administração das informações, os usuários devem ser estimulados a participar como colaboradores na produção de conteúdos.

A utilização de ferramentas cibernéticas para a produção de notícias não se apresenta como uma novidade no Brasil, porque os serviços de provimento e acesso à internet existem há aproximadamente vinte anos. No final de anos 1990, parte dos principais recursos multimídia da World Wide Web estava em fase de testes. No entanto, ao longo da década de 
2000, o aparecimento das redes sociais proporcionou que os usuários publicassem seus conteúdos audiovisuais em uma dinâmica de produção e consumo concomitantes.

Em meio a esses processos relacionados às mídias digitais, o professor da Universidade de Navarra, Ramón Salaverría (2017, p.04), destaca os seguintes modelos:

\begin{abstract}
A partir de um critério de classificação baseado no grau de evolução digital. Sua tipologia incluía as seguintes categorias: (1) o "modelo de facsímile", que consiste em reproduzir fielmente a versão impressa de um meio na internet, através, por exemplo, de um documento em PDF; (2) o "modelo adaptado", baseado em conteúdos igualmente impressos, mas ajustado às possibilidades comunicativas da rede; (3) o "modelo digital", em que os conteúdos já foram expressamente preparados para a internet, mas com critérios editoriais próprios de mídias anteriores; e, finalmente, (4) o "modelo multimídia", onde tanto os conteúdos como as linguagens usadas para sua representação são inteiramente digitais. Propostas tipológicas semelhantes, que enquadram a mídia em um continuum. (Tradução e itálicos nossos) $^{20}$
\end{abstract}

Os dispositivos digitais com acesso à web dispõem de interfaces em formato hipermídia, cuja principal característica de comunicação depende da vontade do usuário. Para exemplificar, um navegador de internet, ao ser acionado, abre uma página (predefinida ou configurada pelo usuário) e, mesmo que esse local conte com atualizações, os canais não se alteram sem que essa pessoa entre com o endereço de outros sites e hiperlinks relacionados. Além disso, textos em listas automáticas ficam à espera da reação do usuário.

As formas de interação aproximam o comportamento do prosumer - produtor e consumidor (TOFFLER, 1980) - do usuário-interator (GARCIA, 2011) nos ambientes digitais. Além dos computadores, os dispositivos móveis e outros híbridos, como smarTVs e centrais multimídia em automóveis, utilizam as interfaces de comunicação com os usuários que interagem com os dispositivos.

De acordo com o teórico e escritor norte-americano Steven Johnson (2001, p.121), um sistema de buscas assim funciona:

Decidimos que critério geral queremos usar: documentos que abranjam o mesmo tópico, mas num nível mais alto de complexidade, ou uma

\footnotetext{
${ }^{20}$ No original, em espanhol: "A partir de un criterio clasificador basado en el grado de evolución digital. Su tipología incluía las categorías siguientes: (1) el "modelo facsimilar", consistente en reproducir em internet de modo fiel la versión impresa de un medio, a través, por ejemplo, de un documento PDF; (2) el "modelo adaptado", basado en contenidos igualmente impresos, pero acomodados a las posibilidades comunicativas de la red; (3) el "modelo digital", en el que los contenidos ya han sido expresamente elaborados para Internet, pero con criterios editoriales propios de medios anteriores; y, finalmente, (4) el "modelo multimedia", donde tanto los contenidos como los lenguajes empleados para su representación son enteramente digitales. Propuestas tipológicas similares, que encuadran los medios en un continuum”. (Itálicos nossos).
} 
varredura geral de quaisquer documentos vagamente relacionados com o documento de amostra, ou um ensaio escrito num estilo semelhante. $\mathrm{O}$ software configura então seus algoritmos de comparação de padrões para se ajustar aos critérios que escolhemos, examina todas as palavras à disposição e monta um perfil do texto de referência e de suas filiações com o restante do banco de dados.

O usuário-interator (GARCIA, 2011) do ciberespaço grava e reproduz conteúdo multimídia com a mesma facilidade com que as fitas-cassete proporcionavam a postura prosumer (TOFFLER, 1980). No entanto, hoje há facilidade na circulação desse material caseiro, cuja diferença se nota na ausência do desgaste do arquivo digital. Esses materiais apenas apresentam deterioração por meio da corrupção a partir do download e/ou cópia malsucedida, em que as cadeias numéricas (dígitos) ficam distorcidas e, em vez da perda de qualidade, torna-se impossível executar ou visualizar esse arquivo.

\subsection{Comunicação digital: dinâmicas e espaços}

A possibilidade da realização da comunicação em duas vias nos meios cibernéticos tornou-se um tema recorrente nas pesquisas de Lévy (1999, p.57), que considera a metáfora da interação atômica, em nível molecular, tal como sujeitos se comunicam entre si na sociedade contemporânea:

Do mesmo modo que um cérebro pensa na ausência de centro ou de um cérebro acima dele para dirigi-lo, um grupo molecular não tem necessidade de uma mediação transcendente para se unir. A evolução técnica tornou a transcendência obsoleta. [...] Assim como as mensagens do ciberespaço interagem e invocam-se de um extremo a outro de um plano desterritorializado, os membros dos coletivos moleculares se comunicam transversalmente, reciprocamente, fora de categorias, sem passar pela via hierárquica, dobrando e redobrando, cosendo e recosendo, complicando a seu bel prazer o grande tecido metafórico das cidades calmas. (Itálicos do autor).

A partir das diversas formas interação entre usuário-máquina e usuário-usuário, ressaltam-se as peculiaridades intrínsecas do digital como meio de interface, desde os hiperlinks para a vinculação de lugares em cascata até a formatação dos sites.

A concepção de emulação (HOEVEN; LOHMAN; VERDEGEM, 2017), no âmbito da informática, entende a utilização desses espaços como meio de preservação da memória de um passado digital incompatível com os dispositivos utilizados na atualidade. Para os pesquisadores europeus Jeffrey van der Hoeven, Bram Lohman e Remco Verdegem (2017, 
p.124):

[...] a emulação não se concentra no objeto digital, mas no ambiente hard [ware]- e software em que o objeto é entregue. Ela visa (re)criar o ambiente no qual o objeto digital foi originalmente criado. (Tradução nossa $)^{21}$

Dessa forma, a emulação de outras mídias em aplicação na web torna-se exemplificada na exibição de uma página que mostra em tela cheia as imagens de câmeras de monitoramento em computadores ou outros dispositivos em que se percebe a recriação da experiência de se assistir a um circuito fechado de televisão que depende apenas dos equipamentos utilizados.

Os espaços de emulação na web não se restringem à forma como um software interpretador proporciona a execução em dispositivos digitais utilizados na década de 2010. Como exemplo, destaca-se como os sites temáticos para áudio, vídeo e gravuras coexistem, de modo que a emulação dessas mídias e processos de formatação de jornal, revista, rádio e televisão dividem as áreas dos sítios em meio a textos e hiperlinks.

Outra característica presente na dinâmica da comunicação digital pela web tangencia a remediação, termo estudado pelos professores norte-americanos David Bolter e Jay Grusin (2000) para descrever a representação de uma mídia em outra. Para ilustrar esse conceito, basta pensar nas páginas da web de emissoras de rádio, com o player em destaque para a programação ao vivo, com trechos da programação.

A partir da confluência de conteúdos produzidos em rede, o conceito de convergência (JENKINS, 2009) impacta a vida em sociedade. Um desses impactos ocorre a partir do modo como o próprio Jenkins (2009) aborda a intervenção de pessoas que se apropriam de produtos culturais, com ênfase na literatura e, por conseguinte, as transliteraturas, como Star Wars e Harry Potter (JENKINS, 2009, p.275): por meio de contos paralelos. Na convergência conceituada por Jenkins (2009), o modo como a história recontada pelos fãs impacta sequências alternativas e outros episódios incorre no estabelecimento de um novo universo que coexiste em termos metafísicos com o original.

Em relação às convergências, Salaverría (MONTEIRO, 2017), em entrevista ao jornal $A$ Voz de Galiza, ressalta a importância da seletividade em relação ao fato jornalístico:

\footnotetext{
${ }^{21}$ No original, em inglês: "[...] emulation does not focus on the digital object, but on the hard- and software environment in which the object is rendered. It aims at (re)creating the environment in which the digital object was originally created".
} 
O jornalismo sempre lidou contra o relógio. As novas tecnologias nos permitem fazer as coisas instantaneamente e os protocolos de prudência profissional para não comprometer a credibilidade do seu veículo são muito mais exigentes. Mas também temos melhores ferramentas para certificar a informação [...] Os jornalistas devem saber adaptar-se com enorme flexibilidade às tecnologias, mas ser inflexíveis em relação aos valores profissionais. Os meios que estão conseguindo ter sucesso no cenário digital são aqueles que respeitam os eixos de seus valores clássicos, mas buscam mudanças tecnológicas e inovar. (Tradução e itálicos nossos $)^{22}$

Essa mesma necessidade emerge a partir das observações do professor da Universidade Santiago de Compostela, Xosé López García (2008, p.08), ao considerar a convergência e a necessidade de se averiguar as informações:

O desafio colocado pelos cibermeios não se refere apenas à revisão do que entendemos local e por meio local, mas também à organização do conteúdo de proximidade nos cibermeios e na mídia em geral. Como sabemos, os temas jornalísticos são algo mais do que a soma de uma série de notícias ou opiniões ordenadas de acordo com as diferentes negociações entre os diferentes atores que tornaram isso possível. Produzir uma pauta de um jornal que respeite a complexidade dos fatos e aprofunde em sua interpretação implica uma reflexão prévia sobre a sociedade em que é produzido e desenvolvido e um propósito de oferecer significados para entendê-lo ou, pelo menos, saber como se desenvolvem. (Tradução nossa $)^{23}$

Desse modo, se a dinâmica ficcional se aplica especificamente à literatura, o jornalismo exige que seu profissional seja "flexível na tecnologia, mas inflexível nos seus valores" (SALAVERRÍA, 2017), a partir da concepção da história recontada por meio de um recorte da realidade e do registro de relatos obtidos com as fontes que testemunharam os fatos relevantes para a notícia.

\footnotetext{
${ }^{22}$ No original, em galego: "O xornalismo sempre lidou contra o reloxo. As novas tecnoloxías permítennos facer as cousas de xeito instantáneo e os protocolos de prudencia profesional para non comprometer a credibilidade do teu medio son moito máis esixentes. Pero tamén dispomos de ferramentas mellores para certificar a información [...] Os xornalistas deben saber adaptarse con enorme flexibilidade ás tecnoloxías pero ser inflexibles co respecto aos valores profesionais. Os medios que están a conseguir triunfar no escenario dixital son os que respectan a machada os seus valores clásicos pero buscan o cambio tecnolóxico e inovar". (Itálicos nossos).

${ }^{23}$ No original, em espanhol: "El desafío planteado por los cibermedios no se refiere sólo a la revisión de lo que entendemos por local y por medio local, sino también a la organización de contenidos de proximidad en los cibermedios y en los medios de comunicación en general. Como sabemos, el temario periodístico es algo más que la suma de una serie de noticias u opiniones ordenadas de acuerdo a las distintas negociaciones entre los diferentes actores que lo han hecho posible. Producir una pauta de un diario que respete la complejidad de los hechos y profundice en su interpretación implica una reflexión previa sobre la sociedad en que la se produce y desarrolla y un proposito de ofrecer significados para comprenderla o, al menos, saber desenvolverse en ella".
} 
Ferrari (2010b, p.51-53) complementa a necessidade de adaptação às tecnologias, exemplificando padrões de produção e consumo na web:

Além do texto, é possível utilizar áudio, gráficos, vídeo, links, etc. E até uma combinação de todos esses recursos. [...] Use e abuse de verbos fortes que o ajudarão a escrever um texto vivo, arejado e alegre. A web não é sisuda, ela tem humor. O público online é mais receptivo para estilos não convencionais, já que o leitor não tem tanto compromisso ao navegar, ele "zapeia" pelos canais, ficando alguns poucos minutos na notícia que lhe interessa.

\subsection{Esportes e Jogos Olímpicos: site do COB}

A ocorrência de torneios mundiais no Brasil proporcionou uma aproximação da pauta esportiva e olímpica de temas que normalmente não possuem abordagens conjuntas e recorrentes como gastos excessivos na infraestrutura, já que se encontram associados a outras editorias, como economia e internacional. Devido à realização das Olimpíadas no Rio de Janeiro, as notícias que envolveram esse evento ganharam destaque nas pautas esportivas, conforme a menção de Helal (2015), com "o viés cultural da pauta esportiva" no âmbito nacional, estendendo-se para aspectos locais. Sendo assim, como ponto de apoio para a pesquisa, foi fundamental fazer uma análise preliminar do site do Comitê Olímpico do Brasil (COB), entre abril e maio de 2015.

O sítio do COB possui uma apresentação direta a partir do acesso em navegadores que adotam o padrão de tabulação de textos e elementos em espaços da web, nomeadamente o Cascated Sheet Style 3, o CSS3, a terceira revisão da apresentação em cascata em utilização nas principais páginas (e mais acessadas), que consiste na diretriz do layout de apresentação gráfica, com a utilização de fontes remotas.

Além das possibilidades do CSS3, a principal vantagem consiste na diminuição do tempo de carregamento (ou download do conteúdo) da página. O site adota um formato recorrente em páginas que possuem acessos regulares de usuários: um banner (ou faixa gráfica) central, que ocupa o topo da tela com a identificação do COB, com a bandeira nacional brasileira e o símbolo olímpico logo abaixo. As cores utilizadas remetem à paleta de cores da bandeira, com branco para o fundo de página e corpo de texto; azul ou verde para destaques e amarelo para realces gráficos de alguns elementos.

Entretanto, o protocolo de exibição CSS3 possui desvantagens, sobretudo, no acesso ao site a partir de dispositivos sem suporte, que não podem ser atualizados. Dessa vez, o principal motivo que se apresenta como vantagem também acaba por inviabilizar a exibição 
dos elementos e o acesso fácil se traduz em dificuldade. A imagem abaixo reproduz a página do COB a partir da versão obsoleta (10.1) do navegador Opera:

Figura 2 - Página do COB a partir de navegador desatualizado

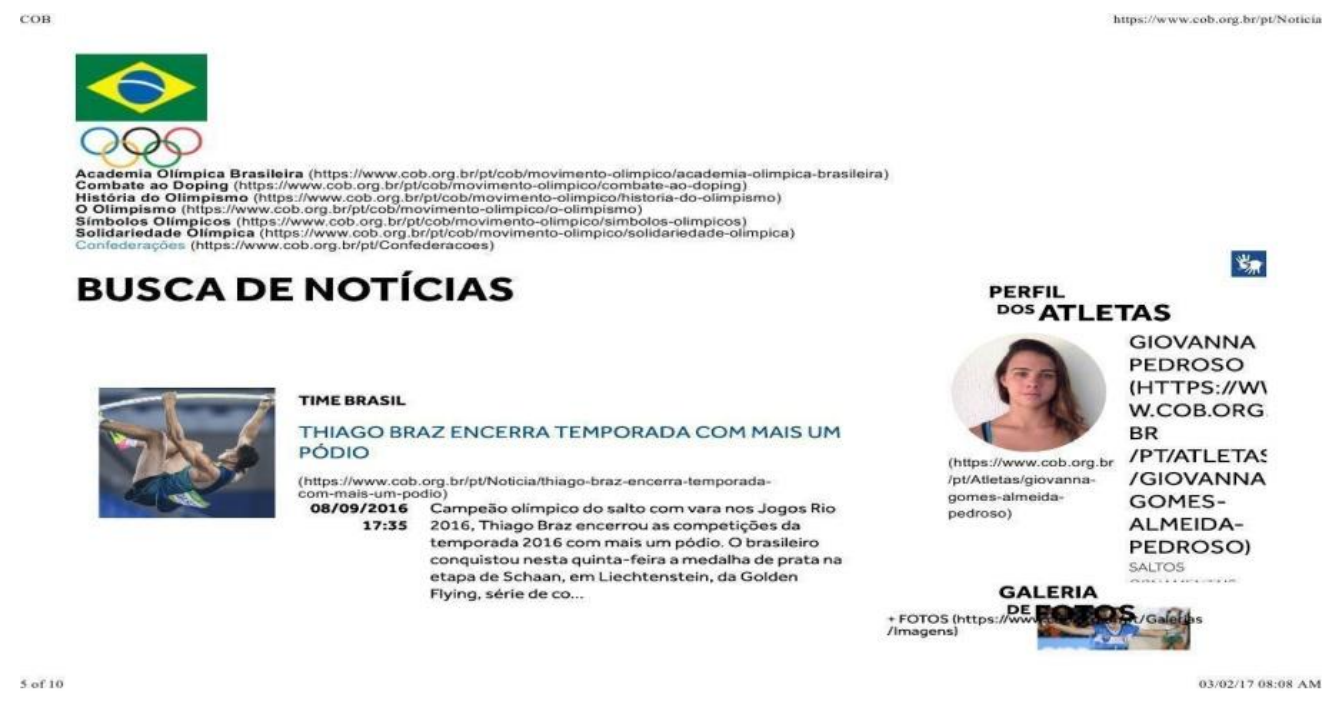

Fonte: $<$ http://www.cob.org.br/pt/noticias $>$. Acesso em: 18 nov. 2016

Em meio ao surgimento de inúmeros sites das confederações esportivas no Brasil, destaca-se o conteúdo publicado pelo COB, que não trata apenas das informações e eventos da entidade. Durante as 'janelas' bissextas de quatro anos, a pauta olímpica ganha destaque e os campeonatos de base, como os Jogos Escolares da Juventude, aparecem sublinhando como atletas passam a conviver com a possibilidade de profissionalização e posterior atuação em Jogos Olímpicos.

Como meio de comunicação oficial, as informações do COB pautam-se pelos valores em destaque na seção Sobre o $C O B$, como "missão, valores, paixão pelo esporte e trabalho em equipe", além do reforço dos motes olímpicos: "amizade, excelência e respeito"24 (imagem a seguir):

\footnotetext{
${ }^{24}$ Disponível em: <http://www.cob.org.br/pt/cob/comite-olimpico-do-brasil/sobre-o-cob $>$. Acesso em: 12 dez. 2016.
} 


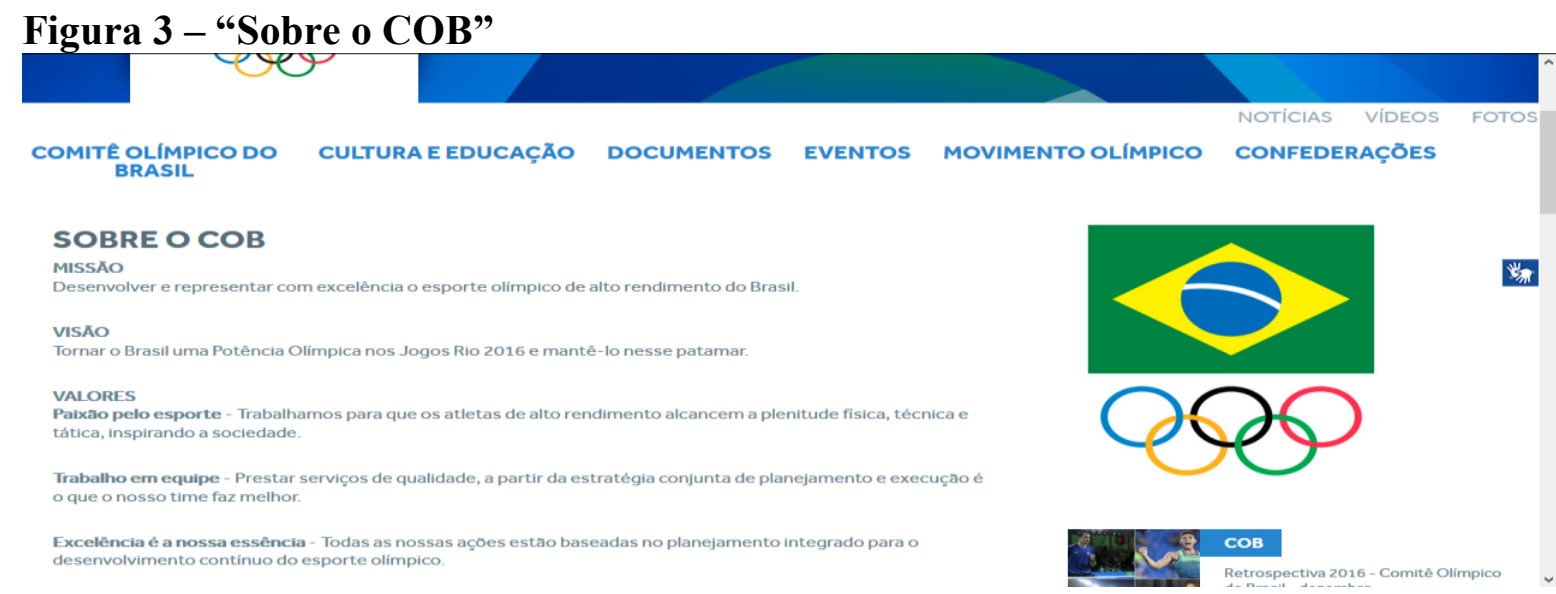

Fonte: <http://www.cob.org.br/pt/cob/comite-olimpico-do-brasil/sobre-o-cob>. Acesso em: 12 dez. 2016

A cobertura do Time Brasil, ilustrada principalmente nas notícias dos esportes publicadas pela página online do $\mathrm{COB}$, tem como enfoque os atletas confederados. A separação temática compreende três eixos: Jogos Olímpicos, Atletas e Jogos Escolares da Juventude.

Em vez de serem elencadas por rótulos digitais (tags ou labels), a apresentação das notícias de acordo com cada editoria propõe uma organização que facilite a busca e que não provoque confusão ao se misturar assuntos dos Jogos de Verão com os atletas brasileiros que participam de partidas em Jogos Escolares da Juventude. Embora esses temas fizessem parte do contexto olímpico, havia dois níveis diferentes de atletas envolvidos: nas escolas (categoria correspondente ao amadorismo) e nas competições internacionais (realizadas a cada quatro anos: esportistas considerados de alto rendimento).

No site do COB, a disponibilização de informações sobre os esportes olímpicos para brasileiros interessados no assunto destaca características identitárias, com reforço de valores e cores nacionais, como observa o filósofo Hans Ulrich Gumbrecht (2015, p.84):

\footnotetext{
Para cada espectador individual, uma bela jogada do seu time produz um instante de felicidade. Respiramos fundo e, por um momento, percebemos que a façanha e a confiança dos jogadores se tornaram contagiosas e parecem nos arrebatar. Ao menos é o que a maioria dos espectadores espera que lhes aconteça, mais precisamente - e inconscientemente - todos aqueles que interiorizaram as regras e o ritmo do jogo, e que não têm uma abordagem profissional na análise do que acontece em campo (como os treinadores e os jornalistas).
}

Ao discutir a ênfase no espectador, Gumbrecht (2015) também aponta a possibilidade de ampliação e operação de interfaces jornalísticas com outras editorias em âmbito nacional e, possivelmente, internacional. As notícias dos Jogos Olímpicos do Rio 
2016 têm, ao mesmo tempo, um envolvimento com modalidades diferentes. Nesse caso, ainda que as práticas permaneçam desconhecidas - sem recorrência em noticiários e com pouca visibilidade na mídia brasileira - o cenário compõe-se, preponderantemente, pelas seguintes modalidades: futebol, basquete, vôlei e natação; estação de campeonatos e ‘janelas' olímpicas; valores esportivos (como moral e ética das modalidades).

Além disso, a ficha de atletas confederados apresenta a biografia daqueles que passam a protagonizar sagas de luta e superação (TUBINO, 2007) a partir da conquista de uma medalha. Para exemplificar:

1. Elegância e brasilidade marcam uniformes de desfile no Pan de Toronto 2015 (interface com moda) $)^{25}$

2. Governador Pezão firma termo de compromisso de cessão de terreno ao COB (política) ${ }^{26}$

3. Comitê Olímpico do Brasil realizará reunião com rede hoteleira de Fortaleza (turismo) $)^{27}$

A seleção dessas reportagens adotou o critério de buscar as notícias publicadas no site do $\mathrm{COB}$ que se diferenciassem do arquétipo tradicional da cobertura esportiva: aquelas que apresentavam resultados e biografias de atletas. Essa tentativa teve o objetivo de compreender, em um primeiro momento, como a pauta olímpica se desenvolvia a partir do COB, responsável pela organização dos Jogos do Rio de Janeiro de 2016. Por esse motivo, o Comitê divulga a prática desportiva (RUBIO, 2015) sem enfatizar a tônica de "vencedores e derrotados".

Como exemplo de diversificação, decidiu-se incluir a seguinte matéria, que ganhou espaço na divulgação de resultados de alto rendimento durante os Jogos Pan-Americanos de Toronto:

- Esgrimista brasileiro recebe prêmio internacional por fair play: Guilherme Murray

\footnotetext{
25 Disponível em: <http://www.cob.org.br/pt/Noticia/elegancia-brasilidade-marcam-uniformes-desfile-detoronto-2015>. Acesso em: 15 mai. 2015.

26 Disponível em: <http://www.cob.org.br/pt/Noticia/governador-pezao-firma-termo-de-compromisso-decessao-de-terreno-ao-cob>. Acesso em: 31 abr. 2015.

${ }^{27}$ Disponível em: <http://www.cob.org.br/pt/Noticia/comite-olimpico-do-brasil-realizara-reuniao-com-redehoteleira-de-fortaleza>. Acesso em: 31 abr. 2015.
} 
alertou árbitro sobre erro em pontuação a seu favor ${ }^{28}$

Dessa forma, houve uma aproximação em torno das outras interfaces com o esporte olímpico - como turismo, moda, política e valores éticos-morais - para posteriormente se verificar a maneira como a editoria esportiva atuava em conjunto com outras. Como exemplo, há uma pauta recorrente no jornalismo esportivo brasileiro, que faz interface com a seção policial, sobre torcidas de equipes de futebol que cometem atos de violência.

Ao sediar as Olimpíadas, o Brasil também ofereceu à esfera do jornalismo esportivo uma imediata interface com o turismo em uma dinâmica diferente: a do planejamento urbano, com projetos de intervenção visual e infraestrutural, e do tratamento publicitário com ênfase em apresentações corporativas. Na fase de preparativos dos Jogos, os canais de promoção do evento surgiram na rede não apenas para impressionar e convencer o público estrangeiro sobre a capacidade e os benefícios da realização do evento no Rio. Eles também apresentaram projetos de planejamento urbanístico, cuja ousadia tangenciava temas de melhorias tratados como utópicos e irrealizáveis em campanhas políticas de candidatos à prefeitura carioca ou ao governo estadual do Rio de Janeiro.

Entre as notícias específicas do COB durante a preparação dos Jogos, as principais envolveram a entrada em vigor da Lei Agnelo Piva ${ }^{29}$, que possibilitava parcerias públicoprivadas entre entidades governamentais e empresas, e as solenidades de inauguração das obras de melhoramento urbano, como as estações de VLT (veículo leve sobre trilhos), entre a Zona Oeste e a região do Porto Maravilha, no Rio de Janeiro. Enquanto o site do COB se dedicou à divulgação de edificações para os Jogos Olímpicos de 2016, a comissão organizadora do evento, intitulada Rio Cidade Olímpica, ficou encarregada de conteúdos promocionais sobre o Rio de Janeiro e de projetos no entorno da cidade que tiveram como enfoque a revitalização de uma área abandonada.

Com ênfase na linguagem promocional de audiovisuais, o canal de vídeos dessa comissão no YouTube deixou pistas sobre isso, como as compilações audiovisuais (playlists) separadas por tópicos como meio ambiente, transportes e infraestrutura e instalações olímpicas (imagem a seguir).

\footnotetext{
${ }^{28}$ Disponível em: <http://www.cob.org.br/pt/Noticia/esgrimista-brasileiro-recebe-premio-internacional-porfair-play>. Acesso em: 31 abr. 2015.

${ }^{29}$ Lei 10.264, que vigorou entre 2001 a 2016. Destinou recursos públicos federais a obras de infraestrutura no Rio de Janeiro. Disponível em: 〈http://www.brasil2016.gov.br/pt-br/incentivo-ao-esporte/lei-agnelo-piva〉. Acesso em: 30 mai. 2017.
} 
Figura 4 - Vídeo institucional "Cidade Olímpica"

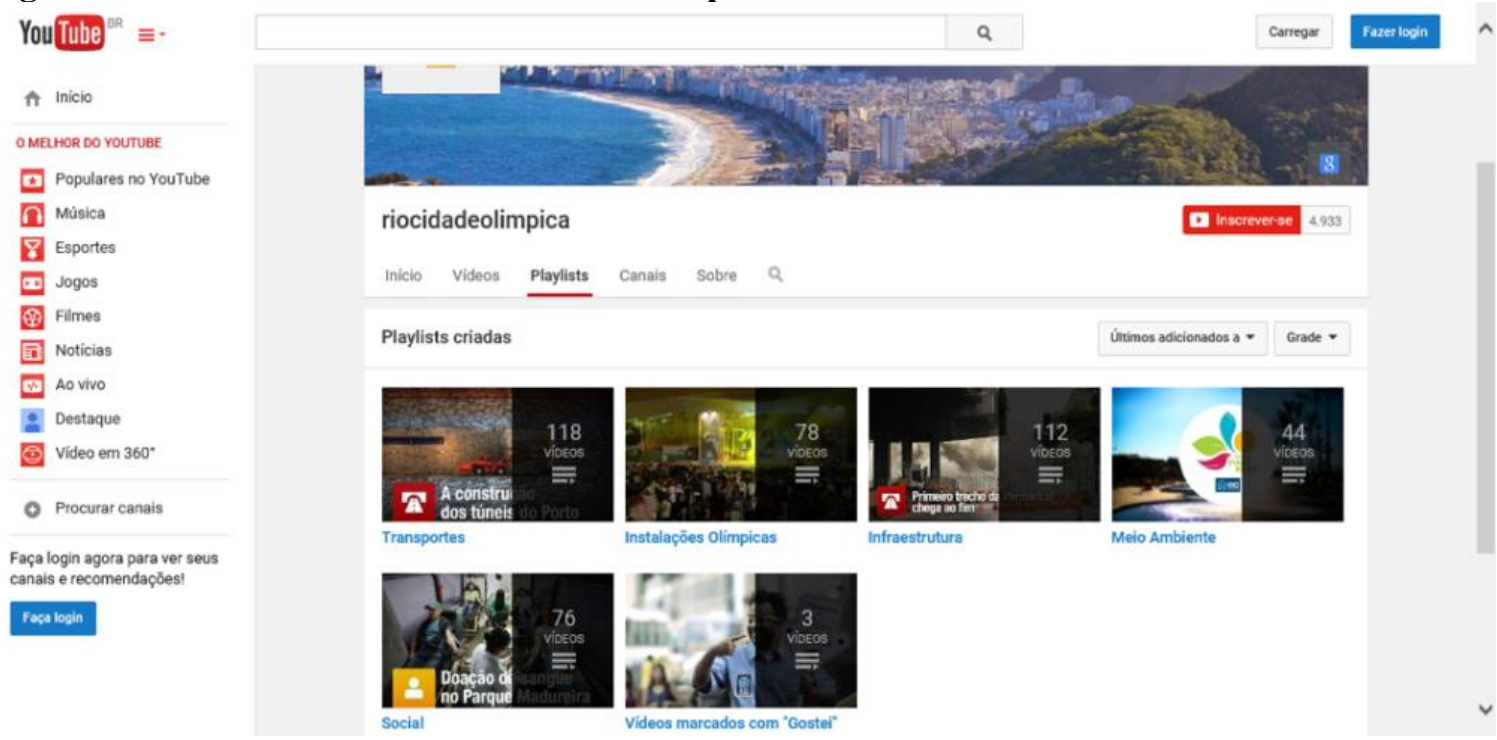

Fonte: $<$ http://www.youtube.com/watch?v=-Ak6MdGfL8Q>. Acesso em: 21 jun. 2015.

Por sua vez, a seção Social (destinada ao compartilhamento em redes) mostra aspectos interessantes, como vídeos que enfatizam, junto à opinião pública, o policiamento nos morros e sua aceitação como forma de coibir (ou resolver) as mazelas da violência urbana. Merecem destaque os vídeos intitulados 'Michael Phelps visita a Vila Olímpica do Alemão'; 'Meu bairro, minha vida'; 'Morar carioca, uma revolução social' (imagem a seguir).

\section{Figura 5 - "Cidade Olímpica": playlists}

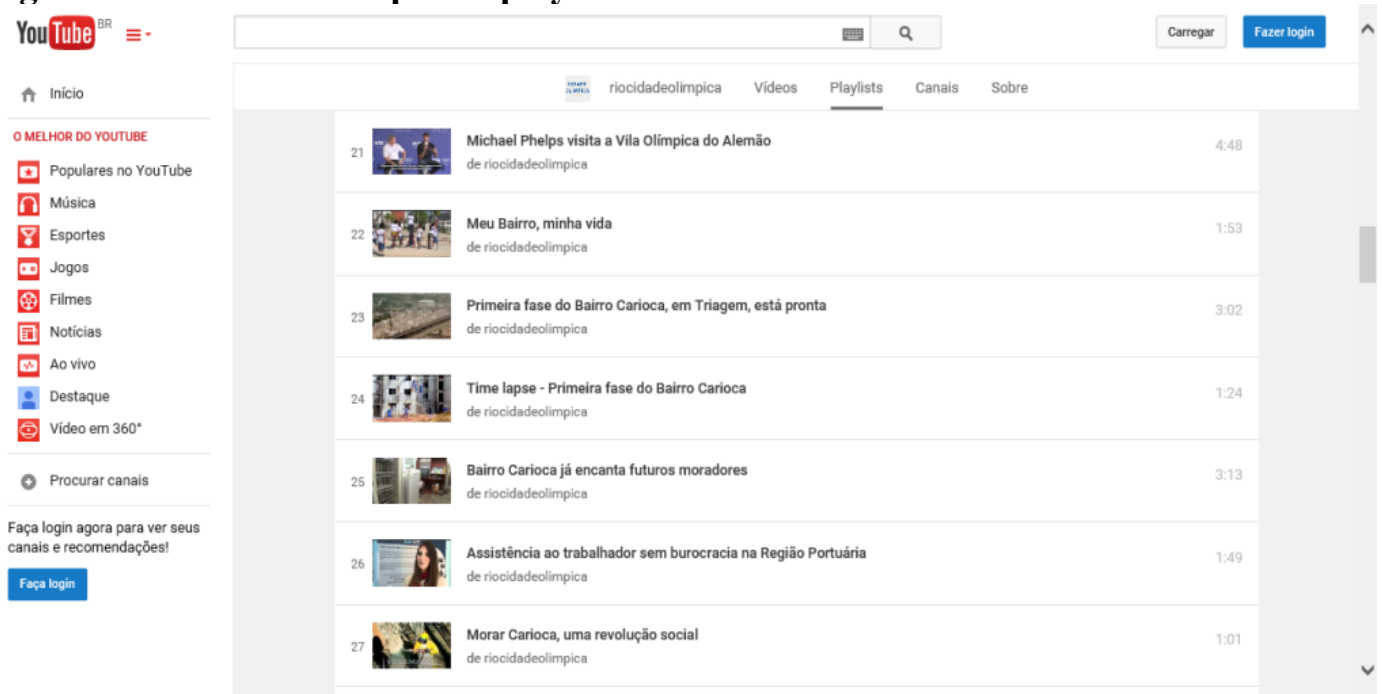

Fonte: $<$ http://www.youtube.com/watch?v=-Ak6MdGfL8Q>. Acesso em: 21 jun. 2015. 
Por fim, a seção Gostei contém vídeos como 'Trânsito no centro? Deixa que eu explico - o explicador, Prefeitura do Rio'; 'Casa, comida e simpatia no [Morro do] Cantagalo'; 'A atleta Rosângela apresenta a nova Via Expressa Transcarioca' (imagem a seguir).

\section{Figura 6 - "Cidade Olímpica": vídeos marcados com Gostei}

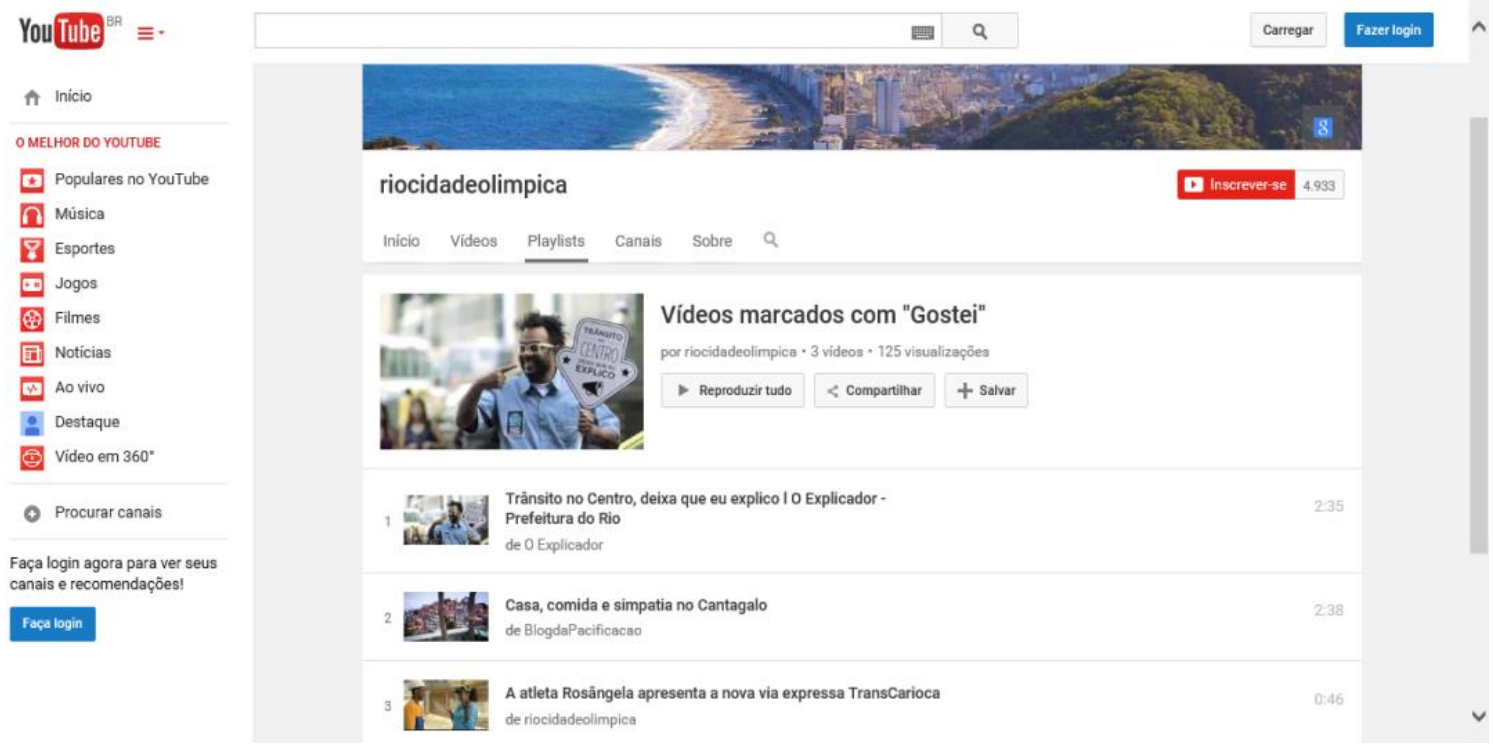

Fonte: $<$ http://www.youtube.com/user/riocidadeolimpica $>$. Acesso em: 21 jun. 2015

A utilização de fotografias como parte da produção noticiosa herdada do jornalismo impresso constitui uma das seções analisadas do site: o caráter ilustrativo da ação reportada ajuda a reforçar o propósito da fácil assimilação, com a disponibilização do conteúdo multimídia a partir do cabeçalho no topo da página do COB (imagem a seguir):

Figura 7 - "COB”: cabeçalho da página

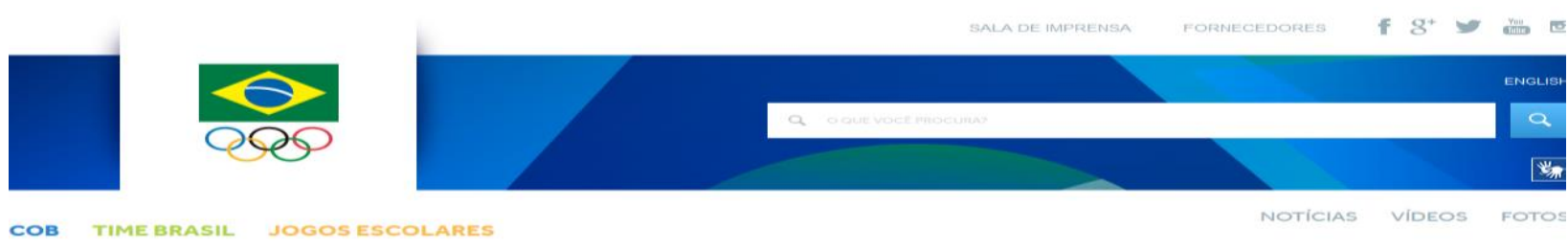

Fonte: <http://www.cob.org.br>. Acesso em: 15 dez. 2016

O canto direito abaixo do banner, com os elementos visuais, e o destaque à ferramenta de busca, logo a seguir, possuem um texto identificado com a cor cinza que traz três seções específicas de formatação midiática: notícias, vídeos e fotos. A primeira remete ao conteúdo jornalístico, associado ao novo e às reportagens; a seção seguinte traz um canal 
disponível no YouTube com entrevistas com os personagens do esporte olímpico brasileiro. Por fim, a última parte fica incumbida de aglutinar os registros visuais das partidas disputadas. O quadro a seguir caracteriza os formatos utilizados no site do COB no momento do nosso levantamento:

\section{Quadro 3 - Conteúdo multimídia do site do Comitê Olímpico do Brasil}

\begin{tabular}{|c|c|c|}
\hline NOTÍCIAS & VÍDEOS & FOTOS \\
\hline $\begin{array}{l}\text { Reúne o conteúdo textual e } \\
\text { imagético. Por exemplo, } \\
\text { recorrência ao modelo de textos } \\
\text { da mídia impressa, com estilo de } \\
\text { escrita leve da revista } \\
\text { (magazine) e fotografias que } \\
\text { ilustram a notícia. A página web } \\
\text { do COB está incorporada } \\
\text { diretamente à apresentação e ao } \\
\text { formato do hipertexto com } \\
\text { interfaces e ferramentas voltadas } \\
\text { para o compartilhamento. }\end{array}$ & $\begin{array}{l}\text { A seção apresenta material } \\
\text { audiovisual que retrata os } \\
\text { personagens da notícia: a edição } \\
\text { pautada pelo diálogo e pela fala } \\
\text { das pessoas busca o sujeito, } \\
\text { protagonizado nas figuras de } \\
\text { atletas, praticantes, treinadores e } \\
\text { especialistas. Esse ritmo de } \\
\text { edição contribui favoravelmente } \\
\text { com o entendimento de } \\
\text { expressões pessoais e subjetivas } \\
\text { de uma conversa a partir dos } \\
\text { temas da pauta e da presença da } \\
\text { linguagem oral. }\end{array}$ & $\begin{array}{l}\text { Inclui uma coleção elencada pela } \\
\text { descrição e vínculo com a } \\
\text { reportagem publicada, por meio } \\
\text { das "palavras-chave" (tag ou } \\
\text { keyword). Ao contrário de } \\
\text { compilar, as coleções revelam-se } \\
\text { um subconjunto que contém } \\
\text { partes (ou galerias). As } \\
\text { identificações podem ser } \\
\text { numéricas (quantidade e em } \\
\text { sequência não linear, com partes } \\
\text { no começo, meio e fim) ou } \\
\text { aleatórias (com crédito dos } \\
\text { autores das imagens). } \\
\end{array}$ \\
\hline
\end{tabular}

Fonte: elaboração própria

Vale a pena destacar a comunicação visual a partir de uma ferramenta de acessibilidade: o software Handtalk, programado para representar na tela a Linguagem Brasileira de Sinais (Libras) como forma de estimular a interação de internautas com deficiência auditiva. Além do texto escrito, um avatar - representação gráfica com animação virtual - surge na tela e passa a operar a fala ao realizar a mímica corporal característica de Libras em uma janela da página do COB. Infelizmente, a limitação de recursos do site inviabilizou o projeto, mesmo considerando-se a parceria que a instituição obteve para a utilização gratuita da ferramenta durante os Jogos (imagem a seguir).

\section{Figura 8 - Anúncio do conteúdo em Libras}

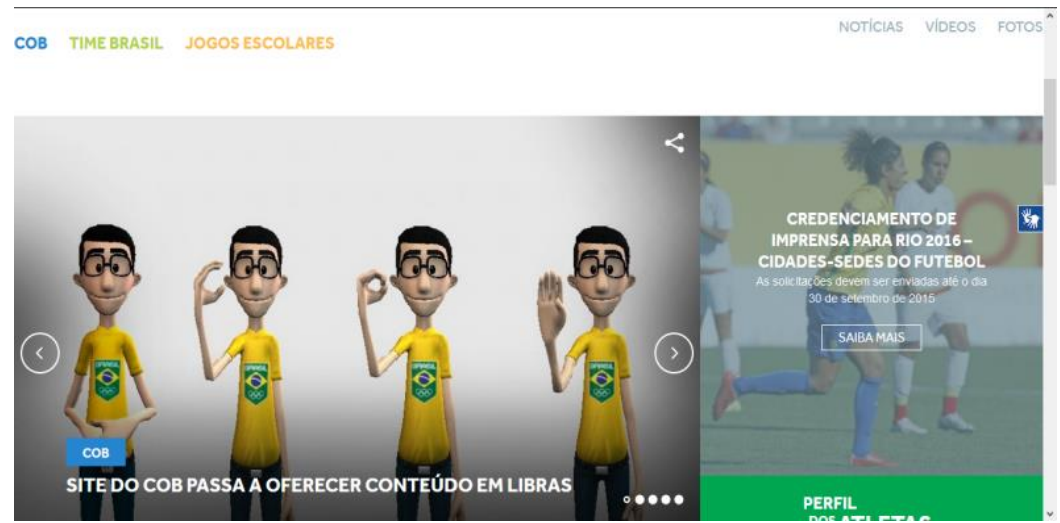

Fonte: <http://www.cob.org.br>. Acesso em 20 mai. 2015 
Professora e pesquisadora da Unesp, Suely Maciel (MACIEL et al., 2016, p.26) exemplifica a utilização de ferramentas de acessibilidade para deficientes visuais com o auxílio da linguagem radiofônica:

Quando se trata dos meios audiovisuais, as pessoas com deficiência visual enfrentam uma barreira física na compreensão do conteúdo, uma vez que a imagem é componente importante da narrativa. Com o objetivo de minimizar essa dificuldade, a audiodescrição é aplicada a essas produções, tornando-se uma parte relevante para o entendimento da obra.

A ausência de conteúdo específico em áudio pressupõe que esse recurso importante do arcabouço multimídia da internet fora prescindido juntamente com uma possível utilização da linguagem radiofônica. Para o pesquisador Armand Balsebre (2005, p.328), o som permeia os sentidos, reconstrói a imagem codificada e decodificada pela escrita verbalizada (oralidade) em recorte à realidade captada.

Em meio aos debates suscitados em fóruns virtuais em que usuários-interatores (GARCIA, 2011) abordam notícias mirabolantes veiculadas em redes sociais, a utilização de textos rápidos com depoimentos unilaterais tem chamado a atenção. Como consequência da existência de pseudoinformações proliferadas (BIAGI, 2011) nas redes sociais, a desinformação se postula como espetáculo em assuntos em que a polêmica supera o interesse público.

O jornalista norte-americano Joseph Campbell (2001) associa a editoria de esportes a áreas predispostas ao exagero, devido à disponibilidade dos temas do cotidiano em que excessos, escândalos e sensacionalismo suscitam mais polêmicas em meio a manifestação de paixões. Para Salaverría (MORTEIRO, 2017), existem cuidados que o jornalista deve ter com relação às publicações em redes sociais:

Isso tem enormes perigos. Primeiro, que o padrão informativo esteja contaminado por muitas mentiras e, no jornalismo, o fundamental é trabalhar com a verdade. E o padrão atende aos gostos do usuário, que nunca são desafiados por ideias diferentes e abordagens divergentes ao seu modelo de vida. (Tradução nossa) ${ }^{30}$

A análise preliminar sobre o conteúdo noticioso do $\mathrm{COB}$ e a diferenciação das pautas esportivas olímpicas multifacetadas pode ser resumida no quadro a seguir:

\footnotetext{
${ }^{30}$ No original, em galego: "Isto ten enormes perigos. Primeiro, que a dieta informativa estea contaminada por moitas mentiras e no xornalismo o fundamental é traballar coa verdade. E a dieta atende aos gustos do usuario, que nunca se ve desafiado por ideas distintas e formulacións diverxentes co su modelo de vida".
} 
Quadro 4 - Interfaces da pauta esportiva com outras áreas

\begin{tabular}{|l|l|l|}
\hline \multicolumn{1}{|c|}{ TEMA } & \multicolumn{1}{|c|}{ EDITORIA PRÓPRIA } & \multicolumn{1}{|c|}{ ASSUNTO } \\
\hline Personalidades & $\begin{array}{l}\text { Sim (narrativas e entrevistas com } \\
\text { pessoas da convivência) }\end{array}$ & $\begin{array}{l}\text { Especial sobre a conquista de títulos } \\
\text { em determinada modalidade; } \\
\text { nascimento ou morte de atletas. }\end{array}$ \\
\hline $\begin{array}{l}\text { Resultados (medalhas, } \\
\text { recordes, vencedores e } \\
\text { perdedores) }\end{array}$ & $\begin{array}{l}\text { Sim (assunto típico da pauta esportiva } \\
\text { olímpica, recorrente na cobertura dos } \\
\text { Jogos Pan-Americanos). }\end{array}$ & $\begin{array}{l}\text { Vencedores, perdedores, classificados } \\
\text { para etapas finais, placar. }\end{array}$ \\
\hline Convocações & $\begin{array}{l}\text { Sim (esporádico, depende de de } \\
\text { temporadas, tem perfil breve e dá lugar } \\
\text { a especulações). }\end{array}$ & $\begin{array}{l}\text { Campeonato Mundial; equipes de } \\
\text { modalidades pouco conhecidas } \\
\text { classificadas para determinado torneio. }\end{array}$ \\
\hline Valores olímpicos & $\begin{array}{l}\text { Sim (ao contrário de resultados, trata- } \\
\text { se de uma seção rara). }\end{array}$ & $\begin{array}{l}\text { Fair play, respeito, superação, opinião } \\
\text { do (a) próprio (a) atleta. }\end{array}$ \\
\hline Uniforme do Time Brasil & Não (seria um assunto de "moda") & Delegação olímpica brasileira \\
\hline $\begin{array}{l}\text { Realização de eventos } \\
\text { esportivos }\end{array}$ & $\begin{array}{l}\text { Mista (envolve política, economia e } \\
\text { turismo). }\end{array}$ & $\begin{array}{l}\text { Jogos Olímpicos do Rio de Janeiro } \\
\text { 2016 }\end{array}$ \\
\hline
\end{tabular}

Fonte: elaboração própria

Os Jogos Olímpicos de 2016 do Rio de Janeiro trazem uma bagagem contextual própria do movimento olímpico contemporâneo, a partir do ideal de Pierre de Frédy - o barão de Coubertain - que, no alvorecer do século XX, durante a fundação do evento esportivo internacional, idealizou a valorização da participação, da amizade e da excelência entre os atletas (COB, 2007). Em contrapartida, as competições cobertas pela mídia apresentaram proximidade com a teoria do jogo a partir das considerações de Huizinga (2012, p.101), na década de 1920:

Chamar "jogo" à guerra é um hábito tão antigo como a própria existência dessas duas palavras. Já colocamos o problema de saber se isso deve ser considerado apenas uma metáfora, e chegamos a uma conclusão negativa. O mais provável é que em toda a parte a linguagem tenha definido as coisas dessa maneira, a partir do momento em que surgiram palavras para designar o jogo e o combate.

Esses termos não divergem apenas do ideal do olimpismo, como também demonstram uma tênue e tensa relação entre "competição olímpica" e "jogo esportivo de campeonato". A cultura brasileira absorveu, em parte, as características multifacetadas da pauta esportiva, com a metáfora de que o esporte se confunde ou se traduz em futebol. Durante o período de Olimpíadas do Rio, esperava-se que o paradigma fosse subvertido, com o esporte sendo traduzido como um todo, ou melhor, por uma diversidade de práticas e atividades esportivas. 


\subsection{O site do Comitê Olímpico do Brasil in loco: visita técnica}

Este item descreve a visita técnica realizada nas dependências da sede do Comitê Olímpico do Brasil (COB), na cidade do Rio de Janeiro, em 17 de maio de 2017. A pesquisa sobre o site do $\mathrm{COB}$, descrita no item anterior, determinou a base para a visita e para as entrevistas. Como complemento, foram levantados dados sobre os entrevistados, conforme contato anterior por e-mail e telefone, entre 12 de abril a 09 de maio de 2017.

No trabalho in loco, foram percorridos setores, entre os quais o departamento de arquivo (com painéis autografados por atletas e uma biblioteca voltada ao esporte olímpico). Com a finalidade de comprovação dessa visita, foram feitas fotografias dos locais (imagens 9 a 14).

Figura 9 - Átrio de conteúdos

com mural de atletas, mesas de trabalho e biblioteca (no mezanino)

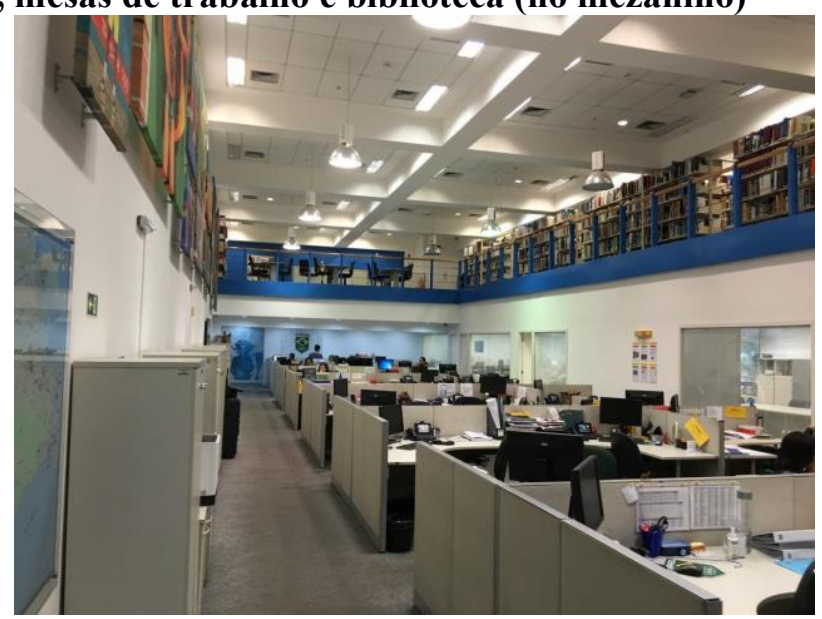

Foto: Carlos Augusto Tavares Junior

Figura 10 - Mural com atletas de destaque olímpico no COB

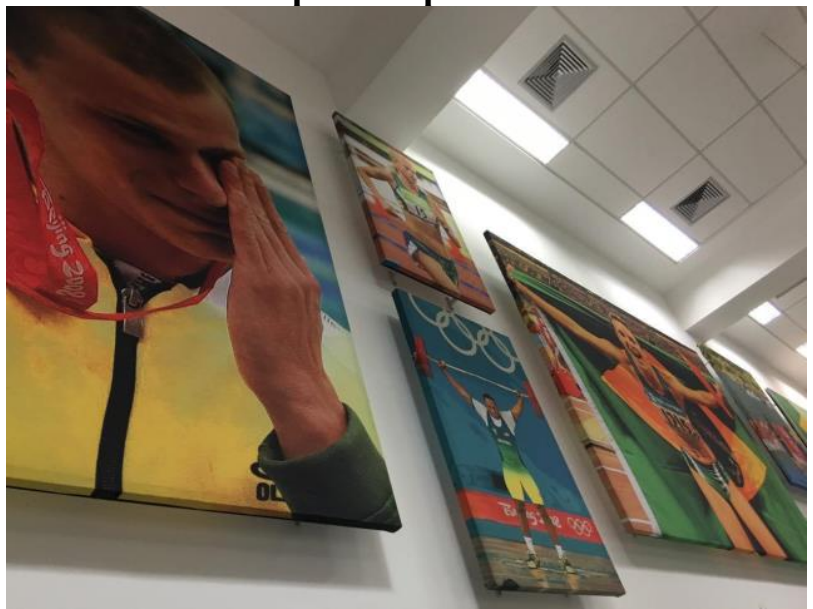

Foto: Carlos Augusto Tavares Junior 
Figura 11 - Acervo bibliotecário voltado aos esportes olímpicos

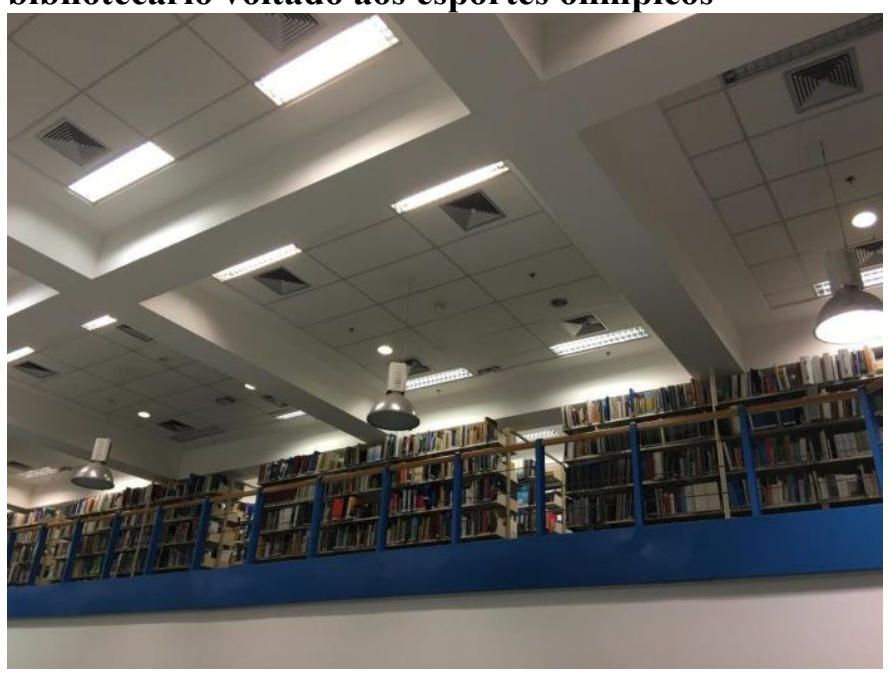

Foto: Carlos Augusto Tavares Junior

Figura 12 - Corredor de acesso

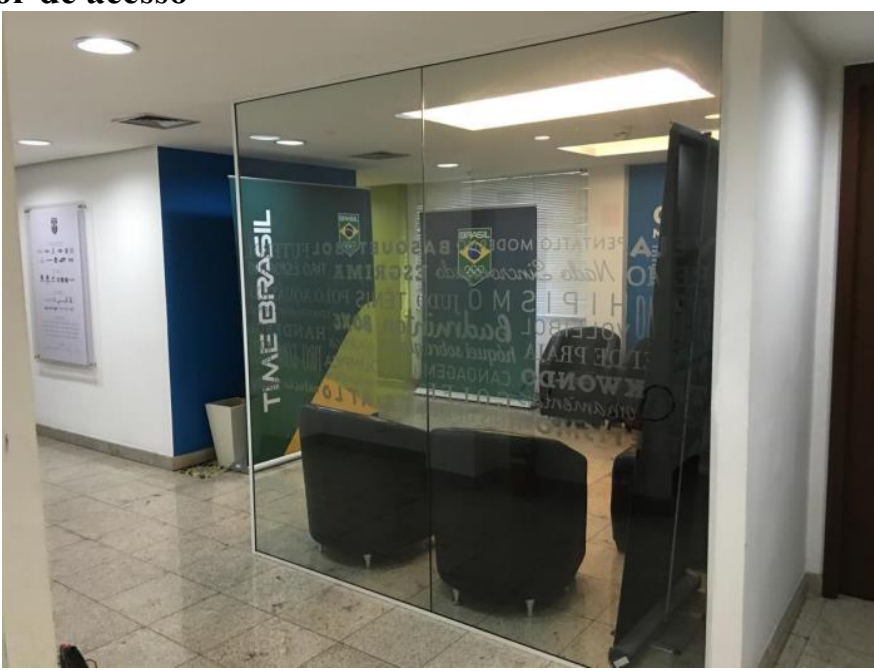

Foto: Carlos Augusto Tavares Junior

Figura 13 - Salas de reuniões

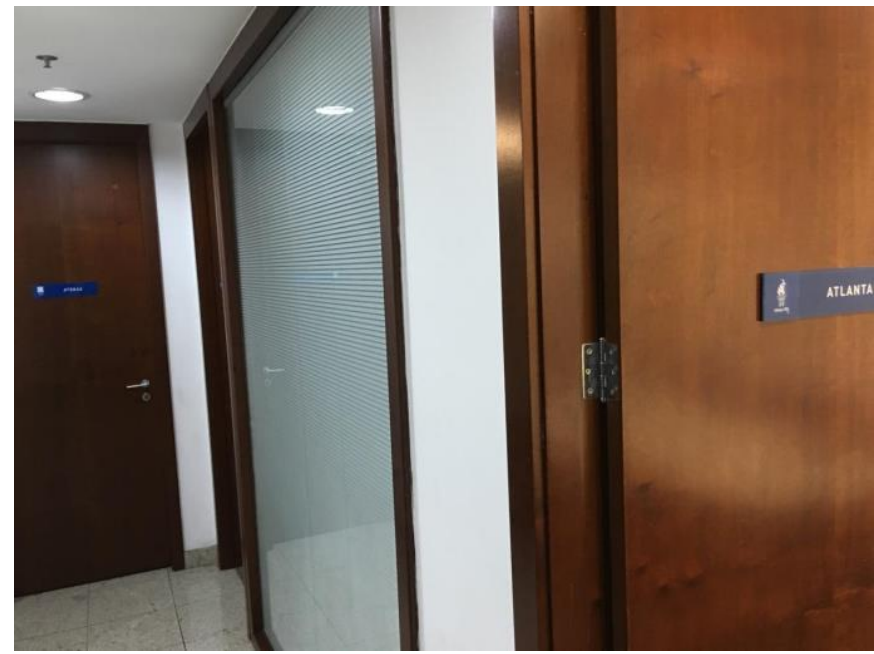

Foto: Carlos Augusto Tavares Junior 
Figura 14 - Jornalistas do Comitê Olímpico do Brasil.

Da esquerda para a direita: Winckler, Motta e Dawes

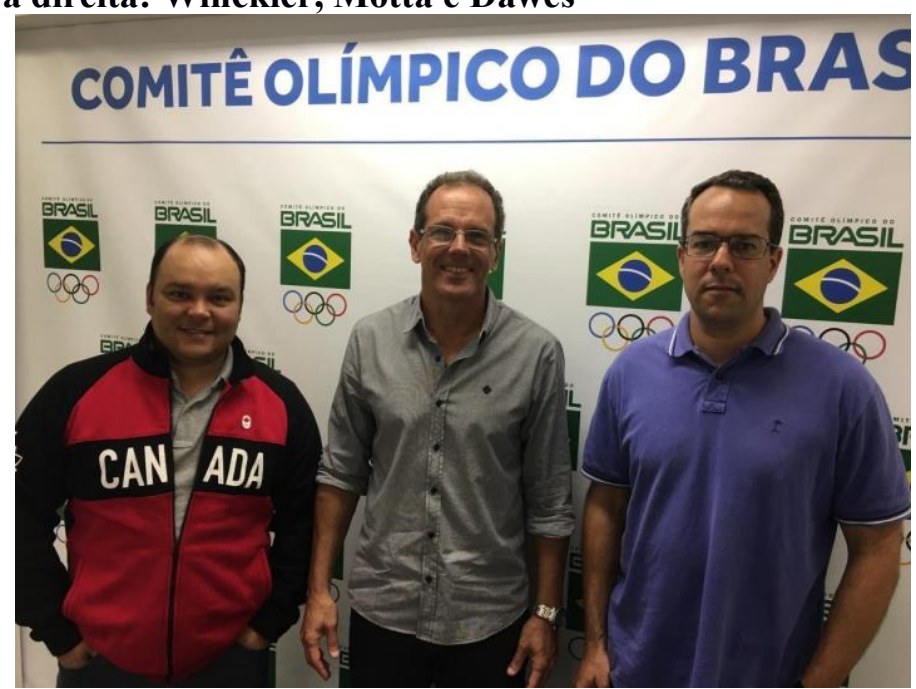

Foto: Carlos Augusto Tavares Junior

Após a apresentação das dependências, ocorreu a reunião com os responsáveis pelo site do $\mathrm{COB}$, escolhidos pela instituição para responder às perguntas específicas desta tese.

- Cláudio Motta: gerente de Comunicação do COB. Jornalista graduado pela Universidade Federal Fluminense (UFF), com pós-graduação em Comunicação Empresarial pela Faculdade Cândido Mendes. Iniciou seus trabalhos em 1986, influenciado pela conquista da medalha de prata pela Seleção Olímpica de Voleibol até que, em 1988, teve a oportunidade de atuar na assessoria de imprensa da Confederação Brasileira de Vôlei. Com passagem pelos jornais O Globo e Diário Popular, em 1999 chegou ao Comitê Olímpico do Brasil.

- Christian Dawes: supervisor de Relações com a Imprensa. Graduado em jornalismo pela UFRJ. Ingressou no recém-lançado jornal esportivo Lance! em 1997. Dois anos depois, passou a atuar no COB.

- Adriano Winckler: supervisor de Conteúdo do site. Graduado em jornalismo pela Universidade Estácio de Sá, com pós-graduação MBA (Master Business Administrator) pela Faculdade Trevisan. Atuou como repórter no jornal O Globo, com passagem pelo portal Agência Estado (AE), além da criação de empresa própria de assessoria de imprensa. Sua chegada ao COB ocorreu em 2012, quando começou a coordenar a produção do site da instituição.

A reunião aconteceu na sala de imprensa, onde se dá a produção do material jornalístico do $\mathrm{COB}$ repassado à mídia brasileira e internacional. A visita durou pouco mais de uma 
hora. As perguntas aos responsáveis pelo site do COB foram planejadas de acordo com o levantamento do primeiro capítulo, tendo por base questões feitas a professores e jornalistas sobre o desenvolvimento da pauta olímpica no Brasil e o significado do jornalismo esportivo.

As entrevistas foram necessárias para o esclarecimento de alguns questionamentos ocorridos durante a pesquisa - e que estão diretamente relacionadas ao sítio do $\mathrm{COB}$ - como destinatários, conteúdo produzido, multiplataformas e o trabalho da equipe de jornalismo.

\subsubsection{Destinatários (público-alvo e/ou usuários)}

A pergunta inicial teve o objetivo de verificar junto aos jornalistas do Departamento de Comunicação do $\mathrm{COB}$ a finalidade da veiculação de notícias pelo site, de modo a identificar um perfil de público: desde a abrangência a qualquer internauta até a possibilidade de destinação a assessorias voltadas a empresas e outros canais de comunicação.

A quem se destinam as notícias veiculadas no site do COB? Esta foi a primeira pergunta colocada aos jornalistas. Cláudio Motta (2017) responde que o espaço consiste num portal do COB com vários propósitos:

Um deles, obviamente, é o conteúdo jornalístico. É fazer chegar as notícias do esporte, de todas as modalidades que a gente conseguir [divulgar] ao alcance do torcedor brasileiro, do fã do Time Brasil [atletas do COB]. Além desse conteúdo jornalístico, o site tem um compromisso com transparência: o Comitê Olímpico do Brasil recebe dinheiro público através da Lei Agnelo Piva e existe uma preocupação muito grande da entidade em dar transparência ao uso desses recursos, com a publicação de relatórios anuais; também no que tange às licitações que são feitas através do site do $\mathrm{COB}$ e todo tipo de satisfação pública que o $\mathrm{COB}$ pode dar através desse seu portal, que é o site.

Ao falar especificamente sobre o conteúdo jornalístico, Motta (2017) revela que o Comitê não tem a pretensão de brigar com grandes portais de internet, com UOL, Globo Esporte, Terra e IG, muito menos com bloggers especializados em determinadas modalidades:

A nossa preocupação é, primeiramente, ser um canal de divulgação das ações do Comitê Olímpico do Brasil em prol do desenvolvimento do esporte e, também, estender essa possibilidade às notícias das confederações brasileiras olímpicas. De certa forma, [somos] um local 
onde o público - fã dos esportes, os jornalistas que cobrem o esporte, as próprias confederações e também patrocinadores que investem no esporte olímpico - tenha uma informação como referência.

Segundo Motta (2017), o COB tem como principal compromisso a credibilidade, ou seja, fazer chegar ao público (fontes, torcedores, patrocinadores, governo - no caso, o Ministério dos Esportes) e, sobretudo, à imprensa, notícias provenientes de fontes altamente confiáveis:

O que você vai ler no site do COB é digno de ser confiável. Nós não publicamos notícias infundadas ou tendenciosas ou que tenham outro viés que não seja prestar informação à sociedade. Essa é a principal característica jornalística do site do COB. Além das notícias, nós também oferecemos fotos de altíssima qualidade dos eventos de que o COB participa, com fotógrafos da mais alta linha do fotojornalismo brasileiro. Então, é um serviço a mais que prestamos, nesse caso, para a imprensa poder ter um material de qualidade e gratuito, pois uma coisa complementa a outra.

Christian Dawes (2017) revela que o COB fornece textos e fotografias para a imprensa. Porém, ele critica a monocultura do futebol no Brasil, o que dificulta até a captação de patrocínio e a visibilidade de outras modalidades. Para ele, o COB tem mais outra proposta: "formar uma cultura mais ampla, de consumo de esportes, de valores olímpicos dentro dos jornais e dos veículos de comunicação”.

A partir dessa perspectiva, o COB também funciona como uma agência de notícias e fotos. Ele revela que, no caso dos Jogos no Rio de Janeiro, por terem sido realizados no País, vários jornais brasileiros cobriram o evento e, para essa situação, diversos credenciamentos foram feitos com jornalistas nacionais, já que "havia a obrigação da cobertura no próprio País". Dessa forma, ele assinala o aspecto local da cobertura.

Dawes (2017) pondera, em edições anteriores de outros eventos, como os Jogos Panamericanos, a dificuldade de se colocar uma matéria nos próprios jornais:

O pessoal não tinha equipe para isso e não enviava pessoas para fora. Então a gente começou um trabalho há muito tempo, de fornecer esse tipo de informação gratuita e, dessa maneira, a abastecer os produtores de conteúdo com notícias das modalidades olímpicas.

Adriano Winckler (2017) considera essencial a responsabilidade do COB de não ser um comitê olímpico do vôlei ou um comitê olímpico do futebol, mas de todas as 
modalidades:

Nós temos a responsabilidade de que todas as modalidades sejam tratadas da mesma forma. É óbvio que algumas modalidades, para o torcedor, tenham um pouco mais de relevância. Ou seja, a pessoa gosta mais de basquete ou gosta mais de natação. É isso o que o COB busca: conseguir inserir num contexto nacional todas as modalidades com a devida importância. Por exemplo, não é porque um atleta joga na NBA que ele tem mais relevância do atleta que treina ciclismo diariamente. Essa é uma responsabilidade do Comitê e a gente luta para conseguir.

Motta (2017) destaca ainda que a atuação do COB com tal extensão começou em 1996, nos Jogos Olímpicos de Atlanta, quando ocorreu a primeira experiência de produzir notícias e distribuí-las para os jornais e a todos os veículos de comunicação.

Dawes complementa ao revelar que, a partir de 1999, nos Jogos Pan-americanos de Winnipeg, o COB ampliou esse conceito: formou-se uma equipe, com uma agência com jornalistas de grandes veículos, com a contratação de profissionais para o período dos Jogos e, ao mesmo tempo, fornecendo material de graça. Ele avalia que começou a se criar uma cultura que foi se desenvolvendo, ganhou destaque nos Jogos Pan-americanos do Rio de Janeiro, em 2007, e se consolidou nos Jogos Olímpicos. Segundo Dawes (2017):

É importante falar do começo de tudo isso: nosso objetivo de colocar mais informação olímpica nos jornais e nos veículos de comunicação e, a partir daí, criar uma cultura também: não é só o consumo da matéria ou o consumo do esporte, dessa maneira... Como Comitê Olímpico do Brasil, queremos, através dessas notícias, passar os valores olímpicos.

Motta e Dawes destacam que o site do COB surgiu em 1999, durante os Jogos de Inverno em Winnipeg, por meio do provedor gratuito Zip.Net ${ }^{31}$ e, ao longo dos anos, se aperfeiçoou junto com o aprimoramento da internet e do consumo de informação digital.

Motta (2017) destaca outra característica importante do conteúdo jornalístico do site do COB: ele abastece todos os outros canais no Facebook - o canal do Time Brasil no Facebook, o canal do Time Brasil no Twitter; o próprio canal do Time Brasil no YouTube:

Quando temos uma pauta jornalística, trabalhamos essa pauta em toda a sua potencialidade: é o depoimento do atleta, do técnico que vai ser colocado como texto no site do $\mathrm{COB}$, a gravação desse mesmo conteúdo

\footnotetext{
${ }^{31}$ A empresa Zip.Net atuava no Brasil como provedor gratuito de sites e e-mails. A marca foi adquirida e incorporada pelo provedor UOL (Universo Online) em 2001.
} 
para o Facebook, a transcrição de trechos dessa entrevista para o Twitter.

A equipe de jornalistas da instituição também trabalha com a perspectiva de comunicação integrada. "Esse material jornalístico produzido pelo $\mathrm{COB}$, especialmente, também serve para abastecer as mídias sociais do COB”, relata Winckler (2017). Desde o início do site, em 1999, havia uma administração externa, que não era do próprio COB, mas o controle interno ocorreu um ano depois. "O COB passa a cuidar diretamente do seu conteúdo em 2000, a internet não era essas coisas", explica Motta (2017).

Entre os detalhes das mudanças do jornalismo do Comitê em relação à produção de informação, Motta (2017) destaca o uso da tecnologia, no início da década de 2000, quando as notícias eram mandadas por fax, como releases, aos veículos de comunicação. Nesse período, o principal meio de acesso ao ciberespaço era o computador e antes do surgimento das redes sociais, em 2004, e da popularização dos blogs de jornalistas, em 2005, a tecnologia adotada para reportagens era o fac-símile, que realizava impressão térmica em papel por via telefônica, com uma interferência indireta de usuários somente ao transmitir e enviar fotocópias. Segundo Motta (2017): “a internet estava engatinhando: em 2004, a imprensa tradicional, em papel, era muito forte e a imprensa digital já estava surgindo com alguma força naquele período".

Por questões de falta de credenciais naquele momento, o provedor e portal de conteúdo UOL - que já atuava na produção de notícias na comunicação digital e despontava com relativa força - ficou de fora. Motta (2017) relembra que a distribuição dos credenciamentos acontecia com menos prioridade nas mídias digitais:

Por quê? Nós recebemos, digamos, 50 credenciais e tínhamos que atender O Globo, Estadão, Folha, Correio Braziliense, Zero Hora, O Dia, revista $V e j a . .$. A mídia tradicional era muito forte ainda e nós não tivemos como atender a mídia digital, através do UOL, o principal expoente naquela época [...] O UOL ficou bastante chateado, porque eles tinham projeto de mandar repórter. Acho que até mandaram sem credencial e deram porrada no COB.

Motta ainda destaca ocorrência de protestos, por parte dos principais provedores que, em 2004, levantaram uma bandeira altamente legítima: "Eles não entenderam que nós, naquele momento, não abrimos mão de algo tradicional, e eles tiveram os motivos deles, e hoje entendemos que estavam no direito de reclamar", esclarece.

Em 2008, a imprensa digital e os portais ganharam relevância e foram beneficiados pelo COB com as credenciais olímpicas. A partir de então, a comunicação pela internet 
envolvia-se no processo e o site do Comitê acompanharia tal crescimento. Na cobertura dos Jogos Pan-Americanos de 2007, havia uma grande equipe e, em seguida, com a vitória da candidatura olímpica, o sítio do COB mantém-se em um nível de crescimento e de fluxo de informações como um grande portal de entrada. Dawes (2017) destaca:

É claro que nos momentos de Jogos, quando mais se produz conteúdo, precisamos reforçar nossa equipe com profissionais externos. Por exemplo, nos Jogos Pan-Americanos, precisamos contratar profissionais externos para nos ajudar na produção in loco das notícias.

Motta (2017) relembra os Jogos Olímpicos do Rio de Janeiro como "contingente maior", devido aos eventos de 2016 acontecerem "em casa". Há ainda o destaque à integração da equipe:

Eu [Cláudio Motta] sou o gerente [de Comunicação]. O Adriano [Winckler] é o editor, que conta com um repórter que ajuda na produção de notícia, de toda a verificação de conteúdo. A parte de [assessoria de] imprensa, é do Cristian [Dawes] e do Daniel [Varsano], que produzem conteúdo que também vai para o site do COB.

Dessa forma, o conteúdo jornalístico do Comitê conta com quatro pessoas que dão suporte jornalístico ao site do COB, tendo à frente o editor Adriano Winckler. O grupo, além de produzir as notícias, capta as informações das confederações para a republicação ou reedição. Motta (2017) também detalha não haver uma colaboração desse sítio com o Olympic Broadcasting System (OBS) porque este contempla apenas os direitos de televisão: “O COB não tem esses direitos e todo o conteúdo que é feito para a TV ou rádio envolve a compra dos direitos de transmissão".

O OBS produz material para as empresas que possuem os direitos de transmissão e também elabora um pequeno material para aquelas que não os adquiriram. Nesse caso, um conteúdo limitado. Para Winckler (2017), a diferença entre o jornalismo do Comitê Olímpico do Brasil ocorre na confecção do material destinado às transmissões em emissoras credenciadas junto ao Comitê Olímpico Internacional: "Como o COB não tem os direitos de transmissão, ele não compra... Não é o seu papel e nem tem dinheiro para isso porque são negociações que envolvem milhões de dólares".

Segundo Motta (2017), o COB não produz material olímpico de televisão e rádio. "Você pode pesquisar e não vai encontrar matérias jornalísticas de TV nem de rádio, justamente em respeito a essa regra do COI, que delibera esse uso somente para as empresas 
que adquiriram os direitos de televisão", acrescenta, referindo-se, sobretudo, à cobertura de competições.

Em suma, os três entrevistados revelam os seguintes pontos para conquistar o público do sítio do COB: ter credibilidade e ser um canal de divulgação dos esportes que revele os valores olímpicos e, em meio ao contexto das mídias digitais de 2016, forneça informações gratuitas. Além disso, divulgar as notícias das modalidades de forma equilibrada, não concorrendo com outras emissoras. Também ter compromisso com a transparência para atingir o principal objetivo: o acesso público ao conteúdo produzido pela equipe nas diversas mídias, entre elas, o website, as redes sociais e os releases (para a imprensa).

\subsubsection{Conteúdo jornalístico do site}

A segunda questão abordada com os jornalistas do COB empreendeu uma busca pelos aspectos da produção de conteúdo no site e tentou traçar um perfil sobre a atuação, o tipo de interação com usuários (a partir do âmbito dos jornalistas envolvidos na publicação das informações), bem como o tratamento desse material no processo de produção da notícia (HOHENBERG, 1981).

Motta (2017) considera que o COB tem alguns públicos-alvo e o principal deles - o fã de esportes - busca as informações por que se interessa. Assim, no site, há a possibilidade de se achar notícias sobre os mais variados esportes. Motta (2017) analisa a cobertura olímpica no Brasil: "sabemos que a mídia tradicional e até de internet, embora não tenha o problema do espaço em papel, também dedica pouco espaço às notícias das modalidades".

Normalmente, a imprensa se dedica a uma modalidade pouco conhecida em momentos problemáticos, como o doping, a prestação de contas ou eleições em determinadas instituições esportivas. Entretanto, o sítio do COB trabalha de outra forma. De acordo com Motta (2017):

O torcedor que busca notícias sobre esportes, sobre seus ídolos, sobre os atletas e sobre as modalidades tem a chance de acompanhar, de certa forma, o que está acontecendo nos esportes. Então, basicamente, é para o fã do esporte.

Para Dawes (2017), o canal do COB está voltado para abastecer a imprensa de informações com ênfase no trabalho do Comitê para o desenvolvimento do esporte: "há projetos e ações para ajudar e melhorar a prática do esporte em alto rendimento, que é um 
compromisso direto do $\mathrm{COB}$ com a sociedade e, sobretudo, com a imprensa".

$\mathrm{O}$ acesso de outros públicos que navegam no site do COB também provém da busca por informações institucionais, a partir da fonte oficial e, nesse caso, relacionadas à transparência: prestação de contas e utilização dos recursos da Lei Agnelo Piva.

Motta (2017) destaca o fã dos esportes e a imprensa como os dois principais públicos-alvo do portal do COB. Winckler (2017), por sua vez, contempla um panorama mais romântico sobre o trabalho da assessoria: "É a importância de levar para o torcedor, para o fã, a certeza de que no site do COB ele vai encontrar notícias do esporte de que gosta".

O compromisso com a notícia proveniente de uma informação crível visa estabelecer o próprio Comitê como fonte. Winckler (2017) ressalta que a equipe não tem como mensurar se o portal tem mais acessos por parte de fãs de basquete, de natação etc. Para ele, certamente, para quem escreve a notícia sobre um esporte ou uma modalidade há uma certeza: alguém irá acessar o conteúdo. Motta (2017) reforça isso:

Para nós, isso vai além de todos os públicos, pois há a parte legal, do Tribunal de Contas da União, e as confederações. Creio que o fã seja o nosso grande público - e a imprensa [também], para poder divulgar essas informações.

Dawes (2017) aborda a responsabilidade que a equipe do site tem em fomentar gerações de futuros atletas:

Gosto muito de cobrir os Jogos Escolares da Juventude. O COB realiza duas etapas nesse evento e ali sinto o poder que a imprensa tem de, muitas vezes, revelar um garoto, de mudar a vida de um moleque. Vou para as ruas com nossa equipe para buscar histórias legais: não só quem ganhou ou quem perdeu, mas contar a história de um garoto que está buscando, no esporte, melhorar sua vida e muitas vezes o destacamos e isso vai parar num Globo.com, Globoesporte.com. A partir dali, passa a ter visibilidade; a pessoa vai participar do prêmio Brasil Olímpico, ganha algum prêmio pelos melhores que conquistou e, claro, todo seu trabalho ali... É uma responsabilidade que temos!

Quando Motta (2017) sugere que sejam passados alguns exemplos de crianças que se transformaram em atletas olímpicos, Dawes menciona o nome de alguns que começaram a se profissionalizar após os Jogos Escolares da Juventude e que foram anteriormente abordados em notícias produzidas e publicadas pelo COB. Segundo Dawes (2017):

Matheus Santana e Sarah Menezes passaram por aqui. Eles passaram pelos Jogos Escolares e estamos ali, pegando esses moleques bem novinhos e 
dando destaque e visibilidade e, a partir daí, pode vir patrocinador, uma atenção maior da Confederação. Esse também é o nosso trabalho.

Diante do contexto da pauta no Brasil, tópico tratado no capítulo anterior, a equipe de jornalistas analisa os valores - mote do olimpismo - como o respeito, a amizade e a excelência. Segundo o editor do site, Winckler, os valores olímpicos norteiam a atuação do COB em qualquer situação. Para Winckler (2017), uma notícia que os repórteres do COB publicaram fica diferente daquela publicada em outro jornal.

Deixa eu fazer uma crítica mais técnica: o COB busca mostrar os valores, mas [na notícia] não vou dizer que é uma preocupação - nesse jogo eu vou ter que mostrar o companheirismo, o coletivismo... Não tenho como te demonstrar isso, mas os valores olímpicos norteiam todo o trabalho do $\mathrm{COB}$, isso em qualquer área.

Motta (2017) complementa a fala de Winckler com as tipificações sobre cobertura jornalística e a questão do emprego dos ideais nas matérias produzidas: "Esses valores que o Adriano [Winckler] falou, já estão intrínsecos no dia a dia do COB”.

A menção do trabalho de preparação de um atleta para os Jogos Olímpicos também envolve a questão de patrocínio como garantia sobre a obtenção de medalha. Segundo Motta (2017):

Você pode investir o dinheiro que for em alguma modalidade e ninguém
garante que aquele atleta vai ser campeão olímpico ou então medalha de
prata ou medalha de bronze. E nem por isso esse resultado diminui o
trabalho que é apresentado no resultado dos Jogos Olímpicos é resultado
de um amplo trabalho feito pelo COB, pelas confederações, pelas equipes,
pelos atletas, pelas equipes multidisciplinares que circundam esse atleta -
são dezenas de profissionais envolvidos naquele resultado final, que pode
ser uma medalha, que pode ser um quarto lugar, que pode ser uma final
olímpica.

Outra diferença quanto ao tratamento das informações se evidencia a partir da abordagem sutil nas pautas que acompanham as competições ou mesmo do que se publica e se transmite na mídia impressa e audiovisual. Ou seja: além das informações sobre o resultado, o trabalho de preparação de atletas ganha importância e atenta à discussão sobre a coletividade nas atividades de treinamento entre esportistas, técnicos e auxiliares. "Quando falamos de valores olímpicos, é [preciso] tentar mostrar para o público e, sobretudo, para a mídia, que é muito imediatista e vive muito em função de resultados”, alerta Motta (2017). Desse modo, a menção de determinado resultado final emerge como fruto de algo muito 
maior, justamente para servir de crítica para melhorar a performance do atleta, no caso de uma competição.

Os valores olímpicos nas reportagens produzidas e divulgadas pelo Comitê, por meio do site, surgem em aspectos singelos, segundo a explicação de Motta (2017):

Esses valores olímpicos estão muito subliminares: estamos falando de ética, de respeito, de amizade, de congraçamento, de respeito às regras; estamos falando de coisas muito conceituais e que o COB preza assim, no seu dia a dia, e procura refletir intrinsecamente através do conteúdo que publica.

No caso de doping, o COB não os tolera e, nessa situação, uma notícia publicada no sítio com esse tema incluirá críticas a atletas, técnicos e demais envolvidos. Motta reforça que o COB "é o primeiro a questionar e recriminar esse tipo de atitude". No caso de atletas flagrados durante uma competição realizada pela instituição, Motta (2017) destaca a forma de atuação da sua equipe: "O $\mathrm{COB}$ enfrenta essa dura realidade com coragem, sem se esconder, sem passar a mão na cabeça e sem remediar aquela situação".

Paralelamente ao doping, a possibilidade reviravolta permeia valores olímpicos e tabus, como o ceticismo e a desconfiança diante a um apoio na situação de recomeço. "A questão é muito individual, mas, certamente, eles [atletas] têm o apoio da sua confederação e do COB, apoiando diretamente ou indiretamente essa confederação, para dar a volta por cima”, explica Motta (2017).

A reviravolta de atletas também depende da questão subjetiva. Motta (2017) menciona a história de outro esportista que "foi lá, no fundo do poço" e conseguiu se reerguer no Rio 2016: Diego Hypolito. "Em determinada olimpíada, Hypolito despontava como favorito e, devido a um erro de execução final do exercício, perdeu pontos preciosos e sequer conseguiu medalha". Na olimpíada seguinte, por causa de um erro de execução, ele "caiu de cara no tablado". Para Motta (2017), a iniciativa da reviravolta de Hypolito teve êxito porque:

Foi o primeiro a ter muita coragem de enfrentar essa situação, de admitir que errou. O problema não era da confederação, nem do COB... Teve todas as condições de treinamento para se preparar, para chegar aí [nas duas Olimpíadas] e que foi um erro individual, que ele não se perdoava por isso. E ele, depois, oito anos mais velho, aqui no Rio 2016, consegue uma medalha de prata, justamente nas provas [competições] em que ele tinha sido condenado, quase que para sempre. 
O caso de superação de Diego Hypolito teve apoio da Confederação de Atletismo, do $\mathrm{COB}$, além das equipes de ginástica, psicologia e fisioterapeutas. "Foram mais de 30 cirurgias pelo corpo [...] um atleta quase que biônico. Ele reconhece o apoio e teve coragem suficiente para dar essa volta por cima", ressalta Motta (2017), que acrescenta sobre as notícias publicadas no site: "Não há uma preocupação nossa de, em cada texto, destacar a ética, a solidariedade, o respeito... Tudo isso já está intrínseco na própria dinâmica do esporte".

Winckler menciona que, teoricamente, ao entrar no site do $\mathrm{COB}$, o usuário consegue perceber a existência de três minissítios: um do Comitê Olímpico, um do Time Brasil e outro com os Jogos Escolares. Winckler (2017) conclui:

Se o usuário der uma busca, vai ver que tem várias ações do COB e que a parte institucional está contemplada ali. Nosso forte são as modalidades, as competições, nossos atletas... Valorizamos o esporte.

A impressão de que o COB tenha evitado ou ignorado assuntos polêmicos na forma de notícia no site não significa que o Comitê lançaria mão do direito de resposta que lhe cabe por conta do processo de comunicação a partir linhas editoriais da mídia, conforme a explicação de Dawes (2017):

Faz parte do relacionamento com a mídia. Essa relação é muito tênue: ambas as partes estão sempre propensas ao erro, e a mídia também. Então, quando o $\mathrm{COB}$ se viu atingido injustamente, procurou-se o direito de resposta, não na Justiça.

Motta (2017) ressalta essa busca direta na linha editorial em canais que os jornais e os órgãos oferecem. Por exemplo, a Folha de S.Paulo, que tem a coluna 'Erramos', em que reconhecem os possíveis erros: ou porque subiram o tom das críticas ou porque erraram na informação. "Então, por meio desses canais, buscam se posicionar", relata. Já para Dawes (2017), a notícia institucional existe, sim, na página, embora não seja o foco. "Procuramos dar mais uma cara de [canal de] esporte para o site", esclarece.

Ao sintetizar os principais tópicos abordados, destacam-se a atuação dos jornalistas do COB na produção de notícias para os usuários-interatores (GARCIA, 2011) do site que procuram informações sobre a modalidade de que gostam, sem pretensão de competir com veículos de comunicação; apoio aos atletas a partir da preparação, com direito a criticá-los em casos de violação grave de normas, como o doping; uso abrandado dos valores olímpicos 
com prioridade de notícias sobre os seguintes temas: atleta, competição e preparação, além de questões institucionais do próprio COB.

\subsubsection{Multiplataformas}

As multiplataformas foram um tópico recorrente na análise das mídias digitais por conta das interações de usuários com jornalistas no processo de produção e divulgação de conteúdo da própria multimídia. Na web, esta questão torna-se presente em espaços destinados à representação social de usuários-interatores (GARCIA, 2011), como redes sociais, blogs, chats e canais do YouTube, como sugere o conceito de Salaverría e Negredo (2008) sobre a linguagem das plataformas web e da notícia em ambiente digital, além dos estudos de Bolter e Grusin (2000), abordados previamente.

Nesse contexto, formulou-se a questão sobre como ocorre a relação dos usuários com os jornalistas do COB. Winckler (2017), editor responsável pelo conteúdo, explicou que, se um usuário-interator (GARCIA, 2011) fizer uma busca no Google ou em outros buscadores, terá entre os resultados as informações publicadas no sítio do COB. Por exemplo, quando o internauta quiser dados sobre uma competição de handebol em 2010, "poderá encontrar essa informação fácil no nosso site", diz, reforçando a importância dos acessos pelo público.

Por sua vez, Dawes (2017), supervisor de relações com a mídia, considera que a abordagem das notícias em espaços cibernéticos reflete uma preocupação: “Tentamos fazer o site ser interessante para todo o mundo, que é um equilíbrio que buscamos aqui". De acordo com ele, enquanto a imprensa formal busca um texto mais completo, com mais declarações, o público jovem, afoito por algo mais direto, também se depara com a informação institucional e histórica. "Então, tentamos dar um equilíbrio para que todo esse público possa circular por ali à vontade", conclui.

Diante da perspectiva de acompanhamento de notícias a partir do COB, também existe uma busca por conteúdo pouco recorrente na mídia impressa e audiovisual. Motta (2017) exemplifica a partir do canal do site destinado aos Jogos Escolares: "Têm dois períodos por ano em que há picos de acesso - e estamos falando de quatro mil jovens em cada etapa, de 12 a 14 anos", diz, referindo-se aos Jogos Escolares.

Os usuários-interatores (GARCIA, 2011) do sítio web constituem um nicho de público não suprido pela mídia tradicional, sem contar com uma devida atenção aos Jogos Escolares. "Existe esse outro público que o COB tem o compromisso de atingir, que são os 
atletas e seus familiares; sua escola e seus amigos, para depois compartilharem essas informações do site do COB para mídias sociais como Twitter, Facebook e YouTube”, revela Motta.

A informação abrangente e multifacetada relacionada a atletas olímpicos torna-se viável por meio do minissítio Time Brasil e isso ajuda nos quesitos de interação de usuários e compartilhamento de conteúdo. Motta (2017) ressalta que ocorrem "muito mais nas mídias sociais do que propriamente na página online do COB”. De acordo com a declaração do jornalista, a interação em âmbito dinâmico na comunicação digital acontece de maneira mais enfática pelas redes sociais, identificadas por meio do perfil Time Brasil no Twitter, Facebook e YouTube.

Considerando esses perfis, principalmente no Twitter e Facebook, Motta (2017) ressalta: "Temos uma resposta mais rápida e mais real dessa expectativa do torcedor". O site do $\mathrm{COB}$ constitui um portal que abastece as informações publicadas nas redes sociais pelo Comitê. Winckler (2017) destaca que o público interessado no conteúdo da página ocorre a partir da faixa de idade. "A pessoa que acessa [o site do COB] tem um pouco mais de idade que o público das mídias sociais".

Em termos comparativos, a interação de usuários a partir do sítio do COB em relação às redes sociais apresenta processos de comunicação distintos. Para Winckler, a resposta pela rede social ocorre imediatamente. “A interação ali é enorme: tanto na caixa [de entrada] como nas postagens e por mensagens diretas para a página", destaca.

Entre os recursos interativos oferecidos pelo site do COB, Winckler (2017) considera como fundamental a seção Fale Conosco, que visa não deixar ninguém sem resposta. Entretanto, em meio a várias mensagens recebidas ao longo dos dias, há casos em que o descarte de respostas mostra-se inevitável, conforme a explicação de Dawes (2017): "Não tem uma resposta... É uma crítica sem pergunta que não tem relação direta com o trabalho do $\mathrm{COB}$, como por exemplo: estourou um cano aqui por causa das obras que vocês fizeram nos Jogos de 2016".

Outro exemplo de comentário não respondido ocorre quando determinado contexto específico afasta-se da área de atuação do Comitê. Motta (2017) menciona a abordagem de temas sem familiaridade com o brasileiro: "Nesse momento, está havendo uma campanha na Coreia do Sul, em função dos Jogos de Inverno, para acabar com o consumo da carne de cachorro".

Entretanto, quando há perguntas dirigidas ao $\mathrm{COB}$ - como alguma dúvida ou algum pedido de ajuda - as pessoas recebem um retorno. Motta (2017) destaca a importância da 
resposta aos usuários e a necessidade de dar atenção ao público: "Nós, como consumidores de qualquer coisa, de comércio ou de serviços, ficamos frustrados quando você faz um input e não recebe resposta".

Diante dessa preocupação, o retorno tem a finalidade de encaminhar aquela pergunta, crítica, sugestão, ao mesmo tempo que o processo de interação ajuda a reforçar o compromisso e a credibilidade do site do COB. Em contrapartida, Dawes (2017) retoma a questão de que o $\mathrm{COB}$ atua no processo de interação com os usuários e não existe uma resposta da equipe jornalística: "Quando alguém acessa o Fale Conosco e diz: parabéns por essa matéria do vôlei, que estava muito legal. Ou... Naquela matéria sobre a partida de rugby, eu estava lá!".

Em algumas situações, a resposta ocorre automaticamente, principalmente quando determinado usuário-interator (GARCIA, 2011) de redes sociais publica um comentário com uma pergunta direcionada, por exemplo, sobre a possibilidade de repescagem de atletas para outra etapa em competições. Nesse caso, as informações complementares ou o link com publicações específicas do site aparecerão no formato de resposta: notadamente em redes sociais como Twitter e Facebook.

Além disso, existem casos de informações específicas sobre atividades em confederações afiliadas ao Comitê. "Eu gostaria de me inscrever no curso da $\mathrm{ABT}^{32}$. Essas informações são da interação do site do COB, mas não é do fã", lembra Motta (2017). Ele salienta também a situação da comunicação digital do COB: usuários interessados em esportes olímpicos fazem o contato diretamente nas redes sociais e jornalistas buscam a informação diretamente nas assessorias de imprensa.

Dawes (2017) exemplifica a destinação de público para cada plataforma:

Cada vez mais estamos jogando nossos discursos jornalísticos para o site do COB e queremos fazer com que a imprensa se acostume a buscar ali, com a publicação de mais material para eles. E queremos que [o site] seja uma referência - e já é uma referência - e que se acostumem a olhar como olham as agências de notícias ou outros sites, que todo dia passem por aqui para ver uma novidade que possa interessar e entrar nos jornais também.

Resumidamente, a maioria das interações com as multiplataformas digitais do COB visa trazer respostas para dúvidas enviadas por usuários, exceto em assuntos deslocados ou opiniões sobre temas generalistas; o trabalho de imprensa do Comitê busca atender

\footnotetext{
32 Academia Brasileira de Treinadores.
} 
jornalistas dos veículos de comunicação e não tem o intuito de funcionar como assessoria; a interação se mostra mais intensa com jovens em redes sociais como Twitter, Facebook e YouTube.

\subsubsection{Trabalho e credenciamentos de jornalistas pelo $\mathrm{COB}$}

A atuação dos jornalistas na cobertura dos Jogos de 2016 foi tema de uma incursão paralela, a partir do acompanhamento do site do $\mathrm{COB}$ em períodos que coincidiram com a elaboração desta tese: antes, durante e após as Olimpíadas no Rio de Janeiro. Despertou atenção a variação da quantidade de notícias publicadas coincidentes com 'janelas' de campeonatos, eventos ou etapas de preparação de atletas.

Durante a visita técnica, foi constatado que nesse período específico o Comitê contou com o trabalho temporário de jornalistas para a cobertura de todas as competições de que os atletas brasileiros participaram, além de um credenciamento restrito à instituição que permitia acesso a treinamentos preparatórios em torno do Parque Olímpico e na área de circulação que dava acesso aos alojamentos desses esportistas.

Pediu-se aos jornalistas do Comitê Olímpico do Brasil que fizessem considerações sobre a quantidade de notícias publicadas durante competições e os acessos ao site em determinados períodos. Mota (2017), gerente de comunicação, explica o planejamento do trabalho da equipe durante os Jogos Olímpicos:

\footnotetext{
Nós tivemos três bases de produção de notícia: no Centro de Imprensa, no Parque Olímpico [na Urca] - pela Escola de Educação Física do Exército que funcionou como a base do Time Brasil e vários atletas se prepararam lá antes e também durante os Jogos - e na Vila Olímpica, onde ficam todos os atletas e fica a missão [comitiva] brasileira.
}

Nesses três locais, foram produzidas notícias para os canais digitais - além do site, as redes sociais como o Facebook e o Twitter. "O COB contou com profissionais altamente tarimbados", relembra Motta, que ressalta sua atuação como coordenador dos trabalhos dos jornalistas no MPC (Main Press Center). Ainda de acordo com Motta (2017):

Tivemos quatro editores e, como os Jogos começavam cedo e acabavam muito tarde, sempre tínhamos duas duplas de editores. Então, a primeira turma começava às sete horas da manhã e ia até, mais ou menos, às cinco horas da tarde; a segunda turma começava as duas horas da tarde e ia até o 
final, à meia-noite, [às vezes] uma hora [da madrugada], por aí.

Nesse ínterim, atuavam simultaneamente quatro jornalistas entre as 14 e 17 horas, quando também trabalhavam quatro editores com o compromisso de não deixar nada de fora: desde os treinamentos, locais de prova, competições e informações específicas sobre os atletas, como o acompanhamento dos exames antidoping. "Isso demonstra essa responsabilidade de atuar em todos os esportes que estão representando o Brasil durante os Jogos", destaca Motta.

Nas ruas do Rio de Janeiro, havia seis repórteres atuando especificamente na região da Barra da Tijuca e sete fotógrafos que produziram o material fotográfico. No entorno do bairro da Urca, o COB contou com um coordenador que prestava atendimento à imprensa e orientava o trabalho de um repórter e de um fotógrafo.

Motta (2017) menciona a atuação dos jornalistas do COB durante os Jogos do Rio de Janeiro:

Quando se fala de produção de notícias, é só a textualização de um trabalho maior que é a imprensa como um todo. Na Vila Olímpica, nós tivemos três assessores de imprensa, que tinham muito esse papel - o Cristian [Dawes] foi um deles - de atender a demanda sobre a delegação brasileira e também produzir notícias geradas de dentro da Vila Olímpica, onde os repórteres e a imprensa não têm acesso.

A imprensa credenciada teve acesso a uma zona internacional: uma área de convivência que os atletas frequentam para fazer compras, adquirir souvenirs olímpicos, alimentar-se ou tomar café. Entretanto, os jornalistas não puderam ingressar na área dos alojamentos dos esportistas brasileiros, como relembra Motta (2017):

Tivemos como produzir conteúdo exclusivo dentro da área residencial desde que não se ferissem os direitos de transmissão - áudio e vídeo - em um local a que a imprensa não tem acesso. E isso é fundamental para dar um olhar que nem a própria imprensa tem, em relação ao trabalho do COB, à missão, exemplo de coisas que acontecem dentro da Vila.

Nesse caso, tornou-se possível acompanhar a rotina de atletas ao saírem para treinar, competir e ainda os testes de medição de lactato ${ }^{33}$ desses esportistas, cujo resultado se dava no dia seguinte ou em questão de horas. "O técnico sabe se aquele atleta está cansado ou

\footnotetext{
${ }^{33}$ Exame médico para a detecção de substâncias que alteram o desempenho de atletas (doping sanguíneo). In: Revista Brasileira de Medicina do Esporte, v.5, n5. Niterói: UFF, outubro de 1999. Disponível em: <http://www.scielo.br/scielo.php?script=sci_arttext\&pid=S1517-86921999000500007>. Acesso em: 29 set. 2017.
} 
não. Então, procuramos, através de nossa equipe dentro da Vila Olímpica, externar esses detalhes que o público não conhece e a que a imprensa, normalmente, não tem acesso", enfatiza Motta (2017).

O esclarecimento sobre diferentes credenciamentos junto aos Comitês Olímpicos do Brasil e Internacional visa compreender como o trabalho dos jornalistas profissionais durante os Jogos do Rio de Janeiro em 2016 pode ser desenvolvido, as limitações e as implicações diante da falta ou da negação do credenciamento.

Durante os Jogos Olímpicos, os jornalistas do COB atuaram como imprensa credenciada, segundo Dawes (2017), com acesso aos locais de competição. Motta (2017) destaca como se deu a distribuição das permissões de trabalho in loco para jornalistas por meio do Comitê Olímpico do Brasil: “Aqui, no Rio de Janeiro, como o Brasil era o paíssede, o COB recebeu uma quantidade de credenciais suficiente para atender toda a imprensa e também atender às nossas necessidades", ou seja, a produção de conteúdo noticioso pela própria instituição. Motta (2017) esclarece os motivos dos credenciamentos:

Como falamos antes, desde Atlanta em 1996, a cobertura é muito cara: você enviar uma equipe ou um profissional a um outro país durante 15, 20 ou 30 dias, às vezes, é muito caro, muito dispendioso. Eu não estava aqui nessa primeira experiência, então, lá atrás, o COB percebeu essa dificuldade e tomou a frente no sentido de produzir notícias para ajudar a cobertura da imprensa na parte de texto e, sobretudo, fotografia, porque se as credenciais de repórter já são escassas, as de fotografia, mais ainda.

Desde então, o COB começou a funcionar como uma agência de notícias que produz onteúdo sobre a participação da missão brasileira por meio de textos e fotografias, como acrescenta Motta (2017):

A imprensa reconhece que o COB se apropria de ' $X$ ' credenciais, que não são muitas, são poucas e, quando os Jogos são lá fora, nós temos dois editores para o site, no máximo quatro repórteres e três fotógrafos para dar conta de toda a delegação. Isso ajuda no trabalho de cobertura dos jornais, revistas e sites de internet que não têm equipes grandes quando as partidas ocorrem no exterior.

Sobre o fato de o evento ocorrer em território nacional, Motta (2017) enfatiza:

Tratando-se de Brasil, é óbvio que todos acumularam força, energia e dinheiro para enviarem suas equipes para o Rio, tanto que o nosso trabalho de agência, digamos assim, ficou, comparativamente com outros Jogos, em segundo plano, porque os veículos estavam aqui em grande número, 
com grandes equipes.

Dessa maneira, a atuação do COB como agência de notícias torna-se ambígua no quesito local, considerando-se os altos custos do acompanhamento in loco das competições em outro país, já que a demanda por informação institucional não se restringe ao site, pois o setor de Relações com a Imprensa busca atender jornalistas e assessorias de imprensa.

A veiculação de notícias no sítio do Comitê Olímpico do Brasil para usuários interessados nos esportes olímpicos, por sua vez, emerge como um enfoque plausível diante do atendimento oferecido aos profissionais da mídia. "O material produzido para o site não teve a mesma audiência, por parte da imprensa, do que teve em Londres [2012], em Pequim [2008] ou do que terá em Tóquio em 2020”, finaliza Motta (2017).

No caso de negação de credenciamento de jornalistas ou empresas de comunicação, esta ocorre a partir da percepção do surgimento de outras áreas de atuação dos profissionais em setores em que o IOC delibera sobre a compra de direitos de transmissão. Segundo Motta (2017):

Envolve a compra de direitos. O credenciamento de rádio e TV não passa pelo COB; é feito diretamente pelo $\mathrm{COI}^{34}$. Então, se você comprou o direito de transmissão, o COI vai dar " $\mathrm{X}$ " credenciais de acordo com o investimento. $\mathrm{O}$ COB só credencia mídia impressa e internet.

O trabalho de profissionais da mídia contemplou a produção de textos e de fotografias em 2016: "Foi assim no Rio e será assim em Tóquio [em 2020]”, salienta Motta, enfaticamente.

Os jornalistas do COB não especificaram exatamente a relação dos profissionais de audiovisual credenciados por meio da compra de direitos de transmissão para os Jogos de 2016. Motta (2017) menciona as emissoras Globo; Sistema Globo de Rádio [CBN]; Itatiaia, de Belo Horizonte; Rádio Gaúcha, de Porto Alegre. Quanto às televisões, a maioria, exceto TV Brasil, Rede TV e CNT, que não adquiriram os direitos de transmissão.

Somente os canais que compraram os direitos obtiveram as credenciais para a cobertura ao vivo dos Jogos Olímpicos no Rio de Janeiro. Por esse motivo, Motta (2017) enfatiza que o credenciamento foi negado, não pelo $\mathrm{COB}$, mas porque a empresa não adquiriu o direito.

Sobre a questão de emissoras de rádio do interior do Brasil terem o pedido de

\footnotetext{
${ }^{34}$ Abreviatura, em português, recorrente na mídia brasileira para Comitê Olímpico Internacional (IOC).
} 
credenciamento indeferido, Motta (2017) esclarece: "Para ser mais preciso na resposta, até existe uma credencial para não detentores que dá acesso limitadíssimo, como ao Centro de Imprensa, mas sem gerar conteúdo nos locais de competição". Essa autorização de âmbito mais limitado deve ser solicitada diretamente pelo IOC.

A partir dessa discussão, são levantadas particularidades sobre a permissão do trabalho de jornalistas in loco e como o COB aparece como alternativa de agência de comunicação, assessoria e credenciadora de profissionais para a produção de conteúdo de texto e fotografia.

Por meio do questionamento sobre como seria o processo de credenciamento, foram obtidas as informações sobre a autorização das equipes de cobertura: o pedido deve ser tratado sem interferência do $\mathrm{COB}$, mas de forma direta e exclusiva junto ao IOC: por meio da compra de direitos de transmissão audiovisual ou como espectador, que pode gerar apenas um boletim para ser veiculado ao final do dia.

Com base no levantamento teórico que sugere que um internauta também adquire, nos meios digitais, a capacidade de prosumer (TOFFLER, 1980) - produtor e consumidor, nesse caso, de conteúdo difundido no ciberespaço - levanta-se a possibilidade de o próprio atleta, eventualmente, envolver-se com a produção e divulgação de material audiovisual, como, por exemplo, a gravação e o compartilhamento de vídeos com telefones celulares, publicados em redes sociais. Desse modo, o próximo questionamento aos jornalistas do COB buscou obter deles considerações sobre atletas e jornalistas na condição de usuáriosinteratores (GARCIA, 2011).

Motta (2017) relembra a recomendação aos atletas sobre o foco nas competições e não se irritarem com críticas e comentários nas redes sociais:

O que o COB fez foi reunir os atletas aqui, na fase de Pré-Jogos, para passar uma série de informações sobre a missão brasileira, e as mídias sociais foram um tema que nós entramos com um aconselhamento como: se você ficar muito tempo na internet, estará deixando de descansar; você vai dormir às duas horas da manhã e essas três horas de sono que você está perdendo vão fazer falta no dia seguinte para treinar ou para competir.

Diante do próprio perfil de atuação do COB, Motta (2017) esclarece ainda sobre a relação da entidade com os esportistas:

Dar plenas condições para os atletas, tipo: "vale a pena ficar perdendo tempo e atenção com isso, deixando de focar no seu ofício que é competir e treinar bem... com prejuízo ao foco?". Então, um aconselhamento foi 
assim: "existem esses dois caminhos: os escorpiões escolhem esse aqui, os campeões se isolam do mundo exterior para conseguir melhores resultados.

Em relação à cartilha de Diretrizes do IOC sobre mídia social e digital: Rio 2016 no site $^{35}$ do COB, Winckler (2017) esclarece tratar-se de um documento do Comitê Olímpico Internacional que estabelece as normas de uso de internet válidas para os profissionais de mídia. Motta (2017) completa essa questão referindo-se à credencial olímpica: "Quando você recebe a credencial, está automaticamente sujeito ao cumprimento daquelas diretrizes que são, justamente, para preservar os direitos das empresas que compraram a transmissão dos Jogos, seja por áudio, seja por vídeo", observa.

Nesse caso, aparecem apenas no site do COB, e em nenhuma outra rede social do Time Brasil, as imagens gravadas nos locais de competição. "Isso é um direito de quem comprou o direito. Os jornalistas de veículo impresso não podem fazer essas gravações e áudios. Não podem transmitir nada ao vivo", finaliza Motta.

A captação de áudio de áudio, no caso de um jornalista da imprensa escrita ou de web apenas com texto e imagem estática, tem a finalidade de atuar como ferramenta para auxiliar o jornalista na produção da reportagem. Motta (2017) exemplifica:

O áudio pode-se gravar na zona mista para depois republicar no seu veículo [impresso]. Por exemplo, se você é um jornalista do Jornal de Piracicaba, estará credenciado para esse veículo e vai à zona mista colher um áudio para a sua matéria. Pode publicar aquela matéria em texto. Agora, você não pode usar aquele áudio para a Rádio Piracicaba.

Essas diretrizes objetivam estabelecer tais questões para qualquer profissional de mídia que venha a ser credenciado: trata-se de regras de uso da internet nos ambientes dos Jogos Olímpicos que não vêm do COB, mas do Comitê Olímpico Internacional, e que valem qualquer veículo, mídia e delegações. Dawes (2017) salienta a existência das diferentes credenciais devido à menção do financiamento dos Jogos Olímpicos ser viabilizada com venda dos direitos:

O COI se defende dessa forma e é um grande desafio para eles, eu acho. As novas mídias estão chegando com toda a força - todo o mundo com o seu celular pode gravar e transmitir ao vivo. Como eles vão lidar com isso ao longo dos tempos? Já vivemos isso; é um combate entre liberar e proibir.

\footnotetext{
${ }^{35}$ Disponível em: <https://www.cob.org.br/handlers/recuperadocumento.ashx?codigo=4539>. Acesso em: 22 nov. 2015.
} 
Vão ser interessantes os próximos passos que eles vão dar.

Motta (2017) esclarece alguns aspectos relacionados ao processo e à organização da comunicação:

\begin{abstract}
Quem trabalha com comunicação, tendo uma matéria-prima sobre o esporte olímpico, o ideal seria ter a informação difundida em todos os canais, seja TV (TV COB), um projeto que, em função de custo elevado, não foi para a frente. Também teve o projeto da Rádio $\mathrm{COB}$, um projeto de produzir notícias para rádio, seja associado com uma emissora ou própria, também não foi para a frente. Em relação ao podcast, que é uma prática usada por várias empresas e várias entidades, não fizemos por falta de braço: a equipe do COB sempre foi muito reduzida e a nossa produção voltada para texto. Então, a produção de rádio que nós captamos não disponibilizamos no site por falta de pessoal e também da parte operacional; por pouca gente para trabalhar todas essas mídias. Em determinados períodos, em função da importância do assunto, nós captávamos esse áudio e quando as rádios pediam algumas aspas de algum entrevistado, passávamos pontualmente para essas rádios. Mas disponibilizar no site, realmente, nunca se disponibilizou áudio de cobertura de evento.
\end{abstract}

A disponibilidade do Handtalk, interface de geração de linguagem de sinais manuais voltados para surdos-mudos, Libras, e a ausência da audiodescrição foram explicadas por Motta (2017):

Chegou para nós [o Handtalk] de forma gratuita e nós percebemos que era viável colocar aquele recurso para os deficientes porque uma empresa [de software] que vendia o produto que era a tradução [de texto] para Libras fez uma oferta para uma parceria que, em um período, não teve custo para o COB. E eu acho assim: tudo que envolve custo é um pouco mais complicado de se fazer. Porque o foco do COB não é a comunicação, é preparar atletas para os Jogos. Somos entusiastas da comunicação; brigamos por orçamentos, por ferramentas, mas o foco do $\mathrm{COB}$ não é gerar conteúdo, é uma entidade de preparar atletas para os Jogos Olímpicos e, mesmo produzindo comunicação, mas não é dentro do orçamento, tem uma limitação. Todos esses projetos que não emplacam, como TV COB, Rádio COB, revista... Tudo acaba caindo na mesma questão: custos.

A maneira como os usuários atuam no ciberespaço, seja de postura passiva (o internauta que pode se expressar, mas opta por ficar em silêncio) ou de maneira inusitada (gamers que visam reconstruir a realidade por meio de simuladores em busca por metaversos alternativos ao real) torna necessária a consideração dos jornalistas que utilizam a web como meio de estabelecer contatos para agregar o maior número de fontes para a cobertura do fato esportivo. 
Esse profissional do jornalismo e da mídia não depende da emulação (HOEVEN; LOHMAN; VERDEGEM, 2017). Ao contrário, ele convive com os elementos de participação comunicativa na rede e valoriza a checagem dos fatos, a apuração de testemunhos e opiniões de caráter plural.

Após essa aproximação com o site do $\mathrm{COB}$, no capítulo a seguir discute-se a sua utilização como fonte de informação para jornalistas que realizaram a cobertura das Olimpíadas 2016 tanto in loco como remotamente.

Em texto escrito com o pesquisador Francisco Sancho, Salaverría (SALAVERRÍA; SANCHO, 2007, p.213) aborda a configuração do design dos meios cibernéticos em que a usabilidade constitui um aspecto que impacta a experiência do acesso aos sítios a partir de um conjunto linguístico aderente às ferramentas e ao modo de carregamento das páginas web:

[...] apesar dessas deficiências, os primeiros jornais digitais começaram a se familiarizar com novos conceitos no design de jornais. Termos como 'navegação', 'hipertexto' ou 'usabilidade' passaram a fazer parte da gíria profissional dos desenvolvedores de páginas da web. Até então, falar sobre designers da cibermídia teria sido, para dizer o mínimo, uma extravagância. Os jornalistas que produziram essas primeiras publicações digitais foram profissionais versáteis que logo compuseram uma página com linguagem HTML, escreveram uma reportagem ou resolveram uma pane no servidor. A figura do 'homem-orquestra' retratava fielmente o trabalho diário daqueles pioneiros.

$\mathrm{Na}$ ausência de um padrão para imitar, entende-se que os primeiros editores de mídia digital deram traços cegos constantes. Essa desorientação foi refletida em muitos aspectos. Para começar, nos domínios usados para publicar os jornais na web. Alguns desses domínios não atendem aos padrões mínimos de clareza e simplicidade mnemônica. (Tradução nossa) $^{36}$

A partir dos pressupostos levantados, faz-se necessária a consideração do objeto abordado nesta tese - o site do Comitê Olímpico do Brasil (COB) - a partir das classificações

\footnotetext{
${ }^{36}$ No original, em espanhol: "[...] a pesar de estas cortapisas, los primeros periódicos digitales comenzaron a familiarizarse con conceptos nuevos en el diseño periodístico. Términos como 'navegación', 'hipertexto' o 'usabilidad' comenzaron a formar parte del argot profesional de los desarrolladores de páginas web. Por entonces, hablar de diseñadores de cibermedios hubiera sido, por decirlo moderadamente, una extravagancia. Los periodistas que elaboraban aquellas primeras publicaciones digitales eran profesionales polivalentes que tan pronto componían una página con lenguaje HTML, como redactaban una noticia o solucionaban alguna caída del servidor. La figura del 'hombre-orquesta' retrataba fielmente el quehacer cotidiano de aquellos pioneros.

Ante la falta de un patrón que imitar, se comprende que aquellos primeros editores de medios digitales dieran constantes palos de ciego. Esa desorientación se reflejaba en múltiples aspectos. Para empezar, en los propios dominios empleados para publicar los diarios en la Web. Algunos de esos dominios no cumplían las más mínimas normas de claridad y sencillez nemotécnica".
} 
propostas e com base em informações obtidas com a visita técnica à instituição, realizada em 2017:

- Características: veículo de informação jornalística disponibilizado na web pelo $\mathrm{COB}$, com publicação de notícias dos atletas confederados, cobrindo eventos patrocinados pelas federações esportivas ou torneios locais, nacionais e internacionais, de natureza institucional ou não. Como exemplo, há publicações tanto dos Jogos Olímpicos de Inverno, Verão e Jogos Escolares da Juventude, como o Campeonato Mundial de Vôlei de Praia, o Mundial Militar de TaeKwon-Do e o Grand Slam de Judô;

- Destinação do conteúdo: o diretor de comunicação, Cláudio Motta (2017), descreve os objetivos do site:

[...] o nosso principal compromisso com essa informação é a credibilidade, é fazer chegar nesse público, que é um pouco diverso - incluímos fontes, torcedores, patrocinadores, governo [...] e, sobretudo, imprensa - uma fonte altamente confiável de informação.

A partir dessas considerações, torna-se possível afirmar que o site do COB constitui um veículo de natureza cibernética, presente também nas redes sociais (Twitter e Facebook) e com canal de vídeo no YouTube (Time Brasil). As informações publicadas têm o compromisso de ter credibilidade e servir como referência. No entanto, devido ao vínculo com o Comitê Olímpico do Brasil, trata-se de um veículo institucional. Por esse motivo, existe uma tendência a associá-lo a uma assessoria de imprensa ou agência de notícias. $\mathrm{Na}$ maior parte dos casos, tem seu público composto por fãs dos esportes e, eventualmente, por jornalistas que cobrem os eventos, confederações e patrocinadores que investem em determinada modalidade ou atleta. 


\section{A COBERTURA OLÍMPICA: CONSULTA AOS JORNALISTAS}

Este capítulo tem por finalidade verificar - junto a jornalistas que atuam nos canais de mídia do Brasil e de Portugal - a viabilidade da aplicação de conteúdos cibernéticos como fontes de informação e ferramentas de auxílio ao trabalho desses profissionais no contexto do webjornalismo (CANAVILHAS, 2006). Ao fazer a consulta aos profissionais da mídia, torna-se necessária uma aproximação com o conceito de fonte jornalística, com a finalidade de discutir o problema de pesquisa desenvolvido nesta tese: a possibilidade de utilização do site do $C O B$ como fonte para a produção de notícias. Como jornalistas, consideram-se aqui, além dos profissionais diplomados, aqueles que exerceram funções jornalísticas, como editores e repórteres.

\subsection{Fontes de informação jornalística: dos contatos ao ciberespaço}

No rol das atividades desempenhadas no preparo e produção de notícias, a consulta de fontes se destaca como um procedimento colaborativo e de aproximação com pessoas que exercem papéis no processo de tratamento dos fatos, entre os quais se destacam as testemunhas, especialistas ou mesmo suportes (livros, sites, etc.), instituições ou indivíduos que atuam como contato externo ao ambiente do repórter. O trabalho com as fontes torna-se imprescindível na maior parte das etapas de preparação do material jornalístico: pauta, apuração e produção.

O professor Manuel Pinto (2000), da Universidade do Minho (UMINHO), em Portugal, elenca as principais características das fontes no jornalismo, com destaque para as entrevistas:

Há dois caminhos essenciais para a coleta de informações: uma, em torno das informações ou dados documentais e outra é através de fontes pessoais e institucionais, mas as próprias informações institucionais, muitas vezes, são veiculadas por pessoas ou por profissionais que trabalham nessas instituições e, deste ponto de vista, digamos, não há pesquisa e contato com as fontes que não passe pelas pessoas e pela entrevista às pessoas, eu diria, quase rotineira de contato para a obtenção de informações embora essa transação entre fonte e jornalista seja bastante complexa, porque não há fontes desinteressadas. As fontes são sempre interessadas. Mas a questão não é sobre as fontes, é sobre o papel da entrevista na coleta de informação para a pesquisa jornalística. Eu creio que ela tem tanta importância para a pesquisa jornalística como para a pesquisa em 
jornalismo: ela mesma vive muito dessa técnica fundamental que é a entrevista.

A perspectiva de que as fontes contribuem com o fornecimento de versões diferentes que complementam as informações jornalísticas também tem sua abordagem teóricoconceitual discutida por Lage (2014, p.59):

Poucas matérias jornalísticas originam-se integralmente da observação direta. A maioria contém informações fornecidas por instituições ou personagens que testemunham ou participam de eventos de interesse público. São o que se chama de fontes. [...] É tarefa comum dos repórteres selecionar e questionar essas fontes, colher dados e depoimentos, situá-los em algum contexto e processá-los segundo técnicas jornalísticas.

Uma classificação de fontes de notícias proposta pelo pesquisador Aldo Antônio Schmitz (2011, p.24) também serve como ponto de apoio às entrevistas com jornalistas e sua posterior análise:

[Fonte] Primária:

Fornece diretamente "o essencial de uma matéria... fatos, versões e números", por estar próxima ou na origem da informação. Geralmente revela dados "em primeira mão", que podem ser confrontados com depoimentos de fontes secundárias.

Fonte Secundária:

Contextualiza, interpreta, analisa, comenta ou complementa a matéria jornalística, produzida a partir de uma fonte primária. Igualmente, é com quem o repórter repercute os desdobramentos de uma notícia (suíte). Também é consultada no planejamento de uma pauta [...].

A utilização de fontes disponíveis na web exige atenção porque, como não há desinteresse, o procedimento da produção de notícias (HOHENBERG, 1981) implica ponderar em relação às prioridades e, sobretudo, às demandas sociais que circunscrevem o ambiente em torno do jornalista. Esse impacto também repercute no uso da tecnologia no âmbito das fontes, sejam subjetivas ou institucionais. Machado (2003, p.43) explica como ocorre esse processo no meio cibernético:

A institucionalização de uma cultura sedimentada pela aura de um falso cosmopolitismo transforma em lugar-comum o desprezo pelas demandas do local, com a recorrência a temas vinculados a realidades distantes ou aos modismos da agenda [...]. A entrada das organizações jornalísticas brasileiras como atores representativos no mundo das redes digitais pressupõe a superação dessa matriz que desconhece a pesquisa aplicada 
como uma das etapas essenciais no processo de produção de conhecimento das sociedades contemporâneas.

Desse modo, o procedimento da pesquisa emerge como uma atividade necessária na prática jornalística, cabendo ao profissional da imprensa o estabelecimento de uma mediação (MARTÍN-BARBERO, 2010) necessária a ponto de distanciar os interesses e aproximar as informações obtidas, cujo tratamento noticioso as transformará em informação de relevância pública e social.

Ao abordar o jornalismo esportivo, a pauta e a produção da notícia, surge um conceito importante deste trabalho: a usabilidade. Nesse contexto, entende-se a expressão como a facilidade com que os jornalistas acessaram os recursos do site do $\mathrm{COB}$, desde o carregamento da página até a pertinência, qualidade e confiabilidade do sítio como fonte de informação.

\subsection{Consulta aos jornalistas}

Para esta seção, utilizou-se como método a entrevista de enfoque qualitativo (ROSA; ARNOLDI, 2016, p.17):

A entrevista é uma das técnicas de coleta de dados considerada como sendo uma forma racional de conduta do pesquisador, previamente estabelecida, para dirigir com eficácia um conteúdo sistemático de conhecimentos, de maneira mais completa possível, com o mínimo de esforço de tempo.

Como procedimento metodológico, recorre-se à análise de conteúdo a partir da concepção de Bardin (2008, p.29), ao considerar:

A ultrapassagem da incerteza: o que eu julgo ver na mensagem estará lá efetivamente contido, podendo esta "visão" muito pessoal ser partilhada por outros [...]. Por outras palavras, será a minha leitura válida e generalizável;

E o enriquecimento da leitura: sem um olhar imediato, espontâneo, já é fecundo, não poderá uma leitura atenta, aumentar a produtividade e a pertinência?

Pela descoberta de conteúdos e de estruturas que confirmam (ou infirmam) o que se procura demonstrar a propósito das mensagens, ou pelo esclarecimento de elementos de significações suscetíveis de conduzir a uma descrição de mecanismos de que a priori não detínhamos a compreensão (Itálicos da autora). 
Diante da aplicação das análises, recorre-se como procedimento ao processo de articulação das falas dos entrevistados a partir do modelo definido na tese de doutorado de Moraes Júnior (2011, p.149):

Apoiada no processo comunicativo, a enunciação parece pertinente a esta pesquisa, que tem como base a entrevista semiestruturada, em que os entrevistados foram convidados a falar sobre o tema pesquisado, retomando, em sua fala, por diversas vezes, os mesmos tópicos do assunto, desviando-se dos elementos formais da própria fala.

Medina (1988, p.61) explica as particularidades que tem uma entrevista realizada in loco, principalmente com relação à humanização na notícia:

Na grande parte de suas reportagens, as fontes são personagens anônimos, caracterizados por uma presença mais ficcional do que jornalística, ou ficam semi-identificados como tipos sociais, sem perfeita individualização. É raro o caso em que as informações chegam à identificação direta (Itálicos nossos).

Pressupondo-se a utilização do site do COB como fonte jornalística (PINTO, 2000; LAGE, 2014) na elaboração de material informativo durante as Olimpíadas de 2016, a consulta aos profissionais se baseou em duas perguntas centrais, conforme o modelo de entrevista em profundidade estruturada:

- Como foi a cobertura dos Jogos Olímpicos em 2016?

A pergunta teve a finalidade de verificar junto aos jornalistas qual foi o perfil de cobertura noticiosa. Por meio das falas daqueles que trabalham em grandes veículos e na mídia alternativa também se pretendeu verificar a abrangência da cobertura, desde as facilidades até as limitações;

- Durante os Jogos Olímpicos do Rio 2016, de que maneira o site do COB foi acessado para a obtenção de informações para notícias ou pautas? Quais recursos foram utilizados?

A pergunta, em especial, remonta às discussões apresentadas no início desta tese - jornalismo esportivo e pauta olímpica - e tem a finalidade de verificar quais ferramentas da web foram, de fato, úteis para os jornalistas durante a cobertura das Olimpíadas de 2016. 
Nesse caso específico, o foco metodológico para a descrição analítica tem base no estudo de Moraes Júnior (2011) e visa atender requerimentos da linha de pesquisa em que esta tese se encontra inserida: Estudo dos Meios e da Produção Midiática, à qual se vincula também o trabalho do referido pesquisador.

Para reforçar o caminho de análise das falas, considera-se que os jornalistas também se apropriam das ferramentas da web para realizar seu trabalho. Professor emérito da Universidad del Valle, na Colômbia, Jesús Martín-Barbero (2010, p. XXXVII) exemplifica esse desafio proposto a partir do âmbito metodológico:

Atenção, porque a armadilha consiste tanto em enganar o rosto com a máscara - a memória popular com o imaginário de massa - como acreditar que possa existir uma memória sem um imaginário desde aquele que o ancora no presente e encoraja o futuro. Necessitamos de tanta lucidez para confundi-los como para pensar as relações que hoje, aqui, fazem sua mestiçagem. (Tradução nossa) $)^{37}$

Torna-se pertinente uma ressalva quanto à forma como os jornalistas foram interrogados e como a seleção dos enunciados se desenvolveu. Pelo fato de o questionamento ocorrer com perguntas, algumas falas são mais curtas e outras, mais longas. Como o objetivo das análises não buscou levantar quem falou mais ou se expressou menos, as anotações das inferências ${ }^{38}$ procuraram verificar, sobretudo, qualitativamente, os aspectos abordados pelos jornalistas.

A análise implicou a elaboração de quadros ilustrativos referentes às perguntas, com trechos dos enunciados (à esquerda). Cada quadro traz também a respectiva descrição partir das respostas dos entrevistados, base para as inferências e a análise de conteúdo (à direita).

Os entrevistados participaram in loco ou remotamente da cobertura olímpica, atuando como repórteres ou editores de conteúdo para a mídia brasileira. Além de exercer essas funções, alguns dos colaboradores não possuem formação superior (graduação) em Comunicação Social, especialmente na habilitação em Jornalismo. São eles:

- José Ricardo Campos Leite: jornalista que, na época dos Jogos Olímpicos de 2016, atuava como editor do site UOL, em São Paulo. A entrevista ocorreu no Rio de

\footnotetext{
${ }^{37}$ No original, em espanhol: “Atención, porque la trampa consiste tanto en engañar el rostro con la máscara la memoria popular con el imaginario de masa - como creer que pueda existir una memoria sin un imaginario desde aquel que lo ancla en el presente y alienta el futuro. Necesitamos tanta lucidez para confundirlos como para pensar las relaciones que hoy, aquí, hacen su mestizaje".

${ }^{38}$ No contexto metodológico, inferir significa tecer considerações; conhecer (BARDIN, 2008).
} 
Janeiro, em 25 de abril de 2018, na sede do canal FoxSports, atual local de trabalho de Leite. A escolha do UOL se ampara na relevância que esse sítio possui como um dos mais acessados, além de aparecer como uma referência em produção de conteúdo informativo no Brasil;

- Rafael Bullara: jornalista que, na época, atuava como editor do jornal esportivo Lance! O registro da entrevista ocorreu no dia 29 de agosto de 2018, nas dependências do Shopping JK, na Vila Olímpia, em São Paulo. A conversa teve a finalidade de abordar junto a esse jornalista as atividades por ele desenvolvidas no veículo impresso durante os Jogos de 2016. A escolha do jornal Lance! considerou o tratamento dado às Olimpíadas por este meio: uma diagramação temática em que a cobertura do futebol funcionava de forma concomitante com as demais modalidades;

- Fernando Saraiva: jornalista e editor do canal por assinatura SporTV. A entrevista ocorreu no dia 08 de maio de 2018, no Rio de Janeiro, nas dependências da geradora dos canais Globosat. A entrevista buscou verificar como funcionou a cobertura das Olimpíadas em uma emissora da televisão por assinatura oficial, com posse de direitos de transmissão;

- Victor Sá Ramalho Antonio: historiador e editor do Portal do Rugby. O registro da entrevista ocorreu no dia 24 de abril de 2018, nas dependências da Faculdade de Filosofia, Letras e Ciências Humanas (FFLECH) da USP. A opção pelo Portal do Rugby se deve a duas características específicas quando da cobertura das Olimpíadas no Rio de Janeiro em 2016: a especialização na modalidade, cuja versão 7s teve partidas olímpicas e, sobretudo, ao fato de o portal aparecer com um canal especializado em uma categoria com pouca visibilidade no Brasil;

- Fábio França: jornalista que atua como editor, coordenador da equipe de esportes e apresentador da Rádio BandNews FM, emissora que compõe uma rede com programação dedicada ao jornalismo e à cobertura de eventos esportivos. A entrevista foi realizada em 02 de maio de 2018, nas dependências da emissora, em São Paulo. A escolha da rádio BandNews FM levou em consideração a transmissão de eventos competitivos por esta estação, além de contar com diversas equipes de cobertura in loco e a perspectiva de obtenção de detalhes específicos quanto aos direitos de transmissão que a emissora obteve para os Jogos; 
- Vitor Prates: radialista dedicado a plantões e cobertura eventos esportivos, além de editor do Blog do Vitor Prates. A entrevista ocorreu em 12 de setembro de 2018, nas dependências da Rádio Educativa de Piracicaba, no interior de São Paulo. A escolha se deve à sua atuação independente nos veículos de Piracicaba, como colaborador das emissoras de rádio Difusora e Educativa, do jornal Gazeta de Piracicaba e como editor do Blog do Vitor Prates;

- Geraldo Armando Cardoso Neto: jornalista e editor esportivo da EPTV (afiliada da Rede Globo na macrorregião de Ribeirão Preto, no estado de São Paulo). Registrada no dia 21 de agosto de 2018, nas dependências da emissora, a entrevista teve a finalidade de verificar aspectos da cobertura regional em um canal da televisão aberto a partir da realização de uma série temática com os atletas que residiam ou efetuavam as atividades de treinamento nas cidades de cobertura da EPTV;

- Nathália Ely Silveira: jornalista e repórter do site Travinha. A entrevista foi realizada no dia $1^{\circ}$ de setembro de 2018, nas dependências do Charrua Clube, em Porto Alegre. A participação de Silveira teve papel relevante no registro de opinião diferenciada quanto à cobertura e à divulgação da prática de esportes olímpicos e amadores. A conversa procurou evidenciar também a atuação de uma jornalista mulher em um sítio focado em noticiário esportivo, bem como as atividades desenvolvidas na cobertura olímpica no veículo;

- Marcus Von Groll: jornalista, repórter e coordenador do site Travinha ${ }^{39}$. A entrevista aconteceu no dia $1^{\circ}$ de setembro de 2018, nas dependências do Charrua Clube, em Porto Alegre. A escolha teve a finalidade de verificar as estratégias utilizadas na cobertura dos Jogos, bem como o foco de atuação em modalidades com pouca visibilidade na mídia brasileira, algumas delas do âmbito amador, sem vínculo nem reconhecimento com o alto rendimento;

- Sérgio Settani Giglio: professor do curso de Educação Física da Unicamp e editor do site Ludopédio. A entrevista ocorreu no dia 17 de setembro de 2018. A escolha desse sítio se deve ao impacto da produção de textos voltados às modalidades olímpicas em contraponto ao "esporte praticado com os pés", principal foco de atuação do veículo. Pelo fato de divulgar material com perfil acadêmico, o Ludopédio tangencia uma potencial relevância como fonte de pesquisa em trabalhos de temática esportiva.

\footnotetext{
${ }^{39} \mathrm{O}$ site Travinha foi o único com dois entrevistados, justamente para ter um caso com duas opiniões.
} 
Os depoimentos e as análises destacadas nos quadros a seguir foram incluídos a partir das datas das entrevistas, da primeira até a última.

\subsubsection{A cobertura jornalística dos Jogos Olímpicos no Rio de Janeiro em 2016}

Nesta seção, foram elencados os trechos dos depoimentos e as análises referentes à primeira questão sobre a cobertura jornalística dos Jogos Olímpicos de 2016. A discussão referente a atuação específica de cada colaborador tem o objetivo de sublinhar os diferentes âmbitos, abordagens a fim de se levantar aspectos particulares da produção de notícias referentes ao evento que contemplou diversas modalidades em meio a uma variedade de pautas desenvolvidas pelos entrevistados.

Entrevistado: José Ricardo Campos Leite, na época, editor do site UOL PRIMEIRA QUESTÃO: A COBERTURA DOS JOGOS OLÍMPICOS DE 2016

\begin{tabular}{|c|c|}
\hline ENUNCIADO & DESCRIÇÃO ANALÍTICA \\
\hline $\begin{array}{l}\text { [...] é um negócio muito difícil: no jornalista } \\
\text { que cobre uma olimpíada in loco, existe até uma } \\
\text { falsa sensação de que está conseguindo } \\
\text { acompanhar tudo e não, é pior: ele está } \\
\text { conseguindo acompanhar muito menos, porque } \\
\text { ele está em casa e está recebendo na internet } \\
\text { todas as informações e na TV, passando tudo } \\
\text { que está rolando. Quando você está mergulhado } \\
\text { em algum jogo, você tem que ficar focado } \\
\text { naquilo e ficar fazendo aquilo, olhando durante } \\
\text { o tempo todo e você perde um pouco a noção } \\
\text { do todo que está acontecendo. }\end{array}$ & $\begin{array}{l}\text { O jornalista José Ricardo Campos Leite descreve a } \\
\text { importância da cobertura in loco. Entretanto, a } \\
\text { informação das partidas que abrangem as } \\
\text { competições em todas as modalidades, ainda que } \\
\text { realizadas no mesmo dia, mostram-se excessivas e a } \\
\text { pauta olímpica deve ser focada exatamente no jogo } \\
\text { em andamento. A sensação de simultaneidade, } \\
\text { mesmo com auxílio de dispositivos digitais portáteis } \\
\text { fica comprometida quando a sensação da presença no } \\
\text { local atinge prioridade, com destaque à subjetividade } \\
\text { do repórter. }\end{array}$ \\
\hline $\begin{array}{l}\text { Você escuta falar ou lê também porque os } \\
\text { meios digitais hoje nos possibilitam nos } \\
\text { informar de tudo, mas você não vivenciou com } \\
\text { aquela experiência de ter visto. Então, sentimos } \\
\text { falta, um pouco disso, quando você cobre in } \\
\text { loco: você vive a energia daquilo que você viu, } \\
\text { mas aquilo que você não viu, você mal tem } \\
\text { tempo de ver pela TV, como a pessoa que está } \\
\text { em casa, que não está trabalhando com aquilo. } \\
\text { É uma dificuldade, você só viveu aquilo que } \\
\text { você viu que estava naquele dia. Se foi legal, } \\
\text { ótimo, agora o resto é meio que história que os } \\
\text { outros contam para você. Eu tinha até um caso } \\
\text { assim, dos nossos editores lá do UOL: ele não } \\
\text { ia para eventos, só ficava no Centro de } \\
\text { Imprensa para fechar o material, texto para o } \\
\text { dia seguinte. Ele não foi para nenhum evento e } \\
\text { o tempo todo e brincava: me sinto aqui igual ao } \\
\text { Carlos Alberto de Nóbrega, da Praça é Nossa: }\end{array}$ & $\begin{array}{l}\text { Leite menciona acontecimentos específicos que } \\
\text { marcaram sua percepção como repórter in loco e ao } \\
\text { mesmo tempo, espectador das partidas: vivência e } \\
\text { ambientação no local, com acompanhamento dos } \\
\text { espectadores da arquibancada, conversa com os } \\
\text { personagens (atletas, técnicos e árbitros) e a comitiva } \\
\text { ao redor da competição. Evidencia-se uma marca } \\
\text { importante no momentum social: na mídia } \\
\text { audiovisual ou nos simuladores digitais não se cria } \\
\text { com a mesma intensidade. } \\
\text { Em contrapartida, há os jornalistas que não fizeram } \\
\text { um acompanhamento in loco deixam de desfrutar da } \\
\text { convivência pessoal, ao acompanharem } \\
\text { exclusivamente o trabalho dos colegas em meio à } \\
\text { produção e circulação de notícias, nas dependências } \\
\text { do Centro de Imprensa. }\end{array}$ \\
\hline
\end{tabular}


não vejo nada e só vejo pessoas sentadas ao meu lado e contarem histórias do que elas viam, e eu não estou vendo nada e só acompanho histórias "puxa, hoje foi legal no basquete, o Thiago Brás do salto com vara, que história sensacional". Então, você não vê aquilo, porque o Thiago Brás até que foi uma das histórias mais sensacionais para o Brasil e eu estava jantando, comendo um lanche no hotel, escrevendo no meu notebook. E, assim, por acaso, estava perto de uma televisão. Se não estivesse, não teria nem visto esse momento ao vivo.

A partir da percepção de José Ricardo Campos Leite (2018), evidenciam-se as expectativas pessoais e profissionais durante a cobertura dos Jogos Olímpicos no Rio de Janeiro em 2016: estar em contato com a realidade no momento - local, pessoas e evento. Porém, há necessidade que os repórteres realizem o trabalho em equipe, pois a sensação de simultaneidade e bombardeio de informações dá lugar ao foco na atividade jornalística e na necessidade de manter a atenção no evento ou no recorte que se está inserido.

A remediação (BOLTER; GRUSIN, 2000) também elucida a maneira contextual da realização da cobertura esportiva em questão: necessidade de consultar outros meios de comunicação a fim de manter o repertório pessoal suficientemente atualizado para a pauta esportiva, nesse caso, como fonte. As demais notícias dos Jogos Olímpicos que ocorrem simultaneamente podem acabar por fazer parte do cotidiano do repórter in loco quando este se encontra no papel de espectador, por exemplo, da televisão.

Entrevistado: Rafael Bullara, na época, editor do jornal Lance! PRIMEIRA QUESTÃO: A COBERTURA DOS JOGOS OLÍMPICOS DE 2016

\begin{tabular}{|c|c|}
\hline ENUNCIADO & DESCRIÇÃOANALÍTICA \\
\hline $\begin{array}{l}\text { [...] Em 2016, eu fiquei em São Paulo, cuidava } \\
\text { da parte impressa do Lance!. Então, não cobri } \\
\text { os Jogos in loco, fiquei em São Paulo e aí eu } \\
\text { fazia a capa do jornal Lance! e aí, no período de } \\
\text { Olimpíadas, a gente dividia: o Lance!, como é } \\
\text { um jornal que fala muito de futebol, a gente } \\
\text { dividia com a parte olímpica: então, tínhamos } \\
\text { duas capas diárias - a primeira, uma capa de } \\
\text { futebol, com os clubes com o acompanhamento } \\
\text { normal do dia a dia - e aí, do outro lado, você } \\
\text { invertia, tinha uma outra capa: eram as páginas } \\
\text { das Olimpíadas. }\end{array}$ & $\begin{array}{l}\text { O jornalista Rafael Bullara menciona a utilização de } \\
\text { estratégias diferenciadas para a cobertura dos Jogos } \\
\text { Olímpicos. A utilização de diagramação diferenciada } \\
\text { pressupõe a existência de demandas a serem } \\
\text { atendidas pelo jornal Lance!: ainda que os principais } \\
\text { eventos esportivos realizados no Brasil tenham sido } \\
\text { paralisados em função das competições olímpicas, os } \\
\text { noticiários de futebol coexistiam com as notícias } \\
\text { olímpicas. A divisão de prioridades busca atender o } \\
\text { público que busca notícias de futebol quanto dos } \\
\text { Jogos Olímpicos. }\end{array}$ \\
\hline $\begin{array}{l}\text { Diariamente, fazíamos uma reunião como } \\
\text { pessoal que estava no Rio, com a equipe de } \\
\text { repórteres e editores que estavam nos Jogos }\end{array}$ & enciona outro asp \\
\hline
\end{tabular}


pautas e o que eles teriam de páginas para referente à publicidade, como forma de equilibrar a organizarmos o dia de eventos que eles iam publicação.

cobrir até o final do dia. Então tinha essa questão, digamos, editorial, e a questão que era mesmo pensar o jornal para tentar encaixar com todas as outras coisas e outras demandas que se tem: como a parte comercial, reserva de anúncios, coisas desse tipo que também pegam a parte impressa. Então era mais ou menos assim que funcionava: a gente pensava e aí o repórter que estava cobrindo o basquete e falava que tinha uma matéria e iria precisar de uma página, o outro falava assim: "estou cobrindo o vôlei e preciso de duas páginas" e, para isso, tentávamos equilibrar o espaço para todos terem suas matérias [publicadas].

Rafael Bullara (2018) menciona que a cobertura dos Jogos Olímpicos de 2016 pelo jornal Lance! contou com uma diagramação diferenciada. O objetivo foi atender aos leitores de notícias de futebol e dos Jogos Olímpicos. Com isso, optou-se pela reserva (gerenciamento) de espaços destinados à publicidade, bem como de notícias sobre as modalidades olímpicas, buscando dar um equilíbrio tanto na parte comercial como na área destinada às informações sobre o futebol.

Segundo o jornalista, a parte destinada aos Jogos consistia na contracapa que, ao ser invertida, se transformava na edição olímpica, com notícias referentes ao evento. A paginação, por sua vez, conduzia o leitor a informações referentes às Olimpíadas.

Entrevistado: Fernando Saraiva, editor do canal SporTV PRIMEIRA QUESTÃO: A COBERTURA DOS JOGOS OLÍMPICOS DE 2016

\begin{tabular}{|c|c|}
\hline ENUNCIADO & DESCRIÇÃO ANALÍTICA \\
\hline $\begin{array}{l}\text { Tive a oportunidade de cobrir muito futebol, } \\
\text { mas também grandes eventos mundiais de } \\
\text { outros esportes. O SporTV planejou muito essa } \\
\text { cobertura, eram mais de mil profissionais } \\
\text { envolvidos na cobertura dos Jogos Olímpicos. } \\
\text { Foi um projeto grandioso e audacioso porque o } \\
\text { SporTV tinha } 16 \text { canais. Basicamente tinham } \\
12 \text { canais para transmitir os eventos esportivos, } \\
\text { as competições, } 3 \text { canais - SporTV e SporTV } 2 \\
\text { e } 3 \text { com os eventos, chamados prime, os mais } \\
\text { importantes, e o SporTV 4, um canal de } \\
\text { jornalismo } 24 \text { horas. Eu trabalhei } \\
\text { especificamente nesse canal de jornalismo: } \\
\text { eram oito âncoras e a equipe que fazia a } \\
\text { madrugada, não sei precisar o número, mas } \\
\text { acho que âncoras durante o período vespertino, } \\
\text { de manhã e à noite, eram oito se revezando e aí } \\
\text { era um trabalho exatamente para vender os }\end{array}$ & $\begin{array}{l}\text { Fernando Saraiva destaca a importância da } \\
\text { principal modalidade, o futebol, na sua trajetória de } \\
\text { cobertura de eventos esportivos internacionais. } \\
\text { Para os Jogos do Rio de Janeiro em 2016, o canal } \\
\text { por assinatura SporTV tomou como prioridade o } \\
\text { planejamento da cobertura com vários canais, para } \\
\text { dar ao telespectador uma visão global sobre a } \\
\text { Olímpica. } \\
\text { A separação de modalidades definidas como Prime, } \\
\text { caracterizadas pela alta demanda dos espectadores } \\
\text { a partir de modalidades mais conhecidas, como } \\
\text { futebol, vôlei, basquete e tênis. } \\
\text { A atuação de Saraiva ocorreu especificamente no } \\
\text { quarto canal do SporTV, voltado especificamente } \\
\text { para o jornalismo a partir do trabalho revezado com }\end{array}$ \\
\hline
\end{tabular}


outros canais do SporTV; a gente tinha um mosaico "nesse momento o SporTV 8 está transmitindo a final da natação de determinada prova, o SporTV 12 está transmitindo Brasil e Alemanha no basquete".

$\mathrm{Eu}$ acho que o SporTV conseguiu dar a dimensão exata e recebeu muitos prêmios por isso, inclusive, teve a cobertura muito premiada.

Mas, especificamente, falando do meu dia a dia nas Olimpíadas era isso: eu entrava às duas [horas] da tarde, estava num estúdio de vidro, glass studio - que eles chamam, na avenida Abelardo Bueno, em frente ao Parque Olímpico, no último andar, com vista para todo o parque e dali o SporTV tinha um dos seus estúdios que transmitia para o canal SporTV 4. A minha rotina era: acordava, me informava do que estava acontecendo, dos eventos, chegava para trabalhar às 14 horas e saía às 22 horas. $\mathrm{E}$ aí era isso: noticiando e girando - muita agilidade - eram dois âncoras e mais dois comentaristas. O SporTV teve 200 comentaristas de todas as modalidades, que participavam das transmissões e também do SporTV 4. Então, falamos de um projeto muito grande e o meu trabalho era ser um âncora do SporTV 4 para dar ao telespectador uma visão global de tudo que estava acontecendo durante as Olimpíadas. oito apresentadores, além da equipe que atuava nas madrugadas. Um dos destaques foi o mosaico: um giro entre os 16 canais com destaque às transmissões ao vivo das competições dentre as 40 modalidades durante os Jogos Olímpicos. Ao dar mais espaço às transmissões a partir da abrangência dos eventos, Saraiva destacou o reconhecimento externo com a entrega de prêmios à emissora.

Para uma ampla cobertura, há necessidade de dedicação dos profissionais, bem como uma infraestrutura que possibilite maior agilidade da cobertura devido às diferentes competições.

A divisão dos trabalhos entre as equipes resultou em rotinas específicas para cada repórter do SporTV. O trabalho de Saraiva, voltado ao canal 4, de perfil jornalístico, imprimia um cotidiano dividido entre a pesquisa dos eventos e acontecimentos no período da manhã e a partir da tarde até as 22 horas.

O jornalista também salienta sua atuação como apresentador e editor no SporTV 4 e do trabalho de 200 comentaristas com a finalidade de cada um atuar em cada a partir das especialidades.

Fernando Saraiva (2018) explica que a cobertura do canal por assinatura SporTV ocorreu em virtude de um planejamento da atuação dos três canais da rede com mais outros 13. A distribuição dos esportes com mais demanda e familiaridade dos espectadores eventos Prime - a partir dos três canais principais, estendendo-se a outros 12 canais transmitidos em tempo real. O último canal, o SporTV 4, teve a temática e o enfoque do jornalismo a partir de telejornais, mesas de debate e da participação de 200 comentaristas especializados em uma das modalidades das Olimpíadas.

Além do planejamento, o canal jornalístico contou com a movimentação de oito apresentadores que se revezavam durante manhã, tarde e noite, além da equipe que atuava durante a madrugada. Saraiva (2018) destaca a finalidade de contar com três canais para eventos Prime, 12 para a transmissão dos jogos e um dedicado ao jornalismo durante os Jogos Olímpicos: passar agilidade, girar entre os eventos e dar aos espectadores uma visão global dos acontecimentos. 
Entrevistado: Victor Sá Ramalho Antonio, editor do Portal do Rugby

PRIMEIRA QUESTÃO: A COBERTURA DOS JOGOS OLÍMPICOS DE 2016.

\begin{tabular}{|c|c|}
\hline ENUNCIADO & DESCRIÇÃO ANALÍTICA \\
\hline $\begin{array}{l}\text { O trabalho in loco no Rio de Janeiro foi mais } \\
\text { simples que parece, porque nos Jogos } \\
\text { Olímpicos, o importante foi buscar entrevistas, } \\
\text { sentir o clima: fizemos vídeos lá no evento etc. } \\
\text { Mas a cobertura dos jogos em si, por exemplo, } \\
\text { a parte mais bruta, de fazer [as seções] Nação } \\
\text { ao Vivo por [transmissão em] rede social, } \\
\text { Placar ao Vivo e aquela coisa toda e escrever os } \\
\text { relatos dos Jogos, analisar as partidas etc. - são } \\
\text { coisas que, inclusive, acabei fazendo à } \\
\text { distância. Mandamos repórteres para fazer a } \\
\text { cobertura in loco porque o que importava era se } \\
\text { relacionar com os protagonistas, falar com os } \\
\text { atletas, com os torcedores e sentir o clima do } \\
\text { ambiente local. }\end{array}$ & $\begin{array}{l}\text { Victor Sá Ramalho Antonio expõe algumas } \\
\text { particularidades da sua atuação durante os Jogos } \\
\text { Olímpicos a partir da divisão do trabalho dos } \\
\text { jornalistas do Portal do Rugby: cobertura in loco e } \\
\text { a análise das partidas de rugby em dois programas } \\
\text { específicos (Nação Ao Vivo, por rede social e } \\
\text { Placar Ao Vivo, pelo Portal do Rugby). } \\
\text { Para o trabalho nos locais dos eventos, a equipe } \\
\text { tinha como prioridade fazer entrevistas e pequenos } \\
\text { boletins para passar aos usuários do portal o } \\
\text { ambiente dos atletas, torcidas e pessoas de nos } \\
\text { estádios. No caso das análises das partidas, Antonio } \\
\text { realizou esse trabalho à distância. }\end{array}$ \\
\hline $\begin{array}{l}\text { Estar lá é importante para se relacionar com os } \\
\text { protagonistas, com os jogadores e coletar essas } \\
\text { histórias: é mais uma busca por outras histórias } \\
\text { paralelas do que propriamente a cobertura dos } \\
\text { Jogos em si. São coisas diferentes que fomos } \\
\text { aprendendo com o tempo: produzimos mais } \\
\text { sobre o Jogo fora e dentro, produzimos mais } \\
\text { sobre o entorno do Jogo, sobre aquilo que gira } \\
\text { ao redor do evento. A gente acaba dividindo } \\
\text { bastante isso na nossa cobertura. O Portal do } \\
\text { Rugby foi sempre muito autônomo em sua } \\
\text { produção de material, inclusive, de repente ele } \\
\text { até ajudou a própria Confederação Brasileira de } \\
\text { Rugby. Já recebi perguntas de muitos } \\
\text { jornalistas de muitos sites grandes e veículos de } \\
\text { imprensa importantes, porque ele acaba sendo a } \\
\text { fonte para muita gente. }\end{array}$ & $\begin{array}{l}\text { Antonio exemplifica as prioridades dos enfoques } \\
\text { das equipes de cobertura in loco e da produção de } \\
\text { análises sobre as partidas de rugby: enquanto os } \\
\text { repórteres buscam histórias paralelas à competição, } \\
\text { a análise requer um enfoque concentrado no jogo. } \\
\text { Por esse motivo, quando se reúnem os materiais, o } \\
\text { trabalho externo se encarrega de apresentar os fatos } \\
\text { relacionados ao entorno da competição. } \\
\text { O jornalista também enfatiza a autonomia do Portal } \\
\text { do Rugby na produção de material cujo conteúdo } \\
\text { também ajuda a Confederação Brasileira de Rugby. } \\
\text { O contato com jornalistas que atuam em grandes } \\
\text { veículos de comunicação reforça a ideia de que as } \\
\text { informações publicadas servem como fonte para } \\
\text { esses profissionais de imprensa. }\end{array}$ \\
\hline
\end{tabular}

Victor Sá Ramalho Antonio (2018) aborda a cobertura dos Jogos Olímpicos destacando a divisão de tarefas entre as equipes. $\mathrm{O}$ grupo encarregado da cobertura in loco tinha como objetivo registrar as informações do entorno do jogo: histórias de atletas, treinadores e espectadores. A equipe responsável pelas análises, entre eles o próprio entrevistado, precisava contar apenas com dados referentes ao âmbito da partida, como as estatísticas.

Ao mencionar que "aprendeu com o tempo e produz mais", Antonio (2018) tem em mente a otimização do tempo de produção viabilizada por essa divisão de atribuições das equipes. 
Entrevistado: Fábio França, editor da Rádio BandNews FM

PRIMEIRA QUESTÃO: A COBERTURA DOS JOGOS OLÍMPICOS DE 2016

\begin{tabular}{|c|c|}
\hline ENUNCIADO & DESCRIÇÃO ANALÍTICA \\
\hline $\begin{array}{l}\text { Foi uma experiência incrível. Fui para o Rio de } \\
\text { Janeiro talvez dez dias antes do início dos Jogos } \\
\text { e voltei quatro dias depois. A cobertura foi } \\
\text { intensa do Grupo Bandeirantes de } \\
\text { Comunicação, fizemos um pool das rádios do } \\
\text { grupo: Bandnews, Rádio Bandeirantes e, na } \\
\text { época a Bradesco Esportes FM. Enfim, todo } \\
\text { mundo trabalhando em conjunto, foram muitos } \\
\text { profissionais para o Rio de Janeiro - a gente } \\
\text { montou a nossa base e todo mundo morou lá por } \\
\text { um mês - também contando com a participação } \\
\text { essencial da equipe da Bandnews do Rio de } \\
\text { Janeiro, que é uma rádio fortíssima lá. }\end{array}$ & $\begin{array}{l}\text { Fábio França enaltece a preparação e ambientação } \\
\text { no local: chegada em dez dias antes do início das } \\
\text { Olimpíadas e quatro dias depois; além da } \\
\text { integração das equipes das emissoras de rádio do } \\
\text { Grupo Bandeirantes, com uma base montada } \\
\text { próximo ao Complexo Olímpico no Rio de Janeiro. } \\
\text { A emissora afiliada da rede BandNews, do Rio de } \\
\text { Janeiro, também ajudou na cobertura com a } \\
\text { participação de profissionais no trabalho da base } \\
\text { instalada perto dos locais dos eventos. }\end{array}$ \\
\hline $\begin{array}{l}\text { Foi um trabalho incansável: acordávamos às } \\
\text { sete horas da manhã, começava a trabalhar e } \\
\text { terminava às dez da noite. O grupo realmente } \\
\text { fez um grande trabalho, uma cobertura muito } \\
\text { grande e eu participei da cobertura de vários } \\
\text { eventos, de vários esportes, mas sobretudo o } \\
\text { vôlei e foi muito legal, porque o vôlei não é algo } \\
\text { com que a gente lida aqui no dia a dia aqui na } \\
\text { rádio: fazemos muito mais futebol, Fórmula } 1 \mathrm{e} \\
\text { tal, mas vôlei - para o rádio também é um pouco } \\
\text { diferente e fazer foi muito bacana. }\end{array}$ & $\begin{array}{l}\text { O jornalista destaca a dedicação dos funcionários } \\
\text { das equipes ao trabalharem várias horas por dia. } \\
\text { O foco de atuação de França estive em vários } \\
\text { eventos de modalidades diferentes, entre as quais, a } \\
\text { experiência em cobrir as partidas de vôlei mostrou- } \\
\text { se desafiadora e recompensadora, devido ao pouco } \\
\text { contato com o esporte em comparação com as } \\
\text { competições de futebol e Fórmula } 1 \text {, considerada } \\
\text { um pouco diferente. }\end{array}$ \\
\hline
\end{tabular}

Fábio França (2018) destaca os seguintes aspectos relacionados ao seu trabalho: ambientação na cidade (ao chegar dez dias antes dos Jogos e lá residir até quatro dias após o encerramento do evento), integração e trabalho unificado das equipes das rádios pertencentes ao Grupo Bandeirantes (que montou uma base próxima ao Complexo Olímpico do Rio de Janeiro) e participação da equipe de jornalismo esportivo da rádio BandNews (afiliada da rede que colaborou com os profissionais que trabalhavam naquela agência).

Vale destacar, nas palavras do jornalista, o êxito da sua experiência e da produção em equipe durante o evento, que ele credita como "incansável”: "o grupo realmente fez um grande trabalho".

Entrevistado: Vitor Prates, plantonista esportivo e editor do Blog do Vitor Prates PRIMEIRA QUESTÃO: A COBERTURA DOS JOGOS OLÍMPICOS DE 2016

\begin{tabular}{|l|l|}
\hline ENUNCIADO & \multicolumn{1}{|c|}{ DESCRIÇÃO ANALÍTICA } \\
\hline Foi interessante fazer a cobertura porque era um & Vitor Prates descreve as atividades de cobertura dos \\
evento realizado no Rio de Janeiro e a gente & Jogos Olímpicos de 2016 em meio aos oito anos de \\
sabe das dificuldades de se ter informações com & existência de seu blog. Quanto às dificuldades, \\
os Jogos, às vezes, à noite e pelo site que eu & como no horário noturno aparecem poucas opções \\
tenho, Blog do Vitor Prates, há mais de oito & de fontes de notícias. Entre as recorridas figuram os \\
anos. Tentamos trazer para o leitor uma forma & sites UOL, Globo, Terra e o próprio sítio do COB. \\
mais detalhada: medalhas, conquistas e fazer & \\
\hline
\end{tabular}


mais referência ao Brasil que estava disputando em casa [...] a gente tinha algumas opções de sites como UOL, Globo, Terra e o próprio sítio do COB.
As notícias publicadas tiveram o objetivo de trazer aos usuários as notícias dos medalhistas e das provas, com referência aos atletas do Brasil que competiam em casa.

\section{O plantonista esportivo e weblogger Vitor Prates (2018) destaca o foco na produção} de notícias de competições e as dificuldades na obtenção de informação sobre os eventos, principalmente no período noturno. Prates (2018) também aborda a pouca disponibilidade de fontes e, entre as que publicaram conteúdo, destaca os sites UOL, Globo, Terra e COB.

Para ele, uma característica particular da cobertura foi a produção e publicação de notícias com os medalhistas e os resultados das provas com referência aos atletas brasileiros que competiam no próprio País. Outro objetivo do blogger era não deixar de publicar notícias, independentemente do período que as partidas ocorressem.

Entrevistado: Geraldo Armando Cardoso Neto, repórter e apresentador da EPTV (afiliada Rede Globo de Ribeirão Preto) PRIMEIRA QUESTÃO: A COBERTURA DOS JOGOS OLÍMPICOS DE 2016

\begin{tabular}{|l|l|}
\hline \multicolumn{1}{|c|}{ ENUNCIADO } & \multicolumn{1}{|c|}{ DESCRIÇÃO ANALÍTICA } \\
\hline $\begin{array}{l}\text { A nossa área de cobertura, nossa região, sempre } \\
\text { foi muito formadora de bons atletas em várias } \\
\text { modalidades: futebol, atletismo... Então, o que }\end{array}$ & $\begin{array}{l}\text { Geraldo Armando Cardoso Neto exemplifica a } \\
\text { necessidade do enfoque regional citando o fato de } \\
\text { que os bons atletas de várias modalidades vêm da }\end{array}$ \\
$\begin{array}{l}\text { Janeiro, uma Olimpíada brasileira, decidimos } \\
\text { regionalizar o nosso assunto, mostrar realmente } \\
\text { os atletas da nossa região que iriam participar } \\
\text { ou que já participaram de uma edição olímpica. }\end{array}$ & $\begin{array}{l}\text { escolhidos cerca de 15 esportistas que lá se } \\
\text { originaram ou que lá residiam para participar de } \\
\text { reportagens sobre os Jogos Olímpicos de 2016, cuja } \\
\text { abordagem referia como estes começaram no }\end{array}$ \\
$\begin{array}{l}\text { Então, a minha parte da atuação foi justamente } \\
\text { de pegar os atletas da nossa região que } \\
\text { participariam das Olimpíadas do Rio 2016. Eu } \\
\text { não vou me recordar dos nomes, que foram } \\
\text { muitos: foram mais de 15 atletas sobre quem fiz } \\
\text { reportagens, contando a história de como } \\
\text { começaram no esporte. }\end{array}$ & \\
\hline $\begin{array}{l}\text { Mas teve um fato que me marcou muito: foi um } \\
\text { rapaz do [ciclismo] BMX... Ele é mineiro e e } \\
\text { morou, estava morando na região de Paulínia, } \\
\text { porque lá tem uma pista muito grande de BMX } \\
\text { justamente para treinar a modalidade. Agora } \\
\text { não consigo me recordar o nome dele. Mas foi } \\
\text { uma matéria super legal porque eu não conhecia } \\
\text { nada do esporte, da bicicleta e foi uma super } \\
\text { novidade. }\end{array}$ & $\begin{array}{l}\text { O jornalista, ao mencionar um caso específico de } \\
\text { um ciclista olímpico que treinava em Campinas, }\end{array}$ \\
$\begin{array}{l}\text { E a Olimpíada, é muito fascinante, mesmo a a importância da reportagem como uma } \\
\text { gente não estando lá, no Rio de Janeiro, porque }\end{array}$ \\
$\begin{array}{l}\text { oocê sente o clima olímpico, você sente pelos } \\
\text { treinamentos, da preparação das pessoas, como } \\
\text { elas realmente tem aquele objetivo e aí entra } \\
\text { uma questão muito [intrínseca] do patriotismo. }\end{array}$ & $\begin{array}{l}\text { A série de reportagens realizada por Cardoso Neto } \\
\text { contribuiu para que fossem percebidas maneiras de } \\
\text { manifestação de patriotismo a partir do esporte. } \\
\text { Esse entendimento ocorreu tanto pela parte dos } \\
\text { praticantes individuais como das modalidades } \\
\text { coletivas, em equipe. }\end{array}$ \\
\hline
\end{tabular}


Então, o atleta olímpico (na minha visão) muitas vezes está focado, claro que a conquista pessoal também é importante, mas ele está mais focado em poder representar o País e falar assim: eu conquistei essa medalha pelo Brasil ou pelo atleta X. Então, o que ficou marcado muito para mim, foi essa questão do patriotismo, principalmente nos esportes individuais. $\mathrm{O}$ atleta, claro que ele pensa nele, mas ele vê muito o lado patriota, da nação. Então, de todos que eu perguntei em todas as entrevistas, muitos falaram assim: o meu sonho é colocar a mão no meu peito e ouvir o Hino Nacional; e isso, acho que me marcou bastante, esse patriotismo dos atletas com relação ao esporte, a Olimpíada...
Os principais símbolos de manifestação patriótica foram: atleta nascido no Brasil, cidadão brasileiro e representante da delegação brasileira e de cidadãos brasileiros; colocar a mão no peito durante a execução do Hino Nacional brasileiro.

Para o jornalista Geraldo Armando Cardoso Neto (2018), que atua na região de Ribeirão Preto, a cobertura dos Jogos contou com destaque regional. Foram escolhidos cerca de quinze esportistas nascidos ou residentes na região para participar de reportagens sobre os integrantes dos Jogos Olímpicos de 2016, cuja abordagem destacava como eles começaram no esporte.

Ao mencionar um caso específico de um ciclista olímpico que treinava em Campinas, Cardoso Neto (2018) destaca a importância da reportagem como uma oportunidade para aprender sobre o ciclismo BMX. Na série, ele destaca que também foram percebidos elementos de manifestação de patriotismo a partir do esporte, tanto por parte dos praticantes das modalidades individuais como coletivas.

Entrevistada: Nathália Ely Silveira, repórter do site Travinha PRIMEIRA QUESTÃO: A COBERTURA DOS JOGOS OLÍMPICOS DE 2016

\begin{tabular}{|c|c|}
\hline ENUNCIADO & DESCRIÇÃO ANALÍTICA \\
\hline $\begin{array}{l}\text { Como a gente estava aqui, no Rio Grande do Sul } \\
\text { [Porto Alegre] e não pôde ir ao Rio de Janeiro. } \\
\text { Somos um veículo pequeno, então, } \\
\text { acompanhamos muito o que víamos pela } \\
\text { televisão, como tenho mais tempo, trabalho no } \\
\text { site Travinha em casa e então, assistia direto } \\
\text { a[os canais de] televisão e também muito pelos } \\
\text { releases que recebíamos do Rio de Janeiro } \\
2016 \text {, da organização [do evento]: me inscrevi } \\
\text { para receber os boletins, apesar de não sermos } \\
\text { credenciados, mas a gente recebia esses releases } \\
\text { e pelo próprio site do Rio 2016, da própria } \\
\text { Olimpíada. Então, a gente se abastecia com } \\
\text { base nisso [material]. }\end{array}$ & $\begin{array}{l}\text { Nathália Ely Siqueira aborda o fato de não ter feito } \\
\text { a cobertura in loco. A televisão figurava como a } \\
\text { principal forma de acompanhar os eventos dos } \\
\text { Jogos Olímpicos, além dos releases do COB. A } \\
\text { jornalista havia se inscrito para o recebimento desse } \\
\text { material e, pelo fato de não ter credenciamento, } \\
\text { essa fonte passou a ter mais importância. }\end{array}$ \\
\hline $\begin{array}{l}\text { A gente fez muitos textos e o [site] Travinha } \\
\text { estava numa outra fase: copiávamos e } \\
\text { colávamos muitas notícias e não nos }\end{array}$ & $\begin{array}{l}\text { O trabalho de produção de textos noticiosos no site } \\
\text { Travinha ocorria com mais simplicidade a partir } \\
\text { dos textos provenientes das fontes. Nessa época, }\end{array}$ \\
\hline
\end{tabular}




\begin{tabular}{|c|c|}
\hline $\begin{array}{l}\text { dedicávamos muito a isso e nos preocupávamos } \\
\text { mais em fazer os vídeos [...] fazemos as } \\
\text { notícias, vídeos e redes sociais. Então, usamos } \\
\text { muito as informações para fazer também uma } \\
\text { coisa diferenciada dentro do que podia ser feito } \\
\text { como dentro de um site pequeno e até caseiro, } \\
\text { hoje já está diferente. Fizemos um quadro no } \\
\text { YouTube, o Plantão Olímpico Rio 2016, que } \\
\text { contávamos as curiosidades percebidas nas } \\
\text { Olimpíadas, da nossa vivência com o esporte e } \\
\text { o que achávamos que seria legal destacar e } \\
\text { contar da nossa maneira [...] contando o que } \\
\text { tinha visto e o que achava de destaque das } \\
\text { Olimpíadas - um fato curioso, um destaque, } \\
\text { alguma coisa assim. }\end{array}$ & $\begin{array}{l}\text { havia maior preocupação em fazer vídeos e a } \\
\text { publicação de material em redes sociais. } \\
\text { O programa de vídeo temático, Plantão Olímpico, } \\
\text { no YouTube contava com informações sobre as } \\
\text { curiosidades sobre as competições. }\end{array}$ \\
\hline
\end{tabular}

A jornalista Nathália Ely Silveira (2018) menciona a impossibilidade da cobertura in loco por um veículo pequeno, pelo fato de não ter credenciamento. $\mathrm{O}$ trabalho de produção de textos noticiosos no site Travinha ocorria com mais simplicidade, na grande parte dos casos a partir de textos provenientes de fontes que mandavam releases.

A profissional relembra que, na época, havia maior preocupação em fazer vídeos e disponibilizar a publicação do material nas redes sociais. Entre o material referido por ela, há o programa de vídeo temático Plantão Olímpico, no YouTube, com informações e fatos curiosos sobre os eventos.

Entrevistado: Marcus Von Groll, coordenador do site Travinha PRIMEIRA QUESTÃO: A COBERTURA DOS JOGOS OLÍMPICOS DE 2016

\begin{tabular}{|c|c|}
\hline ENUNCIADO & DESCRIÇÃO ANALÍTICA \\
\hline $\begin{array}{l}\text { A cobertura dos Jogos Olímpicos, na verdade, } \\
\text { quem mais fez foi a Nathália [Ely Silveira]. Eu } \\
\text { procurei fazer mais a parte dos vídeos em si. } \\
\text { Naquela época, ainda estávamos buscando a } \\
\text { identidade do site. A gente garimpava um } \\
\text { pouquinho em cada local, ou seja, fazia um } \\
\text { pouco de vídeo de Olimpíadas, tentava depois } \\
\text { fazer alguns uns outros quadros e as notícias } \\
\text { que a gente colocava, a cobertura, na verdade, } \\
\text { foi com a intenção de oferecer num único canal, } \\
\text { além do Comitê Olímpico [do Brasil], também } \\
\text { que tivessem sobre outras modalidades } \\
\text { esportivas. Mas naquela época, a gente pegava } \\
\text { o release da assessoria de imprensa deles } \\
\text { [COB], dava os créditos e postava no Travinha. } \\
\text { Não tinha produção própria de notícia. }\end{array}$ & $\begin{array}{l}\text { Marcus Von Groll aborda a divisão de trabalhos na } \\
\text { época da cobertura dos Jogos Olímpicos: enquanto } \\
\text { ele, como coordenador buscava implementar uma } \\
\text { identidade no site Travinha, a jornalista Nathália } \\
\text { Ely Silveira ficava encarregada de redigir o texto } \\
\text { das notícias olímpicas. Enquanto isso, o jornalista } \\
\text { se encarregava da produção de vídeos com notícias } \\
\text { e comentários para o site com outras modalidades } \\
\text { esportivas. } \\
\text { A maior parte do conteúdo das fontes chegava por } \\
\text { meio releases do Comitê Olímpico do Brasil. }\end{array}$ \\
\hline $\begin{array}{l}\text { [...] basicamente a cobertura das Olimpíadas foi } \\
\text { essa, com alguns vídeos que fizemos, de } \\
\text { curiosidades e também comentários em cima do } \\
\text { lance. Não foi um grande sucesso, até por essa } \\
\text { falta de identidade, na época. Havia alguns }\end{array}$ & $\begin{array}{l}\text { Groll atribui a visibilidade modesta do Travinha à } \\
\text { falta de identidade: o projeto do site ainda não } \\
\text { contemplava uma abordagem mais ampla da } \\
\text { publicação de notícias esportivas. Por esse motivo, } \\
\text { jornalista considerou que a cobertura dos Jogos em }\end{array}$ \\
\hline
\end{tabular}


vídeos, mas quem eram nós na época para estar opinando sobre tal atleta? Mas a gente vai experimentando; essa que foi a questão e a cobertura das Olimpíadas foi um desses experimentos. Também fizemos algumas matérias próprias, de vídeos com os gaúchos que foram e participaram dos Jogos Olímpicos.
2016 consistiu num experimento. Um detalhe, em particular, remonta a um movimento empreendido pela equipe para a produção de conteúdo próprio: os vídeos gravados com os atletas gaúchos que participaram das Olimpíadas em 2016.

Para Marcus Von Groll (2018), um fator influiu na cobertura realizada por ele para o site Travinha: a falta de um projeto que conferisse ao veículo uma identidade. Em decorrência disso, havia pouca produção própria e matérias com dados que provinham exclusivamente de releases enviados pelo COB. Em contrapartida, ele destaca os vídeos com comentários e a cobertura com atletas gaúchos que participaram das competições no Rio.

Diante da pouca quantidade de material próprio, Groll (2018) considera a fase de cobertura do site Travinha que coincide com os Jogos um experimento antes de surgir um projeto que proporcionasse o seu crescimento como um canal dedicado a modalidades esportivas.

Entrevistado: Sérgio Settani Giglio, editor do site Ludopédio PRIMEIRA QUESTÃO: A COBERTURA DOS JOGOS OLÍMPICOS DE 2016

\begin{tabular}{|c|c|}
\hline ENUNCIADO & DESCRIÇÃO ANALÍTICA \\
\hline $\begin{array}{l}\text { Pensando na proposta do Ludopédio, que é um } \\
\text { site acadêmico sobre futebol - e esse é o nosso } \\
\text { grande foco - mas, a partir dos Jogos Olímpicos } \\
\text { de } 2016 \text {, temos uma ideia de pensar não só a } \\
\text { questão do futebol, mas abrir um espaço para } \\
\text { outras possibilidades. Depois dessa edição, } \\
\text { acabamos tendo colunistas que vão tratar do } \\
\text { esporte de modo geral, sem ser especificamente } \\
\text { sobre o futebol. Esse foi um resultado desse } \\
\text { megaevento. }\end{array}$ & $\begin{array}{l}\text { O professor Sérgio Giglio aborda o objetivo do site } \\
\text { Ludopédio de reunir conhecimento acadêmico } \\
\text { sobre o futebol. A partir da realização dos Jogos } \\
\text { Olímpicos, constatou-se uma necessidade de abrir } \\
\text { espaço para outras possibilidades, como contar com } \\
\text { colunistas que tratariam do esporte de modo geral, } \\
\text { a partir do exemplo das modalidades no } \\
\text { megaevento no Rio de Janeiro em } 2016 \text {. }\end{array}$ \\
\hline $\begin{array}{l}\text { Olhando para a questão do site durante esse } \\
\text { período, sempre que tem algum evento muito } \\
\text { significativo no mundo do esporte, tentamos } \\
\text { mudar a nossa programação para dialogar com } \\
\text { o evento. Então, na biblioteca digital, que } \\
\text { colocamos as referências, passamos materiais } \\
\text { que estavam voltados aos Jogos Olímpicos, } \\
\text { então divulgar livros, buscar fotos para a nossa } \\
\text { seção de Futebol Arte que dialogassem com a } \\
\text { questão do futebol olímpico e de outras } \\
\text { dimensões do próprio megaevento. }\end{array}$ & $\begin{array}{l}\text { O período das Olimpíadas também proporcionou } \\
\text { que a temática do Ludopédio fosse ampliada e, a } \\
\text { partir da especialidade temática do futebol, houve } \\
\text { tentativas de fazer com que o conteúdo publicado } \\
\text { viesse a dialogar com a questão dos esportes } \\
\text { olímpicos. Um dos exemplos consistiu em } \\
\text { aproximar da seção Futebol Arte com o futebol } \\
\text { olímpico e de outras dimensões do megaevento. }\end{array}$ \\
\hline
\end{tabular}

Para Sérgio Settani Giglio (2018), os Jogos Olímpicos proporcionaram abertura de espaço e novas possibilidades para o Ludopédio, como a colaboração de colunistas que 
trataram dos esportes de modo geral, a partir do exemplo das competições nas modalidades dos Jogos do Rio de Janeiro em 2016.

A temática do Ludopédio foi ampliada e houve importantes tentativas de diálogo com conteúdo publicado sobre a questão dos esportes olímpicos. Giglio (2018) exemplifica uma proximidade da seção Futebol Arte com o tema 'futebol olímpico', além das outras dimensões do megaevento.

\subsubsection{A utilização do site do COB como fonte de informação}

Nesta seção, foram elencadas as descrições referentes à segunda questão sobre as fontes jornalísticas provenientes da web e, sobretudo, da consulta ao site do Comitê Olímpico do Brasil durante a cobertura dos Jogos Olímpicos de 2016. Os quadros abaixo seguem o mesmo modelo e ordem do subitem anterior.

Entrevistado: José Ricardo Campos Leite, na época, editor do $U O L$ SEGUNDA QUESTÃO: UTILIZOU ALGUM CONTEÚDO DO SITE DO COB? QUAL FOI O CONTEÚDO UTILIZADO?

\begin{tabular}{|c|c|}
\hline UTILIZOU O SITE DO COB? & $\begin{array}{l}\text { SIM } \\
\text { Esporadicamente: agenda de eventos, entrevista de } \\
\text { atleta brasileiro após ganhar uma medalha (eles } \\
\text { organizavam esse tipo de ação, disponibilizavam } \\
\text { no site e disparavam nas redes sociais também). }\end{array}$ \\
\hline ENUNCIADO & DESCRIÇÃO ANALÍTICA \\
\hline $\begin{array}{l}\text { Os Comitês Olímpicos costumam ter uma } \\
\text { demanda de notícias, um volume de notícias e } \\
\text { de informações maiores durante os Jogos } \\
\text { Olímpicos, quando estão acontecendo muitos } \\
\text { eventos e os atletas do Brasil estão lá. Então, a } \\
\text { cobertura deles fica quase fulltime, o tempo } \\
\text { todo, como uma agência de notícias disparando } \\
\text { informações. [...] como eles tinham enviados } \\
\text { em todos os lugares e os veículos de imprensa } \\
\text { às vezes não conseguiam estar em todos os } \\
\text { lugares, porque são centenas de atletas no } \\
\text { mesmo dia, às vezes, em alguma competição } \\
\text { em que os veículos de imprensa não } \\
\text { conseguiam ter enviados, o material deles é } \\
\text { interessante. Vamos supor: não conseguimos } \\
\text { mandar alguém para a canoagem e nela, o atleta } \\
\text { do Brasil avançou e lá tem uma pessoa do COB } \\
\text { entrevistando ele e eles colocam lá no site e a } \\
\text { gente usava essas informacões. }\end{array}$ & $\begin{array}{l}\text { Leite, a produção de notícias pelos Comitês } \\
\text { Olímpicos justifica um grande volume de } \\
\text { informações durante os Jogos Olímpicos pelo fato } \\
\text { de ocorrerem muitos eventos com a participação de } \\
\text { atletas confederados. O jornalista compara essa } \\
\text { produção a uma agência de notícias, por contarem } \\
\text { com muitos correspondentes em todos os lugares. } \\
\text { Entretanto, as equipes dos veículos de imprensa do } \\
\text { Brasil não conseguiam estar presente, dado o } \\
\text { número de provas e atletas no mesmo dia. No caso } \\
\text { desses veículos, o material do Comitê Olímpico do } \\
\text { Brasil passa a ganhar relevância quando não há } \\
\text { jornalistas que acompanharam determinada prova e } \\
\text { um atleta da delegação brasileira avanço na } \\
\text { competição e um repórter do COB fez uma } \\
\text { entrevista que acaba por servir de base na produção } \\
\text { de notícias }\end{array}$ \\
\hline
\end{tabular}

Leite (2018) destaca a utilização do site do COB em ações que envolveram entrevistas com atletas, principalmente os que ganharam medalha no evento, com publicação 
nesse sítio com notificação em redes sociais. O jornalista também menciona a disposição com que os colaboradores do COB estiveram a postos em quase todos os locais de prova.

Com uma equipe de correspondentes distribuída estrategicamente, a probabilidade de que o Comitê produzisse entrevistas com os esportistas que competiam em modalidades em que não havia jornalistas dos veículos de comunicação favorecia que o UOL utilizasse as informações da página do COB.

Entrevistado: Rafael Bullara, na época, editor do jornal Lance! SEGUNDA QUESTÃO: UTILIZOU ALGUM CONTEÚDO DO SITE DO COB? QUAL FOI O CONTEÚDO UTILIZADO?

\begin{tabular}{|c|c|}
\hline UTILIZOU O SITE DO COB? & $\begin{array}{l}\text { SIM } \\
\text { Pouco: informações de atletas passadas pela equipe } \\
\text { de redação para repórteres in loco }\end{array}$ \\
\hline ENUNCIADO & DESCRIÇÃO ANALÍTICA \\
\hline $\begin{array}{l}\text { Eu usei muito pouco, era mais para ver coisas } \\
\text { assim: quando acontecia alguma curiosidade } \\
\text { sobre algum atleta dos Jogos, que se destacou e } \\
\text { não esperávamos e você vai lá [ao site do COB] } \\
\text { para buscar informação sobre ele. Quem } \\
\text { utilizava mais essa informação, obviamente, } \\
\text { eram as pessoas da equipe que estavam in loco } \\
\text { cobrindo os Jogos e o que eu posso falar que } \\
\text { ajudou nessa questão da web, que eu utilizei } \\
\text { particularmente foi assim: como você tem uma } \\
\text { equipe que, durante as Olimpíadas, está focada } \\
\text { em determinados eventos, ela não consegue } \\
\text { acompanhar [algo] para ver o que está } \\
\text { acontecendo. }\end{array}$ & $\begin{array}{l}\text { Bullara explica porque utilizou pouco o conteúdo } \\
\text { do site do COB como fonte, como no caso de atletas } \\
\text { que não apareciam como favoritos e, no entanto, se } \\
\text { destacavam em alguma competição. } \\
\text { Bullara também menciona a importância do } \\
\text { trabalho dos jornalistas da redação para auxiliar os } \\
\text { correspondentes in loco devido ao foco destes se } \\
\text { concentrar em determinados eventos. Esse trabalho } \\
\text { conjunto teve a finalidade de informar os repórteres } \\
\text { em campo sobre outros eventos em progresso. }\end{array}$ \\
\hline $\begin{array}{l}\text { O retorno que tínhamos da redação deveria } \\
\text { servir como uma espécie de retaguarda para eles } \\
\text { [repórteres]: além de ter televisões ligadas em } \\
\text { diferentes canais para ver o que estava } \\
\text { acontecendo e [acessar canais da] internet o } \\
\text { tempo inteiro, e para mim [foram úteis] as redes } \\
\text { sociais: Twitter, porque a velocidade da } \\
\text { informação era muito grande para ver se alguma } \\
\text { coisa [fato] estava acontecendo em determinado } \\
\text { evento ou atleta [...] no dia que o Brasil ganhou } \\
\text { a medalha de ouro no futebol, pouco tempo } \\
\text { depois, teve um brasileiro ganhou uma } \\
\text { medalha. Aí, todo mundo estava focado no } \\
\text { futebol e a gente estava acompanhando em uma } \\
\text { das televisões e, quando percebemos que } \\
\text { poderia sair uma medalha e daí o pessoal estava } \\
\text { focado para o evento principal, o futebol, que } \\
\text { era no Maracanã para [a partida de] Brasil e } \\
\text { Alemanha. A gente avisou alguém para correr } \\
\text { ao Complexo porque o Brasil poderia ganhar } \\
\text { medalha em outro evento. Então, isso que } \\
\text { fizemos ajudou para dar tempo de o repórter }\end{array}$ & $\begin{array}{l}\text { Além do trabalho abastecer os jornalistas in loco, o } \\
\text { acompanhamento da equipe de redação também } \\
\text { contava com escutas em diferentes canais de } \\
\text { televisão e consultas a várias páginas de internet. A } \\
\text { rede social Twitter teve menção como ferramenta } \\
\text { considerada como grande utilidade devido à } \\
\text { velocidade das publicações: ao mesmo tempo em } \\
\text { que um atleta acabava de ganhar uma medalha, um } \\
\text { outro brasileiro também estaria sendo agraciado em } \\
\text { outra modalidade. } \\
\text { Para tanto, foram acompanhados vários canais e, a } \\
\text { partir da percepção de que um atleta passaria a ter } \\
\text { chances de disputar medalha diante de um evento } \\
\text { principal, como a medalha de ouro no futebol. A } \\
\text { fim de conseguir realizar o devido } \\
\text { encaminhamento, a redação entrava em contato } \\
\text { com um repórter que tinha condições de chegar ao } \\
\text { Complexo Olímpico a tempo de acompanhar a } \\
\text { medalha a outro atleta em eventos quase } \\
\text { simultâneos. }\end{array}$ \\
\hline
\end{tabular}


chegar ao local e acompanhar a medalha do

[atleta brasileiro no] tae-kwon-do.

Para Bullara (2018), houve pouca utilização do conteúdo do site do COB como fonte, mas essa consulta ocorria no caso de atletas que não apareciam como favoritos e que acabavam por se destacar em alguma competição. O profissional enfatiza a importância do trabalho dos jornalistas da redação para auxiliar os correspondentes in loco porque o foco destes eram determinados eventos. Esse trabalho conjunto teve a finalidade de informar os repórteres em campo sobre acontecimentos em progresso. O trabalho da equipe envolvia a realização de escutas em diferentes canais de televisão, bem como acesso a vários sítios da internet.

A rede social Twitter foi mencionada como ferramenta de grande utilidade por causa da velocidade das publicações: ao mesmo tempo que um atleta acabava de ganhar uma medalha, outro brasileiro estava sendo agraciado em outra modalidade.

Entrevistado: Fernando Saraiva, editor do canal SporTV SEGUNDA QUESTÃO: UTILIZOU ALGUM CONTEÚDO DO SITE DO COB? QUAL FOI O CONTEÚDO UTILIZADO?

\begin{tabular}{|c|c|}
\hline UTILIZOU O SITE DO COB? & $\begin{array}{l}\text { SIM } \\
\text { Pouco: agenda de partidas, informações oficiais do } \\
\text { evento e aplicativo móvel para tablet e smartphone }\end{array}$ \\
\hline ENUNCIADO & DESCRIÇÃO ANALÍTICA \\
\hline $\begin{array}{l}\text { A fonte oficial do esporte brasileiro serve para } \\
\text { questões oficiais, por exemplo: casos } \\
\text { específicos, alguém que foi pego no doping, } \\
\text { alguma coisa assim, para você ter uma visão } \\
\text { oficial. Você vai lembrar que muitas } \\
\text { delegações, quando chegaram à Vila Olímpica, } \\
\text { reclamaram das instalações. Então você acaba } \\
\text { indo ali para ver alguma coisa ou outra, mas } \\
\text { sabendo que é uma fonte oficial... Então você } \\
\text { tem que ter uma visão um pouco mais cuidadosa } \\
\text { para lidar com fontes oficiais. }\end{array}$ & $\begin{array}{l}\text { Saraiva pondera o uso do site do COB como fonte } \\
\text { oficial, com base na coordenação dos eventos e a } \\
\text { responsabilidade pelas delegações. Nesse caso, se } \\
\text { há alguma reclamação sobre uma instalação, torna- } \\
\text { se necessária a consulta à fonte oficial e, por esse } \\
\text { motivo, ressalta que as informações oficiais devem } \\
\text { ser consideradas com cuidado e atenção. O } \\
\text { jornalista utilizava o aplicativo do COB em seu } \\
\text { tablet durante a cobertura a fim de manter-se } \\
\text { atualizado. }\end{array}$ \\
\hline $\begin{array}{l}\text { E, para estudo de modalidade não, porque o } \\
\text { SporTV, dois meses antes das Olimpíadas, fez } \\
\text { workshops com todos os profissionais. A gente } \\
\text { não entende muito de remo, e aí vieram os } \\
\text { comentaristas de remo e nos deram um } \\
\text { workshop sobre a modalidade: como é o barco } \\
\text { assim, o barco assado, as distâncias e tal. A } \\
\text { mesma coisa com o hóquei sobre a grama, a } \\
\text { mesma coisa para o levantamento de peso, } \\
\text { enfim, para todos os esportes. Então, tivemos, a } \\
\text { partir do canal, da empresa, uma preparação } \\
\text { muito bacana e, para finalizar, o site do COB, } \\
\text { como uma fonte oficial, a gente acessava } \\
\text { esporadicamente. }\end{array}$ & $\begin{array}{l}\text { Como referência às modalidades, o uso do } \\
\text { conteúdo do site do COB perde relevância por } \\
\text { conta de um esforço empreendido pela empresa } \\
\text { [Globosat] ao realizar workshops com todos os } \\
\text { jornalistas do canal sobre todos os esportes } \\
\text { disputados nos Jogos Olímpicos. Saraiva retoma a } \\
\text { questão ao explicitar taxativamente: referência ao } \\
\text { sítio do COB em caráter esporádico e como fonte } \\
\text { oficial dos eventos. }\end{array}$ \\
\hline
\end{tabular}


Saraiva (2018) pondera o uso do site do COB como fonte oficial, com base na coordenação dos eventos e na responsabilidade em relação às delegações. Nesse caso, se houve alguma reclamação sobre uma instalação, tornou-se necessária consulta à fonte oficial. Ele ressalta que as informações oficiais eram consideradas com cuidado e atenção.

A exceção para esse tipo de consulta foram as referências às modalidades, quando o uso do conteúdo do site do $\mathrm{COB}$ perdeu relevância. O motivo advém de um esforço empreendido pela empresa [Globosat], que realizou workshops com os jornalistas do canal sobre os esportes disputados, dois meses antes dos Jogos.

Entrevistado: Victor Sá Ramalho Antonio, editor do Portal do Rugby SEGUNDA QUESTÃO: UTILIZOU ALGUM CONTEÚDO DO SITE DO COB? QUAL FOI O CONTEÚDO UTILIZADO?

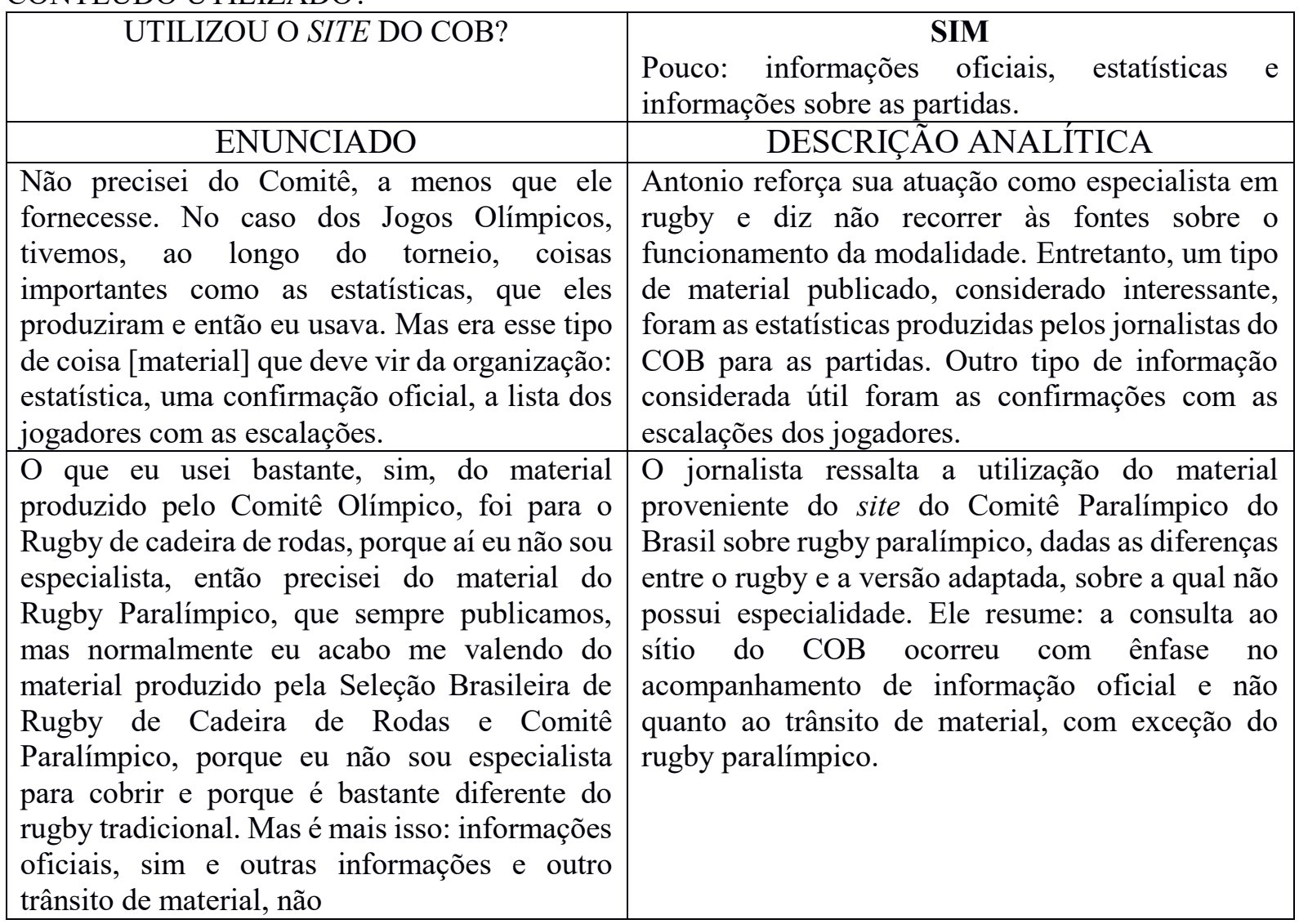

Antonio (2018), especialista em rugby, diz que não utilizou de forma recorrente o site do Comitê. Entretanto, cita um material tido por ele como interessante e publicado na página do $\mathrm{COB}$, a exemplo de estatísticas produzidas por jornalistas durante as partidas.

Outra informação útil foram as confirmações das escalações dos jogadores. O profissional destaca a natureza dessa fonte - o site do $\mathrm{COB}$ - como oficial. Ressalte-se que 
apenas o rugby paralímpico aparece como exceção para a consulta sobre o funcionamento da modalidade pelo motivo de ele não ser especialista.

Entrevistado: Fábio França, editor da Rádio BandNews FM SEGUNDA QUESTÃO: UTILIZOU ALGUM CONTEÚDO DO SITE DO COB? QUAL FOI O CONTEÚDO UTILIZADO?

\begin{tabular}{|c|c|}
\hline UTILIZOU O SITE DO COB? & $\begin{array}{c}\text { SIM } \\
\text { Cadastramento por } e \text {-mail, com avisos de notícias }\end{array}$ \\
\hline ENUNCIADO & DESCRIÇÃO ANALÍTICA \\
\hline $\begin{array}{l}\text { O Comitê Olímpico do Brasil entrava em } \\
\text { contato sempre com a gente, passando links - } \\
\text { não vou lembrar certinho quais eram os } \\
\text { endereços aqui, mas enfim - talvez } \\
\text { semanalmente eles [COB] entravam em contato } \\
\text { por e-mail, mandando links, sugestões e o que } \\
\text { estava à disposição naquela determinada } \\
\text { semana. Existiam outros sites que eram } \\
\text { interessantes e ajudavam bastante na nossa } \\
\text { montagem de conteúdo, na nossa separação de } \\
\text { conteúdo - um clipping mesmo, para ver o que } \\
\text { valia a pena falar ou não. E Olimpíada é algo } \\
\text { muito extenso: são esportes com os quais não } \\
\text { estamos acostumados a lidar. Então, } \\
\text { obviamente, não conhecemos tudo. Ouvimos } \\
\text { falar, mas não sabemos a regra, muitas vezes } \\
\text { não sabemos qual o brasileiro que tem } \\
\text { realmente a chance ou possibilidade de fazer } \\
\text { um bom trabalho em determinado esporte. } \\
\text { Então, esses sites específicos de cada } \\
\text { modalidade são fontes incríveis de busca de } \\
\text { conteúdo. }\end{array}$ & $\begin{array}{l}\text { França menciona o uso do conteúdo do site do } \\
\text { Comitê Olímpico do Brasil por meio de um } \\
\text { cadastro por e-mail, com links direcionados às } \\
\text { matérias, bem como as sugestões a partir do que já } \\
\text { estava publicado. } \\
\text { Também houve a consulta a outros sítios, cujo } \\
\text { material ajudava na montagem e separação de } \\
\text { conteúdo. O jornalista ainda comenta sobre a } \\
\text { extensão do Jogos Olímpicos e dos esportes que } \\
\text { não se está acostumado a lidar. }\end{array}$ \\
\hline $\begin{array}{l}\text { Também uma fonte interessante era um site } \\
\text { interno do Comitê Olímpico Internacional: cada } \\
\text { credenciado ou cada equipe de veículo de } \\
\text { comunicação tinha direito a uma senha que } \\
\text { dava direito a três ou quatro pessoas por } \\
\text { veículo; não lembro ao certo qual era o número } \\
\text { - para acessar às informações. E era muito } \\
\text { legal, com informações absolutamente } \\
\text { detalhadas: estatísticas de cada jogo, de cada } \\
\text { atleta, tudo a respeito da vida de todos atletas } \\
\text { das Olimpíadas. Então, o trabalho do Comitê } \\
\text { Olímpico Internacional foi bastante legal com a } \\
\text { imprensa também. Era uma fonte muito legal de } \\
\text { informação. }\end{array}$ & $\begin{array}{l}\text { Além dos sites especializados, França menciona a } \\
\text { utilização de uma página interna do Comitê } \\
\text { Olímpico Internacional para os jornalistas } \\
\text { credenciados com acesso a informações detalhadas } \\
\text { sobre estatísticas, registros sobre cada competição } \\
\text { e das fases anteriores à classificação. } \\
\text { Entre os jornalistas que tiveram credenciais amplas, } \\
\text { incluindo-se os direitos de transmissão, nenhum } \\
\text { outro entrevistado mencionou em específico a } \\
\text { maneira com que esse acesso à área restrita na } \\
\text { página do IOC ocorreu. Curiosamente, mesmo } \\
\text { assim, a página do COB figura entre as principais } \\
\text { fontes. }\end{array}$ \\
\hline
\end{tabular}

França (2018) menciona o uso do conteúdo do site do COB por meio de um cadastro por e-mail, cujas notificações incluíram links direcionados às matérias. Também houve consulta a outros sítios, cujas informações ajudavam nas pautas a partir da montagem e separação de conteúdo. Além dos sites especializados, França (2018) cita a utilização de 
uma página interna do Comitê Olímpico Internacional para os jornalistas credenciados com acesso a informações detalhadas sobre estatísticas, registros sobre cada competição e fases anteriores à classificação.

Entre os jornalistas que tiveram credenciais amplas, incluindo direitos de transmissão, nenhum outro entrevistado mencionou, em específico, a maneira como esse acesso à área restrita na página do IOC ocorreu.

Entrevistado: Vitor Prates, plantonista esportivo e editor do Blog do Vitor Prates SEGUNDA QUESTÃO: UTILIZOU ALGUM CONTEÚDO DO SITE DO COB? QUAL FOI O CONTEÚDO UTILIZADO?

\begin{tabular}{|c|c|}
\hline UTILIZOU O SITE DO COB? & $\begin{array}{l}\text { SIM } \\
\text { Bastante: fonte confiável e ampla disponibilidade } \\
\text { do material noticioso das Olimpíadas. }\end{array}$ \\
\hline ENUNCIADO & DESCRIÇÃO ANALÍTICA \\
\hline $\begin{array}{l}\text { A gente tentava trazer sempre alguma } \\
\text { informação e tentava buscar sempre essas } \\
\text { informações mais detalhadas, mas o site do } \\
\text { COB trazia essas notícias atualizadas e então, } \\
\text { tentávamos o máximo possível para deixar } \\
\text { igual. }\end{array}$ & $\begin{array}{l}\text { Segundo Prates, a contribuição das publicações de } \\
\text { notícias no site do COB contribuiu para se obter } \\
\text { informações detalhadas e atualizadas. A busca pela } \\
\text { abordagem igual aparece como indício da tentativa } \\
\text { de que as notícias publicadas contemplassem o } \\
\text { maior número possível de provas. }\end{array}$ \\
\hline $\begin{array}{l}\text { [...] o próprio site do COB, dos Jogos } \\
\text { [Olímpicos], às vezes era mais fácil de ter } \\
\text { acesso a notícias, fotos e então a gente utilizava } \\
\text { isso e tentava trazer mais detalhados, para o } \\
\text { leitor do nosso site [o blog], para deixá-los mais } \\
\text { informados. }\end{array}$ & $\begin{array}{l}\text { O plantonista esportivo menciona algumas } \\
\text { facilidades que auxiliaram na usabilidade do } \\
\text { material publicado pelo COB, como os textos das } \\
\text { notícias e da obtenção de fotografias para as } \\
\text { matérias publicadas no Blog do Vitor Prates. }\end{array}$ \\
\hline
\end{tabular}

De acordo com Prates (2018), as publicações de notícias no site do COB forneceram informações detalhadas e atualizadas. Essa contribuição ganhou importância a partir da necessidade de se abordar os assuntos igualmente, como forma de as notícias publicadas contemplarem o maior número possível de competições realizadas.

O profissional menciona algumas facilidades que auxiliaram na usabilidade do material publicado pelo $\mathrm{COB}$, como o acesso a textos noticiosos e a obtenção de fotografias para as matérias publicadas em seu blog.

Entrevistada: Nathália Ely Silveira, repórter do site Travinha SEGUNDA QUESTÃO: UTILIZOU ALGUM CONTEÚDO DO SITE DO COB? QUAL FOI O CONTEÚDO UTILIZADO?

\begin{tabular}{|c|c|}
\hline \multicolumn{1}{|c|}{ UTILIZOU O SITE DO COB? } & \multicolumn{1}{c|}{ SIM } \\
& $\begin{array}{l}\text { Bastante: cadastro e notificação da publicação de } \\
\text { notícias por } \text { e-mail. }\end{array}$ \\
\hline \multicolumn{1}{|c|}{ ENUNCIADO } & DESCRIÇÃO ANALÍTICA \\
\hline $\begin{array}{l}\text { [O Travinha] não era um veículo que poderia } \\
\text { fazer a cobertura das Olimpíadas, mais alguns } \\
\text { releases e alguma coisa... Até hoje, recebo } \\
\text { informações do Comitê Olímpico e alguma }\end{array}$ & $\begin{array}{l}\text { Silveira destaca a utilização do conteúdo noticioso } \\
\text { da página do Comitê como principal fonte durante } \\
\text { a cobertura dos eventos olímpicos no Travinha. } \\
\text { Além de contribuir com a produção de matérias, o }\end{array}$ \\
\hline
\end{tabular}


coisa do site; até hoje eu consulto o site do COB e também do Comitê Paralímpico do Brasil, para me abastecer de informações e procurar alguma coisa que me dê sugestão de pauta. Então, começamos a dar mais valor para isso do que propriamente para as notícias copiadas. Pegamos a Paralimpíada [Jogos Paralímpicos], que eu acho que é um grande evento também, e gostamos de destacar esse outro lado como um site esportivo que dá mais valor para essas outras modalidades, as modalidades olímpicas e ao rugby $\mathrm{XV}$, que não é uma modalidade olímpica, é um esporte amador. Então, procuramos dar destaque para isso, notícias disso também. Mas estamos numa mudança: o site está crescendo, mas era uma maneira diferente de dar a notícia [em 2016] e hoje [2018] as elaboramos da melhor forma. conteúdo do COB também inspirava outras, como sugestão de pauta. Ademais, também houve menção ao conteúdo publicado na página do Comitê Paralímpico do Brasil

A jornalista menciona a produção de notícias a partir das publicações do site do $\mathrm{COB}$, dada a importância na produção de outros acontecimentos esportivos diferenciados para o Travinha.

Silveira destaca a importância de se produzir notícias de esportes consolidados que ainda tem status de amador, sem desenvolvimento no âmbito profissional e de alto rendimento. Ela destaca também o próprio desenvolvimento do Travinha com produções de notícias a partir do desenvolvimento de pautas próprias e diferenciadas desde 2016.

Silveira (2018) aborda o uso das notícias publicadas no site do COB como principal fonte durante a cobertura dos eventos olímpicos para o Travinha. Além da produção de matérias, o conteúdo do Comitê inspirou o desenvolvimento de outros produtos, como as pautas. Além desse sítio, ela salienta que também foram utilizadas as notícias da página do Comitê Paralímpico do Brasil.

Para a jornalista, a produção de notícias de esportes consolidados ainda com status de amadores, sem desenvolvimento no âmbito profissional e de alto rendimento, passou a ter importância em meio aos acontecimentos esportivos.

Ela também destaca o desenvolvimento do próprio sítio Travinha Esportes com pautas próprias e diferenciadas a partir da experiência nos Jogos. "Estamos numa mudança: o site está crescendo", afirma Silveira (2018), valorizando o aprendizado adquirido com o trabalho de cobertura do evento ocorrido no Rio.

Entrevistado: Marcus Von Groll, repórter do site Travinha SEGUNDA QUESTÃO: UTILIZOU ALGUM CONTEÚDO DO SITE DO COB? QUAL FOI O CONTEÚDO UTILIZADO?

\begin{tabular}{|c|c|}
\hline \multirow[t]{2}{*}{ UTILIZOU O SITE DO COB? } & SIM \\
\hline & $\begin{array}{l}\text { Bastante: resultado das partidas e fotografias } \\
\text { publicadas no site. }\end{array}$ \\
\hline ENUNCIADO & DESCRIÇÃO ANALÍTICA \\
\hline $\begin{array}{l}\text { Na verdade, todas as notícias, praticamente, } \\
\text { foram do Comitê, que fez até uma boa cobertura } \\
\text { das Olimpíadas: tinha notícia de tudo, foi } \\
\text { admirável a cobertura que eles fizeram. A gente } \\
\text { procurou pegar e colocar isso. Havia até muitas } \\
\text { matérias específicas do próprio Comitê: dos } \\
\text { bastidores, de como estava o ambiente externo }\end{array}$ & $\begin{array}{l}\text { Para o jornalista, o uso do conteúdo do site do COB } \\
\text { impactou na produção de notícias publicadas no } \\
\text { Travinha. O jornalista destaca a abrangência das } \\
\text { notícias publicadas pela instituição e o âmbito de } \\
\text { cobertura, desde as competições até o ambiente } \\
\text { externo, bem como as informações institucionais } \\
\text { sobre gastos e investimentos. Como o Travinha se }\end{array}$ \\
\hline
\end{tabular}


dos locais. Também havia notícias mais na questão institucional, de gastos, investimentos. encontrava na fase inicial, não ocorreu maior desenvolvimento na produção as informações a partir de conteúdos diferenciados provenientes do COB.

Groll (2018) reconhece que foi utilizado aproximadamente quase todo conteúdo do site do COB, o que impactou diretamente na produção de notícias publicadas no Travinha. O jornalista destaca a forma de cobertura das notícias publicadas pela instituição e o âmbito das informações: desde as competições até o ambiente externo, bem como os assuntos institucionais de gastos e investimentos.

Como o Travinha se encontrava na fase inicial, Groll (2018) também considera que, naquele momento, havia pouca disponibilidade de fontes para tratar conteúdos diferenciados e grande parte destas provinha da página do $\mathrm{COB}$.

Entrevistado: Geraldo Armando Cardoso Neto, editor da EPTV Ribeirão Preto SEGUNDA QUESTÃO: UTILIZOU ALGUM CONTEÚDO DO SITE DO COB? QUAL FOI O CONTEÚDO UTILIZADO?

\begin{tabular}{|c|c|}
\hline UTILIZOU O SITE DO COB? & $\begin{array}{c}\text { SIM } \\
\text { Pouco: informações dos atletas confederados. }\end{array}$ \\
\hline ENUNCIADO & DESCRIÇÃO ANALÍTICA \\
\hline $\begin{array}{l}\text { Nós dividimos essa produção olímpica em } \\
\text { setores, mas essa questão da pauta ficou muito } \\
\text { ligada a um produtor, na época, que hoje virou } \\
\text { editor, que é o Saulo [Prieto Degrande]. Então, } \\
\text { obtínhamos as informações não só do site [do } \\
\text { COB] - a gente compilava as informações de } \\
\text { todas as modalidades através de redes sociais, } \\
\text { através de divulgações de notas oficiais das } \\
\text { entidades. Então, claro que o site do Comitê } \\
\text { Olímpico [do Brasil] foi importante. Nós } \\
\text { pincelamos as informações importantes do site, } \\
\text { mas não ficamos só no site. Nós fizemos uma } \\
\text { série, uma abordagem geral, nós garimpamos } \\
\text { realmente os atletas, a história dos atletas, a } \\
\text { família dos atletas. Então o site do COB foi } \\
\text { importante para a questão do nosso } \\
\text { embasamento: atletas classificados, que iriam } \\
\text { participar, então isso foi muito importante. Mas } \\
\text { nó tivemos um trabalho de garimpar, de } \\
\text { vasculhar - vamos dizer assim, em outras redes } \\
\text { de outros meios, como é o Jornalismo. }\end{array}$ & $\begin{array}{l}\text { Cardoso Neto enfatiza a produção das notícias a } \\
\text { partir dos trabalhos da equipe de reportagem. Nesse } \\
\text { caso, o produtor Saulo Prieto Degrande fazia } \\
\text { consulta de fontes enquanto os repórteres } \\
\text { buscavam reunir as informações dos atletas da } \\
\text { região de Ribeirão Preto por meio das páginas em } \\
\text { redes sociais desses esportistas e a divulgação de } \\
\text { notas oficiais das instituições, como as federações. } \\
\text { O jornalista destaca a importância do conteúdo } \\
\text { noticioso a partir do site do COB como importante } \\
\text { para o embasamento o o trabalho de preparo das } \\
\text { notícias se concentrou no contato e localização } \\
\text { daqueles atletas locais que participariam das } \\
\text { reportagens. }\end{array}$ \\
\hline
\end{tabular}

Para Cardoso Neto (2018), a produção das notícias teve um direcionamento específico nas funções desempenhadas pela equipe de reportagem: a consulta de fontes, entre elas, o site do COB. O produtor Saulo Prieto Degrande ficava encarregado de buscar o conteúdo informativo, enquanto os repórteres se concentravam na compilação dos atletas 
da região de Ribeirão Preto por meio das páginas em redes sociais desses esportistas e das notas oficiais das instituições, como as federações.

O jornalista destaca o conteúdo do site do $\mathrm{COB}$ como importante para o embasamento e o trabalho de preparo das notícias. O fato de não mencionar o conteúdo produzido a partir da Rede Globo assume uma característica relevante ao tornar evidente a necessidade da regionalização das reportagens. No caso, Ribeirão Preto, no estado de São Paulo.

Entrevistado: Sérgio Settani Giglio, produtor do site Ludopédio SEGUNDA QUESTÃO: UTILIZOU ALGUM CONTEÚDO DO SITE DO COB? QUAL FOI O CONTEÚDO UTILIZADO?

\begin{tabular}{|c|c|}
\hline UTILIZOU O SITE DO COB? & $\begin{array}{l}\text { NÃO } \\
\text { Optou pela utilização de um site com atribuição em } \\
\text { Creative Commons a fim de evitar problemas } \\
\text { envolvendo os direitos (transmissão e marca) dos } \\
\text { Jogos Olímpicos. }\end{array}$ \\
\hline ENUNCIADO & DESCRIÇÃO ANALÍTICA \\
\hline $\begin{array}{l}\text { Não utilizamos conteúdo produzido pelo } \\
\text { Comite. Utilizamos o material produzido pela } \\
\text { Agência Brasil, que é vinculada ao governo } \\
\text { federal, porque eles produzem um material via } \\
\text { licença Creative Commons. Então, por } \\
\text { exemplo, boa parte das fotos que acabamos } \\
\text { usando vinham desse lugar, porque estavam } \\
\text { previamente autorizadas. Mas nenhuma outra } \\
\text { fonte oficial, nesse sentido foi utilizada, } \\
\text { tampouco do próprio COI (Comitê Olímpico } \\
\text { Internacional-IOC). Não acabamos recorrendo } \\
\text { até porque eles [comitês] sempre colocam } \\
\text { algumas amarras do ponto de vista dos direitos } \\
\text { autorais daquele material e é muito difícil } \\
\text { publicar esse material e se republicar e } \\
\text { recolocar isso em outro lugar. }\end{array}$ & $\begin{array}{l}\text { Giglio apresenta uma justificativa que impediu uma } \\
\text { utilização a partir de entraves referentes a direitos } \\
\text { autorais: da marca Jogos Olímpicos Rio } 2016 \text { e da } \\
\text { divulgação de notícias. Como o Ludopédio possui } \\
\text { viés acadêmico, a perenidade dos conteúdos } \\
\text { poderia ser passível de retirada de temas não } \\
\text { autorizados após a realização dos eventos. } \\
\text { Com base nas possíveis amarras referentes aos } \\
\text { direitos reservados às instituições dos Jogos } \\
\text { Olímpicos, Giglio optou pela referência a } \\
\text { conteúdos que pudessem ser republicados de } \\
\text { maneira indiscriminada, no site Ludopédio e em } \\
\text { trabalhos derivados desse material. }\end{array}$ \\
\hline
\end{tabular}

O caso apresentado por Giglio (2018) aparece como o único que não utilizou qualquer informação proveniente das instituições relacionadas aos Jogos Olímpicos, nem o COB, nem do IOC. Os entraves percebidos tratavam da limitação de direitos autorais da marca Jogos Olímpicos Rio 2016 e da divulgação de notícias. O site possui condições criteriosas com conteúdo passível de retirada por meio do uso ‘não autorizado' referente aos eventos.

Com base nas possíveis amarras relacionadas aos direitos reservados às instituições dos Jogos Olímpicos, Giglio (2018) optou pelo uso de conteúdos que pudessem ser republicados de maneira indiscriminada no Ludopédio, bem como por trabalhos derivados 
desse material. Uma questão, em especial, remete a um possível conflito de interesses referentes ao licenciamento de marcas: a escolha e o licenciamento das cidades-sede versus a perenidade dos estudos acadêmicos em caráter atemporal com os períodos de realização dos Jogos Olímpicos.

\subsubsection{Análise crítica dos resultados}

A partir dos dados obtidos, foi percebido o seguinte padrão quanto à importância da cobertura jornalística, à utilização de fontes e ao desenvolvimento das pautas esportivas durante os Jogos Olímpicos de 2016: os jornalistas consultados estavam envolvidos nos esforços dos canais de comunicação que produziram notícias. Essa percepção remete claramente à fala do diretor de comunicação do COB, Motta (2017), durante a visita técnica realizada ao COB.

Sempre que possível, os profissionais da imprensa preferiram participar da cobertura in loco e, na impossibilidade de presenciar os eventos, por falta de credenciamento ou dificuldade financeira, as informações provenientes de locais confiáveis acabaram por ter participação fundamental tanto quanto a cobertura à distância. Entre os principais exemplos destacam-se os jornalistas com atuação na mídia independente (sites e blogs) que não contaram com recursos nem credenciamento para produzir as notícias a partir dos locais das provas.

O site do COB mereceu destaque tanto por parte dos canais alternativos como dos grandes veículos de comunicação. Em nenhum caso, vale destacar, foi levantada suspeita quanto à qualidade e credibilidade do conteúdo advindo do sítio do Comitê Olímpico do Brasil.

Uma importante diferença percebida nos jornalistas que atuaram na grande mídia (em contraposição àqueles da mídia alternativa) durante os Jogos Olímpicos aparece na menção ao processo de produção de notícias in loco, como a disposição de maior número de fontes (pessoas e sites) e a ampliação das pautas. Nesse aspecto, a percepção do conteúdo do COB não ocorreu em âmbito primordial e alguns realces que apareceram trataram da natureza e da abrangência:

- Institucional: o COB como coordenador da maioria dos eventos das Olimpíadas, além de ser o responsável pela delegação dos atletas brasileiros. 
A partir dessa dinâmica, as informações divulgadas partem de uma fonte oficial;

- Credibilidade: alguns conteúdos complementares, como as fichas com dados sobre os atletas brasileiros, entre os quais os não favoritos às medalhas; a publicação da agenda dos eventos diários durante os Jogos Olímpicos, inclusive com a divulgação de mudanças de última hora ou escalação de equipes, placares, fotografias e resultados das competições. De forma geral, entram em destaque as principais informações, embora algumas matérias com profundidade e a participação de pessoas ligadas ao entorno dos locais de competição demonstrassem contribuir como um dos diferenciais apontados pelos jornalistas consultados.

A questão da cobertura mencionada pelos profissionais da imprensa permite articular outro fator decisivo que impactou na utilização recorrente do site do COB como fonte: a produção de notícias fora dos locais dos eventos. Como a questão do credenciamento do trabalho in loco não teve ligação com as perguntas, considera-se que, quando a descrição sobre os trabalhos de cobertura resvala nesse entrave, torna-se possível correlacionar a diminuição do número de fontes à dificuldade do acompanhamento dos Jogos Olímpicos à distância.

Diante desse cenário, a utilização de material divulgado pelo sítio do COB ganha mais relevância, embora fique constatado que, havendo possibilidade, o jornalista não dependeria exclusivamente de fontes de cunho institucional. Ou seja: existe uma perspectiva de independência do trabalho publicado, mesmo que, ao contar com a atuação de jornalistas em um departamento de comunicação, o COB, enquanto fonte, acabe incluído como uma voz proveniente de uma instituição no processo de tratamento noticioso por parte dos repórteres que cobriram os Jogos.

Em relação ao tratamento noticioso, um assunto abordado anteriormente tem referência com a maneira como usuários-interatores (GARCIA, 2011) se expressam em redes sociais, eventualmente, suscitando um afloramento emocional diante de temas que extrapolam as competições.

Esse tipo de questão pode ser exemplificado diante da ocorrência de fatos registrados em novembro de 2017, cuja manifestação de usuários em uma página não oficial do Facebook possui menção ao $\mathrm{COB}$. Os três motivos para o registro de reação de teor emocional foram: 
- A 'janela’ olímpica iniciada após o evento do Rio, em setembro de 2016, e que deve durar até 2020;

- Insatisfação com a destinação de obras de infraestrutura temporárias (como o velódromo, os ginásios olímpicos sem arrendamento e a ciclovia Tim Maia, que teve um trecho danificado por uma onda proveniente de ressaca marítima);

- O indiciamento e prisão do então dirigente do COB, Carlos Arthur Nuzman (em outubro de 2017) $)^{40}$.

Ao se considerar tais motivos como causadores do constrangimento de usuários em canais não oficiais em rede social, toma-se como referência a ilustração a seguir, que exibe a publicação de comentários de teor emocional num canal dedicado à instituição. Trata-se de uma página não oficial do Comitê Olímpico Brasileiro, no Facebook, como a expressão de frustração relativa a diversos assuntos, como a percepção da parcialidade no trabalho de norte-americanos em relação à prisão que culminou na renúncia de Nuzman como presidente do COB:

Figura 15 - Página não oficial do COB no Facebook

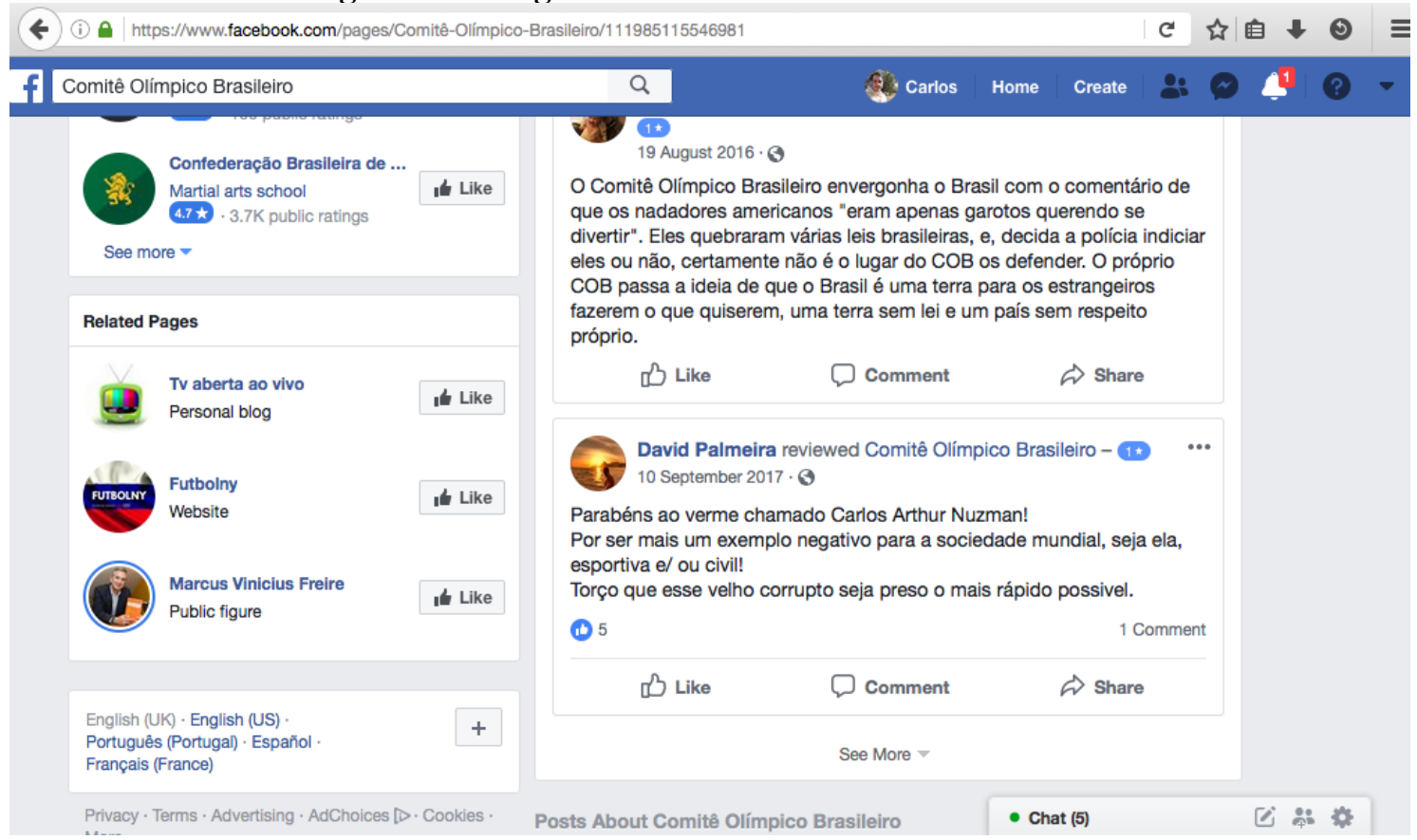

Fonte: $<$ https://www.facebook.com/pages/Comitê-Olímpico-Brasileiro/11198511554>

${ }^{40} \mathrm{O}$ ex-jogador de vôlei e advogado Carlos Arthur Nuzman foi denunciado em 2017 e investigado pela Operação Unfair Play na Polícia Federal, que apura a compra de votos referente à escolha da sede dos Jogos Olímpicos de 2016. Informação publicada em outubro de 2017. Disponível em: $<$ https://oglobo.globo.com/esportes/mp-denuncia-cabral-nuzman-mais-quatro-apos-operacao-unfair-play21960489>. Acesso em: 29 nov. 2018. 
As opiniões manifestadas em relação à figura acima ilustram a questão da expressão de usuários-interatores (GARCIA, 2011) nos noticiários esportivos. Assim, faz-se necessária a retomada das seguintes falas já registradas nesta tese:

Quadro 5 - Paixão e emoção: síntese

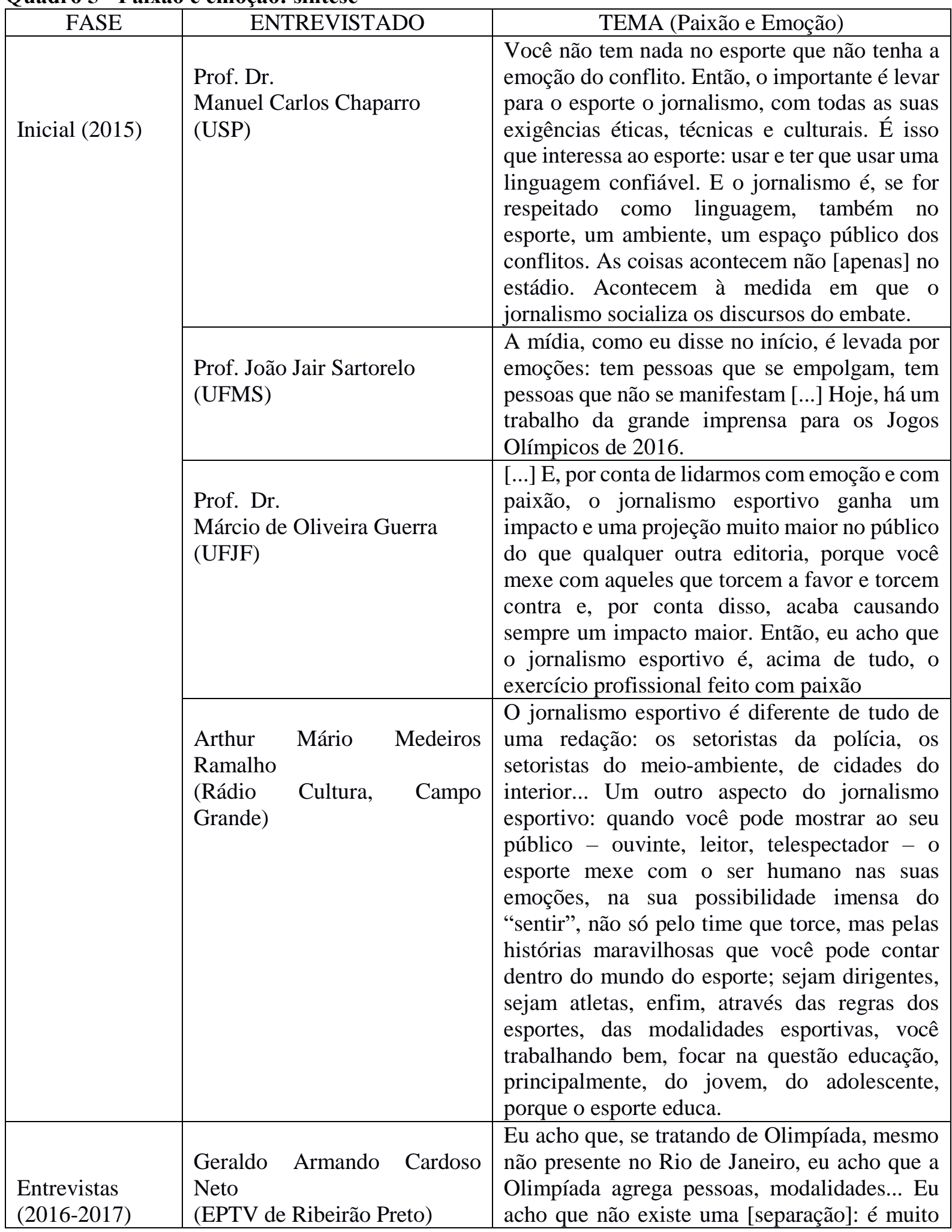




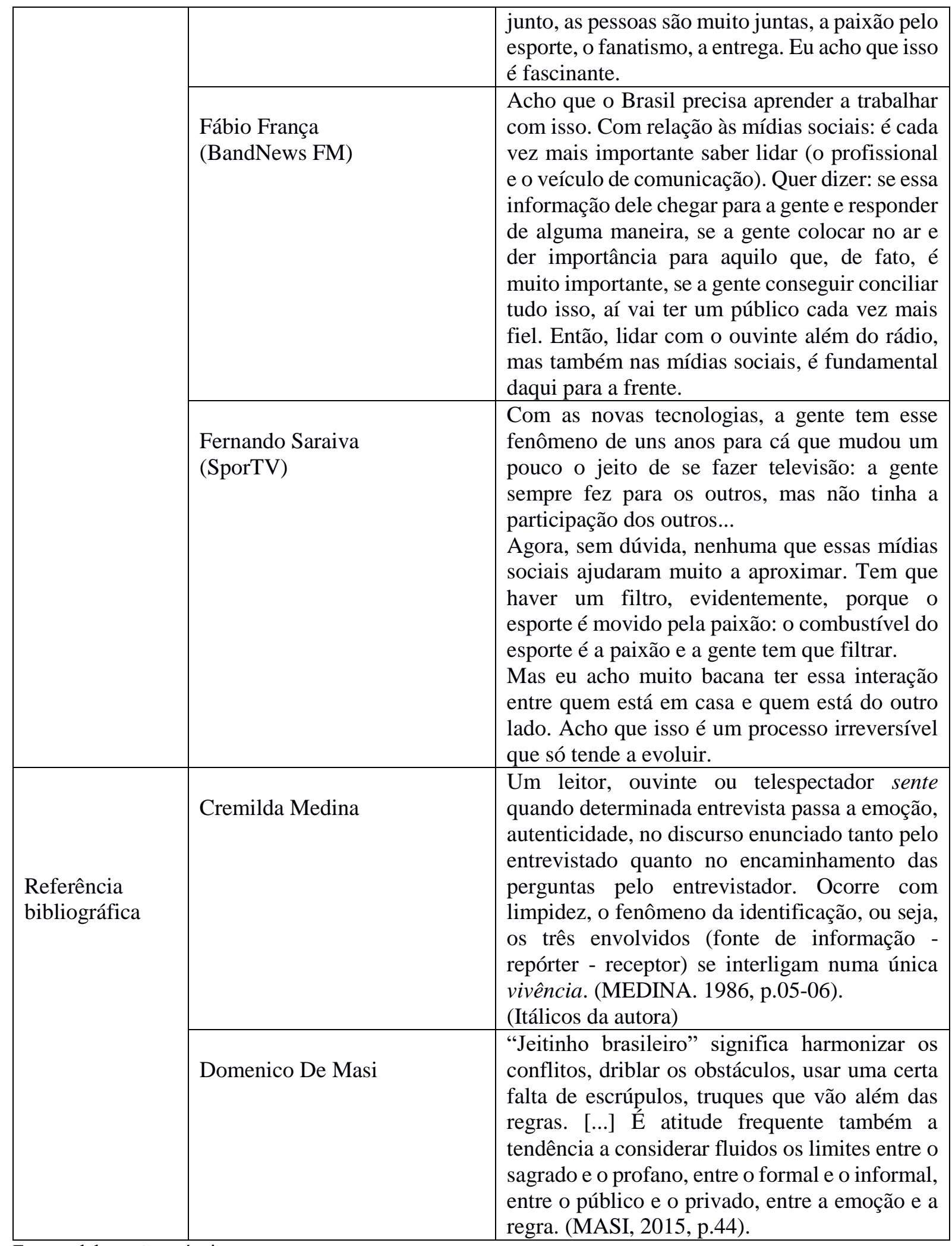

Fonte: elaboração própria

As menções a 'paixão e emoção' relacionadas aos esportes demonstram uma característica fundamental no jornalismo esportivo. Por esse motivo, elas foram consideradas a partir do registro com as falas dos pesquisadores Chaparro (da USP), Guerra 
(da UFJF) e Sartorelo (da UFMS), dos jornalistas Ramalho (da Rádio Hora), França (da BandNews FM), Cardoso Neto (da EPTV) e Saraiva (do SporTV) e a partir da referência bibliográfica de Medina (2014) e Masi (2015). Para todos eles, o esporte, culturalmente, encontra-se vinculado a expressões da emoção, principalmente por parte dos espectadores que o acompanham na mídia.

Devido ao enraizamento cultural e ao sentimento apresentarem correlações, torna-se importante estabelecer a seguinte consideração: cabe ao jornalismo esportivo e, sobretudo, aos jornalistas, a tarefa de lidar com a mediação (MARTíN-BARBERO, 2010) dos fatos. Independentemente da manifestação sobre atletas, clubes e equipes, a obrigação e o compromisso do jornalismo com os acontecimentos tornam-se, mais uma vez, necessários diante dos valores profissionais da atividade. Hohenberg (1981, p.08-09) elenca esses requerimentos:

[...] a primeira regra do jornalismo é não tomar nada como certo. Não há dúvida de que o jornalista sério tende a questionar os valores estabelecidos e a sabedoria convencional em extensão maior do que qualquer outro profissional. E assim deve ser.

O ceticismo sempre foi a marca registrada do jornalismo. Nenhuma organização noticiosa poderá subsistir se registrar frequentemente satisfação em relação às coisas como elas são, se não pesquisar por baixo da realidade aparente, se falhar em soar o alarme diante das fraquezas da sociedade.

Diante das incertezas e das demandas culturais que as suscitam, o estabelecimento das práticas profissionais contribui para consolidar as fontes de natureza reconhecida pelos jornalistas como forma de dinamizar o repertório em relação à pauta. A utilização de informações jornalísticas torna-se importante diante da necessidade que o próprio registro de acontecimentos impõe. Dessa maneira, a cobertura esportiva in loco e à distância acabam por abranger referências reais (interpessoal) e virtuais (redes cibernéticas).

No quadro a seguir, com base nos registros e inferências a partir dos entrevistados, aponta-se para premissa referente à cobertura in loco e como os custos com credenciamento e envio de correspondentes impactaram as atividades de produção noticiosa durante as Olimpíadas de 2016 no Rio de Janeiro: 
Quadro 6 - Premissa e hipótese: síntese

\begin{tabular}{|c|l|}
\hline PREMISSA & $\begin{array}{l}\text { Quanto menos credencial o jornalista possuir, mais probabilidade de } \\
\text { recorrer ao site do COB como fonte para a produção de notícias. }\end{array}$ \\
\hline HIPÓTESE & $\begin{array}{l}\text { O site do COB serve como fonte, prioritariamente como retaguarda em } \\
\text { redações, ajudando nas pautas e nos repertórios dos repórteres in loco. Para } \\
\text { jornalistas esportivos que não têm como estar nos eventos, esse sítio torna- } \\
\text { se uma fonte essencial de consulta e referência devido aos recursos } \\
\text { oferecidos, como placar, fichas de atletas e informações de partidas. }\end{array}$ \\
\hline
\end{tabular}

Fonte: elaboração própria

A partir de uma perspectiva de estudos comparados, procurou-se estabelecer uma relação entre a forma como a mídia brasileira e jornalistas de Portugal fizeram a cobertura dos Jogos Olímpicos em 2016 no Rio de Janeiro. O recorte da pesquisa tratará desse tema a seguir.

\subsection{Os Jogos do Rio 2016 em Portugal}

Com referência ao trabalho de jornalistas em Portugal, Pinto (2017) menciona algumas normas de atuação profissional. Em especial, uma restrição se destaca: a proibição do acúmulo dos cargos de jornalista e assessor de imprensa:

Não se trata apenas de uma opinião, trata-se de um aspecto positivo, factual, de Portugal e, em geral, na Europa acontece também: o jornalista não pode legalmente exercer qualquer trabalho que se assemelhe à produção de pessoas, instituições, produtos e serviços. Toda a atividade de relações públicas, de publicidade, de comunicação organizacional, de assessoria está completamente vedada ao jornalista enquanto ele está exercendo a profissão. Não quer dizer que não possa exercer essas funções, mas essas funções, para exercer, o jornalista tem que entregar a sua carteira profissional e, portanto, fica vedado o uso até da palavra jornalista. Ele não pode se definir como jornalista sob pena de ter sua carteira cassada, no sentido literal, ele pode ter que voltar a obtê-la. Mas, digamos, isso é uma defesa, em nosso ponto de vista, do cidadão e da cidadania, porque se pretende evitar que o jornalista se possa ver confrontado com um conflito de interesses. Não quer dizer que isso aconteça sempre, mas é uma medida de precaução. Eu diria que isto é uma forma de dignificar a função da assessoria, das relações públicas e da publicidade porque, muitas vezes, há um discurso entre nós, entre os jornalistas, considerando que essas funções são menores, são um pouco contaminadas por interesses como se a do jornalista não fosse. $\mathrm{O}$ que eu defendo é que deve haver uma ética da profissão de relações públicas; de relações públicas, de assessor, de publicitário tal como nós temos uma ética do jornalismo.

Além da obrigatoriedade, a fiscalização do trabalho do jornalista profissional fica a cargo da Comissão da Carteira Profissional de Jornalista (CCPJ) e outro requisito interessante diz respeito à escolha do nome profissional. Essa 'alcunha' tem a finalidade de 
ser singular e, no caso de homônimos, obriga o jornalista a utilizar outro nome. A aposentadoria de profissionais também libera o uso do nome da pessoa que então se retirou do serviço. Este breve cenário ajuda a introduzir e contextualizar a profissão em terras lusitanas.

No período de 29 de setembro a 08 de dezembro de 2017, durante o estágio doutoral discente na Universidade do Minho (UMINHO), em Portugal, foram consultados jornalistas portugueses que atuam nas seções dos esportes e que cobriram os Jogos Olímpicos para a mídia daquele país. Essa consulta considerou, a priori, a relevância dos aspectos locais, regionais e internacionais a partir da cidade de Lisboa (capital), da região do Porto (principal cidade da região do Minho, no norte de Portugal), além de Braga (local do campus Gualtar, da UMINHO).

Os jornalistas portugueses consultados foram:

- Daniel Vieira da Silva: jornalista e diretor da Rádio Universitária do Minho. A entrevista ocorreu no dia 17 de outubro de 2017, nas dependências da emissora, em Braga. A escolha teve a finalidade de verificar como foi tratado o enfoque dos Jogos Olímpicos no âmbito de uma estação local e universitária;

- Carlos Miguel Machado: jornalista e repórter esportivo do jornal Correio do Minho. Entrevistado em 30 de outubro de 2017, no campus Gualtar, da UMINHO, em Braga. Nesse caso, optou-se pela análise do trabalho jornalístico desenvolvido em um impresso de circulação regional;

- Carlos Flórido: jornalista editor do jornal esportivo O Jogo. Consultado em 16 de novembro de 2017, na sucursal do Porto do grupo Media Capital. A escolha desse veículo considerou tanto a publicação da versão impressa como a manutenção de um site. Outra característica que contribuiu para essa escolha se relaciona à manutenção de uma seção destinada a outras modalidades;

- Fernando Eurico: jornalista e locutor esportivo da rádio Antena $1^{41}$ e do canal de televisão RTP. A entrevista foi concedida no dia 30 de novembro de 2017, nas dependências da RTP, no Porto. A escolha desses canais, tida como prioritária, buscou constatar algumas nuances da cobertura dos Jogos in loco por meio de emissoras de rádio e televisão, com a finalidade de entender a consulta de fontes,

\footnotetext{
${ }^{41}$ A emissora Antena 1, conhecida anteriormente como Rádio Nacional (de Portugal), tem origem pública e não possui vínculo com a rede homônima que atua no Brasil, de caráter privado.
} 
inclusive das ferramentas oferecidas pelo IOC às equipes que atuavam em emissoras que haviam obtido direitos de transmissão;

- Pedro Jorge da Cunha: jornalista e editor do site Maisfutebol. A entrevista foi registrada nas dependências da sucursal do Global Media Group, no Porto, em 06 de dezembro de 2017. A escolha desse sítio partiu da necessidade de obtenção de relatos de jornalistas que atuassem em canais de internet e, nesse caso, que houvessem participado da cobertura in loco no Rio de Janeiro em 2016.

Apesar do aspecto primordial da atuação desses jornalistas vinculados à produção de notícias da delegação portuguesa, a busca pelos entrevistados teve a finalidade de averiguar junto a essa imprensa a consulta de fontes do Brasil, entre elas, o site do COB. Diferentemente dos profissionais da imprensa brasileira que foram consultados nos subitens anteriores, todas as cinco pessoas que atuam em Portugal têm formação universitária em Comunicação Social com habilitação em jornalismo, com registro profissional junto à CCPJ.

\subsubsection{A cobertura dos Jogos Olímpicos no Rio de Janeiro em 2016 por jornalistas portugueses}

Essa seção reúne os trechos dos depoimentos e as análises referentes à primeira questão sobre a cobertura jornalística dos Jogos Olímpicos de 2016. Essa questão tem um caráter comparativo, de discutir a atuação específica de cada colaborador no âmbito estrangeiro. Diante disso, o principal motivo consiste no próprio acompanhamento das Olimpíadas a cada quatro anos a partir de um país. A perspectiva do olhar dos jornalistas portugueses tem o objetivo de resgatar os diferentes âmbitos e abordagens por profissionais estrangeiros que vieram ao Brasil para cobrir os eventos e em diferentes possibilidades a partir da variedade de pautas desenvolvidas pelos entrevistados.

Entrevistado: Daniel Vieira da Silva, diretor da Rádio Universitária do Minho PRIMEIRA QUESTÃO: A COBERTURA DOS JOGOS OLÍMPICOS DE 2016

\begin{tabular}{|c|c|}
\hline ENUNCIADO & DESCRIÇÃO ANALÍTICA \\
\hline $\begin{array}{l}\text { A cobertura foi quase que a nível nacional, foi } \\
\text { um olhar muito atento àquilo que os atletas } \\
\text { portugueses iam fazendo nos Jogos Olímpicos. } \\
\text { Mas acho que é importante lembrar que em } \\
\text { Portugal, os Jogos Olímpicos começaram a ser } \\
\text { falados muito mais cedo em nosso país por } \\
\text { causa dos atrasos nas [obras de] infraestruturas } \\
\text { que iam receber as várias modalidades e os }\end{array}$ & $\begin{array}{l}\text { Daniel Vieira da Silva destaca as características da } \\
\text { cobertura esportiva do evento internacional } \\
\text { realizado no Brasil a partir das demandas locais (a } \\
\text { delegação portuguesa) e de proximidade (assuntos } \\
\text { de preocupação com as obras de infraestrutura). O } \\
\text { fato de Portugal ter participado da história do Brasil } \\
\text { e vice-versa ficou evidenciado pelo tom de } \\
\text { inquietação sobre os atrasos nas obras. Nesse caso, }\end{array}$ \\
\hline
\end{tabular}


Jogos Olímpicos começaram a ser preparados com muitos anos de antecedência e percebemos que há poucos dias do início do evento havia infraestruturas que ainda não estavam preparadas [...] os Jogos Olímpicos começaram a ser efetivamente a ser falados em Portugal com mais força uns dias antes da abertura por causa desses fatores ligados aos atrasos nessas obras.

Nosso foco em Portugal foi para os atletas: acompanhamos a missão portuguesa, todos os atletas, todos aqueles que iriam representar o país nos Jogos, acompanhamos com muita atenção os momentos iniciais, a cerimônia de abertura e tínhamos todos os dias bem definido um calendário, não me lembro quantos, mas que fossem 80 atletas, nós conseguimos, por dia, saber o horário das competições e onde tínhamos que ligar em qual canal e qual [emissora de] rádio para acompanhar aquele atleta português e fazíamos esse acompanhamento numa perspectiva nacional, os atletas favoritos a medalhas eram aqueles mais falados, o foco das atenções e, mesmo antes de saírem de Portugal, eram campeões do mundo, da Europa e os mais visados da opinião pública [...] No caso da Rádio Universitária do Minho, há atletas que são originários da região de Braga, do Minho, norte de Portugal, em que demos uma atenção diferente: temos um atleta que era estudante da Universidade do Minho, no ano passado e era o número 2 mundial de taekwon-do e foi nessa condição para os Jogos Olímpicos e, naturalmente nós falamos com o atleta antes e depois das lutas e fazíamos entrevistas ao vivo porque ele tinha uma relação muito próxima com a universidade e com a RUM [...] nós viramos a atenção para esse atleta porque ele teve uma participação interessante.

Nós fomos acompanhando tudo o que eles iam fazendo de uma forma igual para todos, tanto demos destaque para um atleta de tae-kwon-do, como para uma atleta de ginástica artística, como demos atenção a competidores do atletismo, porque Portugal tinha mais atletas competindo no atletismo e muitos deles, favoritos a medalhas. Por isso, olhamos de forma igual para eles e tentamos dar um acompanhamento igual. Como isso se refletia nos nossos noticiários esportivos? Numa segunda-feira, poderíamos abrir com o tae-kwondo, como no dia seguinte falamos sobre o futebol que estava acontecendo aqui em Portugal. Durante o período dos Jogos Olímpicos, era uma forma de as modalidades serem faladas e nós aproveitamos essa onda crescente, de se falar e explicar muitas em vez da recorrência aos assuntos esportivos, dos atletas portugueses em fase de preparação e das expectativas de medalhas. No lugar de mencionar o cenário com matérias que enfatizassem as críticas, as notícias referentes aos atrasos das obras de infraestrutura, ligadas às preparações do evento, reforçaram a noção de proximidade entre Portugal e Brasil.

O jornalista enfatiza o baluarte da cobertura jornalística de eventos esportivos internacionais: ao se partir dos âmbitos local, regional e nacional, como a delegação dos atletas portugueses e as notícias relacionadas a eles. Também ficou enfatizada a abrangência da cobertura dos eventos das Olimpíadas, desde a abertura, as competições que envolveram os atletas portugueses, os esportistas que se destacavam nas provas até a cerimônia de encerramento dos Jogos.

Silva também aponta outras fontes de acompanhamento em tempo real para a consulta a partir da redação da Rádio Universitária do Minho, como escuta de canais de rádio e televisão que transmitiam as partidas ao vivo nos horários agendados dos eventos. Também ficou evidenciada a questão local, a partir da cidade de Braga, depois a região do Minho. $\mathrm{O}$ fato de ter existido um contato prévio com um atleta que foi aluno da Universidade do Minho contribuiu para atender à demanda da cobertura a partir do local. A proximidade com esse competidor olímpico que também representava um certo favoritismo em termos locais e também relacionados à Universidade.

Além do atleta que passou pela Universidade do Minho, o foco da cobertura se diversificou a partir das modalidades que possuíam atletas portugueses, como ginástica artística e atletismo. Além da quantidade de esportistas, alguns tinham o destaque do favoritismo. Para dar um tratamento igual aos competidores da delegação portuguesa, Silva menciona a abordagem temática nos noticiários e no caso de a modalidade ter pouca familiaridade e mesmo com favoritos à medalha, foi escolhido o tratamento didático com explicações do esporte em questão.

O jornalista ressalta que o período olímpico também serviu como forma de dar visibilidade a outros esportes por meio do acompanhamento dos 
vezes essas modalidades para trazermos para nossa programação esses tipos de conteúdo e fomos acompanhando os resultados em quase um mês de competição. resultados ao produzir notícias ao longo do evento realizado no mês de agosto de 2016.

A cobertura esportiva da Rádio Universitária do Minho foi realizada à distância, por meio do acompanhamento de fontes jornalísticas, com ênfase na perspectiva de atletas portugueses nos âmbitos local, regional e nacional. A proximidade entre Portugal e Brasil ficou evidenciada por meio de notícias referentes à fase de preparação dos Jogos, cujo tema recorrente abordou o atraso na entrega das obras de infraestrutura.

Daniel Vieira da Silva (2017) menciona também a aproximação com os atletas locais a fim de facilitar a cobertura, como o caso do atleta olímpico de tae-kwon-do, ex-aluno da UMINHO. Silva (2017) ainda destaca o período dos Jogos para enfatizar e explicar as modalidades com pouca visibilidade no noticiário. Ressalte-se que Portugal teve mais atletas favoritos a medalhas no atletismo.

Entrevistado: Carlos Miguel Machado, repórter do jornal Correio do Minho PRIMEIRA QUESTÃO: A COBERTURA DOS JOGOS OLÍMPICOS DE 2016.

\begin{tabular}{|c|c|}
\hline ENUNCIADO & DESCRICÃO ANALÍTICA \\
\hline $\begin{array}{l}\text { Em nosso foco de interesse havia a participação } \\
\text { de vários atletas olímpicos da aqui região do } \\
\text { Minho, atletas minhotos - por outro lado, é uma } \\
\text { competição internacional, a mais prestigiada em } \\
\text { escala global e os Jogos Olímpicos [que] tem } \\
\text { muito interesse do nosso público. Daí que } \\
\text { fizemos uma cobertura um pouco extensa dentro } \\
\text { da dimensão do nosso jornal - somos um jornal } \\
\text { regional, com publicação diária e, como } \\
\text { tínhamos também muitos atletas minhotos } \\
\text { participando dos Jogos, procuramos } \\
\text { corresponder àquilo que era do interesse do } \\
\text { nosso público perante a participação desses } \\
\text { mesmos atletas. O trabalho que realizamos na } \\
\text { cobertura destes Jogos Olímpicos contava com } \\
\text { duas páginas diárias onde se publicavam todos } \\
\text { aqueles dados que consideramos relevantes a } \\
\text { nível da participação portuguesa, sempre com o } \\
\text { principal enfoque na participação dos atletas do } \\
\text { Minho, nosso principal alvo. }\end{array}$ & $\begin{array}{l}\text { Carlos Miguel Machado explica a necessidade da } \\
\text { cobertura regional a partir do âmbito de atuação do } \\
\text { jornal, a partir dos atletas minhotos (provenientes } \\
\text { da Região do Minho). A seção de esportes, durante } \\
\text { os Jogos Olímpicos, contou com duas páginas } \\
\text { dedicadas às notícias relacionadas à delegação } \\
\text { portuguesa durante os eventos. } \\
\text { O jornalista também enfatiza o fato de que as } \\
\text { Olimpíadas, a partir do prestígio em escala global } \\
\text { (internacional) atrai o interesse dos leitores e } \\
\text { justifica a demanda pela área temática na seção } \\
\text { esportiva nos Jogos para as edições diárias do } \\
\text { Correio do Minho. }\end{array}$ \\
\hline $\begin{array}{l}\text { Em termos de jornal, tínhamos duas páginas no } \\
\text { jornal e na [emissora de] rádio [Antena Minho], } \\
\text { dois programas diários. As nossas principais } \\
\text { fontes, para poder acessar as informações } \\
\text { daquilo que ia se passando no Brasil, foram } \\
\text { essencialmente: o site oficial dos Jogos } \\
\text { Olímpicos até para ter noção dos horários das } \\
\text { provas, de quando os nossos atletas iam } \\
\text { participar. Fizemos um agendamento para }\end{array}$ & $\begin{array}{l}\text { Além da publicação de notícias no Correio do } \\
\text { Minho, os jornalistas também tinham suas matérias } \\
\text { produzidas divulgadas pela rádio Antena Minho, } \\
\text { emissora do Grupo Arcada Nova, proprietário do } \\
\text { jornal. O jornalista destaca a manutenção do } \\
\text { agendamento para o acompanhamento dos atletas } \\
\text { minhotos nas competições das várias modalidades } \\
\text { em disputa nos Jogos do Rio de Janeiro em } 2016 \text {. } \\
\text { O acesso a fontes da web, como o site oficial das }\end{array}$ \\
\hline
\end{tabular}


acompanhar os diversos atletas das várias modalidades, porque tivemos muitos atletas em modalidades diferentes e a consulta que nós fazemos do site oficial era relacionado a isso: tentar fazer a agenda das provas e competições que nos interessava cobrir e estar atentos. Também usávamos o site oficial dos Jogos Olímpicos, essencialmente, para obter fotos oficiais das provas dos nossos atletas. Em termos de texto, tínhamos contatos diretos com alguns dos nossos atletas minhotos que participavam lá e fazíamos esse contato direto por telefone [...] nossa cobertura foi aqui no local [Braga], mas à distância, não tivemos nenhum jornalista credenciado, nem destacado para participar dos Jogos, porque não tínhamos capacidade financeira para fazer.

Dentro dos [assuntos sobre] atletas minhotos que participaram dos Jogos, tínhamos atletas de várias modalidades que estão muito enraizadas aqui na região e que cobrimos porque as pessoas também gostam dessas modalidades e [as] apreciam. Primeiramente, em nível de atletismo, tínhamos vários atletas minhotos e, também, no tênis, onde o atual tenista português, que é considerado como o melhor da atualidade é da região do Minho: o João Sousa é natural [da cidade] de Guimarães. E depois, uma outra modalidade muito forte em que há muito interesse dos nossos leitores e também ouvintes, é a canoagem, porque temos diversos atletas de currículo internacional muito forte e que também procuravam fazer história nestes Jogos Olímpicos. Depois, procuramos também, ao longo da competição, ir acompanhando os resultados considerados os mais importantes dos feitos que eram alcançados pelas equipes portuguesas, mas também íamos dando conta dos resultados obtidos por outros países, como os recordes mundiais e recordes olímpicos.
Olimpíadas. Além da internet, foram contatados os atletas da delegação portuguesa no Brasil por telefone.

Machado esclarece as limitações de se fazer uma cobertura à distância: o jornal Correio do Minho não possuía capacidade financeira para solicitar credenciamento para o envio de correspondentes para os locais dos Jogos.

Machado enfatiza que os atletas minhotos que participaram dos Jogos competiram em modalidades enraizadas na Região do Minho e que acabou por descobrir que os leitores têm interesse nas modalidades em questão, como o atletismo. Além disso, também tiveram enfoque o tênis, praticado por João Sousa, de Guimarães, e a canoagem, com esportistas com participações em torneios internacionais. Além da cobertura local e regional, Machado enfatiza a importância para os atletas nacionais e os destaques internacionais, a partir dos recordes olímpicos e mundiais.

Carlos Miguel Machado (2017) coloca em evidência a cobertura local e regional a partir da atuação do jornal Correio do Minho, que manteve, durante os Jogos Olímpicos, duas páginas temáticas sobre o evento com foco nos atletas locais e nos esportistas da delegação portuguesa no Rio de Janeiro. O jornalista revela que foi descoberto o interesse dos leitores por modalidades que tinham atletas locais em torneios internacionais e que estavam nos Jogos: atletismo, tênis e canoagem. Machado (2017) também destaca a utilização das matérias produzidas para o jornal na programação da Rádio Antena Minho que, assim como o Correio do Minho, faz parte do Grupo Arcada Nova. 
Devido à indisponibilidade financeira para o envio de correspondentes e credenciamento de jornalistas nos locais de competição, a cobertura das Olimpíadas foi realizada à distância, com destaque para o uso de fontes da internet e contatos telefônicos com os atletas da missão portuguesa no Rio. Além de a pauta privilegiar a abrangência regional, foram incluídos os âmbitos nacional, como os atletas portugueses de outras regiões, e internacional, a partir dos esportistas que obtiveram destaque em recordes mundiais e olímpicos.

Entrevistado: Carlos Flórido, editor do jornal $O$ Jogo PRIMEIRA QUESTÃO: A COBERTURA DOS JOGOS OLÍMPICOS DE 2016

\begin{tabular}{|c|c|}
\hline ENUNCIADO & DESCRIÇÃO ANALÍTICA \\
\hline $\begin{array}{l}\text { A minha primeira cobertura em terreno [in loco] } \\
\text { em Atlanta, em 1996. Essa foi a primeira em } \\
\text { que se usava a internet nos Jogos, mas essa } \\
\text { estava numa fase inicial e praticamente só era } \\
\text { útil para consultar o currículo dos atletas, para } \\
\text { saber o que haviam ganho antes e o resto do } \\
\text { trabalho era em papel. No Rio, foi a primeira } \\
\text { edição dos Jogos totalmente via internet e, } \\
\text { inclusive, foi aquela em que nos disseram no } \\
\text { começo das partidas: não iam dar os resultados } \\
\text { em papel, era tudo consultado online. Havia } \\
\text { impressoras, se quiséssemos imprimir algo ou } \\
\text { guardar alguma coisa. A consulta online } \\
\text { funcionava de dois modos: tínhamos o site } \\
\text { oficial dos Jogos, com aquilo que era } \\
\text { disponibilizado a todos, e um outro site, uma } \\
\text { intranet, só para jornalistas. Essa foi a nossa } \\
\text { melhor ferramenta: usávamos em tudo, era ali } \\
\text { que eu ia consultar os resultados. }\end{array}$ & $\begin{array}{l}\text { Carlos Flórido menciona um pouco de sua trajetória } \\
\text { na cobertura dos Jogos Olímpicos in loco desde } \\
\text { 1996, quando havia pouca utilização da internet e a } \\
\text { maior parte do trabalho dos repórteres era feita no } \\
\text { papel. Ele menciona o crescimento do meio digital } \\
\text { a ponto de se utilizar apenas a internet nos Jogos de } \\
2016 \text {, sem haver a divulgação de resultados em } \\
\text { papel. As fontes online disponibilizadas para os } \\
\text { jornalistas foram o site oficial dos Jogos Olímpicos } \\
\text { (a partir do IOC) e uma página interna (intranet) } \\
\text { destinada a jornalistas, cujo acesso ficava restrito } \\
\text { aos credenciados. Essa última foi considerada a } \\
\text { melhor por Flórido, devido à disponibilidade de } \\
\text { informações pontuais que iriam ser utilizadas na } \\
\text { produção das notícias. }\end{array}$ \\
\hline $\begin{array}{l}\text { Eu ia a uma prova e, como Portugal foi muito } \\
\text { importante em canoagem, cobria esse esporte. } \\
\text { Ia para o Centro de Imprensa sem saber sem } \\
\text { saber como tinha ficado aquele português, não } \\
\text { sabia o tempo dele e, lá via o tempo, fazia a } \\
\text { comparação com os outros, consultava os } \\
\text { currículos dos outros atletas e digamos, fazia } \\
\text { todo o meu trabalho dos Jogos com a internet. } \\
\text { Posso dizer que funcionou bem: houve alturas } \\
\text { que a rede era um pouco mais lenta, creio que } \\
\text { por excesso de utilização, isso é fatal e acontece } \\
\text { em todos os lados, mas funcionou muito bem - } \\
\text { foi um dos aspectos que o Brasil me } \\
\text { surpreendeu, porque mostrou um avanço e } \\
\text { também uma preocupação ecológica: foram os } \\
\text { primeiros Jogos Olímpicos em que realmente se } \\
\text { poupou muito papel no Centro de Imprensa; } \\
\text { houve muito pouca gente que imprimia papéis. } \\
\text { Praticamente quase todos usavam seus }\end{array}$ & $\begin{array}{l}\text { O jornalista menciona sua atuação na modalidade } \\
\text { da canoagem: ia às competições e depois retornava } \\
\text { ao Centro de Imprensa onde acessava as fontes da } \\
\text { internet para pesquisar sobre os tempos, } \\
\text { rendimentos, resultados e currículos dos atletas - ao } \\
\text { esclarecer que a utilização de fontes digitais havia } \\
\text { se tornado imprescindível para seu trabalho e que } \\
\text { os jornalistas iam usavam seus computadores. } \\
\text { Flórido diz ter ficado surpreso com o fato de o } \\
\text { Brasil justificar o excesso da utilização de mídias } \\
\text { digitais com o tema ecológico para economizar } \\
\text { papel, inclusive com poucos jornalistas utilizando } \\
\text { impressoras. Como um usuário-interator, Flórido } \\
\text { disse ter percebido momentos de lentidão no acesso } \\
\text { aos sites de modo compreensível em que vários } \\
\text { jornalistas poderiam ter sobrecarregado a rede sem } \\
\text { comprometer o acesso. }\end{array}$ \\
\hline
\end{tabular}


computadores, faziam as consultas e escreviam diretamente.

Os Jogos, no Brasil, em vários aspectos foram bons, melhores do que nós pensávamos. Quando um jornalista vai cobrir os Jogos, há vários aspectos que são fundamentais: a rede de transportes, que no Brasil funcionou bem. Esse era um aspecto que tínhamos medo por causa de tudo que se dizia do Brasil... E eu, que já tinha feito vários Jogos Olímpicos, pensei logo: vou demorar horas para chegar qualquer local, mas não. A rede de transportes funcionou bem quase todos os dias: não foi perfeita, mas foi funcional. $\mathrm{O}$ acesso às zonas de competições foi rápido e, nos primeiros dias não foi e esse é um dos maiores elogios que tivemos que fazer ao Brasil, porque quando chegamos lá, havia filas enormes para todos os lados, tudo estava funcionando muito mal; mas o Brasil soube se adaptar durante os Jogos, colocou mais portas de entrada para a revista de jornalistas, soube fazer esse processo ficar mais rápido. $\mathrm{E}$ foi a primeira vez, nos Jogos Olímpicos, que vi seguranças simpáticos... Parece que não é importante e eu explico: nos Estados Unidos [Atlanta], se o jornalista quisesse ir à rua para fumar um cigarro: levava cerca de 20 a 30 minutos na fila para voltar a entrar no Centro de Imprensa, mas imagina, a cada cigarro que o jornalista fumava, tinha que esperar 20 a 30 minutos para voltar a entrar no Centro de Imprensa porque ele precisava ser revistado, apesar de ter uma área interna para fumantes.

O conteúdo utilizado pelos jornalistas varia em função do jornalista, ou seja, a organização [dos Jogos] tem que disponibilizar tudo porque não sabe o que o jornalista quer. No meu caso, do jornal $O$ Jogo, o fundamental era ter os resultados mais completos, detalhes que não aparecem nas notícias, por exemplo, o que um maratonista fez a cada $5 \mathrm{~km}$ do percurso para poder comparar e perceber se o atleta fez uma prova correta ou se andou muito no início e estava cansado no final, ou andou pouco no início e se atrasou no final. Todos esses dados fazem parte do nosso trabalho e isso era disponibilizado. A internet é um avanço nesse aspecto, porque é muito mais fácil ter esse tipo de informação e no papel, devemos usar mais papel para ter mais tipos de informação. Para mim, tudo isso bastou: ter resultados com todos os dados sobre a prova e, na canoagem, eu precisava saber o que um atleta fez aos $100 \mathrm{~m}$, $250 \mathrm{~m}, 500 \mathrm{~m}$ e $750 \mathrm{~m}$, além de saber qual era o ritmo da pagaiada [remada com o pagaio] e isso
Flórido revela ter ficado surpreso com a infraestrutura que o Brasil ofereceu aos jornalistas, como o transporte público que, de modo geral, funcionou a ponto de não comprometer a chegada dos jornalistas aos locais de provas. Também elogiou a forma como a organização dos Jogos se adaptou para otimizar o tempo na entrada dos locais e do processo de revista de jornalistas, com a colocação de mais portas de entrada a ponto de tornar o acesso dos profissionais da imprensa mais rápido.

O jornalista ressalta como ponto positivo o fato de os locais de competição terem seguranças simpáticos, porque, no caso do jornalista ter que sair dos locais, não havia a necessidade de voltar à fila de acesso e revista. Segundo ele, cada saída demorava até 30 minutos para que o jornalista voltasse aos locais das provas.

Flórido destaca a utilização de informações úteis para o jornalista durante a cobertura de competições, como os detalhes no acompanhamento, parte por parte a fim de se ter informações suficientes a fim de produzir análises mais detalhadas sobre disposição e cansaço de atletas (rendimento). Para o processo de levar conteúdos diferenciados aos leitores, além da divulgação de resultados, a forma com que a seção reservada do site do Comitê Olímpico Internacional aos jornalistas fornecia esse tipo de informação não muito detalhada em outros sítios, mas também pelas agências de notícias portuguesas ou mesmo pelo próprio atleta.

Em determinados casos, o jornalista menciona alguns momentos particulares de atletas na Vila Olímpica, como no refeitório ou na companhia de amigos. De certo modo, os sites dos comitês olímpicos (do Brasil e de Portugal) oferecem vídeos que retratam tais temas além das competições. O jornalista menciona a importância 
era importante, porque com isso se vê se o atleta está ou não cansado, se está atacando ou se defendendo, a velocidade do barco... Tudo isso é medido e disponibilizado e permite fazer uma crônica mais completa. Eu trabalho num jornal e só precisava disso, porque eu tenho uma agência que me passa fotografias e quando muito, irei precisar das imagens dos atletas do meu país, mas isso já não é um site do Comitê que me dá, é a organização do país ou o próprio atleta. Neste momento, passou a ser importante para as pessoas ter, por exemplo, uma fotografia do atleta na Vila Olímpica com os amigos, quando o atleta foi ao refeitório comer alguma coisa. Todo esse lado é curioso e o público gosta de ver isso, mas isso já não tem a ver com o Comitê. Há jornalistas que usam fotografias ou vídeos do Comitê. O próprio jornal O Jogo usa vídeos do Comitê, mas aí não é com os enviados, mas com quem ficou na redação, que vai consultar o site dos Jogos e vai procurar lá os conteúdos e, quem estava no local vai procurar fotografias e vídeos, porque a internet vive muito dos vídeos que são disponibilizados. Posso dizer que no caso dos Jogos do Rio [de Janeiro], praticamente estava tudo disponível, não tivemos queixas. de se utilizar essas fontes na redação, mas não para o jornalista que acompanhava os eventos in loco.

Carlos Flórido (2017) faz vários destaques à forma como a cobertura das Olimpíadas de 2016 foi realizada: utilização majoritária de fontes da internet, trabalho com o computador e pouco uso de papel. Entre as fontes, ele destaca a recorrência à página online dos Jogos Olímpicos mantida pelo IOC e à rede de acesso restrito a jornalistas credenciados, com a disponibilização de dados específicos para a produção de notícias.

O profissional diz ter ficado surpreso com o Brasil a partir da forma como os acessos de jornalistas aos locais de competição foram adaptados, tornando o processo mais rápido, principalmente em momentos em que havia necessidade de o jornalista sair e voltar aos lugares. A respeito das qualificações, Flórido (2017) ressalta a forma como a página restrita aos jornalistas credenciados disponibilizava dados referentes às competições, a fim de proporcionar uma análise mais precisa sobre o rendimento dos atletas.

O português também menciona a importância do material publicado pelos comitês olímpicos de Portugal e do Brasil, com fotografias e vídeos de atletas em momentos descontraídos, na companhia de amigos ou no refeitório. Ele avalia que essa informação tinha importância para os jornalistas que ficaram nas redações porque os leitores também buscam esse perfil nas notícias. Flórido (2017) destaca ainda que o jornalista, ao cobrir in 
loco, deve buscar informações específicas a fim de produzir análises mais precisas sobre a partida que acompanha.

Entrevistado: Fernando Eurico, locutor esportivo da Rádio Antena 1 e do canal de TV RTP PRIMEIRA QUESTÃO: A COBERTURA DOS JOGOS OLÍMPICOS DE 2016

\begin{tabular}{|c|c|}
\hline ENUNCIADO & DESCRIÇÃO ANALÍTICA \\
\hline $\begin{array}{l}\text { Através de minha rádio, apenas levamos dois } \\
\text { jornalistas, eu e um outro colega de Lisboa, que } \\
\text { tínhamos como princípio básico fazer a } \\
\text { cobertura humanamente possível de toda a } \\
\text { delegação portuguesa. Então fomos para o } \\
\text { Brasil, no Rio de Janeiro, uns dias antes do } \\
\text { início da competição, no fundo para ver alguma } \\
\text { ambientação pessoal, para conhecermos todo o } \\
\text { Parque Olímpico, a cidade, os transportes e tudo } \\
\text { que iria interferir com o nosso e também, com a } \\
\text { atividade dos próprios atletas e da delegação } \\
\text { portuguesa. Frequentamos muito a Aldeia } \\
\text { Olímpica, onde nossos atletas estavam } \\
\text { concentrados e, quando a competição começou, } \\
\text { tivemos um problema de não podermos fazer a } \\
\text { cobertura de todos os eventos e todos os atletas } \\
\text { portugueses, porque isso era humanamente } \\
\text { impossível. }\end{array}$ & $\begin{array}{l}\text { Fernando Eurico menciona detalhes da limitação de } \\
\text { duas equipes na cobertura dos Jogos diante da } \\
\text { quantidade de competições que envolviam os } \\
\text { atletas portugueses no Rio de Janeiro. Foi } \\
\text { mencionada a importância de chegar antes do início } \\
\text { das competições e de se ambientar: conhecer os } \\
\text { locais e as infraestruturas que viessem a interferir } \\
\text { em seu trabalho, além de frequentar as } \\
\text { dependências da Vila Olímpica, local onde os } \\
\text { atletas da missão portuguesa estavam } \\
\text { concentrados. }\end{array}$ \\
\hline $\begin{array}{l}\text { Tivemos que fazer, a cada dia, um rastreamento, } \\
\text { uma escolha daqueles que considerávamos mais } \\
\text { importantes, digamos, um critério atribuído que } \\
\text { passaria pela importância dos atletas: há atletas } \\
\text { que são mais conhecidos que outros e, também, } \\
\text { a possibilidade de um bom resultado, um } \\
\text { recorde nacional ou, por exemplo, de uma } \\
\text { passagem a uma final, a discussão das } \\
\text { medalhas. Portanto, era assim que íamos } \\
\text { fazendo essa atribuição e, sempre que havia } \\
\text { tempo restante, produzíamos reportagens sobre } \\
\text { a cidade, sobre o povo carioca, o brasileiro e os } \\
\text { esportes brasileiros e também sobre os atletas } \\
\text { mais conhecidos mundialmente. Para dar um } \\
\text { exemplo, tentei fazer um trabalho e consegui } \\
\text { com a Serena Williams do tênis; tentamos } \\
\text { também com alguns tenistas e não foi possível; } \\
\text { com alguns velejadores, fizemos um trabalho } \\
\text { com mítico velejador brasileiro Robert Scheidt. } \\
\text { Portanto, esse foi basicamente o trabalho que } \\
\text { fizemos. }\end{array}$ & $\begin{array}{l}\text { O jornalista pondera a necessidade de escolher } \\
\text { cobrir determinados eventos e prescindir de outros. } \\
\text { Para esse caso, foi utilizado o critério de dar } \\
\text { importância a atletas e equipes mais conhecidos e } \\
\text { acompanhar destaques, como recordes nacionais, } \\
\text { além de discutir as medalhas. } \\
\text { Quando restava algum tempo, as duas equipes } \\
\text { produziam reportagens sobre a cidade, o povo } \\
\text { carioca, o brasileiro e os esportes brasileiros, além } \\
\text { de especiais com atletas conhecidos mundialmente, } \\
\text { como a tenista norte-americana Serena Williams e } \\
\text { o velejador brasileiro Robert Scheidt. }\end{array}$ \\
\hline
\end{tabular}

Fernando Eurico (2017) descreve a forma como procurou se ambientar com as instalações dos Jogos Olímpicos do Rio de Janeiro: conhecer o local e a infraestrutura, como meios de transporte e a Vila Olímpica, onde os atletas circulavam. 
Eurico destaca a limitação de contar com duas equipes para cobrir as competições com os atletas portugueses e que, apesar dos direitos de transmissão, havia necessidade de as emissoras não gastarem muito dinheiro, o que teve reflexo no tamanho das delegações que cobriram os Jogos in loco. Diante disso, foram escolhidos a transmissão de competições com atletas conhecidos e o destaque de recordes nacionais.

Segundo Eurico (2017), se houvesse tempo, as equipes produziam matérias especiais sobre a cidade do Rio de Janeiro, o povo carioca, os esportes brasileiros e entrevistas com esportistas de renome internacional. A tenista norte-americana Serena Williams e o velejador brasileiro Robert Scheidt foram personalidades com quem as equipes conseguiram produzir reportagens.

Entrevistado: Pedro Jorge da Cunha, editor do site Maisfutebol PRIMEIRA QUESTÃO: A COBERTURA DOS JOGOS OLÍMPICOS DE 2016

\begin{tabular}{|c|c|}
\hline ENUNCIADO & DESCRIÇÃO ANALÍTICA \\
\hline $\begin{array}{l}\text { Eu parti daqui, de Portugal, com uma série de } \\
\text { ideias, cerca de } 25 \text { a } 30 \text { ideias para fazer matéria } \\
\text { diferente, que fugiam um pouco do âmbito das } \\
\text { competições e de tudo que rodeava a } \\
\text { organização. Por exemplo, algo que estava } \\
\text { completamente fora da caixa e que nós } \\
\text { aproveitamos: fomos à casa do Mané } \\
\text { Garrincha, em Pau Grande, que é perto do Rio, } \\
\text { fomos ao cemitério onde ele está sepultado, } \\
\text { porque entendemos que a proximidade } \\
\text { justificava essa visita, até por ser uma } \\
\text { personagem um pouco mítica aqui para os } \\
\text { portugueses. }\end{array}$ & $\begin{array}{l}\text { Pedro Jorge da Cunha revela a importância de ter } \\
\text { saído de Portugal para cobrir os Jogos com várias } \\
\text { ideias sobre pautas. O objetivo era produzir } \\
\text { materiais diferenciados das discussões sobre } \\
\text { competições e da organização, a fim de conciliar a } \\
\text { cobertura dos Jogos Olímpicos com a produção de } \\
\text { reportagens especiais em locais próximos ao Rio de } \\
\text { Janeiro. Ele destaca a visita à casa do jogador de } \\
\text { futebol Mané Garrincha e a locais que aparecem na } \\
\text { biografia do emblemático atleta. }\end{array}$ \\
\hline $\begin{array}{l}\text { No dia a dia, acompanhamos essencialmente as } \\
\text { provas dos atletas portugueses, os favoritos, } \\
\text { onde nós julgávamos que poderia haver um } \\
\text { resultado interessante e depois, obviamente, } \\
\text { também muito foco naquelas figuras de } \\
\text { dimensão e imediatismo mundial: Michael } \\
\text { Phelps, Rafael Nadal, a equipe de basquete dos } \\
\text { Estados Unidos, por terem atletas da NBA. } \\
\text { Tentamos acompanhar mais essas equipes de } \\
\text { foco midiático muito forte aqui em Portugal. } \\
\text { Estava sozinho lá, pelo Maisfutebol, e tive um } \\
\text { grande apoio daqui da redação a partir de } \\
\text { Portugal e fizemos um trabalho bastante } \\
\text { louvável. }\end{array}$ & $\begin{array}{l}\text { O jornalista aborda a rotina de seu trabalho durante } \\
\text { a cobertura dos Jogos no Rio de Janeiro em 2016: } \\
\text { acompanhar os atletas portugueses favoritos a } \\
\text { partir da expectativa de resultados exitosos e depois } \\
\text { as figuras de dimensão e imediatismo mundial, } \\
\text { como o nadador Michael Phelps, o tenista Rafael } \\
\text { Nadal e a equipe de basquete dos Estados Unidos, } \\
\text { com os jogadores da NBA. } \\
\text { Cunha fez a cobertura in loco sozinho, mas contou } \\
\text { com a ajuda das redações em Portugal, da sucursal } \\
\text { em Porto e de outros jornalistas do grupo Media } \\
\text { Capital. }\end{array}$ \\
\hline
\end{tabular}

Pedro Jorge da Cunha (2017) destaca aspectos importantes da cobertura dos Jogos Olímpicos. O jornalista foi para o Rio de Janeiro com várias ideias de pauta para produzir materiais especiais além das competições, como a visita à cidade onde nasceu o jogador de futebol Mané Garrincha. 
Como critério de prioridade para as notícias produzidas in loco, Cunha (2017) optou pelo foco em atletas portugueses mais conhecidos e favoritos a medalhas, além de abordar as expressões de renome internacional nos esportes olímpicos, como o nadador Michael Phelps, o tenista Rafael Nadal e a equipe de basquete dos Estados Unidos. O trabalho de cobertura teve ajuda de jornalistas da redação do site Maisfutebol, no Porto, e do IOL, um dos importantes sítios generalistas de Portugal, controlado pelo grupo Media Capital.

\subsubsection{Utilização do site do COB como fonte no jornalismo português}

Essa seção tem como foco principal de abordagem a utilização do site do COB por jornalistas portugueses. A partir desse panorama, esse sítio da web não aparece como uma possibilidade da cobertura local, uma vez que as reportagens internacionais terão como base os eventos e os atletas da delegação portuguesa.

$\mathrm{O}$ site do $\mathrm{COB}$, nesse caso, emerge como uma fonte de notícias provenientes do paíssede, o Brasil. A aplicação dessa pergunta tem a finalidade de buscar nuances em relação a utilização dessa ferramenta da web pelos jornalistas de Portugal durante os Jogos ocorridos no Rio de Janeiro.

Entrevistado: Daniel Vieira da Silva, diretor da Rádio Universitária do Minho SEGUNDA QUESTÃO: UTILIZOU ALGUM CONTEÚDO DO SITE DO COB? QUAL FOI O CONTEÚDO UTILIZADO?

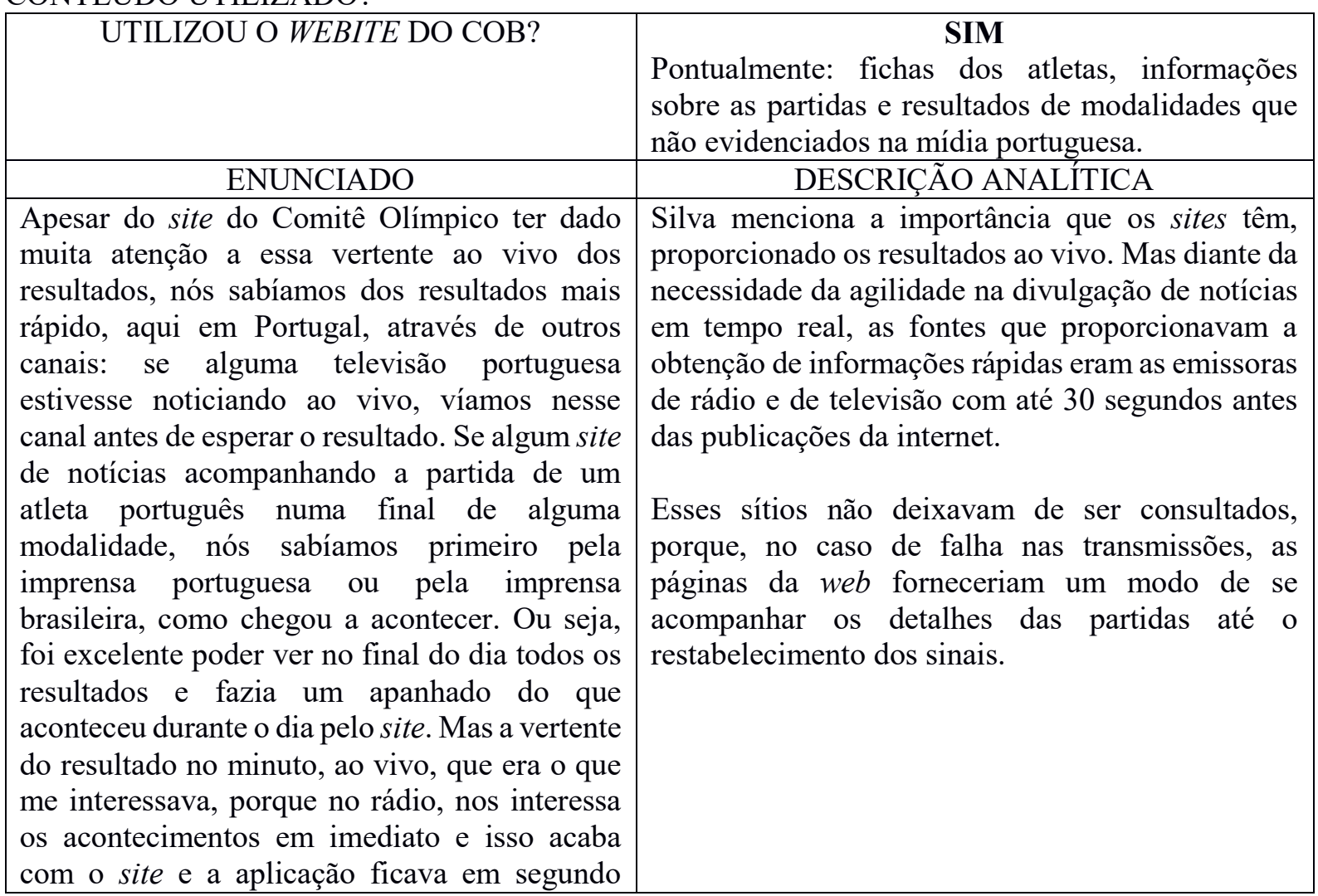


plano porque falhava, mas aqui falamos de questões de 20 ou 30 segundos.

No que diz respeito à disponibilização das fichas dos atletas, dos horários das competições, o site estava muito bem construído, se vale de uma forma muito clara e, sempre que eu queria uma informação das Olimpíadas, a minha primeira fonte de informação era o site. Se queria algo mais aprofundado sobre algum atleta, alguma história pessoal; como é lógico, o site oficial não tem que ter isso e eu iria buscar outras fontes de informação mais específica: de acordo com a proveniência do atleta, com a modalidade. Mas o site foi, sim, efetivamente, uma fonte de informação muito importante para nós.

O jornalista destaca o uso de fichas com as informações dos atletas e dos horários das competições. Também há uma clara menção à construção do site, interpretado como carregamento rápido na tela de dispositivos e da legibilidade dos conteúdos. Além disso, ele enfatiza a necessidade de contar com a informação do COB para os Jogos Olímpicos e principalmente, como fonte de informação para os jornalistas da Rádio Universitária do Minho. Entretanto, não supria alguns aspectos exigidos a partir das pautas esportivas: informações específicas de atletas e de modalidades.

Silva (2017) considera o site do COB uma importante fonte de informação para os jornalistas da Rádio Universitária do Minho. Entretanto, não supria alguns aspectos das pautas esportivas, como acompanhamento em tempo real, a fim de que a emissora viesse a divulgar notícias no ar.

Nesses casos, foram mais úteis as escutas provenientes de outras emissoras de rádio e televisão, com uma antecedência de até 30 segundos antes das atualizações publicadas no site. Ele diz que, apesar do atraso, tais páginas não deixavam de ser acompanhadas, pois, em caso de falha de sinal, a informação proveniente da web teria maior importância durante o acompanhamento das competições.

Entrevistado: Carlos Miguel Machado, repórter do jornal Correio do Minho SEGUNDA QUESTÃO: UTILIZOU ALGUM CONTEÚDO DO SITE DO COB? QUAL FOI O CONTEÚDO UTILIZADO?

\begin{tabular}{|c|c|}
\hline UTILIZOU O SITE DO COB? & $\begin{array}{l}\text { SIM } \\
\text { Regularmente: resultados; notificação de notícias } \\
\text { por } e \text {-mail e fotografias dos eventos. }\end{array}$ \\
\hline ENUNCIADO & DESCRIÇÃO ANALÍTICA \\
\hline $\begin{array}{l}\text { Portanto, as nossas principais fontes para a } \\
\text { cobertura dos Jogos Olímpicos no Rio em } 2016 \\
\text { foram alguns contatos diretos com os atletas e a } \\
\text { cobertura por intermédio de agências. } \\
\text { Diariamente, em Portugal, recorríamos à } \\
\text { Agência Lusa, que é uma agência que tinha } \\
\text { vários jornalistas fazendo a cobertura da } \\
\text { competição e também recorríamos ao site } \\
\text { oficial do Comitê dos Jogos Olímpicos, também } \\
\text { através de sua página na rede social Facebook, } \\
\text { onde acompanhávamos a colocação dos } \\
\text { resultados registrados nas várias competições e } \\
\text { também usávamos esse e-mail oficial para obter } \\
\text { algumas fotos para depois ilustrarmos os nossos } \\
\text { trabalhos que íamos publicando diariamente. }\end{array}$ & $\begin{array}{l}\text { Machado aborda a utilização do site do COM entre } \\
\text { as principais fontes de informação dos jornalistas } \\
\text { esportivos do Correio do Minho, além da Agência } \\
\text { Lusa, com prioridade a notícias de portugueses. } \\
\text { Dentre os acessados estavam os sites dos Jogos } \\
\text { Olímpicos (do IOC), do COB e as páginas do } \\
\text { Facebook para contatos com atletas locais e com } \\
\text { ênfase na cobertura da delegação portuguesa. A } \\
\text { partir da notificação da publicação de notícias por } \\
\text { e-mail, o conteúdo referenciado também contaria } \\
\text { com a utilização de fotografias provenientes dessas } \\
\text { fontes. }\end{array}$ \\
\hline
\end{tabular}


Como disse, somos um jornal local e regional, sem capacidade financeira para poder enviar um jornalista que pudesse, durante aquele mês [agosto de 2016], fazer a cobertura e, mesmo assim, não deixamos de fazer a cobertura, mas recorrendo às agências e a toda a informação por meio da internet, usando as fontes oficiais dos Jogos, nomeadamente do Comitê Olímpico, porque consideramos que era a ferramenta oficial de mais credibilidade para fazer a nossa cobertura. Também, porque tínhamos muitos atletas do Minho participando, fazíamos alguns contatos pessoais através das redes sociais, principalmente pelo Facebook, onde tivemos reações [deles], e quando estavam participando [das provas,] o que estavam sentindo ou quando iam competir nas várias provas - por meio dessas ferramentas: a internet como principal fonte, sempre recorrendo à Agência Lusa e aos contatos pessoais com os atletas por meio do Facebook.
O jornalista salienta o fato do jornal em que atua ter dimensões local e regional, bem como a limitação financeira para o envio de correspondentes credenciados aos locais dos Jogos Olímpicos no Brasil. Para a realização da cobertura à distância, os jornalistas esportivos do Correio do Minho utilizaram a informação proveniente de agências, de fontes oficiais e de contatos com os atletas da Região do Minho pelas redes sociais.

Machado (2017) aborda a utilização do site do $\mathrm{COM}^{42}$ entre as principais fontes de informação dos jornalistas esportivos do Correio do Minho, além da Agência Lusa, com prioridade para as notícias de portugueses. Também foram acessados o sítio oficial dos Jogos Olímpicos (do IOC), a página do COB e a rede social Facebook, com ênfase nos atletas regionais e na delegação lusitana. A partir da notificação da publicação de notícias por $e$ mail, o conteúdo referenciado contou com a utilização de fotografias provenientes dessas fontes para a ilustração das notícias publicadas no jornal.

O profissional salienta a abrangência local e regional do jornal, bem como a limitação financeira para o envio de correspondentes credenciados ao Brasil. Para a realização da cobertura à distância, os jornalistas esportivos do Correio do Minho utilizaram a informação das seguintes fontes: agências, fontes oficiais e contato com atletas da região do Minho via redes sociais.

Entrevistado: Carlos Flórido, editor do jornal O Jogo SEGUNDA QUESTÃO: UTILIZOU ALGUM CONTEÚDO DO SITE DO COB? QUAL FOI O CONTEÚDO UTILIZADO?

\begin{tabular}{|c|c|}
\hline UTILIZOU O SITE DO COB? & $\begin{array}{l}\text { SIM } \\
\text { Esporadicamente: fichas dos atletas; por } \\
\text { curiosidade: impressões do que os brasileiros } \\
\text { pensam sobre os portugueses. }\end{array}$ \\
\hline ENUNCIADO & DESCRIÇÃO ANALÍTICA \\
\hline $\begin{array}{l}\text { Se tem enviados especiais para os Jogos } \\
\text { Olímpicos, podem ser } 3 \text { ou } 4 \text {, mas também tem } \\
\text { uma retaguarda que fica na redação: essa } \\
\text { retaguarda é responsável por muitas das } \\
\text { consultas e é responsável por todo o resto dos }\end{array}$ & $\begin{array}{l}\text { Flórido põe em evidência o trabalho dos jornalistas } \\
\text { na redação como essencial à consulta de fontes. Em } \\
\text { meio à necessidade da cobertura da delegação } \\
\text { portuguesa, o jornalista também reforça a } \\
\text { diminuição da recorrência ao site do COB. Desse }\end{array}$ \\
\hline
\end{tabular}

${ }^{42}$ Comitê Organizador dos Jogos Olímpicos e Paralímpicos Rio 2016. É vinculado ao IOC. 
Jogos. E, se estamos falando dos Jogos Olímpicos, há uma contribuição importante, mas não é tudo porque, quando um jornalista está nos Jogos, está preocupado, sobretudo, com o seu país: tem que dar informações dos seus atletas.

Aquilo que o Brasil me forneceu foi importante para os portugueses, por isso, tinham todos esses dados, tinham todos esses resultados e tinha, inclusive, aquilo que Portugal nos dava: informações sobre os seus atletas - o que eles tinham e não tinham feito, mas eu tanto poderia consultar o que me dava [de informação] o Comitê do meu país, como poderia consultar o Comitê Olímpico [do Brasil], que era igual. Por vezes, era até interessante consultar a página do Comitê Olímpico [COB] porque eu podia saber o que os brasileiros pensavam dos portugueses. Por outro lado, o jornalista também não se limita a essas duas fontes de informação: o jornalista consulta um pouco de tudo. Se quiser saber um pouco do Phelps, vou consultar também os jornais americanos, essa é uma das grandes vantagens da internet.

Posso dizer que, no caso dos Jogos do Rio, praticamente estava tudo disponível, não tivemos queixas. Além disso, cabe à organização ter uma preocupação se o site está muito pesado ou não porque, quando eu carregar e se tiver dificuldade ao abrir, isso é importante: não posso esperar uns três minutos esperando o site abrir ou exibir um vídeo. $\mathrm{Eu}$ tenho que ir lá e tudo deve funcionar de imediato. Se não funciona imediatamente, não me serve, tenho que ir a outro. modo, as notícias sobre os competidores confederados da missão brasileira tornaram-se irrelevante nas pautas referentes aos esportistas nacionais (portugueses).

O jornalista menciona a consulta a um conteúdo específico do site do $\mathrm{COB}$, como a divulgação de resultados e informações das competições a serem realizadas. Além disso, o quesito da curiosidade havia sido evidenciado sobretudo, como forma de saber, por meio de um veículo oficial, sobre o que os brasileiros pensavam acerca da missão portuguesa. $O$ jornalista também enfatiza a necessidade de contar com várias outras fontes especializadas, como o acesso às publicações da imprensa dos países dos atletas favoritos em âmbito internacional - uma das grandes vantagens da internet.

Flórido (2017) evidencia o trabalho dos jornalistas da redação na consulta de fontes. Diante da necessidade da cobertura da delegação portuguesa, ele também reforça a diminuição da recorrência à página do COB. Desse modo, as notícias sobre os competidores confederados da missão brasileira tornaram-se irrelevantes nas pautas referentes aos esportistas de Portugal.

O jornalista menciona a consulta a um conteúdo específico do site do COB como meio de obtenção de resultados e informações das competições a serem realizadas. Além disso, por curiosidade, consultou o veículo oficial em busca de informações sobre o que os brasileiros pensavam acerca da missão portuguesa.

Flórido (2017) enfatiza a necessidade de se contar com várias outras fontes especializadas, como o acesso às publicações da imprensa dos países dos atletas favoritos 
em âmbito internacional - uma das grandes vantagens da internet. A partir da questão da usabilidade, cabe às instituições a preocupação em torno do carregamento e abertura das páginas da web, diante da necessidade de o repórter não contar com tempo na espera da exibição de conteúdo: um funcionamento útil deve acontecer imediatamente, senão outra fonte terá prioridade na consulta.

Entrevistado: Fernando Eurico, locutor esportivo da Rádio Antena 1 e do canal de TV RTP SEGUNDA QUESTÃO: UTILIZOU ALGUM CONTEÚDO DO SITE DO COB? QUAL FOI O CONTEÚDO UTILIZADO?

\begin{tabular}{|c|c|}
\hline \multirow{2}{*}{ UTILOZOU O SITE DO COB? } & SIM \\
\hline & $\begin{array}{l}\text { Pessoalmente sim: por curiosidade. } \\
\text { Profissionalmente } n \tilde{a} o \text { : foi utilizado o site do IOC } \\
\text { para jornalistas credenciados. }\end{array}$ \\
\hline ENUNCIADO & DESCRIÇÃO ANALÍTICA \\
\hline $\begin{array}{l}\text { A rigor, foi só por curiosidade que consultei o } \\
\text { site do Comitê Olímpico do Brasil, porque a } \\
\text { própria organização dos Jogos Olímpicos } \\
\text { disponibiliza um megassite, com todas as } \\
\text { delegações, incluindo a brasileira, onde } \\
\text { tínhamos as informações desde os horários das } \\
\text { competições, desde a biografia de cada atleta, } \\
\text { explicações das regras das modalidades. Enfim, } \\
\text { era um manancial de informação que não } \\
\text { citamos a partir daí, individualmente a cada } \\
\text { sítio em busca de informação. Também, pelas } \\
\text { características da cobertura, o nosso foco era } \\
\text { essencialmente a delegação portuguesa, e como } \\
\text { disse, acessei o site [do COB] apenas por } \\
\text { curiosidade. A rigor, também não retirei } \\
\text { qualquer informação importante ou que tivesse } \\
\text { sido fundamental para a organização e para a } \\
\text { produção do meu trabalho. }\end{array}$ & $\begin{array}{l}\text { Eurico expõe dois perfis diferentes quanto à } \\
\text { consulta do site do Comitê Olímpico do Brasil: para } \\
\text { o trabalho de cobertura nas transmissões das } \\
\text { partidas com atletas portugueses, a página de } \\
\text { intranet do IOC aparece como a principal fonte } \\
\text { utilizada. Entre as características, havia facilidade } \\
\text { no acesso às informações pontuais para o } \\
\text { acompanhamento dos Jogos, como horário das } \\
\text { provas, biografias de atletas de qualquer delegação } \\
\text { e explicação das regras das modalidades em } \\
\text { competição. O jornalista considera a disposição } \\
\text { desses dados como um manancial em meio as } \\
\text { fontes de notícias. } \\
\text { Entretanto, o jornalista português acessou a página } \\
\text { online do COB por curiosidade e, por causa de o } \\
\text { enfoque se concentrar na delegação portuguesa, o } \\
\text { principal conteúdo, Time Brasil, não teve } \\
\text { relevância para o trabalho nas emissoras de rádio e } \\
\text { televisão. }\end{array}$ \\
\hline $\begin{array}{l}\text { Ter o credenciamento por meio dos direitos, } \\
\text { uma vantagem que minha empresa [RTP] tem } \\
\text { como detentores dos direitos de transmissão, } \\
\text { para nós era um sossego porque poderíamos } \\
\text { entrar em todo o tipo de instalações, poderíamos } \\
\text { fazer transmissão ao vivo a partir de qualquer } \\
\text { local com um simples telemóvel [celular], coisa } \\
\text { que estava proibida a quem não tem esses } \\
\text { direitos. Essa [direitos de transmissão] tem sido }\end{array}$ & $\begin{array}{l}\text { Além de mencionar a fonte disponibilizada para os } \\
\text { jornalistas credenciados, Eurico explica as } \\
\text { vantagens de contar com os direitos de transmissão } \\
\text { e como isso reflete em seu trabalho. Nesse caso, o } \\
\text { jornalista pondera que nem sempre pôde contar } \\
\text { com esse tipo de acreditação e, no caso de preparar } \\
\text { materiais audiovisuais, a preocupação em utilizar } \\
\text { telefones celulares passa a inexistir. }\end{array}$ \\
\hline $\begin{array}{l}\text { uma tradição ao longo dos tempos porque nem } \\
\text { sempre minha rádio tem capacidade financeira } \\
\text { [...] em termos de Jogos Olímpicos é um } \\
\text { sossego para o repórter saber que pode emitir e } \\
\text { produzir de qualquer local sem ter problemas } \\
\text { com a segurança, com a organização e } \\
\text { sobretudo. A visibilidade do nosso trabalho e o } \\
\text { rendimento é outro, do que entrevistar um }\end{array}$ & $\begin{array}{l}\text { Com relação à cobertura sem os direitos de } \\
\text { transmissão, o jornalista expõe os impactos das } \\
\text { limitações, como a frustração de não poder gravar } \\
\text { depoimentos com atletas premiados ainda que esses } \\
\text { estejam na frente do repórter. Ele conclui sua } \\
\text { opinião para esse caso como uma forma do trabalho } \\
\text { do jornalista brilhar mais. }\end{array}$ \\
\hline
\end{tabular}


jogador na entrada da Aldeia Olímpica, não poder ver os acontecimentos de um atleta que acaba de ganhar uma medalha... Isso, na pele de um jornalista, é super frustrante. Portanto, ter a possibilidade de ter direitos de transmissão, como nós tivemos, é excelente. [...] basicamente, tendo os direitos, o trabalho tem mais brilho.

Profissionalmente, Eurico (2017) não recorreu ao site do COB para seu trabalho de cobertura das partidas envolvendo atletas portugueses. A página de intranet do IOC apareceu como a principal fonte, por conta da facilidade no acesso a informações pontuais para o acompanhamento dos Jogos, como horário das provas, biografia de atletas de qualquer delegação e explicação das regras das modalidades em competição.

No âmbito pessoal, o jornalista afirma ter acessado a página do COB por curiosidade. Como seu foco era a delegação portuguesa, o principal conteúdo do sítio do $\mathrm{COB}$, Time Brasil, não teve relevância para seu trabalho nas emissoras de rádio e televisão.

Eurico (2017) aparece como o único entrevistado que menciona detalhes de como os direitos de transmissão impactaram seu trabalho. Nesse caso, o jornalista pondera que nem sempre contou com esse tipo de credenciamento. Ao fazer a cobertura sem os direitos de transmissão, o profissional encara as limitações exemplificadas pela frustração de não poder gravar depoimentos com atletas premiados, ainda que eles estejam na frente do repórter. Ele conclui afirmando que um jornalista e uma empresa com credenciais fazem um trabalho com "mais brilho".

Entrevistado: Pedro Jorge da Cunha, editor do site Maisfutebol SEGUNDA QUESTÃO: UTILIZOU ALGUM CONTEÚDO DO SITE DO COB? QUAL FOI O CONTEÚDO UTILIZADO?

\begin{tabular}{|c|c|}
\hline UTILOZOU O SITE DO COB? & $\begin{array}{l}\text { SIM } \\
\text { Bastante: informações das partidas e inspiração de } \\
\text { pauta para a produção de notícias. }\end{array}$ \\
\hline ENUNCIADO & DESCRIÇÃO ANALÍTICA \\
\hline $\begin{array}{l}\text { Utilizei bastante: tanto do Rio [site oficial] } \\
\text { como do COB. O site do COB, consultei } \\
\text { diariamente, antes de fazer a viagem para lá, } \\
\text { para me preparar e depois, mesmo lá, porque, } \\
\text { nas Olimpíadas, a informação está tão dispersa, } \\
\text { é tão avassaladora que nós temos que tentar } \\
\text { focar um pouco e, com esses dois sites - Rio } \\
2016 \text { e do Comitê Olímpico do Brasil - } \\
\text { consegui fazer esse foco. }\end{array}$ & $\begin{array}{l}\text { Cunha menciona a utilização do site do COB } \\
\text { diariamente como forma de se manter informado } \\
\text { em meio aos eventos realizados nos locais de } \\
\text { competições olímpicas no Rio. Entre os principais } \\
\text { conteúdos utilizados, aparecem o sítio do Comitê } \\
\text { Olímpico do Brasil e a página oficial dos Jogos de } \\
\text { 2016, do Comitê Olímpico Internacional. }\end{array}$ \\
\hline $\begin{array}{l}\text { Me lembro de uma entrevista com um padre, } \\
\text { que foi uma ideia que eu retirei precisamente do } \\
\text { site do COB. Depois aprofundei e consegui }\end{array}$ & $\begin{array}{l}\text { O jornalista recorda de um caso peculiar em que leu } \\
\text { uma notícia a partir do site do COB e se inspirou }\end{array}$ \\
\hline
\end{tabular}


estar com ele pessoalmente, mas foi uma dica importante para fazer um trabalho interessante e diferente.

para produzir um trabalho diferenciado para o Maisfutebol.

Cunha (2017) menciona a utilização do site do COB diariamente como forma de se manter informado sobre os eventos realizados nos locais de competição olímpica no Rio de Janeiro. Para o jornalista e editor, a recorrência a essa fonte se deu mesmo antes das Olimpíadas.

Duas fontes provenientes da web tiveram importância: tanto a página do Comitê como o sítio oficial dos Jogos de 2016 (a partir do IOC). Como exemplo, o jornalista menciona a inspiração de pauta, a partir de uma notícia publicada pela página do $\mathrm{COB}$, para a produção de "um trabalho interessante e diferenciado" para o Maisfutebol.

\subsubsection{Análise crítica dos resultados}

Uma fala sobre o trabalho credenciado com os direitos de transmissão merece especial destaque no que tange às limitações da cobertura sem acreditações. Recapitulando um trecho da entrevista com Eurico (2017), torna-se claro que:

[...] não poder ver os acontecimentos de um atleta que acaba de ganhar uma medalha... Isso, na pele de um jornalista, é super frustrante. Portanto, ter a possibilidade de ter direitos de transmissão, como nós tivemos, é excelente. [...] basicamente, tendo os direitos, o trabalho tem mais brilho.

O pensamento do jornalista português articula exatamente a qualidade da informação jornalística quando se executa a apuração no próprio local do acontecimento. Ademais, algumas características da premissa desta tese ficaram mais evidenciadas: seja no Brasil ou em Portugal, os jornalistas e as equipes de mídia trabalham sem depender exclusivamente de fontes institucionais. As redes sociais dos atletas e o contato com federações parecem servir, muitas vezes, de fonte de informação para pautas e matérias. Isso aparenta ocorrer com mais frequência em veículos pequenos e independentes.

A principal comparação entre os credenciados e que ilustra também essa forma de trabalho envolve, no Brasil, os casos da EPTV (afiliada da Rede Globo, emissora oficial dos Jogos Olímpicos de 2016) e SporTV; e em Portugal, o jornal O Jogo e as emissoras de rádio Antena 1 e o canal RTP. Essas organizações optaram por produzir as notícias de maneira autônoma, a partir de pautas desenvolvidas pelos próprios profissionais da imprensa. 
No caso de referências da $w e b$, os canais brasileiros tiveram tanto o IOC (a intranet para jornalistas acreditados e a página oficial) como do site do COB como fontes jornalísticas. Referente às fontes utilizadas na cobertura de Portugal, a página do COB possuiu uma importância reduzida devido ao foco serem os atletas da delegação brasileira, embora a usabilidade da página apresente indícios de reconhecimento como ferramenta útil para os profissionais estrangeiros. 


\section{CONSIDERAÇÕES FINAIS}

Esta tese teve início com uma pesquisa referente à ontologia e deontologia do jornalismo esportivo no Brasil a partir da realização dos Jogos Olímpicos do Rio de Janeiro, em 2016. Com isso também foi possível compreender o desenvolvimento da pauta olímpica no Brasil em momentos anteriores ao início dos Jogos. Posteriormente, o acompanhamento do site do COB serviu de base para entender o material produzido pelo Comitê.

O foco no material noticioso disponibilizado pelo Comitê em sua página eletrônica evidenciou a necessidade de uma visita técnica às dependências do $\mathrm{COB}$ em um momento posterior à realização das Olimpíadas, uma vez que, até o evento, os jornalistas estavam envolvidos na cobertura dos Jogos. Tratou-se de uma importante oportunidade para dialogar com esses jornalistas sobre o trabalho realizado do site do COB.

A discussão sobre o desenvolvimento da pauta olímpica no jornalismo esportivo do Brasil resvalou quase que diretamente na questão do prestígio do futebol diante de outras modalidades, algumas delas com pouca familiaridade ou desconhecidas dos brasileiros. Exatamente por isso, em algumas das 27 entrevistas com pesquisadores e/ou jornalistas houve considerações em relação à necessidade de se desenvolver estratégias que contribuam para a formação de atletas em meio aos valores da cultura olímpica.

A realização dos Jogos Olímpicos no Rio de Janeiro tornou próximos alguns assuntos distanciados do cotidiano do jornalista brasileiro, como a pauta olímpica e como ela tangencia as expectativas - comentários, previsões e análises - do trabalho jornalístico. Ademais, verificar o espaço desigual das modalidades olímpicas diante do privilégio de uma única delas - o futebol - permitiu refletir porque esta categoria dispõe de inúmeros anunciantes, bem mais que o conjunto das outras. Esse ponto aparece inserido no dilema da monocultura esportiva brasileira.

No quesito da mídia convencional (ou canais de mais prestígio de audiência), evidenciam-se vários aspectos favoráveis para se contar com outros esportes ou tornar alguma modalidade Prime. Entretanto, muita dificuldade ainda reside na questão do patrocínio, suscitada pelos jornalistas do $\mathrm{COB}$ e pelos pesquisadores de jornalismo esportivo, referente à questão de se formar uma cultura com os esportes olímpicos e atrair mais interesse para os atletas das categorias de base.

Para os canais alternativos, muitos deles fundados a partir das redes e ferramentas da internet, um dos entraves apontados durante a consulta aos jornalistas foi a dificuldade de credenciamento e do trabalho in loco. Entretanto, um elemento merece ressalva nesse 
aspecto e diz respeito tanto à cobertura realizada por brasileiros como por portugueses, principalmente àqueles que integravam a imprensa regional: a utilização de redes sociais como forma de contatar os protagonistas dos Jogos, os atletas olímpicos ou suas federações, na hora de construir a pauta e realizar o trabalho de cobertura.

A fim de se vislumbrar como se distribuem os resultados obtidos nesta tese, apresenta-se a articulação da premissa e da hipótese diante da utilização do site do COB como fonte para a cobertura realizada por jornalistas esportivos do evento do Rio de Janeiro em 2016:

\section{Quadro 7 - Mídia convencional x mídia alternativa e especializada: síntese}

\begin{tabular}{|c|c|c|}
\hline & $\begin{array}{c}\text { Mídia convencional } \\
\text { (jornais, rádio e televisão) }\end{array}$ & $\begin{array}{l}\text { Mídias alternativas e especializadas } \\
(\text { blogs e sites })\end{array}$ \\
\hline Tipo de cobertura & $\begin{array}{l}\text { In loco, com equipes na redação } \\
\text { responsável pela consulta às fontes e } \\
\text { atuando de forma sincronizada com os } \\
\text { repórteres em campo a fim de } \\
\text { respaldar seus repertórios. }\end{array}$ & $\begin{array}{l}\text { In loco, com equipe dividida entre o } \\
\text { evento em si e outra para a produção de } \\
\text { análises. Consulta a fontes de internet } \\
\text { voltada às estatísticas e dos atletas } \\
\text { envolvidos. }\end{array}$ \\
\hline Tipo de cobertura & $\begin{array}{l}\text { A distância: repórteres e editores } \\
\text { recorrem a fontes da web como meio } \\
\text { de aproximação aos locais das } \\
\text { partidas, além das informações sobre } \\
\text { resultados, estatísticas e dados sobre os } \\
\text { atletas. }\end{array}$ & $\begin{array}{l}\text { À distância: recorrência a websites que } \\
\text { publicaram material jornalístico de } \\
\text { forma acessível, além das redes sociais } \\
\text { dos atletas. }\end{array}$ \\
\hline
\end{tabular}

Fonte: elaboração própria

Desta maneira, retoma-se a premissa sobre o envolvimento dos jornalistas que fazem a cobertura com a consulta de fontes da web: quanto menos credenciado for o jornalista, mais probabilidade de recorrer ao site do COB como fonte para a busca de informação e produção de notícias. Ainda assim, consolida-se também a hipótese de que o site do Comitê serviu como fonte de caráter primário nas pesquisas realizadas pelas equipes de redação, ajudando nas pautas e no repertório dos repórteres in loco.

Para os jornalistas que não estiveram presentes ao evento, a página online tornou-se uma fonte prioritária de consulta e referência na produção do webjornalismo ou outro tipo de informação (artigos, comentários etc.) devido aos recursos que ofereceu, como placar, fichas de atletas e informações de partidas, disponibilizando textos e fotografias de maneira acessível e gratuita.

Embora a usabilidade do site tenha merecido diferentes avaliações por parte dos entrevistados, ressalte-se que o espaço foi constantemente e por todos eles apontado como 
uma fonte confiável de dados que pudessem subsidiar os trabalhos de pauta e de produção de reportagens.

A configuração do site do COB como fonte oficial tem, no entanto, uma percepção ambígua. Isso se explica na opção de alguns jornalistas por não usar o site, por exemplo, na composição de material sobre a qualidade da infraestrutura da cidade do Rio de Janeiro para os Jogos. Alguns profissionais preferiram recorrer ao espaço apenas para buscar informações técnicas, como o calendário das competições.

Parte dos dados que subsidia este estudo foi colhida por meio de levantamento bibliográfico. Entretanto, merece atenção o caráter decisivo do conteúdo das entrevistas realizadas por este autor com pesquisadores e jornalistas no Brasil, em Portugal e até mesmo na Espanha. Neste sentido, destaca-se a importância das etapas dos estágios doutorais em Campo Grande - entre agosto a dezembro de 2015, por meio do Programa Nacional de Cooperação Acadêmica (PROCAD) entre os Programas de Pós-Graduação da Universidade de São Paulo, Universidade Federal do Rio Grande do Norte e da Universidade Federal de Mato Grosso do Sul - e na Universidade do Minho, em Portugal, de outubro a dezembro de 2017. Além disso, enfatiza-se o importante espaço aberto pelos profissionais que integram o Comitê Olímpico do Brasil para as conversas sobre o site do COB, seus objetivos e sua atuação.

Espera-se que eventuais caminhos e questionamentos suscitados por este trabalho venham a contribuir ou inspirar uma demanda que aponte para a continuidade dos estudos relacionados ao jornalismo esportivo e olímpico no Brasil. 


\section{REFERÊNCIAS}

AMARAL, Luiz. Jornalismo: matéria de primeira página. $3^{\text {a }}$. ed. Rio de Janeiro: Tempo Brasileiro/UFC, 1982.

BALSEBRE, Armand. A linguagem radiofônica. In: MEDITSCH, Eduardo (Org.). Teorias do rádio: textos e contextos. Florianópolis: Insular, 2005. p. 327-336.

BARDIN, Laurence. Análise de conteúdo. Tradução: Luís Antero Reto e Augusto Pinheiro. Extra Colecção. Lisboa: Edições 70, 2008.

BAUDRILLARD, Jean. Simulacros e simulação. Tradução: Maria João da Costa Pereira. Lisboa: Relógio d'água, 1981.

BERNAL TORRES, Cesar Augusto. Metodología de la investigación. $3^{\mathrm{a}}$. ed. Bogotá: Prentice Hall, 2010.

BIAGI, Shirley. Media impact: an introduction to mass media (Wadsworth Series in Mass Communication and Journalism: General Mass Communication). Stamford: Cemgage Learning, 2001.

BOHM, David. Diálogo: comunicação e redes de convivência. Tradução: Humberto Mariotti. São Paulo: Palas Athena, 2005.

BOLTER, Jay David; GRUSIN, Richard. Remediation: understanding new media. Masachusets: MIT Press, 2000.

BUENO, Wilson da Costa. Chutando prá fora: os equívocos do jornalismo esportivo brasileiro. In: MARQUES, José Carlos; CARVALHO, Sérgio; CAMARGO, Vera Regina (Orgs.). Comunicação e esporte: tendências. Santa Maria: Pallotti/Intercom, 2005.

CAMPBELL, Joseph. Yellow journalism: puncturing the myths, defining the legacies. Westport: Praeger Publishers, 2001.

CANAVILHAS, João. Webjornalismo: Da Pirâmide invertida à pirâmide deitada. Covilhã: Universidade da Beira Interior. 2006. Disponível em: $<$ http://www.bocc.ubi.pt/pag/canavilhas-joao-webjornalismo-piramide-invertida.pdf $>$. Acesso em: 12 dez. 2017.

CARVALHO, Sérgio. Hora da ginástica: resgate da obra do Professor Oswaldo Diniz Magalhães. Santa Maria: UFMS, 1994.

CASTELLS, Manuel. A sociedade em rede. Tradução: Roneide V. Majer. $6^{\text {a }}$. ed. São Paulo: Paz e Terra, 2011.

A galáxia internet: reflexões sobre internet, negócios e sociedade. Tradução: Rita Espanha, Gustavo Cardoso e José Manuel Paquete de Oliveira. Lisboa: Fundação Calouste Gulbenkian, 2004.

CHAPARRO, Manuel Carlos. Jornalismo: a linguagem dos conflitos. São Paulo: Edição do Autor, 2014.

CIMADEVILLA, Gustavo. Siempre a la vanguardia de su tiempo: Entrevista a Miquel de Moragas Spà. Revista Latino-Americana de Ciencias de la Comunicación. Ano 3, nº 4. São Paulo: ALAIC, 2006, p. 90-96.

DAMATTA, Roberto. O que faz do Brasil, Brasil? Rio de Janeiro: Rocco, 1986. Antropologia do óbvio: notas em torno do significado social do futebol brasileiro. 
In: Revista USP. Dossiê futebol, $n^{\circ}$. 22. São Paulo: Universidade de São Paulo, junhoagosto de 1994, p. 10-17.

DAMATTA, Roberto et al. Universo do futebol: esporte e sociedade brasileira. Rio de Janeiro: Pinakotheke, 1982.

DEBORD, Guy. A sociedade do espetáculo. Rio de Janeiro: Contraponto, 1997.

ECO, Umberto. Viagem na irrealidade cotidiana. Rio de Janeiro: Nova Fronteira: 1984.

EHRENBERG, Karla Caldas. Bola na rede: uma análise das estratégias comunicacionais de empresas esportivas no ambiente digital e conectado. Tese (Doutorado). Orientador: Prof. Dr. Wilson da Costa Bueno. São Bernardo do Campo: Universidade Metodista de São Paulo, 2016.

ERBOLATO, Mário. Jornalismo especializado: emissão de textos no jornalismo impresso. São Paulo: Atlas, 1981.

Técnicas de codificação em jornalismo. Petrópolis: Vozes, 1978.

FERRARI, Pollyana. A força da mídia social. São Paulo: Editora Estação das Letras e Cores, 2010a.

Comunicação digital na era da participação. Porto Alegre: Editora Fi: 2016.

Jornalismo digital. 4a . ed. Coleção Comunicação. São Paulo: Contexto, 2010b.

FONSECA, Ouhydes João Augusto da. O cartola e o jornalista: influência da política clubística no jornalismo esportivo. Tese (Doutorado). Orientador: Prof. Dr. Francisco Gaudêncio Torquato do Rego. São Paulo: Universidade de São Paulo, 1981.

GARCIA, Wilton. O metrossexual no Brasil. São Paulo: Factash, 2011.

GARCÍA, Xosé López. Ciberperiodismo en la proximidad. Coleción Periodística, n. 25. Sevilla: CS Comunicación Social, 2008.

GARCÍA, Xosé López; TOURAL BRAN, Carlos; FERNÁNDEZ, Moisés Limia. Los medios digitales en Galicia y las nuevas herramientas de la web 2.0/3.0. In: Nuevos Medios, Nueva Comunicación (II Congreso Internacional Comunicación 3.0). Salamanca: Universidade de Salamanca, 2010. Disponível em: <http://campus.usal.es/ comunicacion3punto0/comunicaciones/068.pdf >. Acesso em: 13 dez. 2017.

GUERRA, Márcio de Oliveira. Você, ouvinte, é a nossa meta: a importância do rádio no imaginário do torcedor de futebol. Juiz de Fora: Editora Etc, 2000.

GUMBRECHT, Hans Ulrich. Nosso amplo presente: o tempo e a cultura contemporânea. Tradução: Ana Isabel Soares. São Paulo: Unesp editora, 2015.

GURGEL, Anderson et al. Comunicação e esporte: reflexões. Coleção GP'S, volume 1. São Paulo: Intercom: 2012.

GURGEL, Anderson. Desafios do jornalismo na era dos megaeventos esportivos. Revista Motrivivência, ano XXI, nº 32/33, p. 193-210, jun-dez, 2009.

HAGEN, John B. Radio-Frequency Electronics: circuits and applications. 2a . ed. New York: Cambridge University Press, 2009.

HALL, Stuart. Da diáspora: identidades e mediações culturais. In: SOVIK, Liv (Org.). Coleção Humanitas. Belo Horizonte: Ed. UFMG, 2003.

HOEVEN, Jeffrey van der; LOHMAN, Bram; VERDEGEM, Remco. Emulation for Digital 
Preservation in Practice: the results. In: The International Journal of Digital Curation 2.2. London, 2007.

HOHENBERG, John. O jornalista profissional: guia às práticas e aos princípios dos meios de comunicação de massa. Rio de Janeiro: Interamericana, 1981.

HOWE, Jeff. O poder das multidões: por que a força da coletividade está remodelando o futuro dos negócios. Rio de Janeiro: Elsevier, 2009.

HUIZINGA, Johan. Homo ludens. 7ª ed. São Paulo: Perspectiva, 2012.

JENKINS, Henry. Cultura da convergência. 2a . ed. São Paulo: Aleph, 2009.

Fans, bloggers and gamers: exploring participatory culture. New York: NY University Press, 2006.

JOHNSON, Steven. Cultura da interface: como o computador transforma nossa maneira de criar e comunicar. Tradução: Maria Luiza Borges. Rio de Janeiro: Zahar, 2001.

KEEN, Andrew. Vertigem digital: por que as redes sociais estão nos dividindo, diminuindo e desorientando. Tradução: Alexandre Martins. Rio de Janeiro: Zahar, 2012.

LAGE, Nilson. A reportagem: teoria e técnica de entrevista e pesquisa jornalística. $11^{\mathrm{a}}$ ed. Rio de Janeiro, Record: 2014.

LEMKE, Jay. Cultural analysis across media: games, franchises, and the new cultural order. First International Conference on Critical Discourse Analysis. Valencia: Universitat de València, 2004. Disponível em: <http://jaylemke.squarespace.com/storage/GamesFranchises-CulturalOrder-2005.pdf>. Acesso em: 23 jul. 2014.

LEONHARD, Gerd. Friction is fiction: essays, writings and blog posts. Black and White 3.0 edition. Basel: Mediafuturist, $2010 . \quad$ Disponível em:<http://www.futuristgerd.com/2010/05/12/friction-is-fiction-the-future-of-mediabusiness-my-presentation-at-next10-berlin>. Acesso em: 02 fev. 2014.

LEVER, Janet. A loucura do futebol. Rio de Janeiro: Record, 1983.

LÉVY, Pierre. O que é o virtual? Tradução: Paulo Neves. São Paulo: Editora 34, 1997.

Cibercultura. Tradução: Carlos Irineu da Costa. $2^{a}$. ed. Coleção Trans. São Paulo: Editora 34, 1999.

MACHADO, Elias. O ciberespaço como fonte para os jornalistas. Salvador: Calandra, 2003.

MACIEL, Suely et al. Acessibilidade e inclusão: projeto biblioteca falada e a audiodescrição de produtos audiovisuais. Revista Panorama: Revista de Comunicação Social, Goiânia, v. 6, n. 1, p. 24-30, jun. 2016. ISSN 2237-1087. Disponível em: <http://seer.pucgoias.edu.br/index.php/panorama/article/view/4859>. Acesso em: 28 ago. 2018.

MALULY, Luciano Victor Barros. Jornalismo esportivo: princípios e técnicas. São Paulo: Edição do Autor, 2017.

.; TAVARES Jr, Carlos A. Entrevista com Manuel Joaquim Silva Pinto Abordagens em torno da pesquisa em e sobre jornalismo. Comunicação \& Sociedade (Online), v. 40, 2018. 
MARQUES, José Carlos (Org.). Comunicação e esporte: diálogos possíveis. Coleção NPs 7. São Paulo: Artcolor/Intercom, 2007.

Tá tranquilo, tá favorável: a cobertura brasileira dos Jogos Olímpicos do Rio de Janeiro 2016. Revista USP, v. 1, n. 108. São Paulo: USP, 2016.

MARTÍN-BARBERO, Jesús. De los medios a las mediaciones: comunicación, cultura y hegemonía. Barcelona: Anthropos Editorial, 2010.

MASI, Domenico De. 2025: caminhos da cultura no Brasil. Rio de Janeiro: Sextante, 2015.

MEDINA, Cremilda. Atravessagem: reflexos e reflexões na memória de repórter. São Paulo: Summus, 2014.

Entrevista: o diálogo possível. São Paulo: Ática, 1986.

Notícia: um produto à venda. $2^{\mathrm{a}}$. ed. São Paulo: Summus, 1988.

MILAN, Betty. O País do Futebol. Rio de Janeiro: Record, 1998.

MINAYO, Maria Cecília de Souza (Org.). Pesquisa social: teoria, método e criatividade. Petrópolis: Vozes, 1994.

MONTERO, Tamara. Ramón Salaverría: O xornalismo debe ser flexible na tecnoloxía e inflexible nos seus valores. A voz de Galiza. Caderno Televisión. Santiago de Compostela, 08/06/2017. Disponível em: $<$ https://galego.lavozdegalicia.es/noticia/television/2017/06/08/periodismo-debe-flexibletecnologia-inflexible-valores/0003_201706G8P60993.htm>. Acesso em: 15 mar. 2018.

MORAES JÚNIOR, Enio. O ensino do interesse público na formação de jornalistas: elementos para a construção de uma pedagogia. Tese (Doutorado). Orientador: Prof. Dr. José Coelho Sobrinho. São Paulo: Universidade de São Paulo, 2011.

MORAES JÚNIOR, Enio; MALULY, Luciano Victor Barros; OLIVEIRA, Dennis de (Orgs). Antes da pauta: linhas para pensar o ensino de jornalismo no século XXI. São Paulo: ECA/USP, 2013. Disponível em: <http://www.usp.br/cje/wpcontent/uploads/2017/06/antesdapauta.pdf >. Acesso em: 15 abr. 2015.

MORAGAS SPÀ, Miquel de. Comunicación y deporte en la era digital. Barcelona: Centre d'Estudis Olímpics. Barcelona: Universitat Autonòma de Barcelona, 2007. Disponível em: <http://olympicstudies.uab.es/pdf/wp107_spa.pdf>. Acesso em: 15 abr. 2016.

OCTÁVIO, Chico; MELLO, Bernardo. MP denuncia Cabral, Nuzman e mais quatro após Operação Unfair Play. Jornal O Globo. Rio de Janeiro, 08 de outubro de 2017. Disponível em: <https://oglobo.globo.com/esportes/mp-denuncia-cabral-nuzman-mais-quatro-aposoperacao-unfair-play-21960489>. Acesso em: 29 nov. 2018.

OLIVEIRA, Nelma Gusmão de. O poder dos Jogos e os Jogos de poder: os interesses em campo na produção de uma cidade para o espetáculo esportivo. Tese (Doutorado). Orientador: Prof. Dr. Carlos Bernardo Vainer. Rio de Janeiro: Universidade Federal do Rio de Janeiro, 2012.

PAULA, Daniela Ferreira Lima de. Fotografias instantâneas: o Instagram como possibilidade tecnológica. Dissertação (Mestrado). Orientador: Prof. Dr. Wilton Garcia. Sorocaba: Universidade de Sorocaba, 2015.

PINOTTI, José Luiz. Comunicação e audiodescrição: estudos contemporâneos. Dissertação (Mestrado). Orientador: Prof. Dr. Wilton Garcia. Sorocaba: Universidade de Sorocaba, 2014. 
PINTO, Manuel. Fontes jornalísticas: contributos para o mapeamento do campo. Comunicação e Sociedade 2. São Bernardo do Campo, 2000, p. 277-294.

REPPOLD FILHO, A. et al. Olimpismo e educação olímpica no Brasil. Porto Alegre: Editora da UFRS, 2009.

ROCCO JÚNIOR. Ary. Marketing e gestão do esporte. São Paulo: Atlas, 2015.

ROCHA, Liana Vidigal; MALULY, Luciano Victor Barros. Webjornalismo esportivo: entre os espaços alternativos e os tradicionais. In:XXXIX Congresso Brasileiro de Ciências da Comunicação. Anais Intercom. São Paulo: USP, 2016. Disponível em: <http://portalintercom.org.br/anais/nacional2016/resumos/R11-0768-1.pdf>. Acesso em: 22 out. 2017.

ROCHA, Vera Lúcia. Cronologia do rádio paulistano. São Paulo: Centro Cultural de São Paulo, 1993.

ROGERS, Everett. Diffusion of innovations. 5a . ed. New York: Free Press, 2003.

ROSA, Maria Virgínia F. P. de.; ARNOLDI, Marlene Aparecida G. C. A entrevista na pesquisa qualitativa: mecanismos para validação dos resultados. Belo Horizonte: Autêntica, 2006.

RUBIO, Kátia. Biographical narratives of olympic athletes: an access road to identity and Brazilian sports imagery. In: American International Journal of Social Science, New York, v. 4, n. 1, p. 85-90, fev. 2015.

RÜDIGER, Francisco Ricardo. Introdução às teorias da cibercultura: perspectiva do pensamento tecnológico contemporâneo. Porto Alegre: Sulina, 2007.

SALAVERRÍA, Ramón. Tipología de los cibermedios periodísticos: bases teóricas para su clasificación. Revista Mediterránea de Comunicación / Mediterranean Journal of Communication, [S.1.], v. 8, n. 1, p. 19-32, ene. 2017. ISSN 1989-872X. Disponível em: $<$ https://www.mediterranea-comunicacion.org/article/view/2017-v8-n1-tipologia-de-loscibermedios-periodisticos-bases-teoricas-para-su-clasificacion>. Acesso em: 25 mar. 2018.

SALAVERRÍA, Ramón; NEGREDO, Samuel. Periodismo integrado: convergencia de medios y reorganización de redacciones. Barcelona: Editorial Sol 90, 2008.

SALAVERRÍA, Ramón; SANCHO, Francisco. Del papel a la Web. Evolución y claves del diseño periodístico en internet. In: LARRONDO, A.; SERRANO, A. (eds.). Diseño periodístico en internet. Leioa: Servicio Editorial de la Universidad del País Vasco, 2007, p. 207-239. Disponível em: <http://hdl.handle.net/10171/5074〉. Acesso em: 28 nov. 2018.

SCHMITZ, Aldo Antônio. Fontes jornalísticas: ações e estratégias das fontes no jornalismo. Florianópolis: Combook, 2011. Disponível em: $<$ https://www.cairu.br/biblioteca/arquivos/Comunicacao/Fontes_noticias.pdf $>$. Acesso em: 12 dez. 2018.

SHIRKY, Clay. A cultura da participação: criatividade e generosidade no mundo conectado. Rio de Janeiro: Jorge Zahar, 2011.

SLATER, John. Changing partners: the relationship between the mass media and the olympic games. In: Fourth International Symposium For Olympic Research. London: University of Western Ontario, 1998, p. 49-69.

SOARES, Edileuza. A bola no ar: o rádio esportivo em São Paulo. São Paulo: Summus, 1999. 
STRAUBHAAR, Joseph. Sedimentada, híbrida e múltipla? A nova geografia cultural das identidades. Revista Matrizes, Ano 7 - nº 1. São Paulo: ECA/USP, jan./jun. 2013.

TAMBUCCI, Pascoal et al. (Orgs.). Esporte e jornalismo. São Paulo: CEPEUSP, 1997.

TAVARES JUNIOR, Carlos A. Jornalismo esportivo: o que é. Pauta Geral - Estudos em jornalismo, v. 4, 2017, p. 38-59.

p. $189-203$.

Jornalismo esportivo: da cobertura olímpica ao projeto Rio 2016. Tríade, v. 3, 2015,

A pauta do jornalismo esportivo: interfaces olímpicas. In: IX Encontro de Pesquisadores de Comunicação e Cultura (Anais). Sorocaba: Universidade de Sorocaba; ECA-USP; Fapesp, 2015.

A pauta esportiva do jornalismo: interfaces nos jogos do Rio 2016. In: XXXVIII Congresso Brasileiro de Ciências da Comunicação (Anais) - Rio de Janeiro: UFRJ/INTERCOM, 2015.

Rio 2016: jornalismo além do futebol. In: X Encontro de Pesquisadores de Comunicação e Cultura (Anais). Sorocaba - SP: Universidade de Sorocaba, 2016.

Jornalismo esportivo: a pauta olímpica no Brasil. In: XXXIX Congresso Intercom (Anais). São Paulo: INTERCOM; ECA/USP, 2016.

Jornalismo esportivo: influências da prática na profissão. In: XXI Congresso de Ciências da Comunicação da Região Sudeste - Anais. Salto - SP: Intercom/Ceunsp, 2016.

Rio de Janeiro 2016: olimpíadas, legados e aprendizados. In: XXII Congresso de Ciências da Comunicação (Região Sudeste) - Anais. Volta Redonda: Sociedade Brasileira de Estudos Interdisciplinares da Comunicação, 2017.

O jornalismo do Comitê Olímpico do Brasil: da pauta aos meios. In: Conexão Pós: diálogos e intersecções na pesquisa discente - ANAIS. São Paulo - SP: Escola de Comunicações e Artes da Universidade de São Paulo, 2017.

Rio 2016: uma cobertura via web. In: Seminário de Tecnologia, Educação e Sociedade: conhecer e inovar com criatividade (ANAIS). Itaquaquecetuba: Fatec Itaquaquecetuba, 2017.

Jornalismo esportivo: o esvaziamento dos projetos Rio 2016 e legados olímpicos. In: XX Congresso de Ciências da Comunicação da Região Centro-Oeste (Anais). Campo Grande: Intercom; Universidade Federal do Mato Grosso do Sul, 2018.

TÁVOLA. Artur da. Comunicação é mito. Rio de Janeiro: Nova Fronteira, 1985.

TRIVIÑOS. Augusto Nibaldo Silva. Introdução à pesquisa em Ciências Sociais: a pesquisa qualitativa em educação. São Paulo: Atlas, 1987.

TOFFLER, Alvin. A terceira onda. Tradução: João Távora. $8^{\mathrm{a}}$. ed. Rio de Janeiro: Record, 1980.

TOURAL BRAN, Carlos. A información deportiva sobre baloncesto nos medios de comunicación españóis. Tese (Doutorado). Orientadores: Prof. Dr. Xosé López García e Prof. Dr. Xosé Pereira-Fariña. Santiago de Compostela: Universidade Santiago de Compostela, 2013.

TUBINO, Manoel José Gomes. O que é olimpismo? Coleção Primeiros Passos, nº 320. São Paulo: Brasiliense, 2007. 
WOLTON, Dominique. Informar não é comunicar. Porto Alegre: Sulina, 2011.

\section{Referências eletrônicas (webgrafia)}

COMITÊ Olímpico do Brasil. Site. Disponível em: <http://www.cob.org.br>. Acesso em: 06 jul. 2014.

Diretrizes do COI para a Mídia Social e Digital para pessoas credenciadas para os XXXI Jogos Olímpicos Rio $2016 . \quad$ Disponível em: $<$ http://cob.org.br/Handlers/RecuperaDocumento.ashx?codigo=4539>. Acesso em: 26 jul. 2016.

. Olimpismo: sua origem e ideais. Rio de Janeiro: COB, 2012. Disponível em: $\langle$ https://www.cob.org.br/Handlers/RecuperaDocumento.ashx?codigo=1170>. Acesso em: 25 mai. 2015.

G1. Site. Disponível em: <http://g1.globo.com>. Acesso em: 22 jul. 2017.

JORNAL O Globo. Disponível em: <https://oglobo.globo.com>. Acesso em: 29 nov. 2018.

INTERCOM. Congresso Brasileiro de Ciências da Comunicação. Anais 2016. Disponível em: 〈http://portalintercom.org.br/anais/nacional2016>. Acesso em: 29 nov. 2018.

PLATAFORMA Sucupirar Site. Disponível em: <https://sucupira.capes.gov.br/sucupira/public/consultas/coleta/veiculoPublicacaoQualis/li staConsultaGeralPeriodicos.jsf >. Acesso em: 18 nov. 2018.

REPOSITÓRIO da Universidade do Minho. Disponível em: <http://repositorium.sdum.uminho.pt>. Acesso em: 29 mai. 2017.

REPOSITÓRIO da Universidade Santiago de Compostela. Disponível em: <https://minerva.usc.es/xmlui/?locale-attribute=gl>. Acesso em: 30 nov. 2018.

REDE Nacional do Esporte. Site. Disponível em: <http://www.brasil2016.gov.br/ptbr/incentivo-ao-esporte/lei-agnelo-piva)>. Acesso em: 20 mai. 2017.

RIO Cidade Olímpica. Canal de vídeos no YouTube. Disponível em: <https://www.youtube.com/channel/UCaHqCxzD3qiU-WRZwpwm7hw>. Acesso em: 29 mai. 2016.

SPORTV. Site. Disponível em: 〈https://sportv.globo.com/site〉. Acesso em: 28 mai. 2016.

\section{Documentos sonoros (entrevistas)}

ANTONIO, Victor Sá Ramalho. Entrevista: Victor Sá Ramalho Antonio [abr. 2018]. Entrevistador: Carlos Augusto Tavares Junior. São Paulo: FFLCH-USP, 2018. 1 arquivo. WAV (25,2 min.).

BULLARA, Rafael. Entrevista: Rafael Bullara [ago. 2018]. Entrevistador: Carlos Augusto Tavares Junior. São Paulo: Shopping JK Vila Olímpia, 2018. 1 arquivo. WAV (2,5 min.).

CARDOSO NETO, Geraldo Armando. Entrevista: Geraldo Armando Cardoso Neto [ago. 2018]. Entrevistador: Carlos Augusto Tavares Junior. Ribeirão Preto: EPTV, 2018. 1 arquivo. WAV (2,5 min.). 
CHAPARRO, Manuel Carlos. Entrevista: Prof. Dr. Manuel Carlos Chaparro [set. 2015]. Entrevistador: Carlos Augusto Tavares Junior. Rio de Janeiro: ECO/UFRJ, 2015. 1 arquivo. WAV (5,4 min).

CUNHA, Pedro Jorge da. Entrevista: Pedro Jorge da Cunha [dez. 2017]. Entrevistador: Carlos Augusto Tavares Junior. Porto: Grupo Media Capital, 2017. 1 arquivo. WAV (5,4 min.).

EURICO, Fernando. Entrevista: Fernando Eurico [nov. 2017]. Entrevistador: Carlos Augusto Tavares Junior. Porto: Rádio e Televisão de Portugal - RTP, 2017. 1 arquivo. WAV (23,1 min.).

FLÓRIDO, Carlos. Entrevista: Carlos Flórido [nov. 2017]. Entrevistador: Carlos Augusto Tavares Junior. Porto: Global Media Group, 2017. 1 arquivo. WAV (33,4 min.).

FRANÇA, Fábio. Entrevista: Fábio França [mai. 2018]. Entrevistador: Carlos Augusto Tavares Junior. São Paulo: Grupo Bandeirantes de Comunicação, 2018. 1 arquivo. WAV (10,1 min.).

FREITAS, Eva Regina. Entrevista: Eva Regina Freitas [nov. 2015]. Entrevistador: Carlos Augusto Tavares Junior. Campo Grande: Palácio das Comunicações, 2015. 1 arquivo. WAV (10 min.).

GIGLIO, Sérgio Settani. Entrevista: Prof. Dr. Sérgio Settani Giglio [set. 2018]. Entrevistador: Carlos Augusto Tavares Junior. São Paulo: USP, 2015. 1 arquivo. WAV (6,4 min.).

GROLL, Marcus Von. Entrevista: Marcus Von Groll [set. 2018]. Entrevistador: Carlos Augusto Tavares Junior. Porto Alegre: Charrua Clube, 2018. 1 arquivo. WAV (10,3 min.).

GUERRA, Márcio de Oliveira. Entrevista: Prof. Dr. Márcio de Oliveira Guerra [set. 2015]. Entrevistador: Carlos Augusto Tavares Junior. Rio de Janeiro: ECO/UFRJ, 2015.

GURGEL, Anderson. Entrevista: Prof. Dr. Anderson Gurgel [set. 2015]. Entrevistador: Carlos Augusto Tavares Junior. Rio de Janeiro: ECO/UFRJ, 2015. 1 arquivo. WAV (4,5 $\min )$.

HELAL, Ronaldo George. Entrevista: Prof. Dr. Ronaldo George Helal [set. 2015]. Entrevistador: Carlos Augusto Tavares Junior. Rio de Janeiro: ECO/UFRJ, 2015. 1 arquivo. WAV (2 min.).

LEITE, José Ricardo Campos. Entrevista: José Ricardo Campos Leite [abr. 2018]. Entrevistador: Carlos Augusto Tavares Junior. Rio de Janeiro: FOX Entertainment Group, 2018. 1 arquivo. WAV (11,2 min.).

MACHADO, Carlos Miguel. Entrevista: Carlos Miguel Machado [out. 2017]. Entrevistador: Carlos Augusto Tavares Junior. Braga: Universidade do Minho, 2017. 1 arquivo. WAV (21,1 min.).

MARQUES. José Carlos. Entrevista: Prof. Dr. José Carlos Marques [set. 2015]. Entrevistador: Carlos Augusto Tavares Junior. Rio de Janeiro: ECO/UFRJ, 2015. 1 arquivo. WAV (1,5 min.).

MOTTA, Cláudio; DAWES, Christian; WINCKLER, Adriano. Entrevista: Visita técnica ao Comitê Olímpico do Brasil [mai. 2017]. Entrevistador: Carlos Augusto Tavares Junior. Rio de Janeiro: COB, 2017. 1 arquivo. WAV (73,1 min.). 
PINTO, Manuel. Entrevista: Prof. Dr. Manuel Joaquim Silva Pinto [dez. 2017]. Entrevistador: Carlos Augusto Tavares Junior. Braga: Café Vianna, 2017. 1 arquivo. WAV (19,5 min.).

PRATES, Vitor. Entrevista: Vitor Prates [set. 2018]. Entrevistador: Carlos Augusto Tavares Junior. Piracicaba: Rádio Educativa FM, 2018. 1 arquivo. WAV (3,2 min.).

RAMALHO, Arthur Mário Medeiros. Entrevista: Arthur Mário Medeiros Ramalho [nov. 2015]. Entrevistador: Carlos Augusto Tavares Junior. Campo Grande: Rádio Cultura AM 680, 2015. 1 arquivo. WAV (17,2 min.).

ROCCO JÚNIOR, Ary. Entrevista: Prof. Dr. Ary Rocco Junior [set. 2015]. Entrevistador: Carlos Augusto Tavares Junior. Rio de Janeiro: ECO/UFRJ, 2015. 1 arquivo. WAV (2,5 $\min$. .).

SARAIVA, Fernando. Entrevista: Fernando Saraiva [mai. 2018]. Entrevistador: Carlos Augusto Tavares Junior. Rio de Janeiro: Globosat, 2018. 1 arquivo. WAV (14,5 min.).

SARTORELO, João Jair. Entrevista: Prof. João Jair Sartorelo [nov. 2015]. Entrevistador: Carlos Augusto Tavares Junior. Campo Grande: UFMS, 2015. 1 arquivo. WAV (6,1 min.).

SILVA, Daniel Vieira da. Entrevista: Daniel Vieira da Silva [out. 2017]. Entrevistador: Carlos Augusto Tavares Junior. Braga: Rádio Universitária do Minho, 2017. 1 arquivo .WAV (16,4 min.).

SILVEIRA, Nathália Ely. Entrevista: Nathália Ely Silveira [set. 2018]. Entrevistador: Carlos Augusto Tavares Junior. Porto Alegre: Charrua Clube, 2018. 1 arquivo. WAV (12,4 min.).

TAMBUCCI, Pacoal Luiz. Entrevista: Prof. Dr. Pascoal Luiz Tambucci [mar. 2016]. Entrevistador: Carlos Augusto Tavares Junior. São Paulo: EEFE/CEPE/USP, 2016. 1 arquivo. WAV (14,4 min.).

TOURAL BRAN, Carlos. Entrevista: Prof. Dr. Carlos Toural Bran [dez. 2017]. Entrevistador: Carlos Augusto Tavares Junior. Santiago de Compostela: Facultad de Comunicación, 2017. 1 arquivo. AAC (4,1 min.). 